\title{
O CONCEITO DE PESSOA MORAL COMO CRITÉRIO PARA ANÁLISE DO ABORTO PROVOCADO: CONSIDERAÇÕES INTERDISCIPLINARES
}

\author{
Dissertação apresentada à Faculdade de Direito da \\ Universidade de São Paulo para obtenção do título \\ de mestre pelo Departamento de Filosofia e Teoria \\ Geral do Direito - DFD. \\ Orientadora: Professora Doutora Mara Regina de \\ Oliveira.
}

Faculdade de Direito - FDUSP

São Paulo 
FOLHA DE APROVAÇÃO

Nome: ORTEGA, Luciano Correa

Título: O conceito de pessoa moral como critério para análise do aborto provocado: considerações interdisciplinares

Dissertação apresentada à Faculdade de Direito da Universidade de São Paulo para obtenção do título de mestre em Filosofia do Direito e Teoria Geral do Direito

Orientadora: Professora Doutora Mara Regina de Oliveira

Aprovado em: / /

Banca Examinadora

Prof. Dr.:

Instituição:

Assinatura

Prof. Dr.:

Instituição:

Assinatura

Prof. Dr.:

Instituição: Assinatura 
Aos meus pais, que mesmo sem a oportunidade de estudar, foram exímios educadores, instigando a cada dia nas descobertas e no aprendizado;

À minha irmã, grande amiga;

À Professora Mara Regina de Oliveira que, além de orientar efetivamente nessa caminhada acadêmica, incentivou uma nova forma de raciocínio, mostrando a estreita relação que existe entre a Arte e o Direito;

Aos amigos e colegas do Tribunal de Justiça do Estado de São Paulo, que me acompanharam de modo estimulante no desenvolvimento desse projeto. 


\section{RESUMO}

\section{ORTEGA, Luciano Correa. O conceito de pessoa moral como critério para análise do} aborto provocado: considerações interdisciplinares. Dissertação de Mestrado. Faculdade de Direito, Universidade de São Paulo. São Paulo, 2011.

O presente estudo tem por escopo investigar o conceito de pessoa moral, e as implicações éticas e jurídicas em considerá-lo como critério de análise nas discussões bioéticas referentes ao aborto, afastando-se, desta forma, do parâmetro estrito da vida biológica, que paira sobre os debates. Assim, o trabalho tem por fundamento metodológico uma abordagem interdisciplinar com predomínio do enfoque zetético-jurídico, valendo-se da inserção de filmes referentes ao assunto e da linguagem logopática do cinema como forma de expandir o objeto de conhecimento, o que colabora para a apreensão afetiva de uma questão humana que envolve em seu interior uma decisão pautada por um conflito éticojurídico.

Palavras-chave: pessoa, aborto, moralidade, cinema, relativismo. 


\begin{abstract}
ORTEGA, Luciano Correa. The concept of moral person as a criterion for induced abortion's analysis: interdisciplinary considerations. Dissertation (Master's). Faculty of Law, University of São Paulo. São Paulo, 2011.

This work has the aim of studying the concept of moral person, and its moral and legal implications as considering it as a criterion for analysis in bioethical discussions concerning abortion, deviating, in this way, of the strict parameter of biological life, that hovers upon the pleadings. Thus, this work has as methodological foundation an interdisciplinary approach with predominance of legal-zetetic focus, inserting movies related to this issue and logopatic language of cinema as a means of expanding knowledge matter, which helps us comprehend an affective sense of a human question intrinsically connected to a decision of an ethical-legal conflict.
\end{abstract}

Keywords: person, abortion, morality, cinema, relativism 
Sumário

Introdução

1

CAPÍTULO 1 - INTERDISCIPLINARIDADE E CONHECIMENTO: DIREITO,

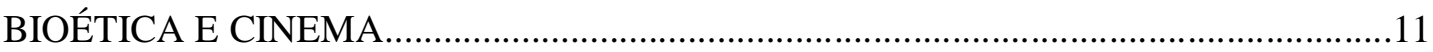

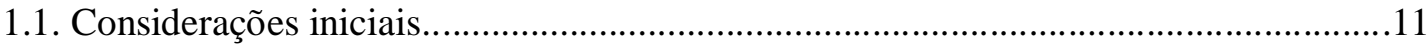

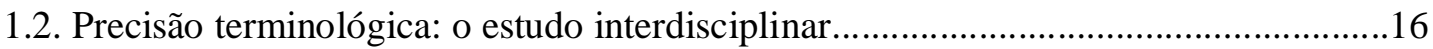

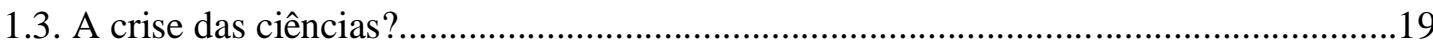

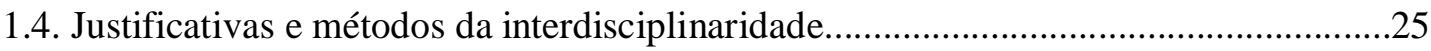

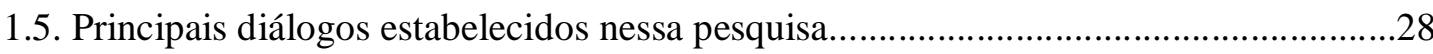

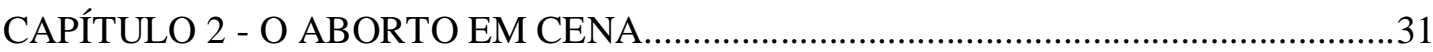

2.1. Apresentação do problema e considerações metodológicas...........................................31

2.2. O aborto provocado e a emergência dos direitos reprodutivos: o cerne da decisão - a

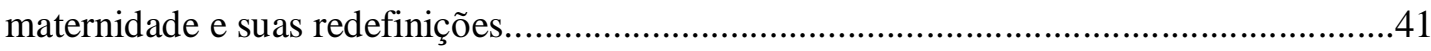

2.3. A cultura do aborto sob o enfoque da teoria pragmático-jurídica da comunicação.......47

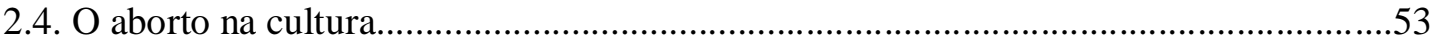

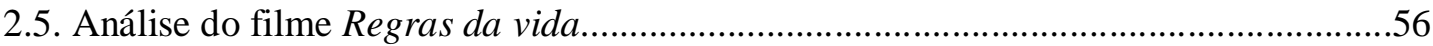

CAPÍTULO 3 - RELATIVISMO E UNIVERSALISMO MORAL: O PROBLEMA DO

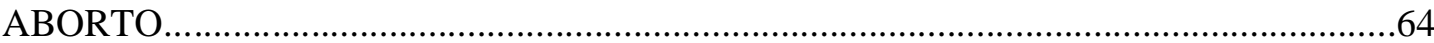

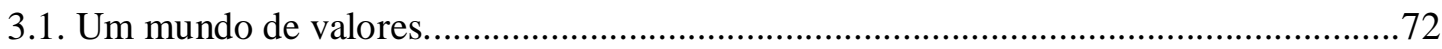

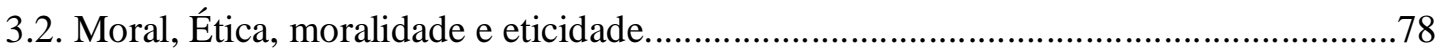

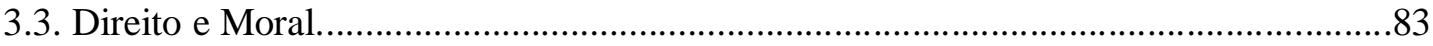

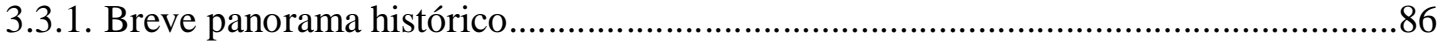

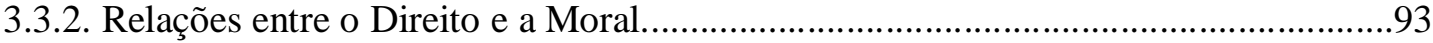




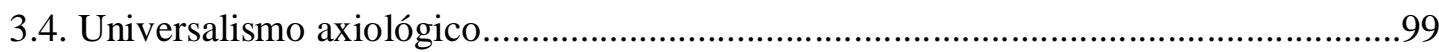

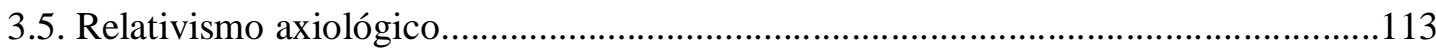

3.6. Análise do filme $O$ segredo de Vera Drake................................................................123

3.7. Análise do filme 4 meses, 3 semanas e 2 dias..............................................................134

CAPÍTULO 4 - A VIDA HUMANA: O HOMEM BIOLÓGICO.....................................143

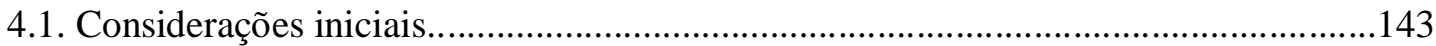

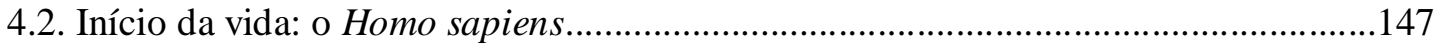

4.2.1. Concepções médico-biológicas sobre o início da vida humana: ...........................149

4.2.2. Concepções biossemiótica e autopoiética sobre o início da vida.............................160

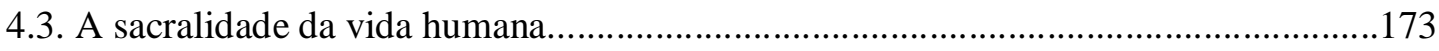

4.4. Silogismos: a argumentação lógica em defesa da vida............................................187

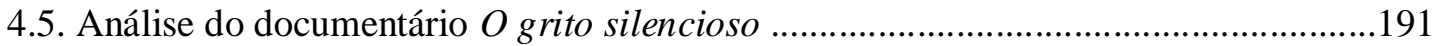

CAPÍTULO 5 - O HOMEM PÓS-ONTOLÓGICO: A PESSOA.......................................203

5.1. O conceito de pessoa: a perspectiva de Joseph Fletcher...........................................208

5.2. O Conceito de Pessoa em John Locke.......................................................................222

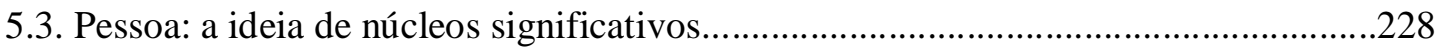

5.4. O conceito normativista de pessoa na Teoria Pura do Direito de Hans Kelsen...........231

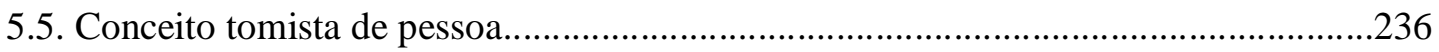

5.6. Michael Tooley e o conceito de pessoa: a teoria dos desejos e o direito à vida..........241

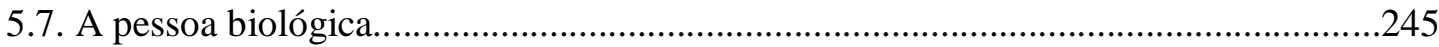

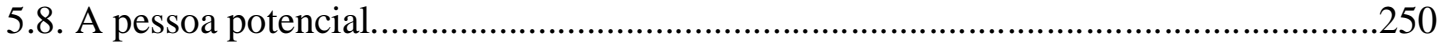

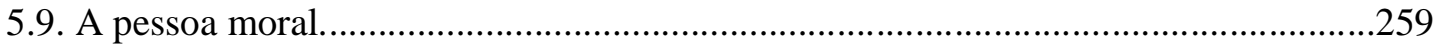

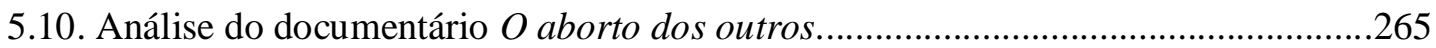

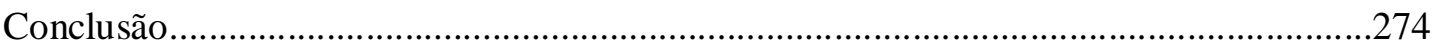

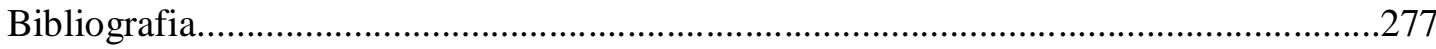




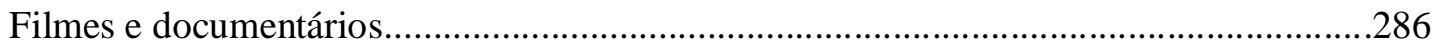

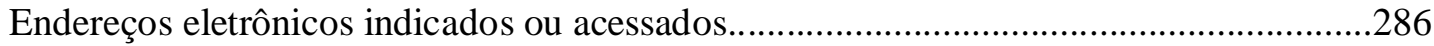




\section{INTRODUÇÃO}

O Direito, inserido no universo da cultura, tem por fundamento o conceito de pessoa. Esta, em sua dignidade essencial, constitui o vértice axiológico daquele, sem o qual perdem sentido todas as relações jurídicas.

Entretanto, a análise do fenômeno jurídico sob uma perspectiva histórica permite verificar que nem sempre todos os homens foram considerados pessoas. Deveras houve épocas em que a alguns se assegurava a titularidade de direitos e obrigações, enquanto outros eram equiparados à res, instrumentalizados como objetos de direito ${ }^{1}$ : observa-se uma nítida separação entre pessoas e coisas, uma summa divisio entre duas categorias jurídicas.

No entanto, à medida que se desenvolve o conceito de pessoa, há uma paulatina equiparação entre homem e sujeito moral, até a identificação de ambos, agora reciprocamente ligados e indissociáveis.

Nesse sentido, cumpre salientar que, no pensamento jurídico grego, predominando a noção geral e abstrata, recorre-se às ideias de prósopa e hypóstase ${ }^{2}$. Numa segunda etapa da construção do conceito de pessoa, verifica-se, com Boécio e São Tomás de Aquino, a avaliação substancialista de pessoa, entendida como naturae individua substantia. A síntese dessa visão encontra-se no adágio tomista ubi homo sapiens ibi persona, o que inspiraria o desenvolvimento da concepção realista do agente moral.

Seguindo a evolução do conceito, sob a influência kantiana, o homem aparece como o fim em si mesmo. Às coisas, atribui-se um preço (Preis); ao homem, dignidade (Würde). Nota-se, aqui, uma separação entre sujeito e objeto, e

será com Kant e Hegel que a relação ‘sujeito-objeto’ será colocada em termos de oposição, de modo a conferir uma heterogeneidade absoluta entre estas duas realidades. Com efeito, a modernidade, que tomaria a subjetividade humana como ponto de partida de todas as suas elaborações, vai radicalizar a separação entre o 'sujeito' e o 'objeto'. Aquilo que era uma distinção torna-se uma oposição. Nenhuma confusão será mais admitida entre estes dois termos e se

\footnotetext{
${ }^{1}$ Entretanto, os escravos e servos eram reconhecidos como humanos, embora privados de todos os direitos; sujeitavam-se ao alvedrio dos senhores, como outros animais e coisas. Eram, de fato, objetos de direito. Vale salientar, ainda, que a expressão "pessoal moral" não indica, na dissertação, o mesmo que pessoa jurídica.

2 Para melhor compreensão dos termos, remetemos o leitor ao tópico denominado "Conceito tomista de pessoa" (infra, p.242).
} 
assentará a validade efetiva dos direitos do homem na qualidade radical desta dividão do real ${ }^{3}$.

Mas não há uma instrumentalização do sujeito, nos moldes que ocorrera em outra época. Numa quarta etapa da elaboração do conceito de pessoa, enxerga-se o homem como o único capaz de dirigir sua vida em função de suas preferências valorativas. Por fim, vê-se a abordagem do sujeito moral em consonância com as doutrinas existencialistas ${ }^{4}$.

Uma outra corrente que pode ser analisada nesse percurso é a que considera a pessoa como sendo uma categoria construída, uma "construção humana" - assim como outros conceitos o são, tal como a própria norma, cuja existência no mundo concreto jamais pode ser observada. Kelsen ${ }^{5}$ é um dos autores que aceitam a "ficção" da pessoa natural, que seria, na verdade, tão normativa como uma "pessoa jurídica". Tal proposta é tida como polêmica no quadro dos estudos do Direito.

Ao fim de todo esse desenvolvimento conceitual, consagrou-se a menção à pessoa humana, sem possibilidade de cisão entre o biológico e o agente moral, ao ponto de muitos autores associarem o princípio da personalidade ao início da vida.

Ocorre que novos problemas bioéticos surgiram com o domínio de técnicas antes impensáveis, que permitiram a manipulação do próprio material genético, o prolongamento artificial da vida ou mesmo sua interrupção, o conhecimento de técnicas de diagnóstico pré-natal que tornaram o feto verdadeiro paciente, ao mesmo tempo em que possibilitaram a detecção de enfermidades incuráveis e incompatíveis com a vida extrauterina. Assim, vieram a lume outras discussões acerca do conceito de pessoa, com dissociação do ser meramente biológico (vida humana) e do ser ontológico (agente moral).

Essa separação entre individualidade genética e ontológica, tomada como critério necessário para alguns na análise das questões bioéticas, acabou sendo rechaçada por outros, que a consideraram uma tentativa de romper a "unitotalidade" do homem, sendo algo arbitrário. Instala-se a polêmica, e a definição de pessoa torna-se o centro dos

\footnotetext{
${ }^{3}$ Tradução nossa. No original, "Ce sera avec Kant et Hegel que la relation 'sujet-objet' será posée en termes d'opposition, de façon à assurer une hétérogénéité absolue entre ces deux realités. En effet, la modernité, qui prendra la subjectivité humaine comme point de départ de touts ses élaborations, va radicaliser la séparation entre le 'sujet' et le 'objet'. Ce qui n'était qu'une distinction deviendra une opposition. Nulle confusion ne será désormais admissible entre ces deux termes car il en va de la validité effective des droits de l'homme dans le caractère radical de cette bipartition du réel". ANDORNO, Roberto. La distinction juridique entre les personnes et les choses à l'épreuve des procréations artificielles. Paris: L. G. D. J., t. 263, 1996.

${ }^{4}$ COMPARATO, Fábio Konder. A afirmação histórica dos direitos humanos. São Paulo: Saraiva, 2001.

${ }^{5}$ ANDORNO, Roberto. Op. cit., p. 147. Assim Savigny, Glucke, Marcadé. Ainda de acordo com a teoria da ficção, cf. KELSEN, Hans. Teoria Pura do Direito. São Paulo: Martins Fontes, 2003, pp. 188-213.
} 
debates, e pode ser tomada, também, como uma construção linguística, um conceito elaborado.

Se para alguns há uma identificação entre o início da vida e o processo de "ser pessoa", considerando-se o indivíduo um continuum vital, para outros uma realidade não se reduz à outra.

Roberto Andorno, ao debruçar-se sobre o assunto, fala em uma "dessubstancialização" progressiva sofrida pelo conceito de pessoa nos últimos séculos, tornado abstrato e formal, nos moldes do reducionismo de Descartes, com a ruptura entre raison e corps (res cogitans e res extensa), o que possibilitou as manipulações reificadoras do humano numa era biotecnológica. Para o autor, o jurista não deve se contentar com essa visão puramente formalista, como máscara $^{6}$, papel ou função; ao contrário, deve se interrogar a respeito da substância atrás da máscara, sobre seu ser e dever-ser, sua verdade e seu valor.

Por outro lado, autores há que vislumbram uma diferença essencial entre pertencer à espécie Homo sapiens e ser uma pessoa. Peter Singer, em suas obras ${ }^{7}$, destaca sempre a distinção entre se ter um código genético humano e ser um sujeito moral, que é o que realmente importa. Não basta, portanto, o aspecto biológico, o organismo. Será pessoa o ente capaz de apresentar consciência e de entender-se numa linha contínua, tendo noção de passado e futuro.

Nesse sentido, já em Locke, na obra Ensaio sobre o entendimento humano ${ }^{8}$, definia-se pessoa como um ser pensante e inteligente, dotado de razão e reflexão, que pode ver-se como tal em tempos e lugares diferentes. A propósito, Joseph Fletcher ${ }^{9}$, teólogo protestante estudioso de assuntos referentes à Bioética, fez uma relação de alguns "indicadores de humanidade" (indicators of humanhood), listando características propriamente humanas, como autoconsciência, autocontrole, senso de futuro e passado, capacidade de relacionar-se com os outros, comunicação e curiosidade; com isso, na verdade, classificava atributos da "pessoa".

\footnotetext{
${ }^{6}$ Em latim, persona significava a máscara que os atores usavam na antiguidade, fazendo ressoar forte a voz (per suonare). Daí a ideia de a pessoa ser um papel desempenhado pelo indivíduo. Segundo Fábio Konder Comparato, "A oposição entre máscara teatral (papel de cada indivíduo na vida social) e essência individual de cada ser humano - que veio a ser denominada com o termo personalidade - foi, em seguida, longamente discutida e aprofundada pelos estoicos. (COMPARATO, Fábio Konder. A afirmação histórica dos direitos humanos. São Paulo: Saraiva, 2001, p.15)

${ }^{7}$ A distinção entre ser um sujeito moral e ter código genético está presente em obras como Ética Prática. São Paulo: Martins Fontes, 2002 e Libertação Animal. São Paulo: Lugano, 2004.

${ }^{8}$ LOCKE, John. Ensaio sobre o entendimento humano. Buenos Aires: Fondo de Cultura Económica, 1956.

${ }^{9}$ FLETCHER, Joseph. Humanhood: essays in biomedical ethics. New York: Prometheus Books,1979.
} 
É preciso não esquecer que os gregos já faziam uma distinção valiosa: ao se referirem à 'vida', utilizavam dois vocábulos distintos: zoê, referindo-se à vida orgânica, comum a todos os animais, e bios, designando a vida propriamente humana, que compreende o agir, o pensar e o contemplar. ${ }^{10} \mathrm{O}$ homem é um ser biológico, mas também é um ser cultural, como lembram Marco Segre e Cláudio Cohen. ${ }^{11}$ Assevera Battista Mondin, nesta linha de raciocínio, que "o homem não é somente um produto da natureza e nem apenas da história, mas é constituído, em parte pela natureza e em parte pela história, é o amálgama (sínodo) entre a natureza e a história, é obra da cultura"12.

O direito à vida, neste entremeio, acaba ganhando uma dimensão mais ampla, que transborda a mera análise legal. Como pondera Jon York, não é suficiente no estudo do direito à vida que sua análise fique restrita ao campo da lei, da crítica legal; ciência política, exposição filosófica e outros sistemas de pensamento são essenciais ${ }^{13}$. Destaca-se, assim, a importância da análise de um conceito moral de pessoa.

Alguns autores, por seu turno, chegam a falar em um "conceito pós-moderno" de personalidade, entendendo ser a pessoa o sujeito do domínio moral. ${ }^{14}$ Nesse sentido, $\mathrm{H}$. Tristam Engelhardt escreve acerca de uma moralidade secular canônica que cede lugar a uma perspectiva filosófica pós-moderna. Para o autor,

o fracasso do moderno projeto filosófico moral nos leva de volta ao politeísmo e ao ceticismo dos tempos antigos, com a lembrança do monoteísmo filosófico e da fé que moldaram o Ocidente. Existe uma sensação de perda. Contra a

${ }^{10}$ COMPARATO, Fábio Konder. Ética: Direito, Moral e Religião no mundo moderno. São Paulo, Companhia das letras, 2006, p. 694. Uma análise bem aprofundada sobre os termos zoè e bios, o primeiro referindo-se ao simples viver (mere living) e o segundo, ao aspecto histórico e cultural, é realizada por Mark Olssen, no capítulo 2, entitulado "Politics and the philosophy of life: Towards a normative framework", da obra The right to life and the value of life: Orientations in Law, Politics and Ethics. Great Britain: Ashgate, 2010, pp. 39-63. O autor aborda a história da Filosofia da vida (Lebensphilosophie), e a concepção de estudiosos do porte de Spinoza, Hume, Nietzche, Bergson, Foucault e Deleuze.

${ }^{11}$ SEGRE, Marco; COHEN, Cláudio. Bioética, São Paulo: Edusp, 1999, pp.12-3.

${ }^{12}$ MONDIN, Battista. Definição filosófica de pessoa. Bauru: Edusc, 1998, pp. 14-15. Continua o autor, dizendo: "diversamente dos outros seres vivos, cujo ser é inteiramente produzido, pré-fabricado pela natureza, o homem é em grande medida artífice de si mesmo. Enquanto as plantas e os animais sofrem, no ambiente natural em que se encontram, o homem é capaz de cultivá-lo e de transformá-lo profundamente, adequando-o às próprias necessidades". E mais: "a cultura não é uma roupa que se vista ou se dispa ao próprio prazer, não é qualquer coisa acidental e secundária, mas é um elemento constitutivo da essência do homem, ela faz parte da natureza humana. Sem a cultura não é possível existir nem a pessoa individualmente, nem o grupo social".

${ }^{13}$ YORK, Jon. The right to life and the value of life: Orientations in Law, Politics and Ethics. Great Britain: Ashgate, 2010, p. 1.

${ }^{14}$ RICH, Ben A. Postmodern personhood: a matter of consciousness. In: Bioethics, v. 11, no 3, 1997, p. 206. Segundo o autor, "o conceito de pessoa é integral ao discurso bioético porque pessoas são o próprio objeto do domínio moral" (tradução nossa). No original: "the concept of person is integral to bioethical discourse because persons are proper subject of the moral domain". 
lembrança de uma unidade e comunidade procurada, se nunca foi alcançada, existe uma diversidade de visões morais e bioéticas essenciais que não se submeterá a uma só interpretação essencial. Este é o preço da pós-modernidade e da visão multicultural e multiperspectiva por ela imposta. ${ }^{15}$

Mas nosso estudo do conceito de pessoa na Filosofia do Direito, em especial na Bioética, deve ser delimitado, o que possibilitará o aprofundamento - necessário - das discussões.

Nesse passo, se inúmeras são as questões bioéticas que envolvem o começo e o fim da vida humana, poucas ensejam tantos debates como o aborto, que suscita posicionamentos românticos e extremados - o que nos conduz ao estudo dessa problemática tendo por parâmetro o conceito de pessoa. Assim, este será nosso foco. Esta é a premissa de investigação: averiguar a aplicação da concepção de agente moral como critério para análise dos dilemas que envolvem o aborto, tomando por temas a Bioética, o cinema e a Filosofia do Direito. Dessa maneira, o conceito de pessoa poderia servir como um parâmetro para decisão, no caso do aborto, permitindo, assim, a interrupção da gravidez? E como tomar a pessoa como critério se o conceito pode ser linguisticamente manipulado?

Como salienta Jeff MacMahan,

há muitas razões para que o aborto permaneça sendo uma das controvérsias mais intratáveis de todas as questões morais. No entanto, a razão principal é a de que o estatuto moral e metafísico de embriões e fetos humanos está amortalhado na escuridão. Em alguns aspectos, esses seres são similares a você e a mim; em outros, profundamente diferentes ${ }^{16}$.

$\mathrm{O}$ ponto de partida da pesquisa é, pois, eminentemente zetético ${ }^{17}$ e dá especial destaque aos problemas hermenêuticos que estão às voltas nos debates envolvendo a

${ }^{15}$ ENGELHARDT, H. Tristram. Fundamentos da Bioética. São Paulo: Loyola, 2004, pp. 34-39.

${ }^{16}$ MACMAHAN, Jeff. A ética no ato de matar. Porto Alegre: Artmed, 2011, p. 15.

${ }^{17}$ FERRAZ Jr. Tércio Sampaio. Introdução ao estudo do Direito: técnica, decisão, dominação. São Paulo: Atlas, 1994, p. 41. É possível estabecer a distinção entre os enfoques zetético e dogmático, que não são separáveis em absoluto, mas apenas predominam em determinado contexto. Assim, comparativamente, na lição de Tércio, "o enfoque dogmático releva o ato de opinar e ressalva algumas opiniões. O zetético, ao contrário, desintegra, dissolve as opiniões, pondo-as em dúvida. Questões zetéticas têm uma função especulativa explícita e são infinitas. Questões dogmáticas têm uma função diretiva explícita e são finitas. Nas primeiras, o problema tematizado é configurado como um ser (que é algo?). Nas segundas, a situação nelas captada se configura como um dever-ser (como deve-ser algo?). Por isso, o enfoque zetético visa a saber o que é uma coisa. Já o enfoque dogmático se preocupa em possibilitar uma decisão e orientar a ação". 
interrupção da gravidez. Faz-se necessário destacar que não se trata de uma abordagem do tema que abranja os direitos reprodutivos, aspectos sociológicos, facetas psicológicas, ou que tenha por núcleo a questão médica de maneira estrita. Todas essas aproximações da questão são possíveis, mas nosso estudo, mesmo que interdisciplinar, privilegia, sob o enfoque da Filosofia do Direito, uma análise que tenha por parâmetro o status moral do embrião e do feto (como pessoa ou não), além das muitas repercussões que podem surgir no mundo do Direito, comparando-as a aspectos da dogmática jurídica, quando pertinente.

E a distinção entre vida humana e vida humanizada é crucial para a tomada de decisões quanto à interrupção da gravidez. $\mathrm{O}$ fato de pôr fim à gestação envolve inúmeros aspectos, que não confluem unicamente para a natureza biológica humana do feto (vida humana).

Assevera H. Tristam Engelhardt que

o início da vida biológica humana não é o início da vida de uma pessoa como agente moral. Em ontogenia humana vivem-se meses de vida biológica antes que haja suficiente prova de vida da mente - anos se passam antes que existam provas da vida de uma pessoa como agente moral. Como resultado, a condição moral dos zigotos, embriões, fetos e até bebês é problemática para a moralidade secular geral ${ }^{18}$.

Portanto, esse quadro que esboçamos merece estudo detido acerca do que se entende, na Filosofia do Direito, por "pessoa". Pretendemos, com isso, analisar se é possível utilizar o conceito como um critério válido para verificar a possibilidade do abortamento. E, como já destacamos, a pessoa não é uma realidade empírica, mas um conceito referencial, uma construção que utilizamos como premissa para abordagem da questão moral. Se não há pessoa como realidade em si, sendo sempre necessário o substrato biológico, também é equivocada a equiparação de ambos os termos. Essa análise comporá o último capítulo.

Entretanto, primeiramente, antes dessa apreciação, é necessário estabelecer as bases metodológicas fundamentais dessa pesquisa, o que será realizado nos dois capítulos iniciais, dedicados ao estudo do fundamento da possibilidade das relações interdisciplinares e às conceituações basilares sobre a linguagem do cinema, com alguns conceitos-imagem. Como salienta Julio Cabrera, "esta experiência instauradora e

\footnotetext{
${ }^{18}$ ENGELHARDT, H. Tristram. Fundamentos da Bioética. São Paulo: Loyola, 2004, p. 308.
} 
emocionalmente impactante, os conceitos-imagem afirmam algo sobre o mundo com pretensões de verdade e de universalidade". ${ }^{19}$ O cinema é uma composição que se expressa em uma linguagem própria, capaz de abranger outras formas de manifestação do pensamento, e que propicia uma reflexão contundente sobre a própria realidade - sem que se confunda com ela; além disso, estabelece os pilares da teoria pragmático-jurídica da comunicação normativa, o que compõe um enfoque zetético. De fato, ao averiguar se o conceito de pessoa é mais apropriado para ser tomado como base para as discussões sobre o aborto (e, portanto, mais adequado ao viés relativista), em contraposição ao absolutismo que se verifica com a sacralização da vida biológica, tem-se em destaque o caráter dialógico do discurso ${ }^{20}$, e considerações hermenêuticas de grande importância, que muitas vezes são preteridas nos debates sobre o aborto. $\mathrm{O}$ fato de a pessoa representar, antes de tudo, um conceito dá azo às inúmeras interpretações, que não se compartimentalizam em soluções definitivas ou respostas corretas à questão sob análise. Também vale ressaltar que é o diálogo que inspira a Bioética.

Ademais, é plenamente possível neste trabalho de Filosofia do Direito utilizar a análise de filmes/documentários que trazem alguns dos dilemas presentes no momento da tomada de decisão. As apreciações dos filmes selecionados serão realizadas ao final dos capítulos segundo, terceiro, quarto e quinto.

Desta maneira, urge salientar que a eleição das películas não foi aleatória. Escolhemos alguns filmes que revelam facetas diferentes do aborto e que possam ter interesse nas discussões travadas. Assim, analisaremos um curto documentário produzido por Bernard Nathanson, intitulado $O$ grito silencioso (The silent scream), que trata do assunto de um modo que poderíamos denominar atávico, nas palavras de Célia WolfDevine $^{21}$.

Outros dois filmes servirão de importante apoio para ilustração das discussões atinentes à moralidade: $O$ segredo de Vera Drake (Vera Drake), que aborda de modo

\footnotetext{
${ }^{19}$ CABRERA, Julio. O cinema pensa: uma introdução à Filosofia do Direito através dos filmes. Rio de Janeiro: Rocco, 2006, p. 23.

${ }^{20}$ FERRAZ Jr. Tércio Sampaio. Teoria da norma jurídica. Rio de Janeiro: Forense, 1978, pp.20-21. O caráter dialógico relaciona-se à estrutura do discurso racional ou fundamentante, ou seja, que se submete ao dever de prova. N'outros termos, parte-se da premissa, nesse tipo estrutural de discurso, que todo ato de falar pode ser colocado em dúvida, estabelecendo-se entre orador e ouvinte "diálogos parciais". Além disso, a ação linguística primária (como um ponto de partida), não pode ser atacada pelo ouvinte e, finalmente, o orador também não poderá modificar suas ações linguísticas primárias. Nos dizeres do autor, "a dialogicidade, como se vê, não pressupõe o princípio do terceiro excluído que exigiria, no caso, que todo ato de falar fosse ou atacável ou inatacável, o que feriria a primeira regra".

${ }^{21}$ TOOLEY, Michael; WOLF-DEVINE, Célia; DEVINE, Philip E.; JAGGAR, Alison M. Abortion: three perspectives. New York: Oxford University Press, 2009, pp. 68-69.
} 
ficcional um dos enfoques da real clandestinidade e ilegalidade das práticas abortivas, e o filme romeno 4 meses, 3 semanas e 2 dias (4 luni, 3 saptamâni si 2 zile).

O documentário $O$ aborto dos outros, que revela o problema de saúde pública presente na temática, acrescentará à discussão depoimentos de mulheres que se submeteram ao aborto, evidenciando as inúmeras faces do problema.

Finalmente, vale a pena analisar o filme Regras da vida (The Cider House Rules), que aborda, entre outras questões, a rejeição que envolve uma gravidez não desejada. Por certo, há interconexões entre as obras cinematográficas, mas o enfoque de cada uma é ligeiramente distinta. Não se ignora, também, a existência de outros filmes que tratam do aborto, como Uma história severina, de Eliane Brum; por razões metodológicas, restringimo-nos aos filmes acima mencionados.

Após a sedimentação metodológica, é mister dedicarmos algumas páginas deste trabalho ao estudo do que se denomina "diversidade moral". A dificuldade reside não na constatação de posicionamentos múltiplos, mas na eventual prevalência de uma das abordagens, o que delineia o velho debate entre universalismo e relativismo axiológicos. Neste ponto, filósofos como Kant e Nietzsche e teóricos do Direito como Kelsen auxiliarão na compreensão dessas discussões, que remetem às relações que podem existir entre o Direito e a Moral. Tal análise compõe o capítulo terceiro.

No entanto, é necessário salientar que o próprio embate ético entre universalismo e relativismo ensejaria discussão apartada, um estudo próprio - dada a complexidade do tema. Com isso, assentamos que trataremos do assunto em linhas gerais, o suficiente para acrescentarmos ao trabalho aqui desenvolvido algumas observações que são pertinentes, sem a pretensão de esgotar o tema.

A clandestinidade das práticas abortivas parece deveras uma rejeição da autoridade que a coíbe. Apesar da compreensão do vetor deôntico de proibição, a norma é muitas vezes desobedecida, e o cinema pode ser instrumento hábil para expor a relação entre o Estado (através das suas normas) e os destinatários dessas mensagens.

Percebe-se, pois, a atualidade do tema, bem como as polêmicas que ensejam a definição do conceito de pessoa como ponto de partida para as decisões no âmbito do Direito, mormente no que concerne às questões biotecnológicas e bioéticas, que envolvem início e fim da vida (assim no caso do aborto e da eutanásia), bem como experimentos envolvendo, dentre outros, genoma, células-tronco, screening genético, reprodução assistida. 
Com isso, teremos o suporte para aprofundar as questões atinentes à individualidade genética, no capítulo quarto, e a individualidade ontológica, no capítulo quinto. Num primeiro momento, em torno da individualidade genética, centra-se o estudo do homem biológico, das doutrinas sobre a santidade da vida e da utilização de silogismos que alavancam o valor das vidas embrionária e fetal. Na sequência, ao tratarmos da individualidade ontológica, teremos a possibilidade de avançarmos na pesquisa dos conceitos e atributos da pessoa.

Com base em uma Antropologia filosófica, estabelecem-se caracteres como a liberdade, a autoconsciência, a sociabilidade, a historicidade e a unicidade existencial do ser humano ${ }^{22}$, o que nos leva a algumas questões: é necessária uma redefinição do conceito de pessoa? Essa "dessubstancialização" a que se referiu Andorno remete-nos, de fato, a um retrocesso, a exemplo de outras épocas? Diz o autor:

Tem-se a impressão de que o homem sucumbe em cada época à tentação, mais ou menos manifesta, de submeter seus semelhantes, notadamente os mais fracos, a uma dominação que advém da omnipotência. Com isso se nega, na prática, a dignidade que a civilização ocidental parece reconhecer a todo homem pelo só fato de ser homem. O escravo antigo, o servo da gleba da Idade Média, o operário industrial do século XIX e o cidadão dos Estados totalitários do século XX são exemplos mais marcantes. Neste fim de século, os resultados de um controle total do homem sobre o homem por meio das biotecnologias criam o forte risco de seguir esta mesma linha ${ }^{23}$.

Haveria uma distinção necessária entre vida humana e vida humanizada? Como se insere a dignidade humana em todas essas discussões? De que forma conciliar os avanços das técnicas e o respeito à pessoa? Qual a concepção filosófica de pessoa potencial? Aí se incluirá nosso estudo acerca da abordagem da problemática do aborto tendo por parâmetro o conceito de pessoa.

${ }^{22}$ COMPARATO, Fábio Konder. Fundamento dos Direitos Humanos. In: Revista do instituto de estudos avançados da Universidade de São Paulo, pp. 15-19. Disponível em: http://www.iea.usp.br/textos/comparatodireitoshumanos.pdfv.

${ }^{23}$ Tradução nossa de ANDORNO, Roberto. La distinction juridique entre les personnes et les choses à l'épreuve des procréations artificielles. Paris: L. G. D. J., t. 263, 1996, p. 1. Escreve o autor, no original: "On a l'impression que l'homme succombe à chaque époque à la tentation, plus ou moins manifeste, de soumettre ses semblables, notamment les plus faibles, à une domination qui relève de la toute-puissance. Par là il en vient à nier, dans la pratique, la dignité que la civilisation occidentale semble réconnaître à tout homme du seul fait qu'il est homme. L'esclave antique, le serf de la glèbe du Moyen Age, l'ouvrier industriel du XIX s. et le citoyen des États totalitaires du XX s. en sont les exemples les plus saillants. Dans cette fin de siècle, les dérives d'une maitrise totale de l'homme par l'homme au moyen des biotechnologies risquent fortement de s'inscrire dans cette même ligne." 
Portanto, o foco do estudo é somente o aborto, em que pese a possibilidade de outros temas dos debates bioéticos também serem desenvolvidos com base na definição do termo pessoa. A delimitação deve-se à necessidade de um estudo aprofundado de uma destas questões, que tanta controvérsia suscita.

Passemos ao estudo. 


\section{CAPÍTULO 1: INTERDISCIPLINARIDADE E CONHECIMENTO: DIREITO, BIOÉTICA E CINEMA}

\subsection{Considerações iniciais}

O conhecimento dirigido a determinado objeto quase sempre privilegia um dos enfoques possíveis de análise. Deveras, parece impossível captar a totalidade de aspectos de um ser, de uma coisa, de um fenômeno, de uma relação humana. Daí advêm a particularização crescente e o corte metodológico, que inspiram a existência de uma variada gama de "áreas do saber" e disciplinas, pugnando cada um deles por um específico campo de atuação, chegando ao limite dos especialistas, conhecedores em profundidade de uma pequena extensão.

Os reflexos dessa maneira especificadora de abordagem alcançaram todas as áreas do conhecimento, grassando receptividade, também, nas denominadas Ciências Humanas.

Porém, como ensina Lídia Reis de Almeida Prado,

a ênfase dada ao método científico e ao pensamento racional, estendida para as ciências ditas humanas, gerou uma dificuldade de compreensão do mundo. $\mathrm{O}$ homem, que aprendeu a dissecar o objeto de sua observação para entendê-lo, tornou-se especialista em partes, mas ignorante em relação à totalidade ${ }^{24}$.

Podemos encontrar passos dessa especialização já no século XII, com a abertura aos conhecimentos profanos, que ganhavam mais e mais espaço entre clero e leigos. Como ensinam Arminda Eugênia Marques Campos e Roberto S. Bartholo Jr.,

\footnotetext{
a tendência à especialização e à profissionalização cresceria nas universidades, corporações formadas justamente por pessoas caracterizadas por seus vínculos com o estudo, seja como professores seja como estudantes. A vida intelectual tornava-se um ofício ${ }^{25}$.
}

\footnotetext{
${ }^{24}$ PRADO, Lídia Reis de Almeida. O juiz e a emoção: aspectos da lógica da decisão judicial. Campinas: Millennium, 2008, p. 7.

${ }^{25}$ CAMPOS, Arminda Eugênia Marques; BARTHOLO Jr, Roberto S. O que é um intelectual? In: BURSZTYN, Marcel (Org.). Ciência, Ética e sustentabilidade: desafios ao novo século. São Paulo: Cortez, 2001, pp. 27-28. Destacam os autores que "o reconhecimento da condição de especialistas ficava explícito, por exemplo, quando se buscava o conjunto de doutores ou alguns entre eles, a fim de obter sua opinião - tida como fundada, como qualificada - sobre um determinado assunto. Isso acontecia em relação aos diversos cursos universitários - direito canônico ou romano, medicina, artes ou teologia. Nesse último
} 
Não poderia ser diferente no que concerne ao Direito, em que sob o gume afiado da separação, inúmeras disciplinas surgiram, reclamando um estatuto acadêmico próprio. Ainda assim, amparando o discurso da divisão estava a ideia da unicidade do fenômeno jurídico, que estaria sendo partilhado para facilitar o estudo - o que foi levado a sério nas grades curriculares de universidades. A divisão ensejou, também, a formação dos especialistas, ávidos e dispostos a dissecarem as veias de determinada área do saber jurídico.

A este respeito, destaca Tércio Sampaio Ferraz Jr. que

nos dias atuais, quando se fala em Ciência do Direito, no sentido do estudo que se processa nas Faculdades de Direito, há uma tendência em identificá-la com um tipo de produção técnica, destinada apenas a atender às necessidades do profissional (o juiz, o advogado, o promotor) no desempenho imediato de suas funções. Na verdade, nos últimos cem anos, o jurista teórico, pela sua formação universitária, foi sendo conduzido a esse tipo de especialização fechada e formalista $^{26}$.

Ocorre que a separação sedimentou uma rígida barreira, de modo a intimidar uma reaproximação das espécies analisadas com afinco por cada um dos ramos do saber jurídico, potencializando uma falta de comunicação, ou uma comunicação polifônica, quando não afônica.

Mais ainda: o que deveria ser unidade e totalidade permaneceu - salvo raras exceções de projetos inovadores - membros sem corpo, ou corpo desmembrado, que desta forma já não mais pode ser considerado algo inteiro. E os reflexos deste esfacelamento são nítidos, seja nas dificuldades de aprendizado calcadas nessa forma dialógica inovadora, seja na resistência à própria aceitação de alguns diálogos que são propostos nessa linha de pesquisa. Mas, como se pretende deixar assentado, trata-se de óbices que podem ser transpostos, bastando uma pequena disposição para tanto, uma abertura ao novo.

domínio, a transformação foi mais notável, uma vez que o corpo de mestres em teologia passou a ser reconhecido na Igreja como tendo autoridade para elaborar doutrina em matéria de fé, o que deixava de ser exclusividade dos concílios. Os universitários eram reconhecidos como tendo valor e uma função específicos para pelo menos parte da sociedade, em razão de seu conhecimento, de sua qualificação".

${ }^{26}$ FERRAZ Jr. Tércio Sampaio. Introdução ao estudo do Direito: técnica, decisão, dominação. São Paulo: Atlas, 1994, pp. 48-49. 
Enfim, esse pensamento de delimitação, se por um lado propicia um avanço vertical de cognição, por outro, ao setorizar e dilacerar o objeto de estudo, pode negligenciar outros elementos, também relevantes para compreensão e para as conclusões da ciência.

Vale ressaltar que o esquecimento desses outros aspectos ${ }^{27}$, levado ao extremo, é mal que leva a falácias, distorções e, por fim, ao empobrecimento daquilo que se perscruta.

No século XVIII, por exemplo, "indica-se a razão como critério de conhecimento e a lógica formal como sustentáculo da objetividade. As dúvidas precisam ser comprovadas, testadas, sequenciadas, avaliadas. Quanto mais se disseca a parte, melhor se conhece" ${ }^{28}$.

Nesse diapasão, como uma resposta à segregação do saber, aparecem inúmeras análises pautadas pelo diálogo, por uma verdadeira conversação sobre aquilo que se estuda, numa abertura às contribuições que cada ramo do conhecimento pode dar. É o que ocorre com a Bioética e o Direito.

As questões humanas subjacentes a ambos clamam por estudos que abranjam diversas possibilidades, tomando por balizas um esforço conjunto que, antes de separar, aproxima aquilo que é afim; antes de dividir e compartimentalizar, adiciona e amplia a visão sobre os debates.

Depois de anos de afastamento e especificação dos objetos de estudo, é chegada a hora de uma reaproximação. Nisso consiste um dos grandes méritos do olhar interdisciplinar.

Pode-se afirmar que as possibilidades são infinitas, e as aproximações realizadas pelos estudiosos variarão conforme o interesse nas ciências, a curiosidade que os move em direção aos experimentos de interconexão. Daí se defender que o pesquisador que se interessa por esta forma de estudo

precisa antes de mais nada assumir um sério compromisso com a erudição, e com a erudição em múltiplas direções. Buscar o conhecimento, uma das atitudes

\footnotetext{
${ }^{27}$ Vale salientar, neste ponto, a inexata compreensão da obra de Hans Kelsen, que destaca nas páginas iniciais o postulado da pureza metodológica da ciência do Direito. Ora, não é o Direito que é puro; isto reconhece o autor, tanto que admite haver uma infinidade de outras ciências que o tomam como objeto de estudo. Nas palavras de Kelsen, "quando a si própria se designa como "pura" teoria do Direito, isto significa que ela se propõe garantir um conhecimento apenas dirigido ao Direito e excluir deste conhecimento tudo quanto não pertença ao seu objeto, tudo quanto não se possa, rigorosamente, determinar como Direito. Quer isto dizer que ela pretende libertar a ciência jurídica de todos os elementos que lhe são estranhos. Esse é o seu princípio metodológico fundamental" (KELSEN, Hans. Teoria Pura do Direito. São Paulo: Martins Fontes, 2009, p.1).

${ }^{28}$ FAZENDA, Ivani C. Arantes. Interdisciplinaridade: história, teoria e pesquisa. Campinas: Papirus, 2010, p.16.
} 
básicas a serem desenvolvidas em quem pretende empreender um projeto interdisciplinar, só pode ser entendido no seu exercício efetivo ${ }^{29}$.

Não se trata de erudição num sentido de pedantismo. Aqui o vocábulo pretende significar o interesse e a busca pelas composições entre os ramos do conhecimento, e isto só é possível se tal procura for dirigida por uma real afeição àquilo que se aprofunda.

Mas nota-se também o revés: há, por outro lado, certa resistência aos estudos que se pautam pela interdisciplinaridade - o que, por vezes, não passa de uma pré-conceituação sem fundamento ou mesmo desconhecimento do que se chama de interdisciplinaridade, que não funciona de modo arbitrário ou aleatório, como se cada ramo do conhecimento preceituasse o que bem entendesse.

Há critérios de afinidade inegáveis entre determinadas ciências, e isso possibilita a convergência de vozes, as múltiplas opiniões e ponderações desse pensar em conjunto.

A relutância talvez advenha mesmo é da dificuldade de olhar o outro, de aceitar aquilo que é dito e, de repente, de aprimorar o pensamento sobre as conclusões que se tinham por certas e inabaláveis. Dessa postura impassível ao diálogo não se podem colher bons frutos. Aliás, por vezes só o conhecimento da árvore é que possibilita uma boa colheita, numa postura que preza por um olhar amplo e global da questão a ser analisada.

Como salienta Ivani C. Arantes Fazenda,

\footnotetext{
o homem, por não estar só no mundo, por possuir uma necessidade essencial de se comunicar, de se relacionar, tem na palavra sua condição primeira de encontro com o outro. Uma das formas mais completas de se estabelecer essa relação eu-outro é a leitura, pois com ela é possível conhecer-se o outro em mim, e eu no outro, já que minha intenção ao ler é captar a linguagem do outro para meu cultivo próprio ${ }^{30}$.
}

Hilton Japiassu enumera uma série de obstáculos ao conhecimento interdisciplinar. Citando G. Gusdorf, refere-se aos obstáculos epistemológicos (divergência entre as disciplinas, cada qual cercando seu domínio em prol da autonomia e independência), obstáculos institucionais (relacionados às próprias instituições de ensino), obstáculos psicossociológicos (com a verificação de guetos do conhecimento, num incentivo à fragmentação como forma de poder, fortalecendo a tirania dos especialistas), obstáculos

\footnotetext{
${ }^{29}$ Ibid., p.78.

${ }^{30}$ Ibid., p.58.
} 
culturais (o fechamento dos cientistas de determinado país em suas capelas científicas, com o cultivo de uma linguagem hermética que os isola numa espécie de torre de marfim $)^{31}$.

A temática do aborto inegavelmente permite uma infinitude de considerações e análises. Assim, declaradamente, esta é uma pesquisa que se pauta pela viga mestra do diálogo, filho da interdisciplinaridade. Isto não significa, entretanto, que não haja delimitação do objeto de estudo; há. Mas delimitar não quer dizer, aqui, selecionar uma só disciplina para guiar a pesquisa.

N'outras palavras: o conceito de pessoa moral para análise do aborto provocado já é um recorte daquilo que se poderia tomar. Já é, em si, um quadro possível dentre vários. Mas dentro deste limite, não descartamos as contribuições de outras áreas do conhecimento.

E o que nos inspira é a possibilidade de uma nova abordagem sobre a complexa questão do aborto, que ultrapasse os paradigmas comumente utilizados nos debates. Objetiva-se, com esta conversação multifacetária, uma atitude interdisciplinar, que torne possível uma abordagem nova do velho. Há um movimento dialético nas atitudes interdisciplinares. "Partimos da afirmação de que o velho sempre pode tornar-se novo, e de que em todo novo existe algo de velho. Novo e velho - faces da mesma moeda - depende da óptica de quem a lê, da atitude disciplinar ou interdisciplinar de quem a examina",32.

A revisão dos estudos sobre o aborto provocado, além de ter como linha de condução a análise do conceito de pessoa moral, toma a linguagem visual para aprofundamento e expansão crítica do objeto de estudo, de forma a ampliar os horizontes sobre o tema.

O cinema, como se esclarecerá adiante, agrega ao debate um elemento afetivo que não é um antônimo do conhecimento científico. Ao contrário, possibilita uma forma de aproximação com o drama humano subjacente ao aborto.

Mas quem se lança em projetos com esse matiz deve situar o surgimento dessa forma de abordagem. Nesse capítulo introdutório, faz-se necessário estabelecer algumas das premissas da proposta interdisciplinar, o que inclui a menção a alguns dos primeiros estudos sobre o assunto e a própria terminologia que, numa primeira vista, aparenta ser de

\footnotetext{
${ }^{31}$ JAPIASSU, Hilton. Interdisciplinaridade e patologia do saber. Rio de Janeiro: Imago, 1976, pp. 94-100. "A este respeito, o interdisciplinar é um motor de transformação, talvez o único capaz de restituir vida a uma instituição praticamente esclerosada".

${ }^{32}$ FAZENDA, Ivani C. Arantes. Interdisciplinaridade: história, teoria e pesquisa. Campinas: Papirus, 2010 , p. 82 .
} 
difícil compreensão - o que permitirá que sejam desenhados os contornos dessa porta por onde entramos, e que inegavelmente é uma das diretrizes epistemológicas desse trabalho.

Os delineamentos do que se entende por saber interdisciplinar têm também a vantagem de afastar confusões reinantes entre aqueles que, sedizentes adeptos dessa maneira de enxergar as formas de conhecimento, nada mais fazem do que etiquetar-se em modismo incoerente. Daí a necessidade de proceder-se à precisa delimitação metodológica, o que enseja a especificação vocabular do que se entende por interdisciplinaridade, com a separação das ideias atinentes a outras palavras que costumam ser ligadas ao trabalho entre diversas disciplinas.

\subsection{Precisão terminológica: o estudo interdisciplinar}

$\mathrm{O}$ intuito de uma abordagem interdisciplinar tem por pressuposição lógica o esclarecimento acerca do que se compreende pelo próprio termo empregado. Nisso se situa um rigor necessário dos contornos da terminologia, o que milita em favor do entendimento das ideias defendidas.

Preliminarmente, é preciso repetir que a expressão interdisciplinar é neologismo que acabou por se converter em certo modismo, sem que se busque saber a real significação do termo. Em vez disso, dá-se esse nome à caracterização de estudos que, sob uma análise crítica, não são o que pretendem ser.

Daí a importância de explicitar o que este enfoque epistemológico não é. Desta feita, podemos dizer que não se trata de uma moda, mas uma verdadeira etapa de desenvolvimento do conhecimento. Não é uma panaceia, nem uma simples instauração de novos procedimentos educativos, pois reivindica uma categoria científica ${ }^{33}$.

Ademais, há uma miríade de expressões que, metodologicamente, não se confundem com o termo interdisciplinar, mas que podem ser utilizadas, erroneamente, como referentes a esse enfoque de estudo.

Em primeiro lugar, é necessário destacar que, por disciplina, aqui estamos nos referindo à ciência, e para esse trabalho disciplinaridade.

significa a exploração científica especializada de determinado domínio homogêneo de estudo, isto é, o conjunto sistemático e organizado de conhecimentos que apresentam características próprias nos planos do ensino, da

\footnotetext{
${ }^{33}$ JAPIASSU, Hilton. Interdisciplinaridade e patologia do saber. Rio de Janeiro: Imago, 1976, p. 51.
} 
formação, dos métodos e das matérias; esta exploração consiste em fazer surgir novos conhecimentos que se substituem aos antigos. ${ }^{34}$

Fala-se, ainda - e aqui vem a calhar a discriminação conceitual - em multidisciplinaridade, pluridisciplinaridade e transdisciplinaridade. Todas pressupõem a existência de mais de uma disciplina em contato, diferenciando-se, entretanto, no que pertine à integração entre as ciências. A interdisciplinaridade, nesta ordem, estaria entre a pluridisciplaridade e a transdisciplinaridade. Mas, afinal, o que quer dizer integração entre as disciplinas?

A multidisciplinaridade nada mais é do que um amontoado de disciplinas que não logram êxito em qualquer comunicação mínima entre si. Seria uma configuração de conhecimentos, cada qual mantendo os limites destacados do outro, ou seja, sem qualquer espécie de cooperação. A pluridisciplinaridade funciona também como um agrupamento de disciplinas com alguma cooperação entre si, mas não ostenta ordenação. Pode-se dizer sobre uma justaposição com algumas trocas, o que não deixa de ser, tal como a multidiscilplinaridade, um conglomerado disciplinar num mesmo nível. A interdisciplinaridade avança o passo ao incluir um outro nível de disciplinas, e introduz a noção de finalidade. O interdisciplinar

pode ser caracterizado como o nível em que a colaboração entre as disciplinas ou entre os setores heterogêneos de uma mesma ciência conduz interações propriamente ditas, isto é, a uma certa reciprocidade nos intercâmbios, de tal forma que, no final do processo interativo, cada disciplina saia enriquecida ${ }^{35}$.

A noção de diálogo e comunicação é a tônica que caracteriza o que se denomina interdisciplinar. Há que se verificar, portanto, não apenas a aglomeração ou justaposição de saberes, ainda que com coordenação mínima. É necessário um efetivo intercâmbio, em que

\footnotetext{
${ }^{34}$ Ibid., p. 72. Para caracterização de uma disciplina científica, o autor destaca algumas características ou elementos que a qualificam como tal: a) domínio material (objeto da qual se ocupa); b) domínio de estudo (ângulo específico do domínio material); c) nível de integração teórica; d) métodos próprios; e) instrumentos de análise que se relacionam à estratégia lógica e construção de modelos; f) reflexo das contingências históricas. Como esclarece Japiassu, “disciplinaridade é essa progressiva exploração científica especializada numa certa área ou domínio homogêneo de estudo. Uma disciplina deverá, antes de tudo, estabelecer e definir suas fronteiras constituintes. Fronteiras estas que irão determinar seus objetos materiais e formais, seus métodos e sistemas, seus conceitos e teorias. Ora, falar da interdisciplinaridade é falar de interação de disciplinas. E disciplina, tal como entendemos, é usada como sinônimo de ciência, muito embora o termo 'disciplina' seja mais empregado para designar o 'ensino de uma ciência', ao passo que o termo 'ciência' designa mais uma atividade de pesquisa" (pp.60-61).

${ }^{35}$ Ibid., pp. 71-77.
} 
cada uma das ciências possa contribuir e receba em troca algo que the seja acrescido em termos cognitivos.

O transdisciplinar, termo cunhado por Piaget, por sua vez, é aproximação ideal entre as disciplinas, a que ainda não chegamos.

Há na transdisciplinaridade múltiplos níveis de disciplinas, com uma base axiomática geral. Seria "uma etapa superior, que não se contentaria em atingir interações ou reciprocidade entre pesquisas especializadas, mas que situaria essas ligações no interior de um sistema total, sem fronteiras estabelecidas entre as disciplinas" ${ }^{36}$.

Aprofundando a temática da interdisciplinaridade, é possível realizar, inclusive, uma sistematização em tipos variados, o que permite concluir acerca do interesse sobre o estudo desse tema.

Fala-se, portanto, em: a) interdisciplinaridade heterogênea, que se apresenta sob a forma de um enciclopedismo ingênuo e superficial; b) pseudointerdisciplinaridade, que se vale do emprego de instrumentos conceituais comuns, "neutros"; c) interdisciplinaridade auxiliar, em que uma disciplina empresta seus métodos de análise a outra; d) interdisciplinaridade compósita, em que se nota uma aglomeração de disciplinas, cada qual guardando autonomia entre si, utilizando seus próprios métodos e, por fim, e) interdisciplinaridade unificadora, em que há, de fato, uma coerência estreita dos domínios das disciplinas ${ }^{37}$.

É bem verdade que o "mal uso de uma ideia", ou seja, sua compreensão equivocada e assim transmitida e retransmitida, gera a crença de que a ideia deformada é aquilo que originalmente se pretendia propagar. Talvez alguma resistência quanto às aproximações interdisciplinares no Brasil deva-se justamente a isso, à forma como foi encampada no sistema educacional, nas escolas.

Mister procedermos a um breve histórico que foi determinante na emergência desse enfoque especifico, interdisciplinar.

\footnotetext{
${ }^{36}$ Ibid., p. 75. Nas palavras de Piaget, relembradas por Japiassu. Conforme as relações que possam existir entre as disciplinas, podemos falar em contiguidade, fronteira, amplos recobrimentos, dependência, interdependência, transespecificidade e transcausalidade. Cada uma dessas relações está ordenada num crescente de conexões (p. 89).

${ }^{37}$ Ibid., pp. 79-80.
} 


\subsection{A crise das ciências? ${ }^{38}$}

O estudo histórico da concepção de interdisciplinaridade pode ser realizado de duas maneiras. Sob um primeiro enfoque, implica discorrer sobre o modo como se deu a mudança de uma compreensão ampla do mundo para a segmentação crescente, desde as primeiras civilizações; numa segunda abordagem, tem-se ao centro os estudos da interdisciplinaridade no Brasil.

Sob o ponto de vista do primeiro enfoque, podemos observar três concepções básicas: clássica, cristã e moderna ${ }^{39}$.

No início, podemos dizer que predominava o entendimento do mundo considerado de maneira global, como se o conhecimento das coisas fizesse parte de uma apreensão unitária do saber, sem compartimentações, o que predominou até a Idade Média. Deveras,

a idéia ${ }^{40}$ de um tempo do saber unitário sempre existiu na história do pensamento. $\mathrm{O}$ mito para o homem pré-histórico, a idéia de cosmos no mundo grego e a aceitação de um Deus criador e protetor do cosmos na Idade Média sempre sustentaram a unidade do saber e garantiram a integridade do horizonte epistemológico ${ }^{41}$.

$\mathrm{Na}$ Grécia, destaca-se o programa de ensino que se chamava enkúklios paidéia, que não era um mero enciclopedismo, uma justaposição de disciplinas ou conhecimentos, mas

\footnotetext{
38 JAPIASSU, Hilton. Desistir do pensar? Nem pensar!: criando o sentido da vida num mundo funcional e instrumental. São Paulo: Letras\&Letras, 2001, p. 47. Neste livro, o autor explora de modo detalhado, por meio da compilação e reescritura de palestras proferidas, a "crise da razão", ou a razão na história das ciências. Expressamente conclui que "não é a ciência que está em crise, mas a visão da ciência e do conhecimento proposta pelo cientificismo, notadamente sob sua forma reducionista: pretensão de 'reduzir' todo o fenômeno a um único tipo de explicação, principalmente de tipo físico e materialista". Também repetindo a lição sobre a "crise da razão", e retomando ideias já abordadas em outros livros, o autor dedica o capítulo segundo de outra obra sua. Cf, nesse sentido, JAPIASSU, Hilton. O sonho transdisciplinar e as razões da Filosofia. Rio de Janeiro: Imago, 2006, pp. 85-155.

${ }^{39}$ JAPIASSU, Hilton. Interdisciplinaridade e patologia do saber. Rio de Janeiro: Imago, 1976, p. 170.

${ }^{40}$ Embora este trabalho esteja escrito conforme o novo acordo ortográfico, mantivemos as citações de acordo com o original, não padronizando as palavras à nova ortografia.

${ }^{41}$ Ibid., pp. 45-46. Destaca o autor que "há, porém, uma diferença essencial entre a concepção grega e a concepção medieval do homem. $\mathrm{O}$ homem antigo professava uma fé religiosa e reconhecia uma ordem divina que não estava fora, mas dentro do cosmos. Toda a realidade - a natureza, os homens e os próprios deuses submetia-se à lei imanente ao cosmos. As potências supremas não estavam 'diante' ou 'além dos cosmos, mas em seu interior. $\mathrm{O}$ homem não conhecia nenhum ponto exterior ao mundo. Todos os seus movimentos desenvolviam-se no interior do mundo. Sua imagem do mundo era o resultado de uma autolimitação, afastando o infinito caótico, renunciando ao desmedido de harmonia relativamente ao qual o ser era sentido e pensado como cosmos, isto é, como beleza ordenada. Numa palavra, o homem antigo ignorava a transcendência divina. Por isso, era marcadamente diferente do homem medieval que acreditava na revelação bíblica e afirmava a presença de Deus no mundo e, mesmo, de modo especial, no coração do homem".
} 
sim uma concatenação harmônica, com vista à formação da personalidade integral, numa espécie de cultivo de cultura geral. Nota-se na Idade Média, por outro lado, a figura do sábio, e as outras ciências não deixavam de estar ligadas, em certo sentido, à filosofia. O saber era tomado em sua totalidade, num esquema global, amplo, em que o todo é o que tem relevância - o que se verifica nas Sumas ${ }^{42}$.

Estas são as concepções clássica e cristã, verificáveis no mundo antigo e no mundo medieval, respectivamente.

Esse quadro de unidade do saber, de apreensão do mundo de modo mais global e amplo, rui com o passar do tempo, tendo seu golpe certeiro com o advento da Era Moderna.

A efervescência de acontecimentos dá inicio a certa desintegração do conhecimento.

\begin{abstract}
O tempo do saber unitário sofre, com o advento da Idade Moderna, um processo de desintegração crescente. O grande corte ou mutação situa-se a partir da Renascença, da Reforma e das Grandes Descobertas. Esses 'movimentos' invadem todos os setores da cultura e desmorona o horizonte familiar e protetor do cosmos que delimitava o espaço mental há milênios. O homem passa a tomar consciência de si num universo indefinidamente ampliado ${ }^{43}$.
\end{abstract}

Há uma proliferação de novos saberes, e uma dissociação cada vez maior entre cada disciplina, uma verdadeira desintegração do conhecimento, uma proliferação anárquica de domínios cada vez mais restritos do saber ${ }^{44}$, uma ruptura da síntese $e^{45}$.

E este é o quadro que seria desafiado pela concepção epistemológica da interdisciplinaridade.

Passemos agora a um breve esboço acerca dos estudos sobre essa forma metodológica no Brasil.

Porém, antes de revelarmos os primeiros passos da interdisciplinaridade por aqui, como objeto de estudo destacado, faz-se oportuno salientar que o movimento da interdisciplinaridade está intimamente ligado aos estudos pedagógicos, aos debates sobre o

\footnotetext{
${ }^{42}$ Ibid., pp. 46-47.

${ }^{43}$ Ibid., p.47.

${ }^{44}$ Ibid., p. 49

${ }^{45}$ Ibid., p. 172. "A partir do Renascimento, começa a se decompor a harmoniosa unidade da espiritualidade medieval. Forte é a pressão exercida pelas disciplinas emergentes. Com a dignificação da individualidade do homem, cada vez mais ele passa a ser o centro dos valores e do conhecimento. O novo mundo se dá uma leitura antropológica e, ao mesmo tempo, antropocêntrica".
} 
ensino e o aprendizado que em certo momento da história passaram a ser questionados, pugnando os estudiosos por uma reformulação da situação-escola, da academia, das relações entre alunos e professores.

As pesquisas sobre o interdisciplinar como possibilidade de estudo que tem ao centro uma forma específica de diálogo são deveras recentes, datando de pouco mais de meio século. "O movimento da interdisciplinaridade surge na Europa, principalmente na França e na Itália, em meados da década de 1960 (...) época em que se insurgem os movimentos estudantis, reivindicando um novo estatuto de universidade e de escola" 46 .

Além disso, tal pesquisa faz parte de uma reação que exsurge num contexto em que se proclama a crise das ciências. Esclarece Ivani C. A. Fazenda que

\footnotetext{
Fala-se em crise de teorias, de modelos, de paradigmas (...) Tudo nos leva a crer que o exercício da interdisciplinaridade facilitaria o enfrentamento dessa crise do conhecimento e das ciências, porém é necessário que se compreenda a dinâmica vivida por essa crise, que se perceba a importância e os impasses a serem superados num projeto que a contemple ${ }^{47}$.
}

Pode-se dizer que falar sobre uma crise do saber, nos moldes como a ciência foi estruturada e alçada a uma importância tal, significa repensar a relação entre os homens e o próprio conhecimento e refletir sobre o entrosamento entre o homem e o mundo e o papel do subjetivo nisso tudo - o que tem repercussão indiscutível nas próprias teorias cognitivas que se elaboram hoje. Impende proceder a uma reflexão não demorada sobre esse aspecto, que auxiliará na compreensão do rumo interdisciplinar que aqui tomamos.

No prefácio da Árvore do conhecimento, de Maturana e Varela - autores com inegável contribuição na seara da teoria do conhecimento - Humberto Mariotti refere-se criticamente ao representacionismo, que seria uma maneira consolidada de pensar o mundo de modo que o que apreendemos, vemos e descrevemos já está lá, como um dado objetivo, parte da natureza à disposição do homem. Há nisto, destaca o médico, um abandono da subjetividade, que não pode corromper a ciência, tomada num pedestal de objetividade, sob pena de comprometimento da exatidão científica.

Assim, essa apreensão do mundo como algo dado reflete na extração, pelo homem, dos produtos da natureza, como se o construto natural estivesse à nossa disposição. E foi

\footnotetext{
${ }^{46}$ FAZENDA, Ivani C. Arantes. Interdisciplinaridade: história, teoria e pesquisa. Campinas: Papirus, 2010, p. 18.

${ }^{47}$ Ibid., p.14.
} 
assim que, em muitas empreitadas colonizatórias, os nativos foram escravizados, também por serem considerados um produto da natureza para exploração. Ali, entremeio a selva e a floresta, eram percebidos como matéria bruta a ser utilizada conforme os desígnios daqueles que chegavam nas terras novas - pensamento que ainda está longe de ser completamente superado, haja vista as próprias discussões éticas existentes acerca das relações entre o homem e o meio ambiente natural.

A premissa da qual partem Maturana e Varela é desconstrutiva desse aspecto: é preciso não se esquecer de que nós também construímos o mundo, e os aspectos subjetivos influenciam bastante aquilo que entendemos e que tomamos apressadamente como algo acabado, pronto para ser tomado. Ou seja,

\begin{abstract}
nossa trajetória de vida nos faz construir nosso conhecimento do mundo - mas este também constrói seu próprio conhecimento a nosso respeito. Mesmo que de imediato não o percebamos, somos sempre influenciados pelo que vemos e sentimos. Quando damos um passeio pela praia, por exemplo, ao fim do trajeto estaremos diferentes do que estávamos antes. Por sua vez, a praia também nos percebe. Estará diferente depois de nossa passagem: terá registrado nossas pegadas na areia - ou terá de lidar também com o lixo com o qual porventura tenhamos poluído ${ }^{48}$.
\end{abstract}

N'outras palavras, o pensamento dos autores serve para contrabalançar alguns dos pilares rigidamente construídos em torno da ciência e da razão, especialmente a sua objetividade pura, que desconsidera o caráter interativo que existe no mundo ao redor dos homens, e entre o próprio homem e o mundo. Ademais, seria de pouca cautela falar-se em uma neutralidade científica, isenta de qualquer mínima influência da subjetividade. A própria escolha de um método, e não de outro, já nos permite identificar uma boa dose de influência valorativa.

Nesse sentido, podemos dizer que a interdisciplinaridade admite uma ponderação entre os aspectos subjetivos e objetivos, sendo

considerada como a mais recente tendência da teoria do conhecimento, decorrência obrigatória da modernidade, possibilitando que, na produção do saber, não se incida nem no radical cientificismo formalista (objetivismo), nem no humanismo exagerado (subjetivismo). Tal saber caracteriza-se por ser obtido

\footnotetext{
${ }^{48}$ MATURANA, Humberto R.; VARELA, Francisco R. A árvore do conhecimento: as bases biológicas da compreensão humana. São Paulo: Palas Athena, 2001, pp. 8-10.
} 
a partir da predisposição para um encontro entre diferentes pontos de vista (diferentes consciências), o que pode levar, criativamente, à transformação da realidade ${ }^{49}$

Sob outra linha de análise, Hilton Japiassu, em um de seus muitos estudos acerca do assunto, refere-se à crise das ciências, do saber objetivo, e da razão, relacionando os movimentos de interligação com o irracional. Fala de uma espécie de racionalização do irracional, que ocorre em alguns ramos da ciência, ou mesmo uma integração entre o racional e o irracional, como ocorreu em outras épocas, o que seria uma recuperação quase que nostálgica de outros tempos.

Escreve o autor que

muitos falam da crise atual do Pensamento, da Razão, da Ciência. Mas esta crise é providencial. No que diz respeito à ciência, permite-nos lutar para que libertemos de seu fascínio cientificista e resistamos às sirenes do irracional (ou às sereias irracionalistas). Esta resistência se dá, senão in totum, pelo menos em boa parte, no nível da reflexão filosófica. Porque é neste nível que as diferentes formas de pensamento se abrem umas às outras e instauram um diálogo tornando-as parceiras nesta incansável busca de uma unidade do pensamento (não de uma homogeneidade), mas de uma unidade de movimento. Neste caminhar, nenhuma ciência (nenhuma filosofia) pode lançar mão de seu prestígio para impor sua autoridade. $^{50}$

Aqui, a aliança que empreendemos entre as diversas áreas não é mística. Não se trata de qualquer aproximação para entendimento mais completo do objeto sob análise ${ }^{51}$

Definitivamente, não se trata desse tipo de tratamento global. Buscamos, isto sim, um esforço de comunicação entre as formas variadas de expressão do humano e da ciência, que amplie e renove o olhar sobre o aborto, (com)partilhando as contribuições de cada uma numa síntese nova - e possível.

${ }^{49}$ PRADO, Lídia Reis de Almeida. O juiz e a emoção: aspectos da lógica da decisão judicial. Campinas: Millennium, 2008, p. 9

${ }^{50}$ JAPIASSU, Hilton. A crise da razão e do saber objetivo: as ondas do irracional. São Paulo: Letras \& Letras, 1996, p.44.

${ }^{51}$ JAPIASSU, Hilton. As paixões da ciência: estudos de história das ciências. São Paulo: Letras \& Letras, 1991, pp.189-190. Escreve Japiassu que "a fragmentação crescente das ciências em disciplinas cada vez mais especializadas e compartimentadas, seguida de uma acelerada divisão do trabalho científico entre "teóricos" e "práticos", entre pesquisadores e técnicos, faz com que a maioria dos cientistas atuais perca uma visão global do mundo fundada em sua prática. Donde não ser estranho que, a fim de resgatar certa visão globalizante, mesmo que limitada e deformada como era, muitos cientistas se vêem tentados aos mais variados tipos de compromissos com pensamentos não ou extra-racionais". 
O conhecimento delimitado por uma ciência, considerado como próprio e específico, pode ser transposto e codificado sob a forma de linguagem, que não se isola completamente, tornando-se impenetrável àquilo que exprime outras ciências. Há um elo comum entre cada uma delas, o que torna viável o diálogo.

No Brasil, a inserção de uma metodologia interdisciplinar, após os primeiros estudos desenvolvidos na Europa, deu-se de forma distorcida, sob o amparo da entidade estatal. Destaca Ivani C. Arantes Fazenda que

\begin{abstract}
em nome da interdisciplinaridade, todo o projeto de uma educação para a cidadania foi alterado, os direitos do aluno/cidadão cassados, através da cassação aos ideais educacionais mais nobremente construídos. Em nome de uma integração, esvaziaram-se os cérebros das universidades, as bibliotecas, as pesquisas, enfim, toda a educação. Foi tempo de silêncio, iniciado no final dos anos 50, que percorreu toda a década de 1960 e a de 1970. Somente a partir de 1980 as vozes dos educadores voltaram a ser pronunciadas. A interdisciplinaridade encontrou na ideologia manipuladora do Estado seu promotor maior. Entorpecido pelo perfume desse modismo estrangeiro, o educador se omitiu e nessa omissão perdeu aspectos de sua identidade pessoal $^{52}$.
\end{abstract}

Anos de desenvolvimento de uma postura estatal assim deixaram marcas que seriam percebidas entre os profissionais da educação, e sentidas pelo alunado - dessas interferências estatais que, a pretexto de propiciar o melhor em termos pedagógicos, simplesmente distorcem os reais propósitos educacionais subjacentes à metodologia interdisciplinar pensada.

Contudo, apesar dessa perda de identidade das décadas de 1960 e 1970, a que alude Ivani C. Arantes Fazenda, "tal como Fênix, o educador dos anos 80 renasceu das cinzas, em busca de seu passado de glórias e de sua afirmação profissional"

A autora citada destaca, ainda, as ondas da interdisciplinaridade no Brasil, delineando como se deram as suas pesquisas sobre o assunto. Trata-se de esboçar as principais características verificadas em três décadas, dos anos 70 aos anos 90.

Na linha de desenvolvimento, pode-se dizer que, em 1970, ocorreu a construção epistemológica da interdisciplinaridade; em 1980, a explicitação das contradições

${ }^{52}$ FAZENDA, Ivani C. Arantes. Interdisciplinaridade: história, teoria e pesquisa. Campinas: Papirus, 2010, p. 30.

${ }^{53}$ Ibid., p. 30 
epistemológicas decorrentes dessa construção e em 1990, a tentativa de construir uma nova epistemologia $^{54}$.

Isto considerado, a questão que se põe é: o que possibilita a interdisciplinaridade em termos cognitivos, que a torna um modo de abordagem tão inovador para o cientista? Em outras palavras, por que, afinal, a interdisciplinaridade? O que a interdisciplinaridade propicia?

\subsection{Justificativas e métodos da interdisciplinaridade}

Verificado um breve histórico sobre a ideia de uma abordagem interdisciplinar, impende destacar como se avulta em importância tal modo de análise, que constitui uma das premissas metodológicas que aqui se adota: esse estudo apresenta uma proposta interdisciplinar franca, baseada na crença de ela ser mais pertinente àquilo que aqui se pretende estudar. É possível elencar algumas das motivações essenciais do emprego dessa forma de análise ${ }^{55}$.

Em primeiro lugar, o surgimento de problemas novos, que a própria investigação científica e as mudanças sociais trazem, clama formas diferentes e inovadoras de apreensão desses reais desafios, o que principia com uma tomada de consciência acerca da insuficiência de padrões cognitivos assentados.

Deveras,

a primeira e mais radical justificação de um projeto de pesquisa interdisciplinar que ultrapasse os quadros das diferentes disciplinas científicas, deve, pois, ser procurado na complexidade dos problemas aos quais somos hoje em dia confrontados, para chegar a um conhecimento do humano, se não em sua integridade, pelo menos numa perspectiva de convergência de nossos conhecimentos parcelares. Conscientemente ou não, os especialistas decompõem o homem em pedaços ${ }^{56}$.

\footnotetext{
${ }^{54}$ Ibid., p.17.

55 JAPIASSU, Hilton. Interdisciplinaridade e patologia do saber. Rio de Janeiro: Imago, 1976, pp.164166. O autor se refere a alguns dos objetivos propriamente epistemológicos das pesquisas interdisciplinares. Destacamos que elas: a) concorrem para que se intensifiquem as trocas de informações entre as disciplinas, favorecendo o trabalho comum e organizado; b) contribuem para a explosão dos isolacionismos epistemológicos dos saberes monodisciplinares; c) superam os obstáculos à comunicação entre os cientistas e ao trabalho em equipe; d) colocam em questão a inércia das instituições de ensino; e) aproximam e propiciam interação entre membros de uma comunidade científica; f) proporcionam aos pesquisadores um intercâmbio generalizado de críticas, possibilitando uma reorganização e integração orgânica do meio científico; g) propiciam o questionamento da acomodação dos pesquisadores.

${ }^{56}$ Ibid., p. 62
} 
A Bioética, sem qualquer dúvida, apresenta algumas das questões mais tormentosas do universo humano, e torna-se impossível sequer apreender o problema sem que se lance numa empreitada dialógica.

Em segundo lugar, o enfoque interdisciplinar possibilita uma expansão da possibilidade do próprio saber, ao estabelecer os elos perdidos com a especialização e separação presente em várias áreas do conhecimento. É, além de tudo, uma expansão criativa, que desvenda horizontes novos, dissipando o véu de névoa que impede que cada um se veja.

Por fim, pode-se dizer que

\begin{abstract}
a interdisciplinaridade enfatiza o homem enquanto ser social (que vive numa sociedade tecnologicamente desenvolvida), dotado de afetividade (que se relaciona com sua realidade interna) e com outros seres do meio em que vive. Possibilita, assim, a superação de um tipo de saber feito de especializações formais, o saber em migalhas, o saber sem sabor, que provoca a perda da visão da totalidade. Conforme a concepção sistêmica, até mesmo nas ciências da natureza (como nos mostram, por exemplo, as conquistas da Física moderna), inexiste distinção entre parte e todo, porque cada sistema é simultaneamente todo e parte, dependendo do ponto de referência ${ }^{57}$.
\end{abstract}

Dizemos que o homem é eminentemente comunicativo, e imerso na linguagem troca mensagens com o meio a sua volta, o que inclui, num sentido amplo, os diálogos que tece, a sua relação com a natureza - como ser pertencente ao ambiente que o circunda. A interação é inseparável da convivência, e tudo no mundo está em permanente troca.

Enfim, pontifica Ivani C. Arantes Fazenda que

a metodologia interdisciplinar parte de uma liberdade científica, alicerça-se no diálogo e na colaboração, funda-se no desejo de inovar, de criar, de ir além e exercitar-se na arte de pesquisar - não objetivando apenas uma valorização técnico-produtiva ou material, mas, sobretudo, possibilitando uma ascese humana, na qual se desenvolva a capacidade criativa de transformar a concreta

\footnotetext{
${ }^{57}$ PRADO, Lídia Reis de Almeida. O juiz e a emoção: aspectos da lógica da decisão judicial. Campinas:
} Millennium, 2008, p. 9. 
realidade mundana e histórica numa aquisição maior de educação em seu sentido lato, humanizante e liberador do próprio sentido de ser-no-mundo ${ }^{58}$.

A criatividade ínsita à interdisciplinaridade leva por vezes que o pesquisador intua relações possíveis entre os dados que possui acerca da matéria analisada. Há nisso um empenho de tentar o novo, de provar e degustar as mais variadas formas de combinação que o pensamento pode compor.

Por vezes, há uma versão de linguagens distintas, experimentação de velhas composições que, rearranjadas, tornam-se fonte nova. Esse entusiasmo que move o pesquisador nesse caminho é um reflexo da perene curiosidade, que motiva novas maneiras de encarar a vida,

porque o interdisciplinar exige uma situação de abertura e de curiosidade, um esforço crítico para descobrir as causas e os fenômenos, um gosto pela síntese, uma pedagogia fundada sobre o trabalho em equipe, um treinamento à maleabilidade dos espíritos ${ }^{59}$.

Para finalizar, é importante destacar que a interdisciplinaridade - que também denominamos de método - possibilita, na verdade, que pensemos em métodos. Conforme as formas de abordagem do trabalho interdisciplinar, poderemos falar em dois níveis de realização: a) nível prospectivo; b) nível retrospectivo.

No primeiro, também denominado de tarefa interdisciplinar,

há um apelo, diretamente, à realidade concreta dos empreendimentos humanos e da história. Neste caso, toma efetivamente corpo entre os cientistas que se interagem, na medida em que orientam suas pesquisas para um objetivo de ordem prática: a aplicação tem em vista a procura de um objeto comum aos vários conhecimentos a se traduzirem em prática ${ }^{60}$.

${ }^{58}$ FAZENDA, Ivani C. Arantes. Interdisciplinaridade: história, teoria e pesquisa. Campinas: Papirus, 2010, pp. 69-70.

${ }_{59}^{5}$ JAPIASSU, Hilton. Interdisciplinaridade e patologia do saber. Rio de Janeiro: Imago, 1976, p. 140.

${ }^{60}$ Ibid., pp. 122-123. 
O segundo método, também chamado de reflexão interdisciplinar, "está empenhado em isolar um momento da experiência do saber a fim de determinar-lhe a estrutura fundamental e de referir esta estrutura à unidade do ato fundador de sentido" ${ }^{61}$.

Os dois métodos são complementares, sendo impossível esboçar o isolamento de um ou de outro. De fato, alerta Japiassu que

só há reflexão se houver um conteúdo servindo-lhe de suporte. E é para que a reflexão possa dar-se um conteúdo, que se torna imprescindível a pluralidade de enfoques. Em outras palavras, uma reflexão desprovida de conteúdo, melhor ainda, que não tenha por suporte uma tarefa, seria uma atividade intelectual pura e simplesmente formal, sem nenhum interesse cognitivo. Por outro lado, sem o nível prospectivo da tarefa interdisciplinar, o nível retrospectivo da reflexão estaria fadado à esterilidade e, muito em breve, ao impasse; mas sem este segundo nível, o primeiro estaria fatalmente condenado ao pragmatismo e, muito provavelmente, à arbitrariedade ${ }^{62}$.

É pertinente delinear, brevemente, as principais formas de "composição" que permeiam essa pesquisa.

\subsection{Principais diálogos estabelecidos nessa pesquisa}

Declarou-se que inúmeras são as possibilidades de comunicação entre as ciências, nas mais variadas áreas do conhecimento.

Contudo, pelos propósitos desse estudo - uma dissertação de mestrado - seria inviável, ainda que com a delimitação de um tema, realizar uma análise com o auxílio e confluência de um número ilimitado de ciências-base. Deveras, semelhante tentativa destoaria do humanamente possível, além de arriscada e extremamente superficial, a ponto de sequer suscitar qualquer discussão crítica. Talvez servisse como mero folhetim enciclopédico, desprovido de qualquer interesse acadêmico.

A Bioética, conforme aprofundaremos, já é um discurso eminentemente interdisciplinar, e acolhe conteúdos de inúmeras áreas da ciência, como a Biologia, a Medicina, a Psicologia. O Direito também está intimamente relacionado a todas essas discussões, pois lida com problemas humanos. E, conforme pontifica Carlos María

\footnotetext{
${ }^{61}$ Ibid., p. 123.

${ }^{62}$ Ibid., p. 124.
} 
Cárcova, os estudos jurídicos foram enriquecidos nas últimas décadas pela contribuição de outras disciplinas, superando certo isolamento tradicional ${ }^{63}$.

Por fim, exploramos aqui uma forma de conversação entre o Direito e a Bioética com o cinema, na forma de linguagem visual que comunica e nos impele a pensar sobre as inúmeras questões que propõe. Como pondera Edgar Morin, "literatura, poesia e cinema devem ser considerados não apenas, nem principalmente, objetos de análises gramaticais, sintáticas ou semióticas, mas também escolas de vida, em seus múltiplos sentidos",64.

Em todas as searas que compõem as reflexões desse estudo, o tema do aborto apresenta-se como recorrente, como uma questão a ser pensada. Aqui, propomos repensar a abordagem tradicionalmente feita, e isso se dá por meio de uma confluência dessas disciplinas, que são harmonizadas de maneira possível.

Pontua Hilton Japiassu que é impossível uma abordagem interdisciplinar que seja realizada por um estudioso. No seu entender, "nenhuma pesquisa realmente interdisciplinar pode ser encetada por um único indivíduo, pois o mínimo que se pode dizer é que ela correria o risco de padecer de um autodidatismo injustificável" ${ }^{65}$.

Contudo, entendemos que é possível, sim, desenvolver um estudo interdisciplinar a partir da apreensão de teorias e conhecimentos de múltiplas áreas do saber, inclusive encampando manifestações artísticas. De fato, em nossa visão, o interdisciplinar supõe não a mera troca de conhecimentos, mas a internalização autêntica de conhecimentos e vivências (como no caso das manifestações artísticas). Especialmente nesse último caso é impossível que alguém se subsuma à experiência de experimentar a Arte, de modo a simplesmente assimilar aquilo que o "especialista" ensina. Há um sentido existencial, que não se apreende pelo outro, mas, ao contrário, parte de cada um.

Aliás, Japiassu destaca, em passagem posterior da mesma obra, que

o verdadeiro espírito interdisciplinar consiste nessa atitude de vigilância epistemológica capaz de levar cada especialista a abrir-se às outras

${ }^{63}$ CÁRCOVA, Carlo María. Derecho y Narración. In: TRINDADE, André Karam; GUBERT, Roberta Magalhães; COPETTI NETO, Alfredo (org). Direito \& Literatura: ensaios críticos. Porto Alegre: Livraria do Advogado, 2008, p.11.

${ }^{64}$ MORIN, Edgar. A cabeça bem-feita: repensar a reforma, reformar o pensamento. Rio de Janeiro: Bertrand Brasil, 2000, pp. 48-51. Fala o autor em escolas da língua, da qualidade de poética da vida, da descoberta de si, da complexidade humana, da compreensão humana. "Literatura, poesia, psicologia, filosofia deveriam convergir para tornar-se escolas da compreensão. A ética da compreensão humana constitui, sem dúvida, uma exigência chave de nossos tempos de incompreensão generalizada: vivemos em um mundo de incompreensão entre estranhos, mas também entre membros de uma mesma sociedade, de uma mesmas família, entre parceiros de um casal, entre filhos e pais".

${ }^{65}$ JAPIASSU, Hilton. Interdisciplinaridade e patologia do saber. Rio de Janeiro: Imago, 1976, p. 126. 
especialidades diferentes da sua, a estar atento a tudo o que nas outras disciplinas possa trazer um enriquecimento ao seu domínio de investigação e a tudo o que, em sua especialidade, poderá desembocar em novos problemas e, por conseguinte, em outras disciplinas. $\mathrm{O}$ espírito interdisciplinar não exige que sejamos competentes em vários campos do saber, mas que nos interessemos, de fato, pelo que fazem nossos vizinhos em outras disciplinas ${ }^{66}$.

E é este o espírito de que estamos imbuídos: abertura ao diálogo e às contribuições que podem trazer os demais ramos do conhecimento.

Neste caminho, a Filosofia é instância crítica não apenas aos projetos com caráter pluridisciplinar, mas interdisciplinar, revelando-se como a única disciplina em condições de fazer a unidade do objeto das ciências humanas ${ }^{67}$.

Para finalizar, importa sublinhar que não temos a pretensão de construir uma forma interdisciplinar de estudo que se apegue a um ideal de generalidade e universalidade, extraindo das disciplinas uma espécie de essência capaz de aproximação dos saberes.

Acreditamos que são possíveis construir pontes de diálogo e superar a fragmentação a que foi alçado o conhecimento a partir da Era Moderna, mas não cremos palpável um ideal de saber unitário, que não deixará de ser enciclopédico e generalista ${ }^{68}$.

Mister ressaltar, por fim, que este capítulo introdutório, assim como o capítulo que segue, estabelece alguns dos preceitos e postulados básicos que inspiram a pesquisa empreendida. São capítulos que assentam, enfim, o enfoque metodológico essencial.

Passemos ao estudo das premissas fundamentais que sustentam essa pesquisa, considerando com maior profundidade a forma como entendemos possível a conciliação dessas disciplinas. No capítulo que segue, algumas referências à interdisciplinaridade serão aprofundadas, especialmente no que concerne às relações entre Bioética, Cinema e Direito, ao modo como se torna possível o diálogo entre essas disciplinas e formas de manifestação artística.

\footnotetext{
${ }^{66}$ Ibid., p. 138.

${ }^{67}$ Ibid., p. 145.

${ }^{68}$ Ibid., p. 186. Para o autor, "se o ideal de unificação das ciências impõe-se cada vez mais na prática científica, não é menos verdadeiro que se revela um projeto de realização extremamente difícil no plano teórico, ainda que tenha ocupado um lugar importante e desempenhe um papel relevante no empirismo lógico, onde certamente se reveste de um colorido mais ou menos acentuado".
} 


\section{CAPÍTULO 2. O ABORTO EM CENA}

\subsection{Apresentação do problema e considerações metodológicas}

Há algumas décadas, despontou entre os ramos do saber um diálogo fecundo entre as ciências biológicas e as ciências humanas: a Bioética erigiu como um conhecimento dialético, um ramo específico da ética que se volta para questões humanas que têm no centro a própria vida.

O desenvolvimento da Medicina, quase exponencial nos últimos anos, agregou à Bioética novas questões, novos paradoxos de difícil equacionamento: clonagem, célulastronco, engenharia genética, seleção artificial de embriões com determinação de caracteres não essenciais, possibilidade de detecção de anomalias fetais, aumento da sobrevida no caso de doenças crônicas, prolongamento artificial da vida, alteração do fenótipo. Assim, tantos novos temas se somaram a outros questionamentos presentes na sociedade, alguns de longa data, como a eutanásia, pesquisa em animais e seres humanos, aborto.

Os fenômenos tornaram-se mais complexos, e os instrumentos para explicá-los e compreendê-los, alerta Carlos María Cárcova, não podem deixar de acompanhar essa complexidade ${ }^{69}$.

A Bioética é dinâmica, e reflete não só os avanços científicos, mas também a forma como a humanidade é influenciada pelos dilemas que se atualizam a cada dia, impulsionados pelas necessidades de uma decisão, que muitas vezes dizem respeito a extremos da vida e da morte. Deveras, leciona Marco Segre, a "Bioética é parte da ética, ramo da filosofia, que enfoca as questões referentes à vida humana (e, portanto, a saúde). A Bioética, tendo a vida como objeto de estudo, trata também da morte (inerente à ${\text { vida })^{70} \text {, }}^{2}$

Para melhor compreensão deste estudo, consideramos importante traçar os contornos do que se entende por dilema.

O dilema, na lógica, é compreendido como um silogismo composto, ou seja, é formado por vários silogismos simples. Na lição de Alaôr Caffé Alves,

${ }^{69}$ CÁRCOVA, Carlo María. Derecho y Narración. In: TRINDADE, André Karam; GUBERT, Roberta Magalhães; COPETTI NETO, Alfredo (org). Direito \& Literatura: ensaios críticos. Porto Alegre: Livraria do Advogado, 2008, p. 17.

${ }^{70}$ SEGRE, Marco. Definição de Bioética e sua relação com a Ética, Deontologia e Diceologia. In: COHEN, Cláudio (org). Bioética. São Paulo: Edusp, 1999, p.23. 
é o duplo silogismo com uma só conclusão. O dilema é um silogismo em que a premissa maior é uma proposição disjuntiva, constituída de tal forma que cada uma das partes conduz, sempre, à mesma conclusão. A premissa maior do dilema é uma proposição disjuntiva; a menor é uma condicional dupla. Se se toma um membro da disjuntiva, tira-se uma conclusão; se se toma o outro membro, segue-se a mesma conclusão" (...) Assim, mediante o dilema coloca-se o adversário entre duas alternativas das quais não pode escapar. $^{71}$

Este é um sentido estritamente lógico e formal do termo.

Deveras, salienta Irving M. Copi que, do ponto de vista lógico, o dilema não apresenta muita importância quando se compara à sua utilização como um poderoso instrumento de persuasão. Nas palavras do autor, em uma discussão, o dilema é uma arma devastadora. E, costumeiramente, diz-se que alguém está num dilema quando está entre duas possibilidades de escolha que acarretam, ambas, uma consequência má. Esta situação pode conduzir a uma situação que beira ao aniquilamento do sujeito, posto entre escolhas que não conduzem a bons resultados ${ }^{72}$.

Para atacar um dilema, ensina Copi, pode-se lançar mão de um contradilema, desconstruindo as premissas do dilema. Porém, com isso, ensina o autor, constrói-se um outro dilema com conclusão oposta à do dilema original ${ }^{73}$.

O presente trabalho utilizará o termo dilema no sentido de uma situação em que o sujeito se encontra e cujas opções de decisão o colocam numa "encruzilhada".

Mas a postura que aqui se adota é crítica, no sentido de evidenciar que não se trata, necessariamente, de se chegar às tais conclusões, negativas e más. E não uma ou outra, unicamente.

Feito este esclarecimento terminológico, é preciso destacar que o homem é, antes de tudo, um ser biológico. Mas não é apenas um ser biológico: é um animal cultural, que pensa, é autoconsciente e consegue transformar o mundo e a si mesmo, construindo conhecimento de modo cumulativo, ensejando considerações prospectivas sobre o próprio futuro, mesmo que tenha que se voltar para o passado.

\footnotetext{
${ }^{71}$ ALVES, Alaôr Caffé. Lógica: pensamento formal e argumentação. São Paulo: Quartier Latin, 2005, p. 284.

${ }^{72}$ COPI, Irving M. Introducción a la lógica. Buenos Aires: Editorial Universitária de Buenos Aires, 1962, p. 211-212.

${ }^{73}$ Ibid., pp. 213-215.
} 
Nesse sentido, salienta Tércio Sampaio Ferraz Jr. que o homem é percebido como um ser ambíguo, que ao mesmo tempo cria e transforma as estruturas do mundo, e delas faz parte como elemento de uma estrutura planificada. "O homem é autor e ator, sujeito e objeto da ação" ${ }^{74}$; constrói o mundo ao passo que se constrói.

Além disso, a diversidade moral possibilita que falemos em "bioéticas"; "existem muitas e profundas interpretações morais diferentes: a bioética está no plural”75. O pluralismo axiológico talvez seja uma marca do que se convencionou chamar de pósmodernidade, e dedicaremos um capítulo específico para tratar das relações existentes entre relativismo moral e aborto.

Diante desse quadro, o Direito, que não se modifica no mesmo ritmo dos avanços experimentados pela área médica, foi sacudido pela necessidade de decisão das novas questões que chegavam ao Poder Judiciário, estimulando, com isso, a formulação de inúmeros projetos, inclusive com a aprovação de algumas leis, constituindo-se de forma incipiente um Biodireito, como um conjunto de normas postas para decidir alguns dos novos conflitos.

É o caso de Lei de Biossegurança, que veio a lume em 2005, e que tanta polêmica causou ao permitir, em determinadas circunstâncias, a pesquisa com células-tronco embrionárias. No âmbito internacional, inúmeras leis também foram promulgadas e, em 2005, surgiu a Declaração Universal sobre Bioética e Direitos Humanos, expondo a importância de reflexão sobre as novas questões éticas.

O aborto, ainda que possa ser considerado uma das "velhas questões", continua a clamar por novas abordagens que não se resumam a polêmicas maniqueístas que insistem em dominar os debates, aniquilando-se umas às outras, como se estivessem opostas num cabo de guerra. Assim, por exemplo, há os debates alicerçados nas linhas argumentativas que se intitulam de pró-vida (pro-life) e pró-escolha (pro-choice), e que quase sempre se apresentam como antagônicos, com discurso veiculador da resposta correta. O primeiro, apegado à individualidade genética, destaca o valor sagrado e inviolável da vida, objetando, pois, a interrupção da gravidez. O segundo, por sua vez, sublinha a possibilidade de escolha, de se optar pela interrupção da gravidez, acima de qualquer valor sagrado. E, nesse embate, não parece haver consenso.

Na seara da interrupção da gravidez,

\footnotetext{
${ }^{74}$ FERRAZ JR., Tércio Sampaio. A ciência do Direito. São Paulo: Atlas, 2006, p. 40.

${ }^{75}$ ENGELHARDT Jr., H. Tristam. Fundamentos da Bioética. São Paulo: Loyola, 2004, p. 36.
} 
o Direito não pode mostrar-se indiferente, neutro. Tem de intervir, superando o conflito, arbitrando-o, dando-lhe solução: é sua missão essencial. Agirá, verificada a inevitabilidade do dano que acarrete uma ou outra preservação, seja da gestante, seja do filho, legitimando opção pelo mal menor ${ }^{76}$.

Mas essa intervenção não pode ser estritamente proibitiva, apegando-se aos dogmas que se sustentam numa e noutra corrente. E, vale destacar, a matriz ideológica acatada pelos diplomas legais existentes, que proíbem a interrupção da gravidez ou só a permitem em casos extremos (risco de morte para a gestante ou estupro), assenta-se na proteção da vida intrauterina, o que não deixa de ser uma tomada de posição, um afastamento da neutralidade. A intervenção jurídica, contudo, deve ser aquela que tome em consideração cada caso, sem predeterminar as soluções, o que aparenta ser mais razoável. Deveras, o aborto envolve uma multiplicidade de valores, não podendo um deles (a vida) sobrepujarse de antemão pela fossilização legislativa, em total desconsideração das peculiaridades existentes numa dada situação.

Por isso elegemos o tema do aborto como objeto de estudo. Salienta H. Tristam Engelhardt Jr. a diversidade moral existente hoje e escreve que

a estridência do debate sobre o aborto assinala a força desses desacordos. Alguns consideram o aborto um mal moral e profundo (...), enquanto outros o vêem, no máximo, como um mal físico. O debate em torno do aborto é apenas uma de muitas questões em que as controvérsias são, ao mesmo tempo, apaixonadas e refletem visões morais conflitantes e arraigadas ${ }^{77}$.

Nesse passo, destacamos que estudos concernentes à problemática do aborto podem ter diferentes pontos de partida, independentemente das suas conclusões, e assim também diferentes enfoques no seu desenvolvimento, cada qual com um escopo ou fim específico. Além disso, a forma de abordagem plural que o tema possibilita tem ensejado trabalhos diversificados nas mais diferentes áreas do conhecimento.

Além da multiplicidade de perspectivas que o tema admite, cumpre reforçar a atualidade do estudo dos problemas ético-jurídicos concernentes ao aborto. Como destaca

\footnotetext{
76 PAPALEO, Celso Cezar. Aborto e contracepção: atualidade e complexidade da questão. Rio de Janeiro: Renovar, 2000, p. 42.

${ }^{77}$ ENGELHARDT Jr., H. Tristam. Fundamentos da Bioética. São Paulo: Loyola, 2004, p.34.
} 
Celso Cezar Papaleo, a variedade de seus aspectos é inquestionável, sendo-lhe intrínseco o acento polêmico de sua discussão e as dissonâncias que seu exame provoca ${ }^{78}$.

Com isso, podemos afirmar que, do ponto de vista discursivo, o problema assume uma estrutura eminentemente dialógica. A compreensão da estrutura dialógica liga-se ao discurso racional ou fundamentante, que tem por postulado o dever de prova, sobre o qual falaremos mais adiante ${ }^{79}$.

Entre as várias possibilidades, poderíamos exemplificar com estudos que privilegiam: a) o problema de saúde pública, b) a questão dos direitos reprodutivos; c) aspectos penais do aborto; d) abordagem sociológica; e) problemas médicos e fisiológicos das práticas abortivas; f) questões psicológicas; g) enfoque sob a ótica das inúmeras religiões; h) status moral do feto de acordo com a filosofia do direito; i) debates morais em torno do aborto e o relativismo axiológico. Há outras, mas é bom não olvidar que, muitas vezes, há um entrelaçamento dessas perspectivas, de modo interdisciplinar.

Sendo patente a necessidade de delimitação do problema a ser analisado, sob o risco de restar prejudicada a cientificidade, destacamos que o estudo privilegiará os itens "h" e "i" acima especificados, sempre ressaltando os reflexos para o Direito. Primeiro, porém, será preciso delimitar algumas premissas, antes de avançarmos nas discussões sobre os debates relacionados à moralidade.

Especificamente, tomamos o conceito de pessoa como núcleo de nossas incursões na Filosofia do Direito. Procuraremos analisar por que todo celeuma em torno do início da vida biológica enseja conclusões que privilegiam um absolutismo moral, por nós rechaçado. Cumpre, no entanto, questionar se também o estabelecimento de um conceito de pessoa em termos filosóficos não padeceria do mesmo problema ou se, ao contrário, pode ser utilizado como um critério útil nas decisões sobre a interrupção da gravidez.

A lei não fornece um conceito de pessoa, restringindo-se a determinar o momento em que começa a personalidade jurídica (artigo $2^{\circ}$ do Código Civil) ${ }^{80}$. Mas nossa

\footnotetext{
78 PAPALEO, Celso Cezar. Aborto e contracepção: atualidade e complexidade da questão. Rio de Janeiro: Renovar, 2000, p. 17.

${ }^{79}$ Remetemos o leitor à nota de rodapé $\mathrm{n}^{\circ} 17$.

80 Há inúmeras polêmicas acerca da teoria adotada pelo Código Civil, destacando-se como correntes principais as teorias natalista e concepcionista, que admitem algumas variações entre os estudiosos. Não podemos esquecer, ademais, que o termo 'pessoa' compreende entes não humanos, que são sujeitos de direitos e obrigações, também. Em monografia aprofundada sobre a tutela civil do nascituro, Silmara J.A. Chinelato e Almeida destaca as inúmeras correntes doutrinárias existentes. Pondera sua posição eminetemente concepcionista, e escreve: "não há meia personalidade ou personalidade parcial. Mede-se ou quantifica-se a capacidade, não a personalidade. Por isso se afirma que a capacidade é a medida da personalidade" (Almeida, Silmara J. A. Chinelato e. Tutela civil do nascituro. São Paulo: Saraiva, 2000, p. 168).
} 
preocupação é delimitar o conceito tomando por base a filosofia jurídica e contribuições de outras áreas do conhecimento. Haveria razão para estender o conceito de pessoa ao feto? Há motivo para identificação dos termos homem e pessoa? Poderíamos considerar a "pessoa" somente em termos comunicacionais? O termo linguístico poderia ser compreendido em equiparação ao ser ontológico?

Além disso, ilustraremos os capítulos desse estudo com análises de algumas películas que abordam de forma profícua o problema do aborto, como maneira de aproximar e exemplificar a complexidade da temática.

Consideramos que a imagem é uma forma de linguagem, com uma estrutura própria, mas que também é capaz de problematizar, unindo elementos racionais (logos) e afetivos (pathos), instaurando uma espécie de racionalidade logopática, tal como define Julio Cabrera. Para o autor,

\footnotetext{
saber algo do ponto de vista logopático não consiste somente em ter "informações", mas também em estar aberto a certo tipo de experiência e em deixar-se afetar por uma coisa de dentro dela mesma, em uma experiência vivida. De forma que é preciso aceitar que parte deste saber não é dizível, não pode ser transmitido àquele que, por um ou outro motivo, não está em condições de ter as experiências correspondentes ${ }^{81}$.
}

Esse raciocínio compõe, indubitavelmente, uma das premissas desse trabalho, sendo primoroso o neologismo cunhado por Cabrera. Salientamos, no entanto, uma escolha terminológica ligeiramente diferente, que adotaremos ao nos referirmos a essa mesma ideia: em lugar de pático (pathos), preferimos o verbete Eros, por entendermos mais consonante com o que queremos expressar, considerando que há uma diferença entre os dois - verifica-se pela própria ideia de "patológico" que se liga ao primeiro.

No ensinamento de Lídia Reis de Almeida Prado,

Eros significa o desejo incoercível dos sentidos, o amor e - segundo Diotima, no Banquete de Platão - um demônio, ou seja, um intermediário entre os deuses e os homens. Como o Deus do amor, que está a meia distância entre uns e outros, ele preenche o vazio, tornando-se assim o elo que une o todo a si mesmo (...) em geral, o Eros é associado à afetividade, à intimidade, à capacidade de relacionamento, ao amor, ao vínculo, ao lúdico. Com o Logos costuma-se

${ }^{81}$ CABRERA, Julio. O cinema pensa: uma introdução à Filosofia através dos filmes. Rio de Janeiro: Rocco, 2006, p.21. 
relacionar a consciência focalizada, o respeito pelos fatos, o julgamento feito com base apenas na lei, o intelecto, a abstração lógica e a discriminação ${ }^{82}$.

Feito este adendo explicativo, é inegável que as discussões sobre o aborto apresentam, na maioria das vezes, um componente emocional muito forte, seja no que diz respeito aos dilemas vivenciados pela mãe, que decide interromper a gestação, seja quanto ao tratamento destinado ao feto, tanto por considerá-lo uma vida humana como pela personificação do ser ainda não nascido.

Ademais, Arte e Direito não estão apartados de modo abissal. Ao contrário, podem ser feitas inter-relações entre as duas linguagens: ora, o Direito, assim como o Cinema é, antes de tudo, um bem cultural. Como leciona Tércio Sampaio Ferraz Jr.,

para muitos, arte e ideal, justiça e idéia, enquanto algo oposto à realidade, parecem confundir-se. Uma espécie de inatingível, sempre a ser buscado e nunca definitivamente encontrado. A raridade entre ambas, contudo, não lhes retira uma consistência real, a realidade do sentido da existência humana. Afinal, onde não há arte, a vida se afunda na mesmice do cotidiano e onde não há justiça, a existência perde significado. Daí o sabor insosso do repetitivo, que mata a espontaneidade. Daí a amargura das injustiças que nunca se transfiguram $^{83}$.

Os filmes servirão como mote para apresentação de alguns temas que permearão este trabalho. Para tanto, escolhemos cinco películas: Regras da vida, O segredo de Vera Drake, 4 meses, 3 semanas e 2 dias, $O$ aborto dos outros e o breve documentário $O$ grito silencioso.

Todos abordam uma faceta interessante e peculiar desse objeto de estudo, e consideramos que uma análise desse cunho ajudará a compreender melhor o problema proposto. Não é só: podemos perquirir o problema da justiça e da moralidade em cada um deles. Como questiona Julio Cabrera, "por que as imagens não introduziriam

${ }^{82}$ PRADO, Lídia Reis de Almeida. O juiz e a emoção: aspectos da lógica da decisão judicial. Campinas: Millennium, 2008, pp.72-74. Conferir nota de rodapé 6. A autora alude aos termos Eros e Logos como potencialidades de todos os homens e mulheres por ocasião de aprofundamentos acerca dos arquétipos da anima (feminino) e do animus (masculino). Ambos são capazes de conviver em harmonia em homens e mulheres.

${ }^{83}$ FERRAZ Jr. Tércio Sampaio. O justo e o belo: notas sobre o direito e a arte, o senso de justiça e o gosto artístico. In: Estudos de Filosofia do Direito: reflexões sobre o poder, a liberdade, a justiça e o Direito. São Paulo: Atlas, 2009, p.276. 
problematizações filosóficas, tão contundentes, ou mais ainda, do que as veiculadas pela escrita?" 84.

Em termos científicos, aliar dois saberes que se inserem no universo da cultura pode trazer indagações acerca da própria possibilidade de relacionamento entre o Direito e o Cinema. Mas esta empreitada traz resultados extremamente satisfatórios para compreensão de um determinado objeto de estudo. É mister destacar que

esta relação existencial da arte, enquanto padrões historicamente constituídos, com o gosto artístico e da justiça, enquanto regras historicamente generalizadas, com a equidade, constitui para o conhecimento um desafio, mas não uma impossibilidade. O desafio está como situá-los como objeto cognoscitivo. $\mathrm{Ou}$ seja, como fazer frente a esta resistência à generalização que a ciência exige e ao relativismo ético em que se desemboca: o gosto como uma variável subjetiva, dependente dos padrões históricos, e o senso de justiça como variável subjetiva, dependente das regras ${ }^{85}$.

Para os objetivos da investigação proposta, elegemos como enfoque predominante o zetético-jurídico. A análise que privilegie a exegese dos diplomas legais pode ter um fim prático incontestável, mas não se coaduna com as indagações várias que circundam a decisão acerca da interrupção da gravidez, ou mesmo com o eventual questionamento acerca do que constitui o problema moral do aborto.

$\mathrm{O}$ enfoque zetético-jurídico acentua o elemento das indagações, e as questões apresentam um aspecto especulativo explicito ${ }^{86}$. Neste campo, insere-se a Filosofia do Direito, que se volta ao fenômeno jurídico, tomando-o como pilar das suas reflexões. Assim, importa ao estudioso o questionamento do objeto e das próprias premissas.

No entanto cabe destacar que o predomínio do enfoque zetético na pesquisa encetada não significa o abandono da perspectiva dogmático-jurídica. Ademais, este é um trabalho que não se descura da necessária interdisciplinaridade.

Feitas estas considerações metodológicas iniciais, é necessário estabelecer alguns parâmetros, pois o fato de os questionamentos serem abertos não significa que não exista

${ }^{84}$ CABRERA, Julio. O cinema pensa: uma introdução à Filosofia através dos filmes. Rio de Janeiro: Rocco, 2006, p. 17.

${ }^{85}$ FERRAZ Jr. Tércio Sampaio. O justo e o belo: notas sobre o direito e a arte, o senso de justiça e o gosto artístico. In: Estudos de Filosofia do Direito: reflexões sobre o poder, a liberdade, a justiça e o direito. São Paulo: Atlas, 2009, p. 276.

${ }^{86}$ FERRAZ Jr. Tércio Sampaio. Introdução ao estudo do Direito: técnica, decisão, dominação. São Paulo: Atlas, 1994, p. 39-47. Ver nota de rodapé $\mathrm{n}^{\circ} 11$. 
qualquer ponto de partida ${ }^{87}$. Neste passo, partimos da premissa de que a prática do aborto enraíza-se entre os mais diferentes povos, de modo que a ocorrência como fato social não pode ser negada: nos mais diversos lugares, épocas históricas, estratos sociais, colhem-se relatos até cotidianos de práticas abortivas.

Ocorre que, muitas vezes, a interrupção da gravidez é considerada como pressuposto fático que se subsume, em determinado ordenamento, a uma regra geral e abstrata proibitiva, com cominação de sanções - neste caso, o ato praticado é considerado um crime naquele ordenamento ${ }^{88}$.

Porém, onde quer que exista uma regra proibitiva, seria ingenuidade pensar na obediência universal do preceito estatuído, pelo que perderia a razão a própria norma. Deveras,

\begin{abstract}
se fosse inadmissível a possibilidade de uma oposição entre o que uma norma estatui como devendo ser e o que de fato acontece, se houvesse uma norma que apenas estatuísse como devido (devendo ser) aquilo que de antemão sabemos que, segundo uma lei natural, tem de acontecer, tal norma seria uma norma sem sentido, quer dizer, uma tal norma não seria considerada norma válida ${ }^{89}$.
\end{abstract}

Ora, preceituar algo que sempre acontece ou proibir algo que nunca ocorre acaba por esvaziar o sentido normativo na regulação de condutas. Seria o mesmo que regular, por meio da lei positiva, de modo contrário ou idêntico às leis naturais.

Desta maneira, mesmo nos países em que o aborto é proibido (ou permitido somente em casos excepcionalíssimos), ainda assim acaba sendo praticado pelos mais diferentes motivos ${ }^{90}$. Considerando que não se trata de um acontecimento incomum, surgem inúmeros movimentos favoráveis à descriminalização do aborto.

\footnotetext{
${ }^{87}$ Ibid., p. 42.

${ }^{88}$ KELSEN, Hans. Teoria Pura do Direito. São Paulo: Martins Fontes, 2009, p. 124. Para Kelsen, ao contrário do que tradicionalmente se compreende, a ação ou omissão será considerada ilícita por lhe ser ligada um ato coercitivo como consequência. Não é porque é ilícito que se liga ao ato ou omissão a sanção.

${ }^{89}$ Ibid., p. 237.

${ }^{90}$ SARMENTO, Daniel. Legalização do Aborto e Constituição. In: CAVALCANTE, Alcilene; XAVIER; Dulce (org). Em defesa da vida: aborto e direito humanos. São Paulo: Católicas pelo Direito de Decidir, 2006, p.112. Para o autor, a criminalização do aborto faz com que muitas mulheres, sobretudo as mais humildes, procurem por procedimentos clandestinos, perigosos, sem condições de segurança ou higiene.
} 
Ademais, como aponta Kelsen, "todos nós sabemos que a ilegalidade não coíbe a prática do aborto, mas exerce uma forte influência na relação entre as condições em que o aborto é praticado versus o status sócio-econômico da mulher" ${ }^{91}$.

Daí a expressão utilizada no subtítulo referente à "cultura do aborto", no sentido de ele ser uma prática que se verifica na sociedade de modo atemporal e difuso. Mudam-se os modos de praticá-lo, ou mesmo as razões, mas a interrupção voluntária da gravidez é um fato social e histórico.

Isso tudo traz a necessidade de discussão do problema, pois não se trata simplesmente de contrariar o disposto na lei, mas de questioná-la em termos de justiça ou injustiça, o que evidencia o relativismo axiológico subjacente aos debates em torno do assunto: não é por ser legal que a norma será necessariamente justa para todos.

Ademais, esses fatos recorrentes de interrupção da gravidez tornam evidente um aspecto peculiar das práticas abortivas proibidas, dessa "cultura do aborto" "92: sua clandestinidade.

Sobre o assunto, escreve Celso Cezar Papaleo que a

\begin{abstract}
clandestinidade abortiva é grave realidade entre nós e, praticamente, em todos os países da América Latina. No quadro da atual clandestinidade, embora a lei brasileira, dentre outras, puna até mesmo o auto-aborto, a mulher é comumente uma grande vítima das circunstâncias. Nessa clandestinidade, entretanto, melhor conseguem sair-se gestantes que, em alentada percentagem, dispõem de meios sócio-econômicos para ter filhos, que, todavia, não querem, enquanto outras, cujas múltiplas carências levam-nas a forçadas delivrances, pesa-lhes uma dupla condenação: a imposição social da gravidez exauriente e ameaçadora, ao lado das precárias provocações abortivas, sempre arriscadas, frequentemente perturbadoras e lesivas, até mesmo fatais ${ }^{93}$
\end{abstract}

De fato, a interrupção da gravidez, sem que seja nas modalidades permitidas pelo ordenamento jurídico, quase sempre se realiza sem segurança alguma para a gestante, com instrumentos obsoletos, quando não se baseia em receitas populares, o que aumenta o risco

${ }^{91}$ BACHA, Ângela Maria; GRASSIOTTO, Oswaldo da Rocha. Aspectos éticos das práticas abortivas. In: Bioética, v.2, n ${ }^{\circ} 1,1994$, p.54

${ }^{92}$ BOONIN, David. A defense of abortion. Cambridge: Cambridge University Press, 2003, p. 298. O autor, referindo-se especificamente à obra de João Paulo II (The Gospel of Life [Evangelium Vitae]), traz à colação um argumento antiaborto concernente ao fato de que as práticas permissivas contribuiriam para uma espécie de "cultura da morte". Não é este o sentido que utilizamos neste ponto. Aqui, não estamos analisando os argumentos favoráveis ou contrários ao aborto, mas somente concluindo sobre a prática social clandestina.

93 PAPALEO, Celso Cezar. Aborto e contracepção: atualidade e complexidade da questão. Rio de Janeiro: Renovar, 2000, p. 31. 
de óbitos de mulheres, ou mesmo traz sequelas irreversíveis, como a própria infertilidade. A clandestinidade acaba por relacionar-se, neste plano, com questões de saúde pública.

Obviamente, sendo uma prática contrária ao preceituado pelo Estado, quem recorre aos métodos abortivos o faz de modo a ocultar o que a lei considera um crime. Importa destacar a ocorrência de verdadeira rejeição, em termos de uma teoria pragmático-jurídica da comunicação.

Para compreensão da clandestinidade das condutas abortivas sob o enfoque da teoria pragmático-jurídica da comunicação, é necessário, pois, traçar algumas linhas sobre a posição dos interlocutores no discurso normativo, sobretudo no que concerne a reação do endereçado normativo à autoridade estatal, que estabelece as normas proibitivas.

Antes disso, consideremos uma breve explanação acerca da redefinição da maternidade e emergência dos direitos reprodutivos.

\subsection{O aborto provocado e a emergência dos direitos reprodutivos: o cerne} da decisão - a maternidade e suas redefinições.

É pertinente destacar que este estudo toma como centro dos debates o aborto provocado. As questões aqui apresentadas, relacionadas aos debates éticos, têm razão de ser, considerando a decisão de interromper a gravidez, como ato que parte da vontade de alguém. É dizer, em outras palavras, que o que tem relevância, aqui, pressupõe uma decisão direcionada a um fim. Quando nos referirmos ao aborto, é de se afastar, portanto, o aborto espontâneo, que ocorre por razões indiferentes à ação ou omissão humanas, em que o elemento volitivo é ausente.

Na definição médica,

aborto induzido é o nascimento induzido antes de 20 semanas (i.e., antes de o feto ser viável). Esse tipo de aborto refere-se à expulsão de um embrião ou de um feto que ocorre intencionalmente pelo uso de medicamentos ou de meios mecânicos 94 .

${ }^{94}$ MOORE, Keith; PERSAUD, T. V. Embriologia clínica. Rio de Janeiro: Elsevier, 2008, p. 23. Como salienta Jeff MacMahan, "não se sabe com certeza em que ponto da gestação o cérebro de um feto desenvolve a capacidade para gerar consciência. A maioria dos neurologistas aceita que o ponto mais precoce em que a consciência seria possível ocorre em torno da $20^{a}$ semana de gravidez, quando as conexões sinápticas entre os neurônios corticais começam a se formar. É improvável, no entanto, que a consciência se torne possível antes que tenha se passado plo menos mais um mês - ou seja, por volta do $6^{\circ}$ mês da gestação". Nesse sentido, consultar a obra: MACMAHAN, Jeff. A ética no ato de matar, Porto Alegre: Artmed, 2011, p. 282. 
Esta é a ideia utilizada quando nos referirmos ao aborto. Porém, a questão que surge, e que deve ser analisada, diz respeito à possibilidade de interrupção da gravidez contextualizando-a com a emergência dos direitos reprodutivos - que, apesar de não ser o foco desse trabalho, auxiliará na compreensão do tema.

$\mathrm{O}$ aborto provocado ganha novo matiz num cenário em que se discutem os direitos reprodutivos e a possibilidade de escolha que deveria ser conferida à mulher em continuar ou interromper a sua gestação, o que revela contornos de autodeterminação e mesmo de direito ao próprio corpo, com destaque às mudanças provocadas pelas tecnologias reprodutivas.

Antes disso, mas no caminho para conformação desse quadro, predominou na sociedade um desnivelamento social entre homens e mulheres, negando-se a elas direitos básicos que viriam depois a estampar bandeiras de luta de feministas e de outras mulheres contrárias à inferiorização jurídica e social, como uma forma de preconceito que foi denominado por muitos como forma de sexismo ${ }^{95}$.

A própria condição biológica atrelada à capacidade de gestar, de ser mãe, acabou definindo as ideias deterministas de que a gravidez é um sinal da sua própria natureza, que não pode ser renunciada, devendo a mulher simplesmente aceitar o fato e levá-lo adiante. Há ainda, além das limitações sociais e jurídicas, a "limitação biológica", inescapável, vista por muitos povos como uma dádiva divina, em contraposição à infertilidade.

Com os movimentos feministas e a luta pela igualdade de condições - ainda em avanço - começou a ser questionado o dogma da maternidade, redefinindo-a como um verdadeiro direito, atrelado à escolha, e não uma situação de condicionamentos inexoráveis e inquestionáveis. Verifica-se aí a conformação da ideia de direitos reprodutivos, com um significado mais amplo, a englobar não só o direito de ser mãe, mas também o direito de não o ser, isto é, a possibilidade de interromper a gravidez indesejada.

O aborto, nesse contexto, passou a ser compreendido como uma situação de escolha moral, que dignifica a mulher ao reclamar uma decisão. Isto é,

o tratamento social da maternidade provoca uma des-humanização das mulheres e da mesma maternidade. Já as considerações sobre o aborto as humanizam e podem ser, de fato, o momento de explicitação do maior respeito pela dignidade

\footnotetext{
${ }^{95}$ Peter Singer utiliza o termo ao abordar a questão do respeito aos animais, e o preconceito existente que toma por base a diferença entre as espécies, o que denomina de especismo.
} 
humana. Explico: a gravidez e a maternidade são vistas como o resultado 'natural' de um processo biológico em que não entram pensamento, emoção, relações, mas apenas a capacidade biológica das mulheres de gerarem. Porque a biologia no-lo permite, 'somos' mães. Reais ou potenciais. Já no caso do aborto, exige-se pensamento, decisão, escolha, capacidades eminentemente distintivas dos seres humanos. Tomam-se em conta as relações em questão e as consequiências reais do ato abortivo, para a mulher e para o seu entorno. Não é comum perguntar-se a uma mulher por que ela engravidou. Ou se pesou bem as conseqüências de seu ato de colocar no mundo mais um ser humano. Já no caso da decisão por um aborto, essas são as primeiras perguntas que se fazem. Pedem-se razões ${ }^{96}$.

Isto nos remete à velha definição de maternidade, que era um verdadeiro status da mulher. Como salienta Barbara Katz Rothman, ser mãe não era algo que as mulheres faziam, mas sim algo que eram, de modo que tudo o que as mulheres realizavam era considerado em termos de maternidade, ainda que potencial, como que inevitável para a maioria das mulheres ${ }^{97}$.

Nisso vislumbra-se que a procriação, como fato biológico, redefine-se, ao incorporar o elemento reflexivo, atinente à decisão consciente sobre o curso da gestação o que não é isento de críticas, alegando os opositores do 'direito ao próprio corpo' a necessidade de ponderação de interesses do feto, que é vida humana em desenvolvimento, e que não pode ser sacrificada por um interesse unilateral materno.

Alguns autores, como Elisabeth Badinter, ponderam que o amor materno não seria algo inato. Ao contrário, cuida-se de uma construção social, variável espaçotemporalmente, a ponto de a criança ser considerada em muitas ocasiões um verdadeiro estorvo, algo a ser descartado. Havia, não raro, atitudes de nítida rejeição, egoísmo e desprezo ${ }^{98}$. E ao passar do tempo, erigiu-se uma maternidade verdadeiramente forçada, necessária, sob pena de severa condenação moral ${ }^{99}$.

96 ROSADO-NUNES, Maria José. Aborto, maternidade e a dignidade da vida das mulheres. In: CAVAlCANTE, Alcilene; XAVIER; Dulce (org). Em defesa da vida: aborto e direito humanos. São Paulo: Católicas pelo Direito de Decidir, 2006, p. 31

${ }^{97}$ ROTHMAN, Barbara Katz. Recreating motherhood. Nova Iorque: Rutgers, 2000, p.7.

98 BADINTER, Elisabeth. Um amor conquistado: o mito do amor materno. Disponível em: http://www.fiocruz.br/redeblh/media/livrodigital\%20(pdf)\%20(rev).pdf. Acesso em 26 de agosto de 2011, pp. 15-17. As referências à paginação são realizadas considerando o arquivo no formato PDF. A obra oferece uma incursão histórica sobre a sociologia e psicologia das mudanças relacionadas aos papéis paterno e materno.

99 Ibid., pp. 141 e 170. "Enclausurada em seu papel de mãe, a mulher não mais poderá evitá-lo sob pena de condenação moral. Foi essa, durante muito tempo, uma causa importante das dificuldades do trabalho 
Relatando a indiferença materna, escreve Badinter que

\begin{abstract}
Ao buscar nos documentos históricos e literários a substância e a qualidade das relações entre a mãe e o filho, constatamos seja indiferença, sejam recomendações de frieza, e um aparente desinteresse pelo bebê que acaba de nascer. Esse último ponto é, com freqüência, assim interpretado: como seria possível interessar-se por um pequeno ser que tinha tantas possibilidades de morrer antes de um ano? A frieza dos pais, e da mãe em particular, serviria inconscientemente de couraça sentimental contra os grandes riscos de ver desaparecer o objeto de sua ternura. Em outras palavras: valia mais a pena não se apegar para não sofrer depois. Essa atitude teria sido a expressão perfeitamente normal do instinto de vida dos pais. Dada a taxa elevada de mortalidade infantil até fins do século XVIII, se a mãe se apegasse intensamente a cada um de seus bebês, sem dúvida morreria de dor ${ }^{100}$.
\end{abstract}

Ao final, conclui:

Ao se percorrer a história das atitudes maternas, nasce a convicção de que o instinto materno é um mito. Não encontramos nenhuma conduta universal e necessária da mãe. Ao contrário, constatamos a extrema variabilidade de seus sentimentos, segundo sua cultura, ambições ou frustrações. Como, então, não chegar à conclusão, mesmo que ela pareça cruel, de que o amor materno é apenas um sentimento e, como tal, essencialmente contingente? Esse sentimento pode existir ou não existir; ser e desaparecer. Mostrar-se forte ou frágil. Preferir um filho ou entregar-se a todos. Tudo depende da mãe, de sua história e da História. Não, não há uma lei universal nessa matéria, que escapa ao determinismo natural. $\mathrm{O}$ amor materno não é inerente às mulheres. É "adicional"101.

Mas a situação vai além. Com o despontar das novas técnicas reprodutivas, acentua-se com maior vigor a ideia de superação dos limites impostos pela natureza, de maneira que às mulheres que não conseguem gerar se disponibiliza uma ampla gama de modernas técnicas de reprodução assistida, que aumentam a cada dia as chances de sucesso gestacional.

feminino. A razão também do desprezo ou da piedade pelas mulheres que não tinham filhos, do opróbrio daquelas que não os queriam".

${ }^{100}$ Ibid., p. 57.

${ }^{101}$ Ibid., p. 266. 
Ser mãe, com base em todos esses aspectos, torna-se mais e mais questão de escolha, seja pelas possibilidades científicas que tornam viável a gestação, seja pelo desejo de não levar adiante a gravidez, interrompendo-a.

A maternidade deixa de ser um fato meramente biológico e, ao contrário das outras espécies animais, ganha um contorno moral.

Hoje, os direitos reprodutivos são alçados à condição de direitos humanos. Destaca Celso Cezar Papaleo que

em todos os países em que há, pelo menos, alguma liberdade de opinião e de luta, o movimento feminista reivindica o 'direito à reprodução', não a obrigatoriedade de reproduzir, que inferioriza a mulher na sociedade, coisifica-a a serviço do instinto, desprotegendo-a, cassando-lhe parte substancial da fruição da vida ${ }^{102}$.

Convém ressaltar que, em amplo estudo sobre a maternidade e as questões éticas que estão ao seu derredor, Barbara Katz Rothman salienta que, na América, ser mãe é condição que se enraíza a três ideologias principais: a) patriarcado, b) tecnologia e c) capitalismo. A primeira tem estreita relação com o sexismo, e os filhos são vistos como "do pai" ${ }^{103}$. Como metáfora do ato reprodutivo, o papel crucial é desempenhado pela célula gamética masculina, que é a semente plantada - o que espelha concepções antigas

102 PAPALEO, Celso Cezar. Aborto e contracepção: atualidade e complexidade da questão. Rio de Janeiro: Renovar, 2000, p. 39.

103 BADINTER, Elisabeth. Um amor conquistado: o mito do amor materno. Disponível em: http://www.fiocruz.br/redeblh/media/livrodigital\%20(pdf)\%20(rev).pdf, pp. 15 e 50. Acesso em 26 de agosto de 2011. "Por mais longe que remontemos na história da família ocidental, deparamos com o poder paterno que acompanha sempre a autoridade marital. A acreditar nos historiadores e nos juristas, essa dupla autoridade teria sua origem remota na Índia. Nos textos sagrados dos Vedas, Árias, Bramanas e Sutras, a família é considerada como um grupo religioso do qual o pai é o chefe. Como tal, ele tem funções essencialmente judiciárias: encarregado de velar pela boa conduta dos membros do grupo familiar (mulheres e crianças), é o único responsável pelas ações destes frente à sociedade global. Seu poderio exprime-se portanto, em primeiro lugar, por um direito absoluto de julgar e punir". A autora continua, explicando o longo período de domínio da figura paterna, e da redução da mulher a uma condição inferiorizada. Além disso, há a situação da criança e dos bebês, nem sempre vistos como algo bom, bem-vindo no seio familiar, o que poderia levar a atitudes de desespero que iam desde o infanticídio até ao abandono, sem distinção de classe social: "Os cuidados, a atenção e a fadiga que um bebê representa no lar nem sempre parecem agradar aos pais (...) Para os casais mais pobres da sociedade, o filho chega a ser uma ameaça à própria sobrevivência dos pais. Não lhes resta, portanto, outra escolha senão livrarem-se dele. Seja abandonando-o num orfanato, o que, como veremos, não lhe dá grandes possibilidades de sobrevivência, seja entregando-o à ama menos exigente possível, o que também não lhe aumenta muito a probabilidade de viver; ou seja, finalmente por uma série de comportamentos mais ou menos tolerados, que levavam a criança rapidamente para o cemitério 
acerca da teoria da pré-formação, em que os humanos eram percebidos como presentes, em miniatura, dentro do espermatozoide (homunculus) ${ }^{104}$.

Sob o enfoque de uma sociedade tecnológica, aplicamos ideias que se relacionam com máquinas às pessoas, que devem ser eficientes, produtivas, racionais e controladas. $\mathrm{O}$ próprio corpo é encarado como máquina, o que remete ao modelo cartesiano e ao dualismo alma/mente e corpo (mind-body dualism), e a maternidade é encarada como um trabalho, e os filhos, como produtos ${ }^{105}$. Por último, a abordagem capitalista da maternidade traduz-se como uma espécie de valoração do produto: nem todos são igualmente valiosos. Nesse ponto, conforme destaca Barbara K. Rothman, é nítido que os bebês brancos e saudáveis são produtos preciosos. Daí as expressões utilizadas pela autora: ocorre a "comodificação" (comodities) das crianças e a proletarização da maternidade ${ }^{106}$.

Então surge uma nova proposta acerca da visão que se tem sobre a maternidade, que é vista como uma relação entre mãe e feto, relação esta que não é somente químicobiológica, mas também social. O aborto, nesse sentido, é redefinido como a maneira de evitar com que o feto entre numa relação indesejada (unwanted relationship). A autora destaca, nesse ínterim, o processo de construção do feto, em que se observa uma fascinação cultural com o ser que, graças às modernas técnicas, pode ser alcançado e visto ainda no útero, que faz com que as pessoas olhem de modo diferente para uma mulher grávida, como que perquirindo em seu abdômen o próprio feto. De outro lado, ocorre a medicalização do aborto ${ }^{107}$.

Para Barbara K. Rothman, uma compreensão do aborto que se centre na mulher - o que ela defende - não tenderia a ver na interrupção da gravidez censura como usualmente ocorre. Qualquer que fosse a decisão, seja para encampar com todo vigor o papel social de ser mãe, seja a de não querer iniciar semelhante relação, seria igualmente aceita ${ }^{108}$.

Feitas essas considerações, importa analisar algumas outras premissas desse estudo, especialmente a relação entre o aborto e a teoria pragmático-jurídica da comunicação normativa, que amplia a compreensão acerca de um dos traços do aborto proibido: a sua clandestinidade.

\footnotetext{
${ }^{104}$ ROTHMAN, Barbara Katz. Recreating motherhood. Nova Iorque: Rutgers, 2000, pp. 15-26.

${ }^{105}$ Ibid., pp. 27-38.

${ }^{106}$ Ibid., pp. 39-50.

${ }^{107}$ Ibid., pp. 57-80.

${ }^{108}$ Ibid., p. 80.
} 


\subsection{A cultura do aborto sob o enfoque da teoria pragmático-jurídica da} comunicação

O Direito tem inegavelmente um componente linguístico, e é nas teorias da linguagem que se encontram os fundamentos de uma compreensão pragmático-normativa da comunicação. No entanto, como alerta Tércio Sampaio Ferraz Jr., o Direito não se reduz a uma dimensão linguística, havendo, por exemplo, as relações de força, instituições, conflitos de interesses, que não são linguagem ${ }^{109}$. A amplitude do fenômeno jurídico é bem maior do que a dimensão linguística.

A teoria pragmático-jurídica da comunicação pode ser tomada como um modelo teórico extremamente útil, na medida em que pode ser efetivamente aplicada em situações da realidade, de modo a auxiliar na compreensão de inúmeros fenômenos como rejeição, confirmação ou desconfirmação da autoridade estabelecida, no entendimento do poder como uma forma de relação que se constrói, ou mesmo em ocasiões em que se verificam comunicações abusivas ou defeituosas.

É inegável que o aborto, como uma situação de fato que se verifica na sociedade, pode também ser mais bem compreendido tomando por base as relações humanas estabelecidas na prática abortiva, especialmente aquelas marcadas pelo traço da clandestinidade.

Até mesmo alguns filmes podem ser analisados em função desses ensinamentos teóricos, a partir do momento em que tomamos as estruturas da linguagem imagética do cinema e apreendemos aquilo que é comunicado de forma crítica. Como lembra Julio Cabrera, num primeiro momento

\footnotetext{
pode ser assustador falar do cinema como uma forma de pensamento, assim como assustou o leitor de Heidegger inteirar-se de que 'a poesia pensa'. Mas o que é essencial na filosofia é o questionamento radical e o caráter hiperabrangente de suas considerações. Isto não é incompatível, ab initio, com uma apresentação "imagética" (por meio de imagens) de questões, e seria um preconceito pensar que existe uma incompatibilidade. Se houver, será preciso apresentar argumentos, porque não é uma questão óbvia ${ }^{110}$.
}

\footnotetext{
${ }^{109}$ FERRAZ Jr. Tércio Sampaio. Teoria da norma jurídica. Rio de Janeiro: Forense, 1978, pp. 5-8.

${ }^{110}$ CABRERA, Julio. O cinema pensa: uma introdução à Filosofia através dos filmes. Rio de Janeiro: Rocco, 2006, p. 17.
} 
Apreenderemos as nuances da teoria pragmática da comunicação normativa no momento em que os filmes forem analisados.

Antes disso, é necessário estabelecer como princípio que a comunicação é um fato humano (e inclusive não humano). É impossível não se comunicar, pois até mesmo o silêncio pode ser indicativo de uma comunicação.

Fala-se, pois, em três axiomas conjecturais da comunicação: 1) não existe uma não comunicação. O silêncio já é comunicação, por ser uma forma de dizer que não quer se comunicar; 2) a comunicação pode ser estabelecida de forma verbal e não verbal. A primeira, denominada digital, é peculiar do homem; a segunda, também chamada de comunicação analógica, é muito comum nas inter-relações entre seres humanos e animais, e diz respeito a gestos, postura corporal, tom de voz, expressão facial, forma de movimentação; 3) toda comunicação envolve a transmissão de um conteúdo e impõe um comportamento $^{111}$.

O modelo de uma pragmática da comunicação jurídico-normativa tem no seu centro o denominado princípio da interação ${ }^{112}$. Corroborando esta afirmação, destaca Mara Regina de Oliveira que

a pragmática jurídica preocupa-se, basicamente, com o chamado princípio da interação, na medida em que estuda o ato de se comunicar e a relação que se estabelece entre emissores (oradores) e receptores (ouvintes), mediada por signos lingüísticos (...) a comunicação está intimamente relacionada com o comportamento humano, pois este é sempre uma ação dirigida ao entendimento de outrem ${ }^{113}$.

Há, pois, na teoria pragmático-jurídica da comunicação, um viés relacional e interacional, que se assenta na capacidade de compreensão dos sujeitos participantes do discurso comunicativo, o que, como analisaremos adiante, acaba sendo considerado por alguns como uma característica própria da pessoa, e não simplesmente do homem,

111 OLIVEIRA, Mara Regina de. O desafio à autoridade da lei: a relação existente entre poder, obediência e subversão. Rio de Janeiro: Corifeu, 2006, pp. 85-86.

${ }^{112}$ FERRAZ Jr., Tércio Sampaio. Teoria da norma jurídica. Rio de Janeiro: Forense, 1978, p. 14. "Uma série de mensagens trocadas entre orador e ouvinte se chama interação. Toda situação comunicativa é, nestes termos, um sistema interacional".

113 OLIVEIRA, Mara Regina de. O desafio à autoridade da lei: a relação existente entre poder, obediência e subversão. Rio de Janeiro: Corifeu, 2006, pp.77-78. Ver também: FERRAZ Jr. Tércio Sampaio. Teoria da norma jurídica. Rio de Janeiro: Forense, 1978, p. 4. A obra selecionada é leitura imprescindível para quem deseja conhecer com mais profundidade esse modelo de investigação aplicado ao Direito. 
enquanto ser biológico. Poderíamos traçar alguma conclusão, com base nesse entendimento, sobre a impossibilidade de o feto figurar numa relação jurídica comunicacional, a ser estabelecida com a mãe, por exemplo?

A questão é polêmica, mas podemos afirmar que a situação comunicativa que se instala entre os sujeitos apela para a compreensibilidade da ação, relacionando-se com processos de ensino e aprendizagem, que se baseiam em um modelo de perguntas e $\operatorname{respostas}^{114}$.

Ademais, as relações estabelecidas são dinâmicas, de modo que as posições de cada interlocutor podem mudar. Só assim compreendemos que quem emite mensagens pode também recebê-las. As posições ocupadas por emissor e receptor são intercambiáveis, o que demonstra a reflexividade da relação ${ }^{115}$.

Poderíamos compreender o princípio da interação, portanto, a partir do comportamento consistente em uma troca de mensagens entre os sujeitos de uma relação, ou seja, entre emissor e receptor. Nesse sentido, comportamento é “"estar em situação'. Quem está em situação transmite mensagens, quer queira quer não. Comportar-se é estar em situação com os outros (...) é troca de mensagens, comunicação" 116.

Esclarecendo: quando se estabelece uma relação entre dois interlocutores, verificamos uma troca de mensagens. A mensagem que se transmite possui um determinado conteúdo, relacionado ao quê é transmitido ao ouvinte, e que se denomina de relato. Este é, pois, a informação transmitida.

Ocorre que a informação é passada de uma certa forma, de um modo que pode indicar que entre os sujeitos do discurso há uma simetria ou uma desigualdade de posições.

Há, além do conteúdo, uma informação sobre a informação, o que é denominado de cometimento, ou seja, "quem fala não transmite apenas uma informação (relato), mas transmite, ao mesmo tempo, como esta informação deve ser entendida (cometimento), isto é, quem fala informa e determina a relação entre si próprio e o seu ouvinte" ${ }^{117}$.

Como regra, ao emissor incumbirá o dever de prova daquilo que transmite. Diz-se que lhe compete fundamentar suas asserções, e o discurso lastreado por essa

\footnotetext{
${ }^{114}$ FERRAZ Jr., Tércio Sampaio. Teoria da norma jurídica. Rio de Janeiro: Forense, 1978, pp. 12-16.

115 OLIVEIRA, Mara Regina de. O desafio à autoridade da lei: a relação existente entre poder, obediência e subversão. Rio de Janeiro: Corifeu, 2006, p. 78.

${ }^{116}$ FERRAZ Jr., Tércio Sampaio. Introdução ao estudo do Direito: técnica, decisão, dominação. São Paulo: Atlas, 1994, p. 104.

${ }^{117}$ FERRAZ Jr., Tércio Sampaio. Teoria da norma jurídica. Rio de Janeiro: Forense, 1978, p. 31.
} 
fundamentação constitui um discurso racional ${ }^{118}$. O dever de prova faz com que aquilo que é dito submeta-se ao crivo do receptor, possibilitando eventual crítica. Do contrário, o escamoteamento do dever de prova torna o discurso irracional, afastando qualquer possibilidade de crítica ${ }^{119}$.

No desenvolvimento da teoria pragmática da comunicação normativa, fala-se também em algumas funções do discurso, referindo-se os autores a basicamente três: função sintomática, função de sinal e função estimativa, que se relacionam ao emissor, receptor e ao objeto do discurso.

A função sintomática diz respeito à comunicação, pelo emissor, de posições perante o receptor, como compreensão ou dúvida, alegria ou tristeza. A função de sinal verifica-se com relação ao receptor, como uma reação nele despertada. Por fim, quanto ao objeto do discurso, fala-se numa função estimativa, como uma espécie de convergência dos partícipes em relação à mensagem ${ }^{120}$.

Muitas vezes, porém, as interações não ocorrem de modo linear. Vezes haverá em que ocorrerá uma recusa na emissão de mensagem, ou mesmo no recebimento daquilo que se emite. Mas não é só. Existem situações peculiares em que as expectativas dos sujeitos também podem ser desiludidas no discurso, o que pode ensejar o surgimento de conflitos, conforme a postura que o receptor adote.

No primeiro caso, a recusa na emissão ou no recebimento de uma mensagem afeta, em última análise, a própria interação, basilar na pragmática jurídica. Esse fato é denominado de interrupção da situação comunicativa ${ }^{121}$. Já no segundo caso, que também demonstra a complexidade inerente ao discurso, há a desilusão das expectativas no que concerne ao comportamento do outro sujeito participante da interação. Nesta hipótese, pode ocorrer a adaptação ou a manutenção da expectativa desiludida, o que se denomina,

118 Ibid., pp. 16-18. Ensina Tércio: "Entendemos por racional o discurso fundamentante. Todo discurso, dissemos, apela ao entendimento de outrem. Nestes termos, discurso é ação linguística que pode ser aprendida, o que se mede na possibilidade despertada de ser repetida. Além disso, há discursos que não se negam a fundar o que se diz, que não impõem arbitrariamente a sua sustentabilidade, mas que fornecem instrumentos para sua comprovação. Portanto, discursos não apenas prováveis, mas com-prováveis. Esta comprovação depende do mútuo entendimento das partes que discutem, o que não significa que o caráter racional do discurso seja fruto de uma convenção (...) Discurso racional não é discurso fundamentado, nem mesmo fundamentável, mas fundamentante". Enfim, "no discurso racional tem de haver espaço para o questionamento que é outra regra básica que me permite falar em discurso fundamentante". É, pois, discurso aberto è exigência de fundamentação.

119 OLIVEIRA, Mara Regina de. O desafio à autoridade da lei: a relação existente entre poder, obediência e subversão. Rio de Janeiro: Corifeu, 2006, p.79.

${ }^{120}$ Ibid., p. 79.

${ }^{121}$ FERRAZ Jr., Tércio Sampaio. Teoria da norma jurídica. Rio de Janeiro: Forense, 1978, p. 39. Escreve o autor: "entendemos por interrupção a situação em que um dos comunicadores que, num dado momento é emissor, recusa-se a emitir a mensagem pedida ou em que um deles, sendo receptor, recusa-se a receber a mensagem enviada". 
respectivamente, de expectativa cognitiva e expectativa normativa. Os conflitos surgem quando ambos os sujeitos têm expectativas normativas, não adaptativas, o que faz com que recorram aos meios de resolução, que podem restringir-se a uma conciliação ou envolver o auxilio de um terceiro comunicador ${ }^{122}$, que institucionaliza o conflito e consegue pôr um fim nas divergências entre emissor e receptor.

É relevante destacar, portanto, que o terceiro comunicador não se submete ao dever de prova, adquirindo um status metacomplementar e "sua decisão passa a valer, independentemente de as expectativas dos endereçados serem, de fato, contrárias, valendo ainda que os endereçados insistam em desiludi-la"123. Agora, é mister destacar a atitude dos endereçados normativos em relação à autoridade constituída.

Em termos normativos, é possível apreender os aspectos relato e cometimento, ou seja, o conteúdo (objeto) e a relação complementar estabelecida entre a autoridade e sujeito, qualificando-se a conduta como permitida, proibida ou obrigatória. Essa relação poderá ser confirmada, desconfirmada ou rejeitada pelo sujeito, o que faz com que o emissor crie mecanismos capazes de evitar reações incompatíveis.

As possíveis atitudes podem ser englobadas em dois grupos: de reconhecimento ou não da autoridade:

confirmação é uma resposta pela qual o ouvinte aceita a definição (compreende e concorda); rejeição é uma resposta pela qual o ouvinte nega a definição (compreende e discorda); desconfirmação é uma resposta pela qual o ouvinte desqualifica (não compreende ou ignora). A diferença entre rejeição e desconfirmação está em que, na primeira, o ouvinte, de certo modo, reconhece o orador como autoridade, para depois recusar a definição, enquanto, na segunda, ele age como se o orador não existisse ${ }^{124}$.

Uma reação definida como metacomplementar não suporta a desconfirmação, que equivale ao aniquilamento da autoridade enquanto tal.

Para rejeitar, portanto, é necessário que primeiramente a autoridade seja reconhecida, pois a atitude contrária, ainda que furtiva, supõe logicamente a existência daquilo que se nega, o que não ocorre no caso da desconfirmação, pois nessa hipótese a

\footnotetext{
${ }^{122}$ Ibid., pp.41-43. Ensina o autor que "o comunicador normativo pode assumir diversas posições perante os demais. Isto se dá pela própria reflexidade do discurso que, tendo sido levado ao terceiro comunicador com o fito de evitar conflitos em larga escala, não elimina os conflitos, apenas os canaliza. Ou seja, a reflexidade (questão sobre a questão da questão, etc.) não se interrompe, mas se organiza".

${ }^{123}$ Ibid., p. 44.

${ }^{124}$ Ibid., p. 57.
} 
autoridade sequer é tida como existente: é ignorada, melhor dizendo. Portanto, admite-se em termos normativos a rejeição, nunca a desconfirmação.

Os mecanismos criados para evitar reações incompatíveis significam, portanto, confirmar a confirmação, rejeitar a rejeição e desconfirmar a desconfirmação. Com isso, a autoridade é mantida.

De fato, como escreve Tércio Sampaio Ferraz Jr.,

ao estabelecer uma norma, o editor, definindo a relação meta-complementar, já predetermina as suas próprias reações às eventuais reações do endereçado, em termos de confirmar uma eventual confirmação, rejeitar uma eventual rejeição e desconfirmar uma eventual desconfirmação ${ }^{125}$.

No que concerne ao aborto clandestino, como destacamos pouco acima, evidenciamos uma hipótese de rejeição da autoridade normativa. Isto porque quem recorre à prática abortiva de modo a escondê-la sabe que sua conduta seria qualificada como um crime perante a autoridade estatal, temendo as reações possíveis caso o aborto seja descoberto.

Por certo, reconhece-se a autoridade, que é mantida ao ser primariamente identificada. O aborto não é praticado às escâncaras, aos olhos de quem faz a persecução penal. Muito pelo contrário. A problemática surge porque a clandestinidade traz no seu rastro a precariedade com que o procedimento é feito, sem condições médico-sanitárias adequadas - sem contar possíveis complicações consequentes, advindas após o aborto, físicas e psicológicas.

Seria errado falar, no caso do aborto clandestino, em reação de desconfirmação da autoridade, pois nessa hipótese de reação do sujeito, não há ocultação alguma: a autoridade é desprestigiada e ignorada, como se fosse uma não autoridade:

a relação de autoridade se define pela garantia estabilizada de que certas garantias devem prevalecer, independentemente de o comportamento exigido ocorrer ou não. O importante para o cometimento normativo não é o cumprimento efetivo do relato (uma norma pode ser desobedecida e, apesar disso, a relação de autoridade permanece), mas a garantia de que reações que desqualificam a autoridade, com tal, estão excluídas da situação comunicativa.

${ }^{125}$ Ibid., p. 58. 
Isto quer dizer que a meta-complementaridade não se confunde com a imponibilidade dos comportamentos expressos no relato ${ }^{126}$.

A reação do editor normativo, no caso da rejeição, configura uma reafirmação da autoridade, nos termos da conduta que considera socialmente adequada - no caso, abstenção da conduta de interrupção da gestação. $\mathrm{O}$ entendimento dessa reação implica a verificação existente entre a conduta não desejada e a sanção cominada.

\section{4. $O$ aborto na cultura}

Feita a análise do aborto numa perspectiva de uma teoria pragmática da comunicação normativa, atentando ao que denominamos de cultura do aborto, como a prática clandestina que rejeita a autoridade normativa, convém examinar o modo como a temática aparece na cultura, especificamente de que maneira o cinema pode abordar e auxiliar na compreensão do problema, uma vez que também tal arte apresenta uma pluralidade de perspectivas.

Reafirmamos a possibilidade de estabelecer, através da imagem, uma forma de pensamento, em muitas ocasiões até mais efetiva que a própria escrita, partindo da premissa de que o cinema está intrinsecamente ligado a uma espécie de racionalidade "logopática"; além de uma estrutura lógica, tem um forte apelo afetivo, auxiliando na compreensão profunda de alguns dramas humanos.

A racionalidade logopática, por seu turno, liga-se aos denominados conceitosimagem, que estão presentes nos filmes e expressam de modo simbólico uma ideia ou ideias centrais, sempre considerando a experiência do cinema.

$\mathrm{Na}$ lição de Julio Cabrera,

os conceitos-imagem do cinema, por meio desta experiência instauradora e plena, procuram produzir em alguém (um alguém sempre muito indefinido) um impacto emocional que, ao mesmo tempo, diga algo a respeito do mundo, do ser humano, da natureza etc. e que tenha um valor cognitivo, persuasivo e argumentativo através de seu componente emocional $^{127}$.

\footnotetext{
${ }^{126}$ Ibid., p. 67.

${ }^{127}$ CABRERA, Julio. O cinema pensa: uma introdução à Filosofia através dos filmes. Rio de Janeiro: Rocco, 2006, p. 22.
} 
Nos filmes, podemos verificar alguns conceitos-imagem expressivos, que simbolizam mensagens transmitidas através da linguagem visual, de forma muitas vezes impactante. A clandestinidade, por exemplo, pode ser tomada como destaque em algumas películas que analisaremos. O conceito visual torna-se nítido, pois, independentemente da utilização da expressão "clandestinidade", a mensagem relacionada é transmitida.

A racionalidade venerada pela ciência não é a única faceta humana. $\mathrm{O}$ homem deve ser compreendido - e só tem condições de assim sê-lo - se considerar-se, para além da razão, um ser dotado de afetividade, e também de pulsões, o que constitui aquilo que Edgar Morin denomina de trindade psíquica. A própria racionalidade depende da afetividade para bem se desenvolver. "Tudo o que é humano comporta afetividade, inclusive a racionalidade". ${ }^{128}$

Engana-se o cientista que busca a pureza científica por meio de dados imparciais obtidos por um intelecto apurado à base da racionalidade. A carapuça da neutralidade não permite atingir nada além de uma radiografia da realidade, sem substância. Deveras, "a vida humana necessita da verificação empírica, da correção lógica, do exercício racional da argumentação. Mas precisa ser nutrida de sensibilidade e de imaginário" ${ }^{129}$. E a afetividade é a ponte de ligação entre o Homo sapiens e o Homo demens, termo que Morin cunha para designar as características que configuram aspectos da subjetividade, em meio a uma bipolaridade na qual se inserem as criações, entre o "caos genésico das profundezas psicoafetivas" e a "pequena chama de consciência". Há um mundo interior (98\% das vias cerebrais que nos regem) que não pode ser desprezado pelo contato de $2 \%$ que conecta o indíduo ao mundo exerior ${ }^{130}$.

Além do mais, o fato de a realidade constituir também uma construção reforça a possibilidade da analogia entre ficção e realidade. Como já assinalado, o mundo passa por nossa subjetividade, e não existe per se, sem a internalização. A realidade é resultado da interação humana, que é precariamente estabilizada, e cujos sentidos se estabelecem no intercâmbio comunicativo entre indivíduos. A comunicação, escreve Carlos María Cárcova, é um processo difícil e falível, devido à heterogeneidade existente entre emissores e receptores $^{131}$.

\footnotetext{
${ }^{128}$ MORIN, Edgar. O método 5: a humanidade da humanidade. Porto Alegre: Sulina, 2007, pp.119-120.

${ }^{129}$ Ibid., pp. 120-123.

${ }^{130}$ Ibid., pp. 125-131.

131 CÁRCOVA, Carlo María. Derecho y Narración. In: TRINDADE, André Karam; GUBERT, Roberta Magalhães; COPETTI NETO, Alfredo (org). Direito \& Literatura: ensaios críticos. Porto Alegre: Livraria do Advogado, 2008, p. 12.
} 
Análise e relação entre Arte e Direito podem ser encaradas de modo complementar e expansivo do entendimento de alguns dilemas - no sentido definido supra - e a própria aparição na Sétima Arte de alguns temas que interessam sobremaneira ao Direito, como o aborto, já indica um objeto comum de reflexão, o que não pode ser ignorado. Ambos, Cinema e Direito, são objetos da cultura, bens culturais que se voltam para seu próprio criador, a pessoa humana.

Nesse sentido, ressalta Mara Regina de Oliveira, que

este diálogo é o suporte de uma visão crítica que nos permite expandir, de forma muito criativa, nosso campo de reflexão da zetética jurídica, voltada para a análise específica do problema da justiça, que é uma das questões filosóficas centrais do pensamento jurídico crítico ${ }^{132}$.

Ademais, a respeito da inter-relação entre o justo e o belo, são oportunos os dizeres de Tércio Sampaio Ferraz Jr., ao postular que

em juízos estéticos, tanto quanto em juízos jurídicos, procede-se a uma escolha, e, conquanto esta seja sempre determinada por certa subjetividade e utilidade, em ambos os casos ela também decorre do fato de que o artista, como o julgador, observa o mundo das coisas como algo comum a todos. E aí se esconde algo mais que um interesse, uma vantagem ou uma desvantagem, que acompanha o juízo de utilidade e que exige do julgamento apenas uma correção consistente. A atividade do gosto estético, como a da justa decisão jurídica, exige um modo de pensar que não se satisfaz com a mera consistência, com o estar de acordo consigo mesmo ou com os objetivos visados, apanágio do juízo utilitariamente correto, pois exige uma capacidade de "pensar no lugar de todas as demais pessoas" $" 133$.

As películas, nessa linha de análise ao qual nos referimos ao invocar Morin, representam um verdadeiro alimento do psiquismo, uma fonte inesgotável de conhecimento sobre nós mesmos:

${ }^{132}$ OLIVEIRA, Mara Regina de. O mercador de Veneza e o problema da justiça. In: Revista brasileira de Filosofia, no 232, 2009, p.294. Há outras obras da autora que realizam a ligação entre o Direito e as formas de manifestação artística, especialmente o Cinema e o Teatro.

${ }^{133}$ FERRAZ Jr. Tércio Sampaio. O justo e o belo: notas sobre o direito e a arte, o senso de justiça e o gosto artístico. In: Estudos de Filosofia do Direito: reflexões sobre o poder, a liberdade, a justiça e o Direito. São Paulo: Atlas, 2009, pp. 274. 
Os filmes e as séries de televisão nos falam, sem parar, dos problemas da vida que são os amores, ambições, ciúmes, traições, doenças, encontros, acasos. São 'evasões' que nos fazem mergulhar em nossas almas e em nossas existências $^{134}$.

$\mathrm{O}$ entrecruzamento entre as teorias e as vivências projetadas, mais do que simples ilustração ou elucubração, serve de reflexão, ou seja, de questionamento e aprofundamento do real. "Encontramos no cinema, ao mesmo tempo, evasão e hiper-realidade." ${ }^{135} \mathrm{Na}$ lição de Morin, "os dois seres que coexistem em nós, do estado prosaico e o do estado poético, são o mesmo (...) a dominância da prosa contém instantes poéticos; a dominância da poesia contém instantes prosaicos"136, o que ensejaria a denominação de Homo complexus ${ }^{137}$.

Escolhemos cinco filmes/documentários que apresentam o problema do aborto, cada qual com destaque a determinado viés, que será sublinhado em cada análise. Julgamos essencial, para as considerações críticas, a transcrição de alguns diálogos ou frases, especialmente daquelas que encerram correlações com os pontos teóricos de abordagem desse trabalho.

Deveras, uma leitura dos filmes que se restrinja à descrição do enredo não pode ser de interesse científico, para uma proposta de construção de um saber interdisciplinar e integrativo da imagem visual e filosófica.

Neste capítulo inicial, principiaremos com a análise da película Regras da vida.

\subsection{Análise do filme Regras da vida}

O filme Regras da vida (The Cider House Rules), dirigido por Lasse Hallström, cuida, no seu enredo, de algumas questões que permeiam os debates referentes ao aborto. Trata-se de um filme de época, e muitos dos assuntos que se passam na vida das personagens poderiam ser transportados para o presente, o que revela a atualidade perene das causas e consequências humanas de um aborto.

\footnotetext{
${ }^{134}$ MORIN, Edgar. O método 5: a humanidade da humanidade. Porto Alegre: Sulina, 2007, pp. 134-135.

135 Ibid., p. 135.

136 Ibid., p. 138.

${ }^{137}$ Ibid., pp. 140-141. Escreve o autor que "o ser humano é bipolarizado entre demens e sapiens. Mais ainda, sapiens está em demens e demens está em sapiens, em yin yang, um contendo o outro. Entre ambos, antagônicos e complementares, não existe uma fronteira nítida; há, sobretudo, eflorescências da afetividade, da estética, da poesia, do mito. Uma vida totalmente racional, técnica e utilitária seria não apenas demente, mas inconcebível. Uma vida sem nenhuma racionalidade seria impossível. É a racionalidade que permite objetivar o mundo exterior e operar a relação cognitiva prática e técnica".
} 
O filme se passa na Nova Inglaterra, e é baseado na obra homônima escrita por John Irving. Apesar de ser uma película com inspiração literária, não há um "excesso narrativo", ou seja, a utilização desarrazoada de um narrador externo, que transmite o desenrolar dos acontecimentos. São as próprias personagens que, vez ou outra, relatam algo sobre a história.

O recorte cinematográfico ensejou o destaque da história de alguns personagens, embora preocupado com uma boa adaptação. Alguns hospitais e manicômicos de North Hampton, fechados na década de 1970, foram utilizados como locações para filmagem.

Vale salientar, antes de discorrermos sobre o enredo do filme, a publicação de um artigo, em coautoria com a Professora Orientadora desse trabalho, com o título "Regras da vida: uma reflexão fílmica sobre o relativismo moral relacionado à prática do aborto" ${ }^{138}$. A análise aqui realizada contém muitos dos elementos explorados no artigo, com algumas alterações.

Sobre a história, destacaremos somente aquilo que pertine ao aborto, deixando de lado considerações que se imbricam a outros assuntos abordados no filme. Não haverá, no entanto, prejuízo para o entendimento das discussões.

Especificamente, podemos citar a questão da adoção de crianças como uma das opções possíveis em detrimento da realização de um aborto o que ensejaria a proteção da vida, um modo de salvaguardar aqueles que ainda não nasceram, e nem nascerão com a interrupção da gravidez. Celia Wolf-Devine e Philip E. Devine criticam argumentos relacionados à igualdade e citam como possível solução aos abortos a adoção. Dizem que

os argumentos sobre a igualdade encontram dois problemas. Primeiro, eles negligenciam a solução que satisfaz ambos os interesses, da mulher e do feto adoção. Destruir nossa própria descendência em escala massiva, enquanto há mais de dois milhões de pais esperando para cuidar deles, é irracional. E, segundo, sem critérios claros e amplamente aceitos daquilo que se poderia denominar uma sociedade igualitária, eles ameaçam justificar o aborto indefinidamente (tradução nossa) ${ }^{139}$.

\footnotetext{
${ }^{138}$ Disponível em: http://www.ibdfam.org.br/?artigos\&artigo=732, Acesso em 08 de agosto de 2011.

139 TOOLEY, Michael; WOLF-DEVINE, Celia; DEVINE, Philip E; JAGGAR, Alison M. Abortion: three perspectives. New York: Oxford University Press, 2009, p. 98. Assim, no original: "Egalitarian arguments generally face two problems. First, they neglect the solution that satisfies both the interests of the woman and those of the unborn child - adoption. Destroying out our own offspring as we are doing on a massive scale, while there are more than two million would-be adoptive parents waiting to care for them, is irrational. And, second, without clear and widely accepted criteria for would count as an egalitarian society, they threaten to justify abortion indefinitely".
} 
Como contraponto, destaca-se que a ocorrência de gravidezes indesejadas, por razões várias, pode ser um fator de desestabilização emocional, uma forma de violência silenciosa. E, na confluência desses acontecimentos, tem-se o orfanato.

Em St. Cloud's, o orfanato é o cenário de realidades bem distintas, e até certo ponto complementares. Como se destaca no início da película, é o local aonde as pessoas vão por dois motivos: ou acrescentarão alguém em suas vidas (por meio da adoção), ou deixarão alguém para trás (para a adoção, ou pela interrupção da gravidez).

Neste cenário, nos é apresentado Homer Wells, criança que foi rejeitada mesmo após duas adoções, sendo devolvida ao orfanato onde crescerá sob os cuidados do Sr.Wilbur Larch - médico que, além de cuidar das crianças do orfanato, realiza partos e abortos -, e das enfermeiras que lá trabalham.

Ao crescer, Homer passa a acompanhar o médico nos atendimentos, e aprende a profissão com o mestre, ainda que de modo informal. É habilitado, pois, aos procedimentos de rotina, mas logo exsurge um dilema ético, representado pela recusa de Homer em realizar abortos. Não vê com bons olhos a prática da interrupção da gravidez. Mas o Dr. Larch, sempre tentando cultivar o interesse do jovem inclusive na realização de abortos, argumenta que tal procedimento é, na verdade, um modo de ajudar as mulheres que não encontram ajuda em nenhum outro lugar ${ }^{140}$. É interessante destacar que é a mesma expressão utilizada por Vera Drake, como veremos.

Homer tem consciência da ilegalidade, e a cita como um dos motivos para não praticar o aborto. Porém, ficam nítidas suas convicções contrárias, que não se resumem à ilegalidade da prática.

Numa das "visitas ao orfanato", nos são apresentados Candy e Wally. As crianças, que brincavam eufóricas na neve, ao presenciarem a aproximação do veículo, logo cercam o casal. Tornam-se sérias, e há esperança de uma possível adoção, contando as qualidades que as tornam dignas da escolha, em detrimento das outras. Algumas, já desiludidas, veem a visita com desalento: conheço os tipos, vão levar um dos bebês. Assim, fica assentada uma característica da adoção, que tem como referência as crianças menores e os bebês nota-se, aliás, que alguns poucos adolescentes não têm mais chances de conseguir um local. A imagem destaca por meio do close-up as expressões nas faces das crianças, os

\footnotetext{
${ }^{140}$ As falas destacadas foram retiradas dos filmes aos quais assistimos.
} 
sentimentos que elas transmitem e que sentimos. E, como destaca Bela Balacs, "os bons close-ups são líricos; é o coração, e não os olhos, que os percebe" ${ }^{\text {"141. }}$.

Neste ponto, é de se destacar que há, infelizmente, a preferência por padrões de crianças adotadas. Nem todas conseguem, havendo óbices de várias ordens - como a faixa etária. Este não é o objeto do nosso trabalho, mas por certo, a temática é rica, e possibilitaria um estudo próprio.

$\mathrm{O}$ isolamento do local faz com que as crianças se deslumbrem com o carro que chega, ávidas de curiosidade. E a diversão do cinema é o movimento que induz à fantasia: a esperança de uma mãe. No único filme projetado num aparelho antigo, King Kong nutre pela personagem feminina um amor que, para as crianças, é maternal: pensa que é a mãe dele, repetem. Mas sempre o filme é interrompido por problemas no projetor. Há uma projeção-identificação nítida, e as crianças refletem a necessidade de afeto do primata. Leciona Edgar Morin que

um primeiro e elementar processo de projeção-identificação vem, pois, conferir às imagens cinematográficas realidade suficiente para que as projeçõesidentificações ordinárias possam entrar em jogo. Por outras palavras, há um mecanismo de projeção-identificação na origem da percepção cinematográfica. Por outras palavras ainda, a participação subjetiva aproveita no cinematógrafo o caminho da reconstituição objetiva. Não possuímos contudo, ainda, bagagem suficiente para atacar de frente este problema essencial. Contornemo-lo provisoriamente, limitando-nos a verificar que a impressão de vida e de realidade própria das imagens cinematográficas é inseparável de um primeiro impulso de participação ${ }^{142}$.

Em outras ocasiões, a figura materna vem à tona, como com as indagações das crianças sobre a mãe do médico. Há um sentimento misturado, que esboça um ódio pelo abandono, uma mágoa que só seria apagada de uma forma: pela morte da mãe e do pai: às vezes eu gostaria de encontrá-los só para matá-los, diz um dos meninos do lugar.

Candy e Wally, no entanto, não estão lá para adotar. Logo se percebe que buscam o orfanato para fazer um aborto, que é realizado sem intercorrências.

Neste entremeio, uma nova moça chega ao lugar, mas sua situação é grave, pois procurara uma pessoa despreparada e incapacitada para a realização do aborto. O feto já

${ }^{141}$ BALACS, Bela. A face das coisas. In: XAVIER, Ismail (org). A experiência cinematográfica. Rio de Janeiro: Edições Gerais Graal, Embrafilmes, 1983, p. 91.

${ }^{142}$ Ibid., p. 151. 
havia sido expelido; entretanto, o útero estava perfurado com um objeto estranho que, pela suposição do Dr. Larch, seria uma agulha de crochê. Em tela, os métodos clandestinos, sem mínimas condições de higiene e salubridade, que permeiam a história do aborto proibido. Na ocasião, o médico responsável pelo orfanato aproveita para perguntar a Homer: se ela tivesse vindo até você há quatro meses e tivesse pedido por um simples aborto, o que você faria? Nada. É isso que significa não fazer nada. E aponta para a moça, sofrendo dores atrozes com a inflamação. Como desfecho desse caso, presenciamos o enterro da moça. Não havia o que ser feito.

Mais uma vez, podemos notar o debate entre o Dr. Larch (L) e Homer (H). L: Homer, se você espera que as pessoas sejam responsáveis pelos seus filhos, tem que dar a elas o direito de decidir se querem ou não estes filhos. H: Que tal esperar que eles sejam responsáveis por elas mesmas para começar? L: $O$ que me diz dessa criança? Esperava que ela fosse responsável? H: Eu falo dos adultos. Há, portanto, dois ângulos de análise do problema, quais sejam a dificuldade de os "órfãos" serem adotados, mas ainda assim estarem vivos, e a chance de terem terminado num incinerador, abortados. Arremata o médico: feliz por estar vivo sob qualquer circunstância. É isso que você pensa? Há nas ponderações de Homer, inegavelmente, um viés que se assenta no dogma da sacralidade da vida humana (sanctity-of-life doctrine), bem intangível, a ser preservado a qualquer custo. Esse debate pode ser dimensionado, em termos, na oposição posta por Celia Wolf-Devine e Philip E. Devine entre o comunitarismo e o individualismo. Para os autores, haveria uma verdadeira obrigação dos pais de cuidar dos fetos. Tem-se, no fundo, a ideia de responsabilidade parental pelo produto da concepção:

fetos e crianças são carentes de afeto por natureza. Os pais, deste modo, têm uma obrigação natural de cuidar daqueles que eles trazem ao mundo. Em situações extraordinárias, quando eles não podem fazê-lo, eles podem se desincumbir desta obrigação dando o bebê para o cuidado de pais adotivos, mas isso somente é aceitável em situações extremas (tradução nossa) ${ }^{143}$.

\footnotetext{
${ }^{143}$ TOOLEY, Michael; WOLF-DEVINE, Celia; DEVINE, Philip E; JAGGAR, Alison M. Abortion: three perspectives. New York: Oxford University Press, 2009, p. 94. "Fetuses and infants are needy and vulnerable by their nature, so bringing one into being through a voluntary act makes one responsible for meeting his or her needs. Parents, thus, have a natural obligation to care for those they brought into existence. In extraordinary situations where they are unable to do so, they can discharge their obligation by giving the baby at birth into the care of adoptive parents, but this is only morally acceptable in extreme circumstances".
} 
Por ocasião do retorno do casal para o local de origem, Homer aproveita e pega uma carona, desejoso de conhecer o mundo - até então restrito ao orfanato. Isto é visto com certa tristeza por Dr. Larch, que esperava tê-lo como médico do lugar, de certo modo, substituindo-o.

Então Homer parte com Candy e Wally, sendo-lhe oferecida a oportunidade de trabalhar na fazenda dirigida pela mãe de Wally. Assim, Homer junta-se aos serviçais na colheita de maçãs, que ocorre por temporadas. Nas épocas de entressafra, os trabalhadores partem para outros lugares, retornando no recomeço da colheita. Entre os colhedores, merecerão destaque, para o intuito desta análise, os familiares "Rose", pai (Sr. Rose) e filha (Rose Rose).

Com o retorno de Wally para lutar na guerra, ficam na fazenda a sua mãe, os trabalhadores da colheita e Homer, que recebe a visita frequente de Candy - por quem se apaixonará. Nesse período fora do orfanato, Homer conhece uma infinidade de novidades, nunca dantes sonhadas na restrição do local onde antes habitara. E relata, nas cartas que escreve acompanhadas das maçãs que envia, as nuances de suas novas experiências.

Durante a estadia de Homer na fazenda, algumas mudanças pairam no ar: querem substituir o Dr. Larch por alguém que não realize abortos. Na esperança de ver Homer ocupando seu posto, falsifica um diploma e, para convencer os responsáveis pela escolha do novo médico do lugar, satiriza, ironicamente, Homer, como missionário idiota. E a tática dá certo, pois acham que Homer é o médico ideal para o lugar. Entusiasmado, Dr. Larch envia uma maleta com instrumentos para Homer, e mais uma vez, a troca de correspondências deixa claras as posições divergentes dos dois médicos. H: Eu sei o que o senhor faz. Brinca de Deus. Matar ratos é o mais próximo do papel de Deus que quero chegar. L: Homer, aqui em St. Cloud's me foi dada a oportunidade de brincar de Deus ou deixar tudo entregue a sua própria sorte. Mulheres e homens deveriam agarrar este momento quando é possível brincar de Deus porque não terão muitos.

Após o recomeço da safra, os trabalhadores retornam como de costume, mas um episódio marca essa volta. A Sra. Rose Rose está diferente, o que denuncia seu vômito, seu enjoo e seu humor alterado. Não tarda para que Homer e Candy descubram que ela está grávida. O bebê, nas palavras expressas de Rose Rose, não é desejado, e é fruto de incesto. Seu próprio pai a engravidara. Apesar da ajuda que Homer oferece à moça, ela parece relutante, e teme a reação de seu pai. Mas, após o enfrentamento da triste circunstância, Homer se vê compelido à prática do aborto e, na situação delicada, tem de realizar aquilo que condena, dado o imenso sofrimento de Rose, relativizando todos os seus valores. 
Assim, toma a maleta com os instrumentos que recebeu do Dr. Larch e, utilizando dilatadores, curetas, fórceps, tampões e soluções ${ }^{144}$, interrompe a gravidez. Candy, que já praticara um aborto, relata a Rose as reações normais do procedimento, como o sangramento.

Um ponto de destaque no filme são as regras do alojamento em que moram os colhedores de maçã durante a safra (o que origina o nome do filme). São regras inócuas para quem não sabe ler, ou para alguém cuja vida se pauta por outras regras, por outras necessidades. Daí a conclusão dos trabalhadores: essas regras são um absurdo / alguém que não mora aqui criou essas regras/ elas não servem para nós/ temos de criar nossas próprias regras... e criamos todo santo dia.

De certo modo, poderíamos fazer um paralelo, ainda que moderado, acerca das proibições existentes a respeito das práticas abortivas. As regras não são criadas por quem vivencia o problema. São imposições externas, por excelência, e podem ser injustas, em muitos casos. Proibições que não se pautam na realidade fática, nas peculiaridades de caso a caso; regras desprovidas de sentido. Como destaca o próprio diretor, Regras da vida representa as regras que nos são impostas pelos outros, regras que são feitas pelos outros que sabem muito pouco sobre o nosso mundo.

Com o retorno de Wally da guerra, paralítico por conta de acidentes e doenças, Homer parte de volta para o orfanato, e de certo modo reinicia ou retoma seu caminho.

Mas não há, no filme, um fechamento conclusivo das situações existenciais. Deveras, escreve Cabrera que

os conceitos-imagem propiciam soluções lógicas, epistêmicas e moralmente abertas e problemáticas (às vezes acentuadamente amoralistas e negativas, mas, de qualquer forma, nunca estritamente afirmativas ou conciliadoras) para as questões filosóficas que aborda ${ }^{145}$.

Terminada a análise do filme Regras da vida, é preciso aprofundar algumas discussões sobre o que seja a Moral, e o embate entre relativismo e universalismo ético, e o modo como o aborto se insere nessas discussões. É inegável que as decisões sobre a

${ }^{144}$ Ibid., p. 134. Escreve Alison M. Jaggar que "nos Estados Unidos, em boa parte do século vinte, o método padrão do aborto realizado no primeiro trimestre era a curetagem aguda com instrumentos de metal, frequentemente chamados dilatação e curtetagem, ou D e C" (tradução nossa). No original: "for much of the twentieth century, the standard method of first-trimester abortion in the United States was sharp curettage with metal instruments, often called dilatation and curettage or D\&C".

${ }^{145}$ CABRERA, Julio. O cinema pensa: uma introdução à Filosofia através dos filmes. Rio de Janeiro: Rocco, 2006, p. 33. 
interrupção da gravidez podem ensejar ponderações de valores, cujo equacionamento mostra-se muitas vezes inconciliável. Mas há uma verdade hermenêutica a ser atingida? Se sim, como seria possível a indicação de valores absolutos?

A complexidade das questões reclama análise verticalizada, o que faremos a seguir. 


\section{CAPÍTULO 3. RELATIVISMO E UNIVERSALISMO MORAL: O PROBLEMA DO ABORTO}

Os dois valores opostos "bom e mau", "bem e mal" mantiveram durante milhares de anos um combate largo e terrivel, e ainda que há muito tempo que o segundo valor logrou vantagem, não faltam ainda hoje terrenos onde a luta continua indecisa (A genealogia da Moral, Friedrich Nietzsche)

Mesmo agentes conscientes e racionais que lidam diligentemente com a reflexão moral às vezes discordam de outras pessoas, igualmente conscientes (tradução nossa) ${ }^{146}$ (Principles of Biomedical Ethics, Tom Beauchamp e James Childress)

A moralidade. Seria simplório pensar que o problema moral em relação aos outros consiste em agir como se deveria agir, e o problema moral consigo mesmo é conseguir sentir o que se deveria sentir? Sou moral à medida que faço o que devo, e sinto como deveria? De repente a questão moral me parecia não apenas esmagadora, como extremamente mesquinha. $O$ problema moral, para que nos ajustássemos a ele, deveria ser simultaneamente menos exigente e maior. Pois como ideal é ao mesmo tempo pequeno $e$ inatingível. Pequeno, se se atinge: inatingível, porque nem ao menos se atinge. "O escândalo ainda é necessário, mas ai daquele por quem vem o escândalo" era o Novo Testamento que havia dito? A solução tinha que ser secreta. A ética da moral é mantê-la em segredo. A liberdade é um segredo (A Paixão Segundo G. H., Clarice Lispector)

Numa relação social, estabelecida entre os sujeitos de um discurso, eventualmente podem surgir discordâncias. Natural que essa possibilidade exista, em razão da própria complexidade e contingência que envolve estar numa relação, emitindo e recebendo mensagens.

Conviver é sujeitar-se não só a acordos, mas também a dissidências, o que reflete a própria diferença, a individualidade ideológica, e o pluralismo humano. Quando a

\footnotetext{
${ }^{146}$ No original: Even conscientious and reasonable moral agents who work diligently at moral reasoning sometimes disagree with other equally conscientious persons.
} 
controvérsia diz respeito a determinados preceitos considerados fundamentais pelos interlocutores da relação, poderá restar configurada uma divergência que se espraia na seara da Moral.

As discussões morais comumente envolvem conflitos de valores. Dissonâncias que podem ser resolvidas num determinado discurso comunicativo, ou permanecer insolúveis em dado contexto em que ambos os sujeitos mantêm a sua posição, refutando os valores diversos daqueles que propugna. Se a decisão não é institucionalizada, as diferenças permanecerão.

Resolver a celeuma pode não significar a eliminação do conflito, que permanecerá latente. É provável, inclusive, a mudança de opinião efetiva dos sujeitos, que podem inverter suas posições em relação aos princípios e valores noutra ocasião: no centro, a dinamicidade de uma relação comunicativa.

Por outro lado, quando se tem normas-princípios positivadas, estatuídas em uma Constituição, por exemplo, e que colidem num determinado caso, ou seja, cada qual albergando um fundamento importante a ser protegido pelo ordenamento, a harmonização poderá ocorrer pela ponderação casuística, tentando conciliar o que for possível, ou deixando prevalecer um dos sentidos de valor.

A bem da verdade, convém salientar, seria um contrassenso imaginar algum valor absoluto, pois valer é sempre relativo, conforme apreendemos em uma Teoria dos Valores.

Além disso, mesmo que haja uma tentativa de escalonamento e hierarquização de princípios ou fundamentos em uma determinada sociedade, é patente que não passará de uma discriminação contingente, variável, posto que é historicamente sedimentada e, portanto, mutável. Revoluções solapam uma ordem instituída e os valores e normas vigentes podem ceder lugar a outros, talvez mesmo contrapostos aos que sustentavam o grupo social até então dominante.

Assim, postas essas ideias e as relacionando ao objeto desse estudo, convém destacar uma verdadeira estrutura dialógica do discurso, que se verifica em termos racionais, sujeito ao dever de prova. E, na lição de Tércio Sampaio Ferraz Jr., o discurso fundamentante tem por alicerce três regras básicas: a) todo ato de falar pode ser posto em dúvida; b) uma ação linguística primária do orador não pode ser atacada pelo ouvinte, já que o orador pode defendê-la e c) o orador não poderá modificar suas ações linguísticas primárias. Escreve o autor que "a dialogicidade, como se vê, não pressupõe o princípio do 
terceiro excluído que exigiria, no caso, que todo ato de falar fosse ou atacável ou inatacável, o que feriria a primeira regra"147.

Ademais, vale salientar que o discurso dialógico assenta-se em topoi, lugares comuns, que dão abertura e flexibilidade à estrutura.

A estrutura dialógica opõe-se, portanto, à estrutura monológica do discurso, que pressupõe o princípio lógico do terceiro excluído, ocorrendo a divisão clara entre grupos opostos: atacáveis e inatacáveis, defensáveis e não defensáveis. Assim, pode-se dizer que

\footnotetext{
o discurso monológico, tendo um ponto de partida certo, admite axiomatização. O dialógico, sendo tópico, é sempre aberto e não axiomatizável, e como os topoi são fórmulas presas à situação comunicativa, o discurso dialógico experimenta certa historicidade $^{148}$.
}

Também Mara Regina de Oliveira salienta que os discursos racionais compõem-se dessas duas estruturas, e o predomínio de uma ou outra estrutura é determinado pela própria situação comunicativa $^{149}$.

Nos dilemas bioéticos não poderia ser diferente. A diversidade é facilmente verificável quando se põe a necessidade de uma decisão que envolva a vida e, no seu extremo, a morte.

Os discursos jurídicos não se axiomatizam, e uma quaestio certa pode se tornar uma quaestio dubia conforme a argumentação desenvolvida. Apresentam, pois, um caráter dogmático. Introduzem-se então as ideias de discussão-com (homologia, relação simétrica) e discussão-contra (heterologia, relação assimétrica). Nesse último caso, emissor e receptor trocam mensagens de forma partidária. "Por isso, as decisões não produzem verdades consensuais, mas absorvem a insegurança, tornando alternativas que em princípio são indecidíveis em alternativas decidíveis, que podem ser justificadas"150 .

Em relação ao aborto, as possibilidades de abordagens possíveis, bem como as conclusões a que chegam os estudiosos, já revelam essa multiplicidade de pensamentos em torno do assunto. Não há axiomatização possível. Reflexo de um enquadramento da Bioética contemporânea, que "é colocada diante de um fundo de considerável ceticismo,

\footnotetext{
${ }^{147}$ FERRAZ Jr. Tércio Sampaio. Teoria da norma jurídica. Rio de Janeiro: Forense, 1978, p. 21.

${ }^{148}$ Ibid., pp. 23-25.

149 OLIVEIRA, Mara Regina de. O desafio à autoridade da lei: a relação existente entre poder, obediência e subversão. Rio de Janeiro: Corifeu, 2006, p. 80.

${ }^{150}$ Ibid., p. 81
} 
perda de fé, convicções persistentes, pluralidade de visões morais e crescentes desafios das políticas públicas" $" 151$.

Entretanto, mesmo sendo a diversidade moral um fato verificável, há quem preconize que, para solução de determinada divergência entre padrões éticos dissonantes, haverá sempre a prevalência de determinados preceitos, "valores", entendimentos justos para a decisão. Esses sentidos a que apontam, e que devem prevalecer para esses pensadores, indicariam um universalismo. Entre as inúmeras possibilidades de decisão, algumas seriam sempre as corretas, pois consoantes a fundamentos prevalecentes.

O universalismo ético, portanto, coaduna-se com o pensamento de quem entende existirem direitos, princípios ou sentidos de ação que devem preponderar num caso crítico, em que a escolha deve ser feita, mesmo com algum eventual sacrifício: da diversidade humana seria possível extrair uma matriz ideológica informadora e sempre prevalecente.

Porém, quais são esses "valores", ou preceitos fundamentais? Como chegar à solução justa e quais os critérios que devem ser utilizados para identificar a decisão moralmente acertada?

A outros, contudo, não parece possível a eleição de preceitos incontrastáveis, sendo inviável delimitar a prevalência de princípios universais. A relatividade ditaria a tônica em cada caso. A escolha de sentidos absolutos representaria uma imposição arbitrária de determinado grupo, o que lhes parece inaceitável. Ademais, conjugar incontáveis valores morais reduzindo-os no momento decisório a um só poderia ensejar situações extremamente injustas, que não podem ser válidas para todos os lugares e povos.

Por outro lado, o relativismo teria o mérito de reforçar a tolerância entre as pessoas e sujeitos envolvidos num processo de escolhas, pois é contrário à imposição do que seriam os preceitos fundamentais.

Para alguns relativistas, como Gilbert Harman, de um modo global, as coisas em geral podem ser vistas de modo relativo, como o próprio movimento - que é sempre em relação a algum parâmetro tomado, um movimentar-se em relação a algo e, de acordo com a teoria da relatividade de Einstein, assim seria até quanto à massa de um objeto ${ }^{152}$. Seriam as ciências do espírito um reflexo do que pode ser verificado nas leis naturais, em que a mutabilidade das coisas reina?

${ }^{151}$ ENGELHARDT Jr., H. Tristam. Fundamentos da Bioética. São Paulo: Loyola, 2004, p. 31.

152 HARMAN, Gilbert; THOMSON, Judith Jarvis. Moral relativism and moral objectivity. Oxford: Blackwell, 2003, p. 3 . 
O embate instaura-se entre universalistas e relativistas, o que se observa com vigor em relação à temática do aborto: seja em relação àqueles que elegem a vida como bem absoluto, a ser respeitada em qualquer hipótese por ser um substrato lógico da pessoa humana, seja quanto aos que preconizam um outro valor incondicional, verificamos uma espécie de absolutismo. Por outro lado, o respeito às diferentes posições sinalizaria o relativismo bioético.

Mas se a vida é revestida pela característica da intangibilidade, não haveria sentido para discussão, pois sempre prevaleceria a decisão de se proibir a interrupção da gravidez, sendo impossível cogitar sobre hipóteses lícitas de abortamento, qualquer que fosse o caso, como na gravidez resultante de estupro - sob pena de ofender um bem absoluto.

De outro modo, se todas as posições podem ser defensáveis, se tudo, de certa forma, é válido, também se perderia o sentido dos debates, pois se tudo é possível, abortar ou não seria conduta indiferente. Poderíamos dizer que o relativismo moral conexiona-se à tolerância, ao passo que o universalismo seria sempre significaria uma imposição de valores?

Há outras consequências, como alerta Michael Tooley, que acentua a carga emocional nas discussões envolvendo o aborto. Partindo da possibilidade de formulação de juízos éticos sobre as práticas abortivas, pode-se pensar que, se o aborto for moralmente errado e a sociedade entender permissível a interrupção da gravidez, o resultado será a morte de muitos seres humanos inocentes. Por outro lado, se o aborto não for moralmente errado, mas a sociedade proibi-lo, considerando-o ilegal, também resultará em muito sofrimento, e na morte de muitas mulheres ${ }^{153}$, sendo que uma crença errônea traz como consequência, inexoravelmente, muitos malefícios. Mas essa formulação já não partiria da premissa de que existe uma resposta correta, coadunando-se com esquemas universalistas?

O raciocínio, porém, merece aprofundamento, sob o risco de revestir-se de um tratamento por demais simplista.

Impende destacar que, na raiz desses embates, situa-se o próprio sentido - ou sentidos - de justiça, que talvez se constitua como o tema mais fecundo da Filosofia do Direito. É perquirir se há, em cada grupo humano e em toda humanidade, uma ideia de justiça absoluta, ou se, ao contrário, o justo e o injusto não podem ser encontrados de modo universal.

${ }^{153}$ TOOLEY, Michael; WOLF-DEVINE, Célia; DEVINE, Philip E.; JAGGAR, Alison M. Abortion: three perspectives. New York: Oxford, 2009, p. 4. Como destacado, "discussões sobre a moralidade do aborto são frequentemente carregadas de muita emoção" (tradução nossa). No original: "discussions of the morality of abortion are often emotionally highly charged". 
Desde os antigos, as discussões sobre o que seja a justiça movem filósofos, havendo aqueles que buscam numa lei natural os valores do justo, como as várias correntes jusnaturalistas; ou numa ordem transcendental, que se refira a alguma entidade divina; ou por meio da razão; ou numa ordem normativa.

Em cada corrente filosófica as disparidades são imensas nas obras dos diversos autores que se debruçaram sobre o tema, com conclusões até mesmo contrárias entre si.

Assim, temos questões de ordem diversa: a) onde buscar a ideia de justiça?; b) há uma única ideia de justiça? Estas questões não são apartadas, revelando conexão patente. Uma outra indagação pode ser realizada: c) admitindo um valor do justo absoluto, seria possível aceitar ações contrárias o que se considera justo?

É curioso que, mesmo com toda diversidade cultural, social, econômica, histórica e ideológica, hodiernamente, tratados internacionais de direitos humanos tendem a inserir nos instrumentos assinados pelos países a ideia de um universalismo vitorioso, como reconhecimento de que há direitos universais, que devem ser reconhecidos e protegidos, pela só razão de pertencimento à espécie humana, o que costuma ser caracterizado, por outro lado, como uma postura ocidental.

Ora, por este ângulo de ideias, nas guerras e conquistas travadas pela humanidade, há sempre a superposição dos vencedores, que decidem os rumos a serem seguidos pelos dominados. Por analogia, seria possível falar em uma posição hegemônica dos direitos humanos, marcada pela cultura ocidental?

Num momento em que se fala em especificação dos sujeitos em direito internacional, em que as peculiaridades individuais ganham especial destaque e respeito, como nos diplomas que têm por sujeitos a mulher, a criança, refugiados, portadores de deficiências, como conciliar diferenças e um sentido universal de direitos a se proteger na ordem internacional? O pertencimento à espécie humana seria o fator a permitir a busca por direitos e bens universais? Não haveria contradição entre a salvaguarda multiculturalista e a busca por universalismo?

Pensar na existência de um sentido universal de preceitos e bens fundamentais, ou numa ideia de bem absoluto, pode ensejar consequências maniqueístas, pelo próprio princípio lógico que informa a dualidade implícita à escolha de um preceito fundamental. De fato, se o respeito à vida é alçado à condição suprema, como um bem, qualquer ofensa ou ação que possa mitigá-lo será considerada um mal.

Contudo, costuma-se estabelecer, ao lado de bens absolutos ou de situações a serem perseguidas e garantidas "pelo bem da humanidade", uma gradação de situações 
excepcionais possíveis. Mas concessões desse matiz desnaturam a própria noção universalista, por ser-lhe intrinsecamente incompatível.

Além disso, interessa tecer algumas considerações acerca das relações entre a Moral e o Direito, que há muito ensejam acirradas celeumas. Se por um lado há quem fale em mínimo ético no Direito, outros afastam Direito e Moral como ordens normativas distintas, que não podem ser confundidas. Verificar as possíveis relações entre Direito e Moral pode ter consequências para o próprio entendimento sobre as correntes universalista e relativista.

Neste ponto, os filmes, como podemos verificar, auxiliam na compreensão dos problemas morais que estão presentes na tomada de uma decisão. É o que se nota em $O$ segredo de Vera Drake e em 4 meses, 3 semanas e 2 dias, que serão analisados neste capítulo. Podemos destacar, de antemão, que as personagens também adotam determinadas posturas de acordo com aquilo que consideram relevante, mesmo que isto seja contrário ao que a sociedade aprova, como Vera Drake, cujos atos contrastam veementemente com a moral dominante de sua época, impregnada por valores cristãos, como se nota na importância da constituição familiar e na sacralidade da vida humana, inclusive intrauterina.

Especialmente no que concerne à teoria da interpretação, perquirir qual das normas a ser aplicada em determinado caso, por ser a mais justa ou correta, traz à colação considerações sobre a existência de uma verdade hermenêutica.

Ademais, ainda que introdutoriamente, cumpre esclarecer se há alguma diferença essencial entre os termos Ética, Moral, e Moralidade, usualmente utilizados como autorreferenciáveis, ou mesmo como sinônimos.

Como se vê, o estudo sobre relativismo e universalismo moral é muito complexo, e demanda análise mais detida, especialmente quanto aos argumentos utilizados por uma e outra corrente, a justificar o pensamento; há muitos questionamentos.

Buscar saber se há juízos éticos que podem ser considerados corretos (universalismo, objetividade moral) ou não (relativismo) é tarefa a cargo de uma "metaética"154.

No entanto, essa abstração teórica só fará sentido se a problematização for aplicável a uma questão prática, o que se verifica nas inúmeras ocasiões em que uma decisão deve ser tomada, como no caso do aborto. De nada adianta perquirir sobre as inúmeras teorias

${ }^{154}$ HARMAN, Gilbert; THOMSON, Judith Jarvis. Moral relativism and moral objectivity. Oxford: Blackwell, 2003, p. ix. 
que pairam em torno de alguma controvérsia ética se não for possível minimamente uma ampliação construtiva dos debates.

Essas ponderações realçam também a necessidade de tomar os valores sob uma perspectiva crítica. Quer consideremos a prevalência de uma postura relativista, quer uma universalista, estaremos diante de preceitos que determinado grupo social considera como relevante ou, ao contrário, nefasto, ruim, mal. Ante essa constatação, convém indagar de onde vêm tais valores e por qual motivo são assim considerados, bem como as circunstâncias em que determinada moral ganhou corpo.

Por esta razão, propõe Nietzsche uma crítica dos valores morais, mas, conforme preconiza o filósofo,

antes de tudo deve-se discutir o 'valor destes valores', e por isso é de toda a necessidade conhecer as condições e o meio ambiente em que nasceram, em que se desenvolveram e deformaram (a moral como conseqüência, como máscara, como hipocrisia, como enfermidade ou como equívoco e também a moral como causa, remédio, estimulante, freio ou veneno), um conhecimento de tal espécie nunca teve outro semelhante, nem é possível que não o tenha nunca desejado. $^{155}$

Essa proposta pressupõe o abandono de uma atitude meramente contemplativa, impondo-se a reflexão.

É necessário, também, sistematizar as discussões, o que militará em favor da compreensão. Não temos a pretensão de esgotar o tema, que renderia estudo próprio. Porém, discorrer sobre o aborto, especificamente sobre a relevância que o conceito de pessoa tenha em comparação ao direito à vida, sempre colacionado às discussões, é tratar também de formas de abordagens universalistas e relativistas.

A análise de algumas películas, neste capítulo, auxiliará na abordagem das discussões sobre relativismo e universalismo axiológico. De fato, inegável que os problemas trazidos nos filmes são, antes de tudo, problemas humanos, em que as controvérsias se instalam. Evidenciam, de modo sensível, as abstrações teóricas que perpassam os estudos sobre Ética e Moral, constituindo um efetivo instrumento para uma forma de pensamento capaz de conduzir a reflexões e, mais do que isso, têm um sentido prático.

${ }^{155}$ NIETZSCHE, Friedrich. A genealogia da Moral. Petrópolis: Vozes, 2009, p.28. 
Como pudemos verificar no primeiro capítulo, por meio de imagens, forma específica de linguagem, questões filosóficas podem ser analisadas de modo tão ou mais contundente do que a linguagem escrita. Isto pelo fato de, nessa forma de expressão e construção do conhecimento, estar presente o elemento afetivo, que aproxima os dramas reais às vivências do interlocutor, sendo capaz de sensibilizá-lo. Desta maneira, o entrosamento da Filosofia do Direito com o cinema é extremamente efetivo para compreensão dos temas relacionados à moralidade e à justiça. Mais uma vez, dialogam o justo e o belo.

Pelo cinema, há sempre uma aproximação com as questões aventadas, seja por projeção-identificação, seja pelas formas como a emoção é trabalhada. Muitas vezes - o que é mais interessante - aos problemas abordados não se dá uma solução definitiva, possibilitando uma integração de sentido a ser realizada pelo espectador, consoante suas próprias valorações.

Antes de adentrarmos nas especificidades de cada vertente axiológica, é mister traçar os contornos sobre as concepções de "valor", pois é inegável que vivemos circundados por valores. E, nas raízes das discussões entre universalismo e relativismo, situam-se as várias teorias sobre os valores, que podem ser tomadas como precedentes dos debates atuais.

\subsection{Um mundo de valores}

Escolher é optar, selecionar, eleger. Estamos circundados pela necessidade de decidir, uma contingência que se revela a todo instante pela só razão de convivermos, nas concessões que devem ser feitas, nas consequências legais advindas de uma ou outra conduta.

E, se por alguma razão alguém se abstém de opinar em determinada situação, de modo indireto se posiciona perante os outros, na situação comunicativa, de modo que é impossível uma pretensa neutralidade. Por analogia a um dos postulados teóricos da teoria pragmático-jurídica da comunicação, segundo o qual é impossível não se comunicar, poderíamos dizer que é impossível não valorar, permanecendo indiferente às situações em que estamos envolvidos.

Como escreve Ortega Y Gasset, 
a fatalidade com que deparamos ao entrar neste mundo - o mundo é sempre este, este de agora - consiste no contrário. Em vez de nos ser imposta uma trajetória, nos são impostas várias, o que, consequentemente, nos força... a escolher. É surpreendente a condição de nossa vida! Viver é sentir-se fatalmente forçado a exercer a liberdade, a decidir o que vamos ser neste mundo. Não há um momento de descanso para nossa atividade de decisão. Inclusive quando, desesperados, nos abandonamos à sorte, decidimos não decidir ${ }^{156}$.

As razões das escolhas que fazemos são inúmeras, com variáveis que sequer nos atrevemos a relacionar. Nem é objeto deste capítulo as possíveis discussões acerca da liberdade, que se conecta às escolhas que fazemos.

Como escrevem Marco Segre e Cláudio Cohen, citando Rokeach, "os valores podem expressar os sentimentos e o propósito de nossas vidas, tornando-se muitas vezes a base de nossas lutas e dos nossos compromissos" ${ }^{157}$. Deveras, o homem nasce, é educado e, de repente, vê-se uma pessoa buscando alguma coisa, evitando outras, abandonando concepções que nutriam os objetivos iniciais, ou retornando às convicções perdidas. Dinamicamente.

Em verdade, a definição do que seja valor não é tarefa simples. Mesmo que haja intuição sobre o que representam os valores, é difícil precisar um conceito ou significação. Não é por outra razão que, como salienta Reale, "há impossibilidade de defini-lo segundo as exigências lógico-formais de gênero próximo e de diferença específica" ${ }^{\text {"158 }}$. Simplesmente, e mesmo que incidamos em pleonasmo, diz-se que o valor vale, pertencendo os valores à ordem do dever-ser, sem que isso signifique um abismo absoluto entre os valores e a realidade (ser), havendo uma implicação mútua.

Para Goffredo, "valor de uma coisa é a importância dela entre outras coisas. É o mais, ou o menos, ou a equipolência (equivalência) de uma coisa em relação a outra ou outras. É o grau de "merecimento", o mérito da coisa, comparada com outras "159.

E destaca Tércio Sampaio Ferraz Jr. que a ideia de valor, antes de ser propriamente filosófica, tem origem econômica.

\footnotetext{
${ }^{156}$ ORTEGA Y GASSET, José. A rebelião das massas. São Paulo: Martins Fontes, 2007, p.78.

${ }^{157}$ COHEN, Cláudio; SEGRE, Marco. Definição de valores, moral eticidade e ética. In: COHEN, Cláudio (org). Bioética. São Paulo: Edusp, 1999, p. 15.

${ }^{158}$ REALE, Miguel. Filosofia do Direito. São Paulo: Saraiva, 1982, p. 187.

159 TELLES Júnior. Goffredo. O Direito Quântico: ensaio sobre o fundamento da ordem jurídica. São Paulo: Max Limonad, [19--], pp. 204-205.
} 
$\mathrm{Na}$ filosofia, ela entra por meio da chamada filosofia dos valores, para a qual estes são entidades (objetos) diferentes dos objetos reais, dos quais se dizem que são (no sentido de forma essencial e existência), ao passo que os valores valem (sua forma essencial não é um ser, mas um dever-ser, e sua existência se expressa por sua validade). O ser é, o valor vale, é sua fórmula consagrada ${ }^{160}$.

A noção de valores está intrinsecamente ligada às discussões sobre o aborto. Desde sempre, o começo e o fim da vida humana representam para a humanidade fatos valorados segundo a cultura dos mais diferentes povos, o que se depreende da análise das descrições fornecidas pela antropologia sobre ritos fúnebres, ou mesmo da compreensão acerca da concepção de um novo ser: o nascimento e a morte são marcos que geralmente delimitam a vida de um sujeito e, mais do que isso, sua existência.

O homem é o único animal que consegue valorar. Talvez as noções que verificamos entre outros animais sobre uma situação que seja ruim, comparada com outra, boa, seja mesmo reflexo de seu instinto, e não algo racional, com estimativa de seu próprio passado e futuro. No máximo, poderíamos conjecturar sobre experiências condicionadas - como evitar a dor, conseguir alimento e refúgio etc.

Destaco que não se trata de, com essa constatação, estabelecer qualquer juízo de inferioridade entre as espécies, ou justificar a diferença entre o tratamento de animais meramente sencientes em comparação com outros, autoconscientes (homem) ${ }^{161}$. Apenas se quer argumentar que a possibilidade de realização de juízos valorativos é eminentemente uma característica da pessoa humana.

Recorrendo à teoria dos valores, é possível estabelecer algumas características ou qualidades que estariam presentes quando se trata de um valor. Entre tais qualidades, costumam ser citadas a bipolaridade, a implicação, a referibilidade, a preferibilidade, incomensurabilidade, graduação hierárquica, a objetividade e absoluteza, a realizabilidade e, finalmente, a inexauribilidade ${ }^{162}$. Convém traçar breves linhas sobre cada uma delas.

Segundo a condição da bipolaridade, um valor enseja considerações sobre seu oposto, ou seja, um desvalor. Nesse caso, se determinada conduta é apreciada como boa, há em contrapartida uma conduta que seja avaliada como má, sendo que a existência de um

\footnotetext{
${ }^{160}$ FERRAZ Jr. Tércio Sampaio. Introdução ao estudo do Direito: técnica, decisão, dominação. São Paulo: Atlas, 1994, p. 179.

${ }^{161}$ SINGER, Peter. Ética prática. São Paulo: Martins Fontes, 2002, p. 84 . O autor, com base no princípio da igual consideração dos interesses, estabelece em sua linha argumentativa uma contraposição aos argumentos que alçam a espécie humana acima das outras espécies animais.

${ }^{162}$ REALE, Miguel. Filosofia do Direito. São Paulo: Saraiva, 1982, pp. 189-207.
} 
pressupõe a do outro. Por certo, há uma inter-relação que não pode ser ignorada, e um somente é em razão da existência do outro.

Essa bipolaridade diz respeito, portanto, à existência de vetores distintos numa avaliação. Porém, convém salientar, uma dada situação concreta poderá ser considerada de modo diverso pelos sujeitos que a apreendem. Essa qualidade dos valores, como se observa, não implica necessariamente que uma situação seja em si boa ou má, mas apenas pode ser, num determinado cenário, assim considerado. E mudanças podem ocorrer conforme modifica a sociedade e se alteram os valores fundantes. No que diz respeito à relação entre essa característica dos valores e o Direito, leciona Miguel Reale que

a dinâmica do direito resulta, aliás, dessa polaridade estimativa, por ser o direito a concretização de elementos axiológicos: - há o "direito" e o "torto", o lícito e o ilícito. A dialeticidade que anima a vida jurídica, em todos os seus campos, reflete a bipolaridade dos valores que a informam ${ }^{163}$.

Enfim, um determinado valor é compreendido aos pares, em conjunto com o seu desvalor. Porém, um e outro numa determinada localidade é mutável, não havendo que se falar em um sentido absoluto para o valor em contraposição ao seu par desvalorado.

Outra característica ou qualidade atinente aos valores é a implicação recíproca. Assim, eles não são nunca isoláveis e solitários. Ao contrário, podemos dizer que a constelação de valores existentes implica-se mutuamente. Com isso, é possível afirmar que há influências recíprocas, o que se relaciona à denominada força expansiva e absorvente dos valores e à solidariedade ética, devendo ser lembrado, ainda, que os valores contrapõem-se ao fato, ao dado. Porém, como destacado por Miguel Reale, ainda que o valor pressuponha o fato como condição de realizabilidade, acaba por transcendê-lo ${ }^{164}$.

Valorar é também estabelecer relações. Nesse sentido, diz-se que há uma referibilidade, ou seja, há uma tomada de posição e uma referência do valor para algo. $\mathrm{O}$ que conta é sempre no sentido de algo e para alguém.

A nossa vida não é espiritualmente senão uma vivência perene de valores. Viver é tomar posição perante valores e integrá-los em nosso "mundo", aperfeiçoando nossa personalidade na medida em que damos valor às coisas, aos outros

\footnotetext{
163 Ibid., p. 189.

${ }^{164}$ Ibid., p. 190. É importante lembrar, neste ponto, que o autor desenvolve com mais aprofundamento, em outros estudos, as relações entre fato e valor. Especificamente, há de ser lembrada a teoria tridimensional.
} 
homens e a nós mesmos. Só o homem é capaz de valores, e somente em razão do homem a realidade axiológica é possível ${ }^{165}$.

É por isso que dizer que uma norma é válida, nesse sentido, implica o estabelecimento de relações: ela é válida em relação a algo, havendo sempre um parâmetro de referência. Como ensina Tércio ao tratar sobre o problema da validade, a princípio os valores ostentam uma relatividade.

Por sua origem econômica, os valores são, em princípio, relacionais: como o dinheiro para os valores econômicos, também os valores em geral são medidos, submetidos a padrões, valem mais ou menos. Daí, a princípio, sua relatividade (o que trouxe para a filosofia o problema da afirmação de valores absolutos, noção em si contraditória e cuja busca gera a angústia que antes mencionamos ao falar do direito natural - item 4.2.6). De algum modo, porém, desta relatividade segue o caráter relacional da validade: valer é sempre valer-para algo ${ }^{166}$.

A tomada de posição imbrica-se com a necessidade constante de decidir, e decidir, em última instância, é escolher. O Direito está sempre às voltas com a necessidade de decidir. E pode ocorrer que o legislador antecipe algumas posições, restringindo as possibilidades de opção dos destinatários do comando, ou possibilite que a liberdade perante a norma apresente um campo de escolha. Mas a cadeia de decisões é contínua.

Outra qualidade dos valores, que se relaciona também com a tomada de posições dos sujeitos morais, é a preferibilidade. Quem valora e faz considerações sobre alguma coisa de certo modo procede de acordo com suas preferências, arraigadas na sua própria existência. Se algo é melhor ou pior, será em razão de uma afetação subjetiva, porventura estabelecida pelo próprio grupo social do qual a pessoa faz parte.

Correlacionado à preferibilidade, situa-se a possibilidade de hierarquização dos valores. Em tese, seria possível sistematizá-los hierarquicamente numa dada sociedade, ou mesmo de acordo com as preferências valorativas de determinado indivíduo. Porém, apesar de possível, é tarefa de grande monta, de difícil realização, mormente considerando a mutabilidade e dinâmica de valores no tempo e espaço. Com base nisso, no máximo é admissível falar em hierarquias provisórias e precárias de valorações.

${ }^{165}$ Ibid., pp. 190-191. Diríamos, nesse passo, que só a pessoa é capaz de valores.

166 FERRAZ Jr. Tércio Sampaio. Introdução ao estudo do Direito: técnica, decisão, dominação. São Paulo: Atlas, 1994, p. 179-180. 
O ser humano constrói-se a cada dia. Paulatinamente, reinventa-se e suas concepções anteriormente estruturadas cedem espaço a outras tantas. Pensar em uma lista de valores, eternos, parece um tanto irrealizável.

Contudo, mesmo diante dessa variabilidade axiológica, que dificulta o estabelecimento de uma hierarquização, há quem vislumbre um valor-fonte irredutível, máximo, em qualquer época ou sociedade humana. Assim,

\begin{abstract}
é possível haver uma ordenação do valioso, não de forma absoluta, mas nos ciclos culturais que representam a história humana, sendo certo, outrossim, que existe algo constante no mundo das estimativas, algo que condiciona o processo histórico como categoria axiológica fundamental, que é o homem mesmo visto como valor ou fonte espiritual de toda a experiência axiológica ${ }^{167}$.
\end{abstract}

Não se trata, portanto, do homem meramente biológico este valor-fonte, e sim da pessoa. Mas, nas discussões bioéticas, é com frequência que se vê a elevação da importância do homem biológico, da necessidade de proteção da vida humana, como substrato lógico da pessoa, mesmo antes do nascimento. Aprofundaremos estas ideias no próximo capítulo.

Fala-se, ainda, como qualidade dos valores a sua objetividade e absoluteza. Segundo tais características, eles necessitam de algo em que se apoiar, e uma ou mais consciências às quais o valor se refira ${ }^{168}$.

Finalmente, citam-se a realizabilidade e a inexauribilidade. A primeira qualidade diz respeito ao fato de os valores nunca chegarem a um termo de acabamento histórico, sendo, ao contrário, inseridos num processo de continua superação. Admitir que eles se realizassem integralmente, ensina Reale, seria transformá-los em dados. Quanto à segunda, tem-se que os valores não se esgotam, o que se liga justamente à superação constante e realizabilidade perene ${ }^{169}$.

\footnotetext{
${ }^{167}$ REALE, Miguel. Filosofia do Direito. São Paulo: Saraiva, 1982, pp. 191 e 211. Para o autor, "o homem não é uma simples entidade psicofísica ou biológica, redutível a um conjunto de fatos explicáveis pela Psicologia, pela Física, pela Anatomia, pela Biologia. No homem existe algo que representa uma possibilidade de inovação e de superamento. A natureza sempre se repete, se transforma e nada se cria. Mas o homem representa algo que é um acréscimo à natureza, a sua capacidade de síntese, tanto no ato instaurador de novos objetos do conhecimento, como no ato constitutivo de novas formas de vida. $\mathrm{O}$ que denominamos poder nomotético do espírito consiste em sua faculdade de outorgar sentido aos atos e às coisas, faculdade essa de natureza simbolizante, a começar pela instauração radical da linguagem".

${ }^{168}$ Ibid., p. 192.

${ }^{169}$ Ibid., p. 207.
} 
Toda organização sistemática que os pensadores reservam à enumeração das qualidades dos valores revela a importância desse objeto de análise, e as implicações em outras áreas do conhecimento, como o Direito.

Realizada uma breve reflexão acerca da relação entre valores e a necessidade de decisão que envolve os dilemas bioéticos, e traçadas algumas características dos valores, insta analisar a terminologia comumente utilizada nos debates: moral, ética, eticidade e moralidade.

Retornaremos às ponderações sobre a teoria dos valores por ocasião das discussões pontuadas acerca do relativismo e universalismo ético. Isto porque podemos conjecturar, em algumas teorias sobre os valores, precedentes importantes para sua compreensão ora de modo estritamente subjetivo, como as teorias psicológicas, ora em um sentido mais universalizante, como nas teorias objetivas e sociológicas.

\subsection{Moral, Ética, moralidade e eticidade}

Em qualquer debate bioético, alguns termos são recorrentes. Fala-se em conduta ética, moral, moralidade, eticidade.

Na própria composição da palavra bioética (bio, ética), insere-se um destes termos, e não outro, causando estranhamento a invenção de neologismo tal como "biomoral". Mas ao tratar de bioética, inegável que questões sobre uma ordem moral de regras, princípios morais e moralidade da conduta humana são temáticas obrigatórias e recorrentes.

Fala-se também em ética profissional, como as referências à ética médica. Por outro lado, refere-se à moralidade como princípio que deve reger a Administração Pública, sem deixar-se de fazer alusão a condutas éticas do administrador; assim também em moralismo, para referir-se ao desvirtuamento ou exacerbamento de certos ideais, ou uso caracteristicamente pejorativo, em desacordo com outros padrões - não necessariamente dominantes -, como se verifica com a utilização dos termos "moralismo religioso", ou "ser moralista".

A terminologia, às vezes, é usada de modo que a sinonímia é possível. N'outras vezes, os autores fazem questão de separar os termos, por entenderem que se tratam de coisas distintas, a começar pela própria origem de cada uma destas palavras, sua etimologia.

De início, necessário destacar que autores há que não vislumbram diferença entre os termos "ética" e "moralidade". É o caso de Peter Singer, que inicia seu livro Ética 
Prática destacando que utilizará os termos de modo indiferente ${ }^{170}$. Quanto ao autor citado, é mister destacar que a utilização dos termos como equivalentes não gera qualquer impropriedade em sua obra, pois explica e delimita o que considera ética - por conseguinte, a moralidade estaria aí englobada.

Essa postura metodológica tem a vantagem de facilitar os termos do debate, simplificando através da sinonímia. Por certo, entre leigos e acadêmicos, a utilização indistinta dos vocábulos pode dar tônica às questões que estão sendo debatidas, com importância secundária às possíveis distinções entre um e outro.

Mas se o enfoque utilizado tem o condão de sobrelevar os aspectos do problema, não deixa de ser interessante alertar quanto às possíveis diferenças que possam existir entre Moral e Ética, mesmo que, na obra, uma seja referida pela outra.

Para outros autores, a Ética englobaria a Moral e o Direito. Assim, seria termo genérico e continente dos outros dois. Por seu turno, o problema ético estaria relacionado ao "problema do valor do homem como ser que age, ou melhor, como o único ser que se conduz" $" 171$

Consideramos intricadas as relações entre Direito e Moral, o que se depreende dos debates encetados por filósofos e juristas, que chegaram a considerar um verdadeiro Cabo das Tormentas, ou Cabo dos Náufragos ${ }^{172}$. Neste ponto, faz-se necessário reservar tópico específico aos contornos dessa relação, que merece um estudo com mais vagar.

Há quem vislumbre a distinção entre Ética e Moral tomando como critério, pois, a abrangência do termo, sendo a primeira de caráter mais restrito e específico, concernente a um grupo particular de pessoas, enquanto a Moral teria um caráter mais geral, refletindo a cultura e as concepções assentadas em determinada nação ${ }^{173}$. Ambas teriam, no entanto, um caráter normativo.

Marco Segre e Claudio Cohen preferem definir Moral e Ética de outro modo. Para os autores, a moralidade constituiria um sistema de valores resultando em normas tidas

${ }^{170}$ SINGER, Peter. Ética prática. São Paulo: Martins Fontes, 2002, p. 9.

${ }^{171}$ REALE, Miguel. Filosofia do Direito. São Paulo: Saraiva, 1982, pp. 35-37. Miguel Reale discorda, em parte, de Del Vecchio, autor que propõe esta separação. Escreve: "Não concordamos com aqueles autores que, como Del Vecchio, bifurcam a Ética em dois ramos - a Moral e o Direito -, mas não discordamos deles quanto à visão da experiência jurídica como um momento da vida ética. O Direito, como experiência humana, situa-se no plano da Ética, referindo-se a toda a problemática da conduta humana subordinada a normas de caráter obrigatório".

${ }^{172}$ Ibid., p. 617.

${ }^{173}$ COHEN, Cláudio; SEGRE, Marco. Definição de valores, moral eticidade e ética. In: COHEN, Cláudio (org). Bioética. São Paulo: Edusp, 1999, p. 17. Os autores citam as lições de Barton e Barton para dizer que em termos substanciais, não haveria diferença entre Ética e Moral, somente cabendo falar-se na diferenciação quanto à amplitude das normas. 
como corretas por determinada sociedade. A Moral teria as seguintes características: a) os valores não são questionados; b) os valores são impostos; c) a desobediência enseja a aplicação de um castigo. A Ética, por seu turno, estaria relacionada à capacidade de percepção dos conflitos na vida psíquica, que engloba a razão e a emoção, fundamentandose em três pré-requisitos: a) percepção de conflitos (consciência), b) autonomia e c) coerência. A eticidade é definida como a aptidão para exercer a função ética. Concluem, quanto à diferença entre uma e outra que "enquanto que para que a moral funcione ela deve ser imposta, a ética, para ser atuante, deve ser apreendida pelo indivíduo, vinda de seu interior. A moral é imposta, a ética é percebida" ${ }^{174}$.

Do exposto, é possível concluir que, segundo essa diferenciação, a Ética apresenta um caráter autônomo, pois relacionada à capacidade individual de perceber os conflitos, enquanto a Moral, por se tratar de conjunto de normas impostas, possui caráter heterônomo. Ademais, há de ser recordado o imperativo categórico kantiano, comumente tomado como um modelo de autolegislação.

Ainda utilizando termos da teoria psicanalítica, os autores aduzem, sob uma perspectiva muito interessante, que a Moral consubstanciaria uma função do Superego e a Ética uma função do Ego $(\text { Self })^{175}$.

Em outro artigo escrito em coautoria com Flávio Carvalho Ferraz, Claudio Cohen retoma a importância da Psicanálise para os estudos da Ética, aduzindo que

\begin{abstract}
a contribuição da psicanálise para o campo da ética transcende, de muito, a constituição de uma estrita ética da psicanálise, pois ela amplia o campo da percepção do ser humano. As questões levantadas pela teoria psicanalítica acerca dos juízos de valores de bem e de mal questionam algumas vigas do edifício filosófico da ética. Por outro lado, fornecem a este edifício outras possibilidades de sustentação $^{176}$.
\end{abstract}

As abordagens interdisciplinares, como se vê, permitem uma ampliação do horizonte do conhecimento, pois, de modo dialógico, são capazes de revelar as facetas de

\footnotetext{
${ }^{174}$ Ibid., pp. 17-19.

175 Ibid., p. 19. Escrevem: "consideramos os problemas éticos como conflitos que devem ser vivenciados pessoalmente, dependendo da estrutura do indivíduo, arrastando consigo conceitos e ideais sociais introjetados e elaborados ao longo da vida".

176 COHEN, Claudio; FERRAZ, Flávio Carvalho. Direitos humanos ou ética das relações. In; COHEN, Cláudio (org). Bioética. São Paulo: Edusp, 1999, p. 39.
} 
um objeto que não podem ser apartadas e compartimentalizadas de outros aspectos que lhe dizem respeito.

Para outros autores, como Tom L. Beauchamp e James F. Childress, a Ética seria um termo genérico relacionado aos vários modos de entender e examinar a vida moral, podendo ser apreendida de dois modos: ética normativa e não normativa.

A denominada ética normativa (normative ethics) estaria relacionada à ética normativa geral (general normative ethics), preocupada com a perquirição das normas morais que devemos aceitar, buscando o motivo, a justificativa de seleção destas normas; e também, à ética prática ou aplicada (practical ethics ou applied ethics), relacionada à análise de problemas práticos, questões de políticas públicas, como a alocação de recursos na área da saúde. Por seu turno, a ética não normativa poderia ser dividida em dois tipos bem amplos, quais sejam a ética descritiva (descriptive ethics) e a metaética (methaethics). A ética descritiva seria a investigação fática das condutas morais e das crenças, com a utilização, inclusive, de técnicas científicas de pesquisa, com o apoio de profissionais das diversas áreas do conhecimento, como antropólogos, sociólogos, historiadores e psicólogos, que pesquisariam, por exemplo, as normas morais em determinada prática profissional. Por fim, a metaética estaria relacionada à análise da linguagem, dos conceitos e termos utilizados, como a significação de "direito", "obrigação", "responsabilidade"; "virtude", "moralidade" etc. Em resumo, os autores distinguem a ética normativa da não normativa baseando-se no escopo de cada uma. Enquanto esta última estaria preocupada em responder o que é o caso, a primeira estaria relacionada com a problematização do que deve ser o caso ${ }^{177}$.

Para Tom L. Beauchamp e James F. Childress, moralidade estaria relacionada às normas sobre a conduta certa e a errada, que estão tão amplamente compartilhadas, que formam uma espécie de consenso social, sendo denominada pelos autores de uma verdadeira instituição social ${ }^{178}$.

177 BEAUCHAMP, Tom L.; CHILDRESS, James F. Principles of biomedical ethics. Oxford University Press: Oxford, 2001, pp. 1-2.

${ }^{178}$ Ibid., pp. 2-3. "A moralidade se refere a normas sobre as condutas humanas certas e erradas que são amplamente compartilhadas e formam um consenso social estável (embora geralmente incompleto). Moralidade, como uma instituição social, engloba muitos padrões de conduta, incluindo princípios morais, regras, direitos e virtudes" (tradução nossa). No orignial: "morality refers to norms about right and wrong human conduct that are so widely shared that they form a stable (although usually incomplete) social consensus. Morality, as a social institution, encompasses many standards of conduct, including moral principles, rules, rights, and virtues". Os autores aprofundam as ideias referentes à moralidade, dissertando sobre uma moralidade universal (universal morality) e uma moralidade particularizada de uma comunidade (community-specific morality). 
Com isso, percebe-se que há uma interconexão entre os elementos ética e moral, aprofundando as noções de ética que, para os autores, pode ser normativa ou descritiva - o que outros autores refutam, por entender que à ética competiria tão-somente a descrição das normas morais.

No que concerne à definição do conceito de pessoa, pode-se dizer que se situa no campo de uma metaética, pois há a delimitação do termo, considerando as consequências decorrentes para o discurso ético. Implica, noutras palavras, uma análise que ultrapassa as considerações legais, adentrando no campo da Filosofia do Direito.

Convém trazer à colação, também, a interessante distinção realizada por Hans Kelsen entre Ética e Moral. Conforme ensina o autor em sua Teoria Pura do Direito, a Moral consistiria num conjunto de regras, dotadas de características próprias, sendo a Ética uma descrição científica destas regras, de modo que seria equivocado confundir uma com outra.

Afirma o autor que

no uso corrente da linguagem, assim como o Direito é confundido com a ciência jurídica, a Moral é muito frequentemente confundida com a Ética, e afirma-se desta o que só quanto àquela está certo: que regula a conduta humana, que estatui deveres e direitos, isto é, que estabelece autoritariamente normas, quando ela apenas pode conhecer e descrever a norma moral posta por uma autoridade moral ou consuetudinariamente produzida ${ }^{179}$.

Para traçar um paralelo, assim como o conjunto de normas que integra o ordenamento jurídico não se confunde com a ciência do Direito, que a toma por objeto e a descreve, a Ética teria o caráter científico e descritivo do funcionamento das normas morais, que podem ser apreendidas em termos de dever-ser. A Bioética, nesse sentido, poderia ser compreendida como um conhecimento científico referente a determinado Biodireito, entendido como conjunto de normas com conteúdo específico, como outros ramos considerados didaticamente autônomos, mas integrantes de uma unidade que é o Direito.

A Bioética apresentaria, portanto, um caráter eminentemente descritivo, em contraponto ao caráter normativo do Biodireito.

${ }^{179}$ KELSEN, Hans. Teoria Pura do Direito. São Paulo: Martins Fontes, 2009, p. 67. 
Pode-se dizer, então, que a Moral estaria para o conjunto de normas jurídicas, assim como a Ética estaria para a ciência jurídica. Para o autor, tanto a Moral como o Direito, que correspondem à ordem do dever-ser, consistiriam em normas sociais.

Por fim, por eticidade e moralidade, deve-se entender a correspondência à Ética e à Moral. Como atributos de uma conduta, significariam a correspondência aos padrões éticos e morais.

Considerando os termos como definidos por Kelsen, essa correspondência há de observar os caracteres distintivos de um e outro: só a Moral, neste caso, possui caráter normativo, sendo a Ética, no máximo, estruturada por meio de proposições descritivas, com caráter científico. Por via reflexa, a eticidade de uma conduta, se não se refere às normas de uma determinada Moral, ao menos concerne à descrição de determinadas normas morais.

Porém, mesmo considerando louvável a conhecida distinção entre Ética e Moral, em termos estritamente científicos, uma se referindo à específica ordem normativa e outra a sua descrição, entendemos que, como qualificadores da conduta, os termos "ético" e "moral" podem ser utilizados como sinônimos e, para os fins desse trabalho, são usados indistintamente, sem prejuízo da cientificidade.

Ressaltamos: não se trata de ignorar as distinções entre ética e moral, seja em termos de abrangência ampla ou restrita, seja quanto à diferenciação entre ciência e norma. Mas, apenas como qualificadores da conduta, empregamos de modo equivalente ambos os termos, falando em conduta ética ou moralidade da ação.

Passemos às considerações sobre as relações entre Direito e Moral.

\subsection{Direito e Moral}

As relações entre Direito e Moral permeiam os debates entre os filósofos do Direito há muito tempo. É possível, já entre os antigos, verificar o tormentoso tema que atrai pensadores e dá azo a debates acalorados.

A dificuldade de delimitação é nítida ${ }^{180}$, primeiro porque não há acordo sobre o que representa a Moral, colhendo-se muitas definições entre os estudiosos, e segundo porque

${ }^{180}$ REALE, Miguel. Filosofia do Direito. São Paulo: Saraiva, 1982, p. 617. Lembra o jurista as dificuldades de se traçar as relações entre Direito e Moral, a ponto de, segundo Jhering, se considerar o "Cabo Horn" ou o "Cabo das Tormentas" da Filosofia do Direito, ou, de acordo com pensadores mais pessimistas, como Benedetto Crocce, um verdadeiro "Cabo dos Náufragos". 
há dúvidas acerca da possibilidade de estabelecer-se uma relação entre um e outro. Como ensina Reale,

na Hélade encontramos, entre os pré-socráticos, uma distinção fundamental, que é também um dos motivos da "Antígone" de Sófocles, cuja atualidade é um conforto para os que cultivam os valores espirituais: a distinção entre o justo por natureza e o justo por convenção, ou, por outras palavras, entre lei natural e lei positiva ${ }^{181}$.

Para que seja possível estabelecer relações, é necessário tomar um parâmetro de comparação, que aproxime ou afaste os objetos relacionados. Neste caso, tem-se que Direito e Moral constituem ordens normativas. Quer na diferenciação entre abrangência ampla, comparada com a Ética, quer com a qualidade de normas heterônomas, impostas, ou ainda na contraposição entre Moral e Ética considerando esta como de caráter estritamente científico e descritivo, pode-se dizer que na Moral o caráter normativo está presente.

Mas a pergunta que se faz é: existindo uma relação qual seriam os pontos de intersecção e afastamento entre ambas as esferas normativas? Poderiam ser englobadas numa relação de continente e conteúdo, de modo que uma abrangeria a outra? Se essa abordagem for possível, qual a ordem mais ampla, que contém a outra? Ainda nesse caso, o que ficaria fora de uma e ainda pertenceria à outra?

É comum encontrar nos livros que tratam do assunto inclusive esquemas gráficogeométricos que representariam, de modo didático, as possíveis relações existentes entre Direito e Moral, comumente utilizando-se a imagem mental de circunferências, ora concêntricas, ora tangentes e secantes, o que reflete a opinião de determinado autor sobre a relação estabelecida entre as duas ordens.

Se houver distinção, mínima que seja, entre Direito e Moral, faz-se necessário descrever os pontos de convergência e de separação, o que significa a necessidade de especificar as características de cada um.

Afinal, haveria uma diferença de conteúdo entre o Direito e a Moral? Podemos dizer que o Direito contém um mínimo ético, representado pela Moral? Se apresentam uma

${ }^{181}$ Ibid., p. 618. Como ensina o autor, no início deste capítulo sobre as relações entre o Direito e a Moral, "o acerto está em saber distinguir, não em separar. Em tais domínios o homem afoito, quando se depara com uma diferença, julga-se logo autorizado a proclamar uma separação, enquanto, na realidade, deveremos compreender que certos fenômenos se distinguem, mas não se separam”. 
e outra ordem o caráter normativo, há uma sanção institucionalizada? Qual a característica das sanções eventualmente presentes no Direito e na Moral? Podemos considerar a Moral como equivalente à lei natural, ou seja, um direito natural, em contraposição ao direito positivo?

Nesse caso, interessa apontar que, hodiernamente, vê-se a positivação de preceitos até então considerados de ordem eminentemente moral, ou mesmo edição de diplomas normativos em que o princípio da moralidade está assentado como lei, ao lado do princípio da legalidade, como se o Direito contivesse a ideia de moralidade. O ordenamento jurídico dispõe também de regras que possibilitam provas que não ofendam a moral e bons costumes, acentuando-se a ideia de inter-relação entre um dever de moralidade ou honestidade e licitude.

Preceitua-se, ademais, um dever de probidade, ou mesmo que as partes se portem com boa-fé e lealdade, numa postura colaborativa mútua. Por outro lado, pune-se a má-fé de litigantes, a improbidade de administradores.

Assim, nota-se uma constante referência entre os dois termos, o que corrobora a ideia de uma relação intrínseca a existir entre Direito e Moral.

Com isso, outra pergunta exsurge: o Direito é, ou deve ser moral? Com a ideia de Moral, quer-se referir à ideia de justiça? Um direito injusto seria ainda Direito? Se a ideia de justiça insere-se na definição do Direito, como identificar o conteúdo do que se considera justo? Nesse caso, estaríamos em direção de uma moral absoluta? Vale pensar também se as normas positivadas por determinado Estado refletiriam, pelo consenso que a lei possa simbolizar, a preferência de determinados valores ou preceitos morais. Eis algumas das dificuldades que rondam os debates concernentes à relação entre Direito e Moral.

Para melhor compreensão, impende realizar uma breve incursão histórica sobre os delineamentos traçados por filósofos e pensadores sobre as relações entre estas ordens, Direito e Moral.

Ademais, entender como se pontuaram as conexões entre um e outro servirá para a melhor compreensão dos argumentos que se põem nas discussões entre relativismo e universalimo. Há entre alguns autores que propugnam o viés universalista um apelo a preceitos inatos e fundantes, que não poderiam ser escamoteados por uma ordem positiva. 


\subsubsection{Breve panorama histórico}

Numa análise inicial, que se propõe a elaborar um escorço histórico sobre o delineamento e relações entre o Direito e a Moral, é interessante trazer, preambularmente, os ensinamentos mitológicos ${ }^{182}$, que abrangem uma vastidão de significados e podem esclarecer a compreensão ética nos povos antigos e mesmo muitas das concepções presentes no mundo atual. Além do mais, ao contrário do que se poderia supor, não existe uma incompatibilidade ou contraposição radical entre mito de um lado e a ciência e a Filosofia de outro. Trata-se, em verdade, de um preconceito ${ }^{183}$.

De início, é preciso salientar ao menos dois momentos visivelmente diferenciados nas relações estabelecidas entre os homens e os deuses gregos. De um lado, há a convivência entre eles em áreas de terra. Os deuses não estão só no Olimpos; na planície de Mecona, em Corinto, deuses e homens convivem em harmonia. No destaque de JeanPierre Vernant, na

idade de ouro, quando os deuses e os homens ainda não estavam separados, idade de ouro que às vezes também se chama o tempo de Crono, esse tempo é anterior à luta que se desata entre Crono, com os Titãs, e Zeus, com os Olímpios, quando o mundo divino ainda não está entregue à violência brutal ${ }^{184}$.

Na mitologia greco-romana, destaca Luigi Zoja, os deuses eram pessoas em tudo similares aos homens ${ }^{185}$.

Nesta época, a idade de ouro, os homens não conheciam nem nascimento nem morte, e a terra lhes fornecia todo o sustento sem a necessidade da labuta. Permaneciam sempre jovens, "misturados com os deuses, iguais aos deuses"186. Por outro lado, em comparação com os deuses, os homens são fracos, não dispõem de força bastante. Para acabar com a competição entre os dois grupos, Zeus lança mão de Prometeu.

182 ZOJA, Luigi. História da arrogância: Psicologia e limites do desenvolvimento humano. São Paulo: Axis Mundi, 2000, p. 4. No sentido original, "mito", derivado de Mýthos, não tinha conotação de história irreal, mas sim de narrativa majestosa e transcendente. "O homem necessitava da narrativa para identificar-se com figuras humanas".

183 Ibid., p.9.

${ }^{184}$ VERNANT, Jean Pierre. O universo, os deuses, os homens. São Paulo: Companhia das Letras, 2000, p. 56.

${ }^{185}$ ZOJA, Luigi. História da arrogância: Psicologia e limites do desenvolvimento humano. São Paulo: Axis Mundi, 2000, p.13.

${ }^{186}$ VERNANT, Jean Pierre. O universo, os deuses, os homens. São Paulo: Companhia das Letras, 2000, p. 57 
O Titã não é nem um deus nem um Olímpio, e apresenta uma condição de certo modo paradoxal.

\begin{abstract}
Seu estatuto se aproxima das criaturas humanas, pois estas são também ambíguas, têm um aspecto de divindade - no início, dividiam sua vida com os deuses - e ao mesmo tempo um aspecto de animalidade, de bestialidade. Assim sendo, também há entre os homens, como em Prometeu, aspectos contraditórios $^{187}$.
\end{abstract}

Além do mais, "Prometeu possui um espírito de rebelião, esperto e indisciplinado, está sempre pronto para criticar" $" 188$.

A divisão do estatuto entre deuses e homens então ocorre e se dá pelo episódio da repartição de um bovídeo, divisão esta a cargo do Titã Prometeu. Desta forma, no intento de ludibriar os deuses, Prometeu preenche o bucho pouco apetitoso com tudo o que há de melhor do animal e, de outro lado, o sebo, que pelo aspecto externo é o melhor, é preenchido por ossos. Os deuses escolhem este último e, deste modo, Prometeu consegue enganá-los pelas aparências ${ }^{189}$. Porém, "de agora em diante, os humanos são mortais, os efêmeros, contrariamente aos deuses, que são os não mortais" ${ }^{190}$. E Zeus se vinga, escondendo o fogo.

Nesse contexto, vale a utilização do termo brotos, relacionado ao homem enquanto ser mortal, e a posição vertical face aos deuses, ou seja, “a condição de aflição que caracteriza o homem nas mãos dos deuses"191.

$\mathrm{Na}$ Grécia arcaica, não havia um princípio ético claro ao qual se ancoravam os deuses. Além disso, o deus deveria conter tudo o que não pudesse ser hospedado na alma do homem, sendo excluído da comunidade aquele que não controlasse as emoções. Por

\footnotetext{
${ }^{187}$ Ibid., p. 61

188 Ibid., 2000, p. 60; ZOJA, Luigi. História da arrogância: Psicologia e limites do desenvolvimento humano. São Paulo: Axis Mundi, 2000, p. 134. Diz Zoja: "Prometeu tem uma missão impessoal, abstrata e absoluta: ajudar o homem, entendido quase no sentido cristão de 'o próximo'. Mas, numa época de divindades ciumentas e desprovidas de providência, essa meta é prematuramente humanista e, portanto, discordante da moral em vigor".

${ }^{189}$ Ou teriam se deixado enganar por Prometeu?

${ }^{190}$ VERNANT, Jean Pierre. O universo, os deuses, os homens. São Paulo: Companhia das Letras, 2000, p. 62-64.

${ }^{191}$ LORAUX, Nicole. A tragédia grega e o humano. In: NOVAES, Adauto (org.). Ética: vários autores. São Paulo: Companhia das Letras, 2007, pp.26-27.
} 
conta disso, afirma Luigi Zoja que "a relação fundamental entre o homem e o deus não é de liturgia, mas invasão" ${ }^{\prime 192}$.

Daí falar-se em um deus emocional do politeísmo, ao contrário do deus monoteísta, que oferecia ao homem um absoluto e um centro ${ }^{193}$.

Os gregos personificavam suas emoções com um claro objetivo que se pode intuir. Figurá-las como deuses era funcional à necessidade de distanciar-se destes e, ao mesmo tempo, ao temor reverencial pela ética que estava sendo construída. Uma vez que se plasmavam deuses para libertar-se das emoções intoleráveis, a teologia e a ética religiosa que se seguiram tiveram o objetivo de manter o deus ainda mais distante. Preso num círculo vicioso, o politeísmo tomava uma meta oposta àquela adotada pelo cristianismo. Na religião dos gregos, não virá instituído nada semelhante ao esforço cristão de seguir o exemplo divino (imitatio Christi), mas, como observou Nietzsche, uma espécie de seu contrário: do homem justo esperava-se que não repoduzisse as qualidades dos deuses. O pecado mais grave, na verdade, era a hýbris, a transgressão do limite imposto à condição de todos, o ultraje (em italiano oltraggio, palavra que vem de "oltre", como hýbris vem talvez de seu correspondente grego hypér), a arrogância (de adrogare, pedir, pretender para si) de quem é excelente em uma qualidade, subtraindo-a assim do deus que a representa ${ }^{194}$.

Releva destacar, neste ínterim, a noção de hybris grega, que de certo modo pode ser ligada à noção de ética, considerando o relacionamento entre os deuses e os homens. Leciona Lídia Reis de Almeida Prado que o termo pode ser entendido como "tudo aquilo que ultrapassa a medida (démesure), excesso, descomedimento, sendo considerada por Hesíodo a maior inimiga da Justiça (Diké)"195.

${ }^{192}$ ZOJA, Luigi. História da arrogância: Psicologia e limites do desenvolvimento humano. São Paulo: Axis Mundi, 2000, pp. 33-34. Destaca o autor que "quando um deus intervinha no homem, este regredia a estados de espírito que poderíamos chamar de primários, seja no sentido de que é possível encontrá-los já na criança, seja no sentido de que se apresentam com uma modalidade a tal ponto totalizadora e complexa que não se permite decompô-los em suas partes constituintes".

${ }^{193}$ Ibid., p. 36.

${ }^{194}$ Ibid., pp.36-44. O autor apresenta, com detalhes, a evolução do relacionamento entre homens e deuses. Narra que "os deuses não seguem o próprio capricho, e sim um critério estável: invejam os homens que conseguem ser felizes e, por isso, os castigam. Afirma-se o phthónos theôn". Diz adiante: "Ao declínio dos deuses emocionais, competitivos entre si, corresponde agora a afirmação da única justiça divina invejosa. A moral evolui, convergindo para uma forma unificada que facilitará, em seguida, a afirmação do monoteísmo".

${ }^{195}$ PRADO, Lidia Reis de Almeida. O juiz e a emoção: aspectos da lógica da decisão judicial. Campinas: Millenium, 2008, pp.80 e 207. Destaca a autora, citando Erich Neumann, que a hybris poderia ser relacionada à ímpia soberba, a inflação que conduz à ruína, quando os homens se consideram como os deuses. 
Destaca Werner Jaeger, a propósito, que

\begin{abstract}
a idéia de hybris, originariamente concebida de modo perfeitamente concreto na sua oposição à diké, e limitada à esfera terrena do direito, cedo se estende à esfera religiosa. Compreende agora a pleonexia do Homem em face da divindade. É este novo conceito da hybris que, no tempo dos tiranos, se torna a expressão clássica do sentimento religioso. Foi este o significado com que a palavra passou ao nosso vocabulário. Unida à idéia da inveja dos deuses, esta concepção determinou por longo tempo, do modo mais vigoroso, as representações essenciais das mais vastas esferas da religião grega. A felicidade dos mortais é mutável como os dias. O Homem não deve, portanto, aspirar ao que está alto demais ${ }^{196}$.
\end{abstract}

Porém, algo interessante se passa acerca da moral dos homens e deuses. Pelo menos na Grécia antiga, no período arcaico, o homem é "mais moral" que sua divindade. "Se némesis é justiça divina, aidós é a justiça da sociedade.".197

Enfim, na síntese de Zoja, a ética ocidental poderia ser dividida em basicamente três etapas, daí chegando até nossos dias. Descreve a a) ética mítica, em que "a ação humana é limitada pela fixidez do mito e, no mundo grego, pelo phthónos que reserva o sucesso ao deus, impedindo o homem de concebê-lo como seu", o que seria uma ética aristocrática; b) ética axial e hýbris da consciência, em que a "ação humana é guiada por uma necessidade de expansão que ajuda a remover os tabus", configurando uma ética democrática; e, finalmente, c) a ética do reaparecimento do limite, como se os deuses antigos reaparecessem como um todo invejoso ${ }^{198}$.

Passemos, agora, às relações entre Direito e Moral que se estabeleceram em outros povos, num período posterior ao cenário mítico.

Como relatado pouco acima, as primeiras ideias que podem ser tomadas nas relações entre o Direito e a Moral dizem respeito à separação entre o que se considerava justo por natureza e justo por convenção. Não havia, entretanto - e esta é uma questão

\footnotetext{
${ }^{196}$ JAEGER, Werner. Paideia: a formação do homem grego. São Paulo: Martins Fontes, 2010, pp. $210-211$. ${ }^{197}$ ZOJA, Luigi. História da arrogância: Psicologia e limites do desenvolvimento humano. São Paulo: Axis Mundi, 2000, pp 47-49. Némesis passaria a indicar tudo quanto se opõe ao excesso (hýbris). Aidós, por seu turno, indica a vergonha que se sente perante um par quando se comete uma injustiça.

${ }^{198}$ Ibid., pp. 177-181. "A resposta negativa e o encontro com um limite ciumento são hoje mais claros que no passado, porque ocupam dois planos diferentes, mas em acordo significativo: o da resposta externa, social e ambiental, que se subtrai à satisfação buscada; e, mais obscuro, embora não menos violento, o plano de um não que provém de um ângulo escuro de nossa psiquê. Este é conceitualizado pela filosofia da existência como angústia do existir: exsistere, consciência dolorosa de relatividade, separação e limitação diante da universalidade do ser. Eu sou quase nada: como posso querer tudo?"
} 
polêmica - uma separação nítida entre o que fosse jurídico e não jurídico, ou entre o Direito e a Ética, propriamente. No caso, o Direito apareceria numa explicação contratualista, como uma "convenção feita entre os homens cansados de agressões mútuas, exaustos do estado selvagem, cheio de perigos recíprocos, de insegurança para todos" ${ }^{\text {"199 }}$.

Entre os romanos, a conclusão a que se pode chegar é que também eles não lograram êxito na delimitação precisa da distinção existente entre os dois campos, verificando-se, ao contrário, uma verdadeira confusão e identificação entre Direito e Moral, que se vê em alguns textos que chegaram aos nossos dias.

Ensina Miguel Reale que os romanos, de certo modo responsáveis pela fundação de uma ciência do Direito autônoma, abrindo caminho para uma compreensão profissional do Direito, repetiram a fórmula grega de distinção entre o justo por natureza e o justo por convenção, como uma diferenciação entre Direito Positivo e Direito Natural. Encontram-se entre os romanos, porém, interpretações, adágios e preceitos que, aparentemente, conduziriam à ideia de que tiveram noção das diferenças entre Direito e Moral, como a formulação extraída de Paulo, segundo a qual nem tudo o que é lícito é honesto (non omne quod licet honestum est), separando, pois, o lícito moral do lícito jurídico. Entretanto, não são encontrados os critérios diferenciadores entre uma ordem e outra, daí a se dizer também que os jurisconsultos romanos tiveram consciência do problema, porém não tiveram ciência deste $\mathrm{e}^{200}$.

Mas não é só. Em algumas definições de Direito, verifica-se a confusão entre o jurídico e o moral. É o caso da definição de Celso, que toma o Direito como a "arte do bom e do eqüitativo" (ars boni et aequi), cuja interpretação pode conduzir a uma miscelânea entre Moral e Direito. E se este último é a ciência ou arte do bom e do equitativo, afirmam os estudiosos, não resta dúvida que não existe nem mesmo consciência de um problema. Corrobora essa assertiva o fato de serem apresentados como preceitos fundamentais do Direito - os Juris Praecepta - "viver honestamente" (honeste vivere), "não prejudicar a outrem" (alterum non laedere) e "dar a cada um aquilo que é seu" (suum cuique tribuere) 201.

${ }^{199}$ REALE, Miguel. Filosofia do Direito. São Paulo: Saraiva, 1982, pp. 618-619. Aristóteles reconhece que "existe o justo por lei e o justo por natureza, afirmando que este tem por toda a parte a mesma força, por não depender das opiniões e dos decretos dos homens, expressão que é da natureza racional do homem".

${ }^{200}$ Ibid., pp. 623-626.

${ }^{201}$ Ibid., 1982, p. 627. 
É curioso notar que, mesmo hoje, é comum mencionarem nas disciplinas de Teoria Geral do Direito que estes são princípios gerais do Direito, que informam sua interpretação e todo o seu ordenamento.

Vale destacar que os romanos desenvolveram uma forma de pensamento denominada jurisprudencial, que deu azo a um saber de natureza eminentemente prático, o que justifica a construção de conceitos muitas vezes dicotômicos ${ }^{202}$. Poderíamos aventar se, dado o interesse prático, talvez não tivesse se estabelecido uma separação acurada, mais abstrata, entre Direito e Moral. Assim, "faltou aos romanos, pela natureza de sua formação jurídica, o senso filosófico da questão ora ventilada, como escapara aos gregos, a estes pelo fato de não terem chegado a elaborar um mundo jurídico com configuração autônoma" ${ }^{203}$.

Durante a Idade Média, pode-se dizer que não existe, também, uma distinção nítida entre as duas esferas normativas, de maneira que o Direito e a Moral acabam por se identificar. Costumam ser citados alguns expoentes do pensamento medieval, como Santo Agostinho e São Tomás de Aquino.

Este, especificamente, tratou da ideia de uma lex aeterna, que, para além de ter um valor universal, poderia ser considerada um preceito de ordem cósmica, e que não se confunde com o que o filósofo denomina de lex divina, verdadeira revelação de Deus, e nem com a lex humana. A lex naturalis aparece como uma derivação de lex aeterna, por meio da razão humana. Nota-se, portanto, a importância da razão na teoria tomista. Porém, como se disse, o Direito e a Moral acabavam por se identificar na Idade Média. A influência do Cristianismo pode ser notada e, como lembra Reale,

em tal quadro ideológico, seria de certa maneira impossível uma distinção entre o mundo moral e o mundo jurídico: - todos os problemas são postos em uma unidade que não se pode partir, a risco de atingir-se o cerne do pensamento tomista. É uma concepção teocêntrica do Direito, porque fundada numa concepção teocêntrica do universo e da vida. Tem sido observado por vários autores que, no tomismo, como em geral no pensamento medieval, opera-se uma inversão com referência ao mundo antigo: - se neste o Direito se subordina à Moral, naquele é a Moral que, de certo modo, se legaliza, assumindo as características extrínsecas do Direito, a força nomológica da juridicidade ${ }^{204}$.

${ }^{202}$ FERRAZ Jr. Tércio Sampaio. Introdução ao estudo do Direito: técnica, decisão, dominação. São Paulo: Atlas, 1994, p. 59.

${ }^{203}$ REALE, Miguel. Filosofia do Direito. São Paulo: Saraiva, 1982, pp. 629-630.

${ }^{204}$ Ibid., pp. 632-639. 
Na lição de Tércio Sampaio Ferraz Jr., o Direito adquire uma dimensão de sacralidade transcendental ${ }^{205}$. Assim, Direito e Moral se confundem porque se identificam, pois só pode ser Direito o que, em última instância, estiver em conformidade com a lex aeterna ou coincidir com o Direito Natural. De outro modo, um direito em desacordo com os preceitos da lex naturalis não pode ser Direito.

De certa maneira, a ideia de um direito que só pode ser válido se compatível com princípios fundamentais, inscritos e apreendidos através da razão, decorrentes de uma lei natural, ou de uma lei revelada por uma entidade cósmica ou divina, pode embasar um pensamento moral universalista.

A própria concepção de que todos os homens nascem iguais em direito e obrigações, ou que devem ser respeitados por uma dignidade intrínseca, nada mais revela do que uma matriz jusnaturalista, que inegavelmente persiste em inúmeros diplomas internacionais relacionados aos direitos humanos.

Convém tratar nesse momento de como se apresentou o problema apontado, ou seja, a existência ou não de uma diferenciação entre o Direito e a Moral, na Era Moderna. Pode-se dizer que, nesse período, a distinção entre as duas ordens normativas ganha contornos mais precisos.

Com o Renascimento, tudo passa a ser explicado em termos estritamente humanos. Como destacado por Reale, essa questão "não recebe do alto qualquer explicação, porque sujeita tudo a uma verificação de ordem racional, dando valor essencial ao problema das origens do conhecimento, a uma fundamentação segundo verdades evidentes"206 .

Funda-se, na Época Moderna, a chamada Escola do Direito Natural, vertente jusnaturalista diferente da ideia de Direito Natural tomista até então existente. Já não há uma vinculação estrita aos ditames de uma lei eterna, ganhando corpo os escritos de pensadores contratualistas que tentaram explicar, cada um com as suas nuances, o surgimento do Estado e da sociedade. Como exemplo, há as obras de Hobbes e de Rousseau, que conformam espécies de contratualismos ligeiramente diversas entre si. É correto dizer que "aqui já começa a se firmar uma distinção entre o Direito (fundado em um contrato social) e a Moral, anterior ao contrato positivo e, de certo modo, sua condição primordial" 207.

${ }^{205}$ FERRAZ Jr. Tércio Sampaio. Introdução ao estudo do Direito: técnica, decisão, dominação. São Paulo: Atlas, 1994, p. 63.

${ }^{206}$ REALE, Miguel. Filosofia do Direito. São Paulo: Saraiva, 1982, p. 641.

${ }^{207}$ Ibid., pp. 643-644. 
É como se a Moral correspondesse ao que restava assente antes da conformação do pacto social, responsável pelo Direito. Podemos aventar que esta diferenciação assemelhase, ainda que em alguns aspectos, à célebre distinção entre o justo por natureza e o justo por convenção. Não é por outra razão que, para Grócio, autor que se destaca entre os jusnaturalistas,

o Direito Natural - que é uma expressão da Moral, segundo ensinamentos tradicionais, por ele ainda acolhidos -, não possui fundamento contratual, mas o Direito Positivo, este sim é a expressão de um contrato. Neste caso, o "contrato" vale como categoria distintiva entre o mundo moral, equiparado ao Direito Natural, e o mundo jurídico, só este resultante de convenção. Em suma, enquanto a Moral é natural, o Direito é convencional ${ }^{208}$.

Hoje, inúmeros pensadores traçam parâmetros distintivos entre Direito e Moral. Convém destacar alguns dos apontamentos realizados pelos autores que abordam as relações - se existentes - entre essas ordens normativas. É o que faremos no item que se segue.

\subsubsection{Relações entre o Direito e a Moral}

Verificado o panorama histórico das relações entre e o Direito e a Moral, convém destacar como o problema é enfrentado por alguns estudiosos da Filosofia e da Teoria Geral do Direito.

A questão das relações entre o Direito e a Moral pode ter interpretações várias, como se verificou nas indagações iniciais, podendo ser consideradas as conexões que existem e aquelas que devem (ou não) existir.

É inegável que a moral social possa influenciar o direito posto. Porém, daí a afirmar que este deve corresponder àquela não é conclusão necessária.

Deveras, neste aspecto Hart destaca que

não pode seriamente discutir-se que o desenvolvimento do direito, em todos os tempos e lugares, tem de facto sido profundamente influenciado, quer pela moral convencional, quer por ideais de grupos sociais particulares, quer ainda por formas de crítica moral estabelecida sustentadas por indivíduos cujo

${ }^{208}$ Ibid., p. 644. 
horizonte moral transcendeu a moral corretamente aceite. Mas é possível tomar essa verdade de forma ilícita, como uma justificação para uma diferente proposição: a saber, que um sistema jurídico deve mostrar alguma conformidade específica com a moral ou justiça, ou deve repousar sobre uma convicção amplamente difundida de que há uma obrigação moral de lhe obedecer ${ }^{209}$.

Pode haver uma correspondência de regras, como determinada sociedade que positiva juridicamente o dever de não matar os semelhantes, preceito que já estava inserido na ordenação do considerado moralmente devido, ou seja, o respeito à vida dos outros membros da comunidade.

Mas a relação, apesar de possível, é não necessária; uma ordem não repete a outra. Se assim fosse, nenhuma distinção haveria entre ambas, pelo que todo sentimento social acabaria inserido no ordenamento jurídico, como uma regra posta. Daí uma questão que muitos pensadores colocam em suas obras: o direito deve ser justo, ou o direito injusto é ainda direito?

Hart se põe a pensar em inúmeras relações que possam existir entre o Direito e a Moral, o que, de plano, acentua a complexidade da questão - ou questões - advinda(s) do estudo, que não tem a pretensão de ser esgotado neste trabalho.

Uma primeira relação pode ser pensada em termos de Direito e poder, na medida em que ora as normas postas podem ser acatadas pela convicção de que devem ser aceitas, por serem moralmente vinculativas, ora, ao contrário, regras são meramente impostas pela força. Tem-se, em foco, uma das questões que deita raízes nas discussões acerca da própria legitimidade das regras sociais, ou, numa indagação, "por que devo obedecer?". A obediência à norma pode provir de inúmeras razões e interesses. Não há uma relação entre algo não poder ser reconhecido como juridicamente obrigatório a não ser que seja aceito como moralmente obrigatório ${ }^{210}$.

Outra forma de relação analisada pelo autor diz respeito a uma maneira mais incisiva, em que a Moral é incorporada pelo Direito através da legislação. Assim,

as leis podem ser uma mera carapaça jurídica e exigir pelos seus termos expressos que sejam preenchidos com recurso a princípios morais; o elenco de contratos tutelados juridicamente pode ser limitado por referência a concepções

\footnotetext{
${ }^{209}$ HART, Herbert L. A. O conceito de Direito. Lisboa: Fundação Lacouste Gulbenkian, 2007, p. 201.

${ }^{210}$ Ibid., p. 219.
} 
de moral e de equidade; a responsabilidade pelos ilícitos cíveis e criminais pode ser ajustada aos pontos de vista prevalecentes de responsabilidade moral $^{211}$.

Podemos pensar tal sistema jurídico como uma reprodução especular das regras morais e, nesse sentido, só é jurídico o que é justo, por se conformar às regras moralmente aceitas. Uma concepção tal, na verdade, confunde as duas esferas normativas, de maneira que não se pode diferenciar uma da outra, prevalecendo uma comunicação que as aproxima. Porém, ressalta Hart, a "estabilidade dos sistemas jurídicos depende em parte de tais tipos de correspondência com a moral" ${ }^{212}$, o que se relaciona ao sentido de justiça a que alude Tércio Sampaio Ferraz Jr., conforme verificaremos adiante.

Também é usual encontrarmos relações veementes entre Direito e Moral no que concerne à utilização desta como mote interpretativo daquele. É comum, por exemplo, referenciar como forma de atingir uma decisão justa a necessidade de o hermeneuta buscar, nas suas decisões, respaldo na equidade, princípios gerais que espelham reclamos morais dominantes.

A letra cega da lei pode ser propulsora de injustiças, a serem afastadas pelo toque da Moral. Mas é preciso destacar que não haveria uma moral absoluta, única. Mesmo que se verifique uma dominante, há sempre uma necessidade de se optar entre valores. Ora,

uma decisão judicial, especialmente em questões de alta importância constitucional, envolve frequentemente uma escolha entre valores morais e não uma simples aplicação de um único princípio moral proeminente; será tolice acreditar que, quando o significado do direito é objecto de dúvidas, a moral tem sempre uma resposta clara a dar ${ }^{213}$.

Outra relação entre Direito e Moral encontra uma arquitetura mais intrincada, pois põe em discussão a existência de uma diversidade moral em contraponto com uma moral absoluta. Assim, no anteparo das alusões à necessidade de o Direito conformar-se com a Moral situa-se a indagação: qual moral?

Mais uma ponderação acerca das duas ordens normativas considera que

${ }^{211}$ Ibid., p. 220.

212 Ibid., p. 220.

${ }^{213}$ Ibid., pp. 220-221. 
a distinção entre um bom sistema jurídico, que se conforma em certos pontos com a moral e a justiça, e um sistema jurídico que não o faz é falaciosa, isto porque é necessariamente realizado um mínimo de justiça sempre que o comportamento humano é controlado por regras gerais anunciadas publicamente e aplicadas por via judicial ${ }^{214}$.

Por fim, Hart analisa as relações entre validade jurídica e o conteúdo do Direito. A questão que se põe é se este pode ter qualquer conteúdo, cuja linha de defesa é armada por positivistas. Assim, discute-se se as regras moralmente iníquas podem ser ainda consideradas Direito. De um lado,

pode parecer então tentador dizer que as leis que se associaram à iniqüidade ou a permitiram não deviam ser reconhecidas como válidas, ou não deviam ter a qualificação de direito, mesmo se o sistema em que foram promulgadas não reconheciam qualquer restrição à competência legislativa do seu poder legislativo $^{215}$.

Daí surge a distinção entre um conceito amplo e um conceito restrito de Direito.

Sob a ótica de um conceito amplo, estariam abarcadas todas as regras, mesmo as iníquas. Ou seja, mesmo que contrárias a determinados preceitos morais, as regras jurídicas com conteúdo considerado inadequado, ruim ou injusto ainda assim deveriam ser consideradas regras jurídicas válidas. D’outro turno, sob um viés mais restrito do conceito de Direito, seriam afastadas as leis moralmente iníquas. Conclui o autor que um conceito de Direito que permita ditinguir entre sua invalidade e a sua imoralidade, possibilita verificar a complexidade e a variedade destas questões, enquanto que um conceito restrito de Direito, que nega a validade jurídica às regras iníquas, pode cegar-nos para elas ${ }^{216}$.

Nesse breve panorama colacionado por Hart, inúmeras questões mostram-se extremamente controversas, não se verificando, pois, acordo entre os pensadores. Algumas merecem aprofundamento neste trabalho.

Entre os vários pensadores da Filosofia do Direito que se propõem a pensar as relações existentes entre o Direito e a Moral, interessante destacar o pensamento de Hans Kelsen. Em sua Teoria Pura do Direito, após expor as diferenças entre a Ética e a Moral, aquela descritiva e esta de caráter normativo, o autor estabelece que o Direito e a Moral

\footnotetext{
${ }^{214}$ Ibid., p. 222.

215 Ibid., p. 224.

${ }^{216}$ Ibid., pp. 223-228.
} 
devem ser considerados, antes de tudo, espécies de normas sociais, refutando as tentativas de estabelecer diferenças entre essas ordens normativas com base na ideia de regulamentação da conduta interior ou com referência à produção e aplicação das normas.

Assim, conclui o autor, baseando-se na ideia de coação e de sanção, que

uma distinção entre o Direito e a Moral não pode encontrar-se naquilo que as duas ordens sociais prescrevem ou proíbem, mas no como elas prescrevem ou proíbem uma determinada conduta humana. O Direito só pode ser distinguido essencialmente da Moral (...) se concebe como uma ordem de coação, isto é, uma ordem normativa que procura obter uma determinada conduta humana ligando à conduta oposta um ato de coerção socialmente organizado, enquanto a Moral é uma ordem social que não constitui quaisquer sanções desse tipo, visto que as suas sanções apenas consistem na aprovação da conduta conforme as normas e na desaprovação da conduta contrária às normas, nela não entrando sequer em linha de conta, portanto, o emprego da força física ${ }^{217}$.

Ademais, o autor rejeita com veemência a noção de que o Direito deva ser, por essência, moral. Assim, como será destacado logo adiante, Kelsen adota uma teoria relativista, pelo fato de que se o Direito devesse ser moral, estaria, em verdade, pressupondo uma Moral Absoluta.

Tércio Sampaio Ferraz Jr., após reconhecer a complexidade de se estabelecerem relações entre Direito e Moral, discorre sobre as clássicas distinções que os estudiosos da Filosofia do Direito estabelecem entre tais áreas, como a exterioridade ou interioridade do comportamento, a instância que qualifica o julgamento e a exigência de deliberação e promulgação, passa a aprofundar algumas considerações entre o Direito e a Moral, ou, mais especificamente, o sentido que se há em falar de uma moralidade do Direito, as relações entre Direito e Justiça.

É inegável que haja diferenças e semelhanças entre as duas ordens normativas, que não necessariamente coincidem. Assim, ensina Tércio, o Direito pode ser considerado imoral: um direito que não se coaduna com princípios tidos como justos pela sociedade, pois a justiça não é um fator constitutivo do Direito. Porém, a justiça configura um

\footnotetext{
${ }^{217}$ KELSEN, Hans. Teoria Pura do Direito. São Paulo: Martins Fontes, 2009, pp.68-71.
} 
princípio regulativo, conferindo sentido ao Direito. Ou seja, "a imoralidade faz com que a obrigação jurídica perca o sentido, mas não torna a obrigação juridicamente inválida" 218 .

Com isso, assenta-se a ideia de que pode existir um direito injusto, objetivamente válido, baseado em relações hierárquicas e metacomplementares estabelecidas entre autoridade e sujeito, mas isto tornará inevitável a perda de sentido desse direito implementado. Embora válido e eficaz, será injusto, o que tem a ver, como leciona o autor, com a afetação de uma espécie de dignidade intrínseca, que se relaciona ao sentido das coisas e afeta a orientação do homem. Enfim, o direito,

como ato de poder não tem o seu sentido no próprio poder. E aí repousa, ao mesmo tempo, a força e a fragilidade da moralidade em face do direito. É possível implantar um direito à margem ou até contra a exigência moral de justiça. Aí está a fragilidade. Mas é impossível evitar-lhe a manifesta percepção da injustiça e a conseqüente perda de sentido. Aí está a força ${ }^{219}$.

A Justiça pode ser entendida, portanto, como um código doador de sentido para o direito, que não precisa ser justo, necessariamente, mas, um direito injusto carece do suporte necessário para sustentar-se por muito tempo, haja vista sua perda de sentido ou sua dignidade intrínseca.

Assim, consideramos extremamente oportuno o pensamento de Tércio Sampaio Ferraz Jr., que harmoniza os enfoques sobre as relações entre Direito e Moral, sem as compartimentalizações comumente referidas nas comparações entre as duas ordens normativas.

Verificada a multiplicidade de relações que existem ou podem existir entre essas áreas, impende perpassar o debate árduo que se instala entre duas correntes filosóficas que se digladiam nos debates da Filosofia Moral. Trata-se das discussões sobre o universalismo e o relativismo axiológico, que estabelecem um contraponto entre a existência de preceitos absolutos e universais, juízos éticos prevalentes, ou a possibilidade apenas relativa de sustentação dos juízos éticos e morais, variáveis em razão da cultura.

Iniciaremos com as abordagens que entendem ser possível a formulação de verdades morais, juízos éticos universais e incontrastáveis. Trata-se de uma aproximação ao denominado universalismo axiológico.

\footnotetext{
${ }^{218}$ FERRAZ Jr., Tércio Sampaio. Introdução ao estudo do Direito: técnica, decisão, dominação. São Paulo: Atlas, 1994, p. 357.

${ }^{219}$ Ibid., pp.357-358.
} 


\subsection{Universalismo axiológico}

A ideia de sentidos absolutos de valor sempre encontra seu lugar nos debates éticos. Preconiza-se, nesse sentido, a existência de determinadas noções e preceitos fundamentais que devem ser buscados e preservados em razão da própria natureza humana, como algo bom, ou, em contraposição, ações e preceitos considerados maus, por si. Alguns autores, por exemplo, chegam a citar uma lista de proibições universais, que seriam consideradas por todos como naturalmente ruins, como assassinato, fraudes, crueldade, traição. Outros preceitos também são citados: a) alguém não deve agir de modo rude; b) deve ser cumprido o que foi prometido; c) não deve ser infligida dor a alguém etc ${ }^{220}$.

Norman M. Ford cita outros exemplos de ações que seriam intrinsecamente más: terrorismo, tortura, mutilação genital, bombardeamento de civilizações etc ${ }^{221}$.

Por outro lado, pode-se dizer que o homem representaria o sentido de unidade, capaz de centrar objetivos comuns. Por exemplo, fazer o bem, evitar o sofrimento seria algo que se impõe de modo universal, mesmo entre não humanos - o que pode sujeitar-se a um juízo crítico, de refutabilidade.

Uma ponderação interessante, que de certo modo se conecta às discussões sobre Direito, Moral e preceitos universais, diz respeito à existência de certas regras que toda sociedade deve ter para que se sustente de modo viável, o que é abordado com muita acuidade por Hart. Destacamos esse pensamento pelo fato de considerar as regras fundamentais.

$\mathrm{O}$ autor retoma a ideia de que haveria regulamentações comuns ao Direito e à Moral que representariam o conteúdo mínimo de um Direito Natural, estando presentes em todos os agrupamentos humanos que se desejam sustentáveis - numa concepção de aparente universalidade, como princípios de conduta reconhecidos amplamente. Como escreve Hart,

${ }^{220}$ HARMAN, Gilbert. THOMSON, Judith Jarvis. Moral relativism and moral objectivity. Oxford: Blackwell, 2003, pp.8-10. A lista é de Walzer, autor citado por Gilbert Harman. No entanto, Gilbert Harman critica essa tese, afirmando que algumas poucas sociedades aceitam uma proibição geral de matar ou causar dano a outras pessoas. Como escreve o autor, "Há sociedades nas quais um mestre é tido como alguém que tem um direito absoluto de tratar seus escravos, de qualquer modo que deseje, incluindo espancá-los arbitrariamente e matá-los" (tradução nossa). No original: "There are societies in which a "master" is thought to have an absolute right to treat his slaves in any way he chooses, including arbitrarily beating and killing them". As outras sentenças citadas, e que configurariam obrigações morais absolutas, são lembradas por Judith Jarvis Thomson.

${ }^{221}$ FORD, Norman M. The prenatal person: ethics from conception to birth. Reino Unido: Blackell, 2002, p. 22. 
há certas regras de conduta que qualquer organização social deve conter, para ser viável. Tais regras constituem de facto um elemento comum no direito e na moral convencional de todas as sociedades que progrediram até ao ponto em que ambos são distinguidos como formas diferentes de controle social ${ }^{222}$.

Elas são regras mínimas, representativas de uma formulação elementar social em sua estrutura, o que designa um conteúdo mínimo do Direito Natural. E,

na ausência deste conteúdo os homens, tais como são, não teriam uma razão para obedecerem voluntariamente a quaisquer regras; e, sem um mínimo de cooperação dada voluntariamente por aqueles que consideram ser seu interesse submeter-se às regras, e mantê-las, seria impossível a coerção dos outros que não se conformassem com tais regras ${ }^{223}$.

Basicamente, cinco são as regras representativas do conteúdo mínimo de Direito Natural. Em verdade, algumas partem de constatações, refletindo dados naturais: a) vulnerabilidade humana, o que ensejaria uma regra dita elementar para convivência entre homens, qual seja não matarás. Ela não deixa de se aproximar, quanto ao seu conteúdo, das ideias de não causar dor, sofrimento, como um valor absoluto.

Ademais, pode ser citada: b) a necessidade de uma igualdade aproximada entre os homens, não podendo existir indivíduos que sejam muito mais fortes e poderosos que todos os outros; c) a ideia de um altruísmo limitado reinante entre os seres humanos, o que de certo modo representa um meio-termo; d) existência de recursos limitados e, por fim, e) compreensão e força de vontade limitadas, que insere nas discussões a necessidade de sanção "não como motivo normal para a obediência, mas como uma garantia de que os que obedeceriam voluntariamente não serão sacrificados aos que não obedeceriam"224.

É necessário explicitar, porém, que essas regras mínimas não englobam todos os membros da sociedade, motivo pelo qual destacamos, pouco acima, uma aparente universalidade. Deveras, ressalta Hart, em seguida, que "embora uma sociedade, para ser viável, deva oferecer a alguns de seus membros um sistema de recíprocas abstenções não necessita, infelizmente, de oferecê-las a todos",225.

\footnotetext{
${ }^{222}$ HART, Herbert L. A. O conceito de Direito. Lisboa: Fundação Lacouste Gulbenkian, 2007, p. 209.

${ }^{223}$ Ibid., pp. 209-210.

${ }^{224}$ Ibid., pp. 210-215.

225 Ibid., p. 217.
} 
Interessa, no entanto, analisar alguns dos argumentos da existência de preceitos morais objetivamente válidos.

Alguns problemas se põem desde logo na sustentação de um juízo sobre a moral objetiva, como a inserção do homem na história, e as alternâncias do que em cada época se considera correto. É necessário indagar, pois, se apenas esse fato é capaz de afastar juízos morais que transcendem a própria época, ultrapassando o tempo e as fronteiras que separam os mais diferentes povos.

$\mathrm{Na}$ esteira de uma genealogia da Moral, é válido dizer que o sentido de "bom", no início, como adverte Nietzsche, não significava ação altruísta. Nestes termos, a noção de bom surge no sentido de "distinto quanto à alma", em oposição à idéia de "mau"226. Assim é também a distinção entre o nobre e o plebeu. Verifica-se, nessas oposições, um sentido dualista, que opõe o bom e o mau, o bem e o mal, com influências que se observa na origem de alguns vocábulos. A alternância de significados dos sentidos de bom e mau não seria um contra-argumento ao universalismo?

Há o entendimento de que, mesmo com toda a diversidade existente, haveria desejos universais, buscados por todos os membros da espécie, independentemente de seu local de nascimento, de seus costumes e do período histórico. Trata-se de juízos morais que, a todo lugar, poderiam ser considerados verdadeiros.

O sentido do verdadeiro é o que influenciará os adeptos de uma verdade interpretativa, passível de ser buscada no processo hermenêutico. Como encontrar, no entanto, a interpretação correta em determinado caso?

Numa interpretação sociológica dos valores, que se aproxima de uma visão universalista, autores há que entendem que os valores não se ligam a uma vontade individual de um determinado sujeito. Ao contrário, eles devem ser apreciados como um "fato da sociedade no seu todo como expressão de crenças ou desejos sociais (Gabriel Tarde) ou produtos da consciência coletiva (Émile Durkheim)",227.

A noção de consciência coletiva ganha força, baseando-se nela a concepção de valores prevalentes, que se impõe aos indivíduos participantes do corpo social.

\footnotetext{
${ }^{226}$ NIETZSCHE, Friedrich. A genealogia da Moral. Petrópolis: Vozes, 2009.

${ }^{227}$ REALE, Miguel. Filosofia do Direito. São Paulo: Saraiva, 1982, pp. 197-199. Na linha de Durkheim, “os valores obrigam e enlaçam nossa vontade, porque representam as tendências prevalescentes no todo coletivo, exercendo pressão ou coação exterior sobre todas as consciências individuais". Ademais, Reale cita a obra de outro autor (Davi), que procurou demonstrar "como na história da sociedade vão surgindo valores, que depois se impõem ao homem, com um caráter de objetividade e idealidade", ainda com base na ideia de uma consciência coletiva que se superpõe às consciências individuais.
} 
Ao assinalar o contorno do que considera o que seja a Ética, afirma Peter Singer, veementemente, o que ela não pode ser (tudo o que a Ética não é). Entre as ponderações que faz, salienta que ela não é relativa ou subjetiva. Ao analisar alguns argumentos sobre o relativismo ético, acentua que, nessa forma de análise, não há conflitos. Isto porque todas as bases são defensáveis, e assim qual razão haveria para discutir determinado assunto como a escravidão? Além disso, destaca o autor,

o relativista não pode, satisfatoriamente, explicar o não-conformista. Se a "escravidão é errada" significa "minha sociedade condena a escravidão", então alguém que vive numa sociedade que não condena a escravidão está cometendo um erro simples e factual ao afirmar que a escravidão é um erro ${ }^{228}$.

Esse raciocínio expõe um ponto nodal do relativismo: se tudo vale, as discussões perdem o sentido, e em prol da tolerância devem ser respeitadas as posturas divergentes, contrárias ao pensamento do outro interlocutor. É como se a recusa na transmissão de uma mensagem fosse acordada entre os sujeitos do discurso de modo plenamente possível.

Para o autor, a razão desempenha um papel importante para conformação de um pensamento que extrapole o subjetivismo e o relativismo, possibilitando o que denomina de raciocínio ético. Há, de certo modo, uma exigência de que ultrapassemos o individualismo. Argumenta ainda que "a ética exige que extrapolemos o 'eu' e o 'você' e cheguemos à lei universal, ao juízo universalizável, ao ponto de vista do espectador imparcial, ao observador ideal, ou qualquer outro nome que lhe demos",229.

$\mathrm{O}$ apelo à razão como fonte de um juízo ético universal deita raízes em Kant, na sua conhecida fórmula do imperativo categórico de lei universal, máxima que apela que façamos aos outros aquilo que desejamos tornar-se lei, aquilo que transcende o próprio indivíduo.

Peter Singer, em seus livros, destaca um preceito que, de certo modo, perpassa as ponderações do que considera um pensar ético: trata-se da igual consideração de interesses. Esse princípio, que deve ser levado em consideração na solução dos dilemas éticos, ultrapassa o pensamento egoístico, transcendendo uma resposta individual ao que

${ }^{228}$ SINGER, Peter. Ética prática. São Paulo: Martins Fontes, 2002, pp.12-14. Como se verifica em Singer, e conforme restará detalhado mais abaixo, são nucleares para compreensão de suas ideias o princípio da igual consideração de interesses e a noção de pessoa como sujeito moral.

${ }^{229}$ Ibid., pp. 20-23. 
seja considerado ético. Verifica-se, ademais, inegável influência do utilitarismo em sua obra, consideradas as várias vertentes de utilitarismo desenvolvidas ${ }^{230}$.

A circunstância de determinado fato ser culturalmente aceito em algum local do planeta, nessa visão, não significa que seja ético, se não se submete ao crivo da universalização da conduta. É necessário, pois, a consideração de outros interesses - dos outros sujeitos envolvidos no problema.

Não é só Singer que entre os filósofos morais defende a possibilidade de formulação de uma ética universal, objetiva. Assim também, com base nesse pensamento universalista, de objetividade moral, Judith Jarvis Thomson, autora do polêmico ensaio A defense of abortion, elabora sua tese segundo a qual "as assertivas morais são despropositadas a menos que seja possível descobrir algumas sentenças morais que sejam verdadeiras" (tradução nossa) ${ }^{231}$.

Partindo dessa premissa, é possível, segundo a autora, que entre as assertivas morais, haja aquelas cujo teor seja verdadeiro e aquelas cujo teor seja inegavelmente falso, daí se dizer que a moralidade é objetiva, dada a formulação de juízos que podem sujeitar-se ao crivo da verdade e da falsidade, o que contraria, por seu turno, a tese do ceticismo moral.

O problema que se apresenta nesse passo diz respeito ao critério que deve ser utilizado para avaliar a correção ou verdade de uma sentença moral. Uma dificuldade que se assenta em problemas cognitivos é saber como um juízo subjetivo, tomado por um indivíduo em determinada situação, estende-se a um universo de pessoas. É perquirir como, da pluralidade, pode ser extraída uma unidade que convenha e que se adeque ao juízo que outros sujeitos morais fariam diante desta mesma situação.

Alguns adeptos da objetividade moral entendem que há algo que se sobrepõe à mera somatória de avaliações individuais, de interesses individualistas, e que de certo modo os transcende. Algo que representa interesses comuns, sentimentos compartilhados por todo mundo.

Por analogia, pode-se pensar na teoria contratualista de Rousseau, em que a vontade geral não se reduz à soma das vontades individuais - e que se impõe, objetivamente, como valiosa para a humanidade.

\footnotetext{
${ }^{230}$ Verificar, nesse sentido, as seguintes obras de Peter Singer: Rethinkink Life and Death (sem tradução para o português), Ética Prática, Libertação Animal, Unsanctifying Human Life (sem tradução para o português).

${ }^{231}$ HARMAN, Gilbert. THOMSON, Judith Jarvis. Moral relativism and moral objectivity. Oxford: Blackwell, 2003, pp.67-68. No original: "Moral Assessment is pointless unless it is possible to find out about some moral sentences that they are true".
} 
Para sustentar o universalismo ético, é preciso refutar o ceticismo que usualmente está na base das teses contrárias à possibilidade de um juízo objetivo. Tal ceticismo pode ser global ou local, como ensina Judith Jarvis Thomson. Além disso, o ceticismo moral é só uma das variedades que se verificam no mundo, podendo se falar em ceticismo sobre o mundo físico, sobre o passado e o futuro, sobre outras mentes, sobre a causalidade, e assim por diante ${ }^{232}$.

Pode-se especificar, de início, os argumentos epistemológicos do relativismo moral, para, em seguida, refutá-los - corroborando o universalismo. O primeiro argumento relativista a ser refutado parte de três premissas, podendo ser esquematizado de modo lógico.

A primeira premissa (I) estabelece que as asserções ou sentenças morais não podem ser vinculadas ou apreendidas de sentenças factuais. A segunda premissa (II) encerra a assertiva de que o único modo de descobrir que uma sentença moral é verdadeira é dar-se conta que certas sentenças fáticas são verdadeiras, tomando a sentença moral como conclusão das sentenças fáticas (II). Por fim, se acreditamos em uma sentença "S" pela descoberta de que outras sentenças "SS" são verdadeiras, tomando a sentença "S" como conclusão das outras, "S" somente será verdadeira se as outras o forem (III) ${ }^{233}$.

Observa-se, de plano, uma aparente rachadura e separação entre dois mundos: o mundo fático e o mundo moral. Se se reconhece uma separação absoluta, a premissa "I" poderia ser considerada verdadeira, não podendo os juízos morais serem aferidos do mundo fático.

Entretanto, como observa Judith Jarvis Thomson, defensora do universalismo moral, há filósofos morais que discordam dessa separação entre sentenças morais e sentenças fáticas. Deveras, alguns chegam ao ponto de equipará-las, não havendo que se falar em um abismo entre uma e outra ${ }^{234}$. Assim, os juízos morais podem ser apreendidos a partir de sentenças fáticas, o que afastaria o vigor da premissa $\mathrm{I}$, que se alicerça na separação entre as esferas. Seria pensar, também, que não há fosso abissal entre as esferas do ser e do dever-ser, representando cada qual a esfera do mundo fático e a esfera dos valores.

Porém, como recorda Miguel Reale, desde Kant se pode declarar verdadeira a afirmação de que do mundo do ser não se passa para o dever-ser. Da verificação de que um

\footnotetext{
${ }^{232}$ Ibid., p. 70.

${ }^{233}$ Ibid., pp. 69-70.

${ }^{234}$ Ibid., p. 72.
} 
fato "é" não resulta que ele "deva ser", o que é não envolve, como nexo necessário, aquilo que deve ser. O dever-ser, muitas vezes, é o contrário daquilo que é ${ }^{235}$.

Para refutar a premissa cética II, segundo a qual somente se pode dizer que uma sentença moral é verdadeira a partir de uma sentença factual, aduzem os autores que não há, necessariamente, essa relação. Não há, portanto, essa dependência de juízos, de forma que há quem vislumbre, inclusive, a possibilidade de uma intuição moral, um certo insight de verdades morais que não dependeriam da passagem do pensamento pelos juízos fáticos ${ }^{236}$.

Por fim, quanto à premissa III, o só fato de determinadas sentenças "SS" serem verdadeiras não garante que a conclusão "S" seja verdadeira. Poderá, no entanto, indicar uma evidência para que a sentença "S" seja verdadeira. Para exemplificar, o fato de parecer, sentir e ouvir como se estivesse em frente a uma fogueira ou lareira não necessariamente pode referir-se a tal fato, mas constitui, por certo, uma evidência de que se possa realmente estar sentado em frente a uma fogueira ou a uma lareira. A autora analisa, ainda, na ordem de argumentos epistemológicos, sob influência da análise lógico-formal e material, outras teses que embasariam o ceticismo axiológico. Discorre longamente sobre outro raciocínio trazido à colação pelos defensores do ceticismo moral, também baseado em três premissas, assim estabelecidas: I) não há uma sentença moral cuja veracidade pudesse explicar a verdade de uma sentença factual; II) a verdade de uma sentença factual é evidência para uma sentença moral somente se a verdade da sentença moral pudesse explicar a verdade de uma sentença factual e III) o único modo de descobrirmos que uma sentença moral é verdadeira é descobrir que certas sentenças factuais são verdadeiras, em que a verdade das sentenças factuais é evidência para a sentença moral, tomando-a como conclusão das sentenças fáticas ${ }^{237}$.

Nessa empreitada de construção de pensamento, predominam os argumentos filosóficos que se destacam pela abstração, daí denominá-los de epistemológicos, tornando necessária uma acurada apreensão do sentido de cada uma das premissas descritas.

A questão que se coloca, nos debates trazidos por Judith Jarvis Thomson, diz respeito à indagação quanto à possibilidade de uma sentença ou juízo moral explicar a

\footnotetext{
${ }^{235}$ REALE, Miguel. Filosofia do Direito. São Paulo: Saraiva, 1982, p. 201; KELSEN, Hans. Teoria Pura do Direito. São Paulo: Martins Fontes, 2009, p. 20. Como destaca Kelsen, "o valor, como dever-ser, colocase em face da realidade, como ser; valor e realidade - tal como dever-ser e ser - pertencem a duas esferas diferentes".

${ }^{236}$ HARMAN, Gilbert. THOMSON, Judith Jarvis. Moral relativism and moral objectivity. Oxford: Blackwell, 2003, p. 72.

${ }^{237}$ Ibid., p. 73. Tradução nossa.
} 
verdade de uma sentença fática. Para alguns pensadores, este raciocínio mostra-se possível, de modo que um fato moral (moral fact) explique um fato não moral (nonmoral fact). Para análise desta questão, desenvolvem-se nesse ponto os argumentos de Nicholas Sturgeon, um dos maiores defensores da ideia de que a verdade de uma sentença moral seria capaz de explicar a verdade de uma sentença fática sobre um ser humano ${ }^{238}$.

Os debates sobre esse argumento são deveras polêmicos e engendram certa complexidade. Deste modo, mesmo recorrendo a exemplos práticos, que ilustrariam a operacionalidade ou fragilidade de cada uma das premissas, ainda assim verifica-se o predomínio da abstração. De fato, as suposições presentes nos exemplos, que têm por função dar concretude ao argumento teórico, são quase sempre condicionais, e as hipóteses trazidas nas ilustrações fictícias, com pouquíssimo lastro na realidade.

Outra tese comumente mencionada nos debates que rejeitam o universalismo e a existência de juízos morais objetivos, portanto, contrários à objetividade moral, diz respeito ao emotivismo.

Esta corrente crítica é, na verdade, formada por um conjunto inter-relacionado de teses. A primeira, que constitui uma espécie de tese semântica, parte do princípio de que nem todas as sentenças podem ter valor de verdade ou falsidade. Nesse grupo, estariam incluídas as sentenças que exprimem um valor moral. Assim, I) um dever moral não pode ser avaliado em termos de falsidade ou verdade, o que atingiria a pretensão de formular-se uma moral objetiva. Esta constitui a primeira premissa do raciocínio, que é criticada por Judith Jarvis Thomson, pois se as sentenças morais não podem ser avaliadas em termos de verdade ou falsidade, nem mesmo haveria como se falar em evidências ${ }^{239}$.

Ora, como escrevem alguns autores da Filosofia do Direito, as normas não podem ser analisadas em termos de verdade ou falsidade, e sim tão-somente as proposições que as descrevem. A norma jurídica pode ser considerada válida ou inválida, nunca verdadeira ou falsa, atributo das proposições ${ }^{240}$. No caso das normas morais, pode ser elaborado semelhante raciocínio, pois, assim como as normas jurídicas, são passíveis de formulação em termos de dever-ser e, juntamente às primeiras, incluem-se na categoria de normas sociais.

${ }^{238}$ Ibid., p. 76.Ver, para maior compreensão dos argumentos episteológicos, as ideias desenvolvidas nas páginas 77 a 94.

${ }_{239}^{23}$ Ibid., p. 96.

${ }^{240}$ KELSEN, Hans. Teoria Pura do Direito. São Paulo: Martins Fontes, 2009, p. 82. Nas palavras do autor, "a distinção revela-se no fato de as proposições normativas formuladas pela ciência jurídica, que descrevem o Direito e que não atribuem a ninguém quaisquer deveres ou direitos, poderem ser verídicas ou inverídicas, ao passo que as normas de dever-ser, estabelecidas pela autoridade jurídica - e que atribuem deveres e direitos aos sujeitos jurídicos - não são verídicas ou inverídicas mas válidas ou inválidas (...)”. 
Em sequência, verificamos as demais premissas: II) não existem fatos morais; III) alguém que faça um juízo moral na verdade está apresentando uma atitude e, conectado a esta última premissa, IV) não existem crenças morais, mas simplesmente atitudes contrárias ou favoráveis. Consoante a interpretação de Judith Jarvis Thomson, também poderia ser extraída da obra de Hume uma forma de emotivismo: o raciocínio embasa-se na noção de que o que chamamos de crença moral não passaria de uma atitude, de uma propensão favorável ou desfavorável em relação a alguma coisa ${ }^{241}$. Enfim, para algumas questões, os universalistas não logram contraposições consistentes.

Ainda sob um enfoque que tem inspirado universalistas ao redor do globo, podemos citar Kant, filósofo cujas ideias permeiam os debates éticos e quase sempre são tomadas como bandeira para defesa de certa moralidade tomada em sentido absoluto: um verdadeiro argumento de autoridade que tem a pretensão de sufocar as teses contrárias.

Na sua Fundamentação da Metafísica dos costumes, estão presentes algumas dessas ideias, que merecem ser lembradas pela influência que exercem, inclusive no pensamento jurídico atual, especialmente no que concerne à dignidade da pessoa humana.

É célebre a menção à necessidade de se considerar o homem como fím em si mesmo, a que se atribui uma dignidade, ao passo que às coisas atribui-se um preço: cuidase da separação entre pessoas e coisas, que é retomada no pensamento de Kant sob uma ótica em que à razão se atribui um papel muito importante. Deveras, como destaca Ronaldo Porto Macedo Jr. acerca de Kant,

o seu projeto filosófico, na esteira do racionalismo moderno, procurava elaborar uma ciência e uma moral fundadas na Razão e a razão é não apenas fonte de conhecimento, como também é a única fonte de conhecimentos necessários e universais, porquanto a $_{\text {priori }}^{242}$.

241 HARMAN, Gilbert. THOMSON, Judith Jarvis. Moral relativism and moral objectivity. Oxford: Blackwell, 2003, p. 95.

${ }^{242}$ MACEDO Jr. Ronaldo Porto. Kant e a crítica da razão: moral e direito. In: (coord). Curso de Filosofia Política: do nascimento da Filosofia a Kant. São Paulo: Atlas, 2008, pp. 427 e 434. KANT, Immanuel. Fundamentação da Metafísica dos costumes. Lisboa: Edições 70, 2008, p. 48. Para Kant, "todos os conceitos morais têm sua sede e origem completamente a priori na razão, e isto tanto na razão humana mais vulgar como na especulativa em mais alta medida; que não podem ser abstraídos de nenhum conhecimento empírico e por conseguinte puramente contingente; que exactamente nesta pureza da sua origem reside sua dignidade para nos servirem de princípios práticos supremos; que cada vez que lhes acrescentemos qualquer coisa de empírico diminuímos em igual medida a sua influência e o valor ilimitado das acções; que não só o exige a maior necessidade sob o ponto de vista teórico quando se trata apenas de especulação, // mas que é também da maior importância prática tirar da razão pura os seus conceitos e leis, expô-los com pureza e sem mistura, e mesmo determinar o âmbito de todo este conhecimento racional prático mas puro, isto é, toda a capacidade da razão pura prática”. 
Kant diferencia, no início de sua Fundamentação da Metafísica dos costumes, as ações conforme o dever e as ações por dever. Somente a estas últimas pode ser atribuída a genuína característica de moralidade, ou seja, apenas elas possuem um conteúdo moral. E, no raciocínio que faz, o que denomina de boa vontade é a vontade por dever.

Para exemplificar, o autor toma a situação de respeito à vida. Assim, alguém que se abstém de violar a própria vida, mantendo-a por inclinação imediata, nada mais faz do que agir conforme o dever de preservar a vida, e nisso nenhum valor moral se observa. No entanto, alguém que perante as agruras da vida, em meio ao sofrimento que o faz desejar a morte, ainda assim mantém sua vida, contrariando suas intenções e inclinações, age por dever. Essa ação pode ser considerada com um conteúdo moral ${ }^{243}$.

E é com base nesse pensamento que Kant formula a ideia de uma de suas máximas. Como escreve o filósofo,

\begin{abstract}
se uma acção realizada por dever deve eliminar totalmente a influência da inclinação e com ela todo o objecto da vontade, nada mais resta à vontade que a possa determinar do que a lei objectivamente, e subjectivamente, o puro respeito por esta lei prática, e por conseguinte a máxima (*) que manda obedecer a essa lei, mesmo com prejuízo de todas as minhas inclinações (...) o valor moral da acção não reside, portanto, no efeito que dela se espera; também não reside em qualquer princípio da acção que precise de pedir o seu móbil a este efeito esperado $^{244}$.
\end{abstract}

A fórmula kantiana baseia-se numa ideia de ação que se conforme a uma lei universal. Assim, "devo proceder sempre de maneira que eu possa querer também que a minha máxima se torne uma lei universal" ${ }^{, 45}$.

É na segunda seção de sua Fundamentação da Metafísica dos costumes, entretanto, que podemos encontrar os fundamentos reiteradamente propagados de uma tese universalista.

Cuida-se de aprofundar a concepção de um supremo princípio da moralidade, o que remete à noção dos imperativos. Estes, tais como apresentados por Kant, significam um princípio objetivo, um mandamento da razão, e representam a relação entre a lei da razão e uma vontade, ordenando-a.

\footnotetext{
${ }^{243}$ KANT, Immanuel. Fundamentação da Metafísica dos costumes. Lisboa: Edições 70, 2008, pp. 28-30.

${ }^{244}$ Ibid., pp. 31-32.

${ }^{245}$ Ibid., p. 33.
} 
Essa ordenação pode dar-se de dois modos, seja através do imperativo hipotético, seja por meio de imperativo categórico. Este "declara a acção como objectivamente necessária por si, independentemente de qualquer intenção, quer dizer sem qualquer outra finalidade, vale como princípio apodíctico (prático)" ${ }^{246}$.

É esse imperativo - o categórico - que se destaca para a compreensão de uma tese universalista da moral, sendo denominado pelo filósofo de imperativo da moralidade.

O imperativo categórico representa uma lei prática, que ordena determinado comportamento e, alçado como princípio da moralidade, é entendido como uma proposição sintética-prática a priori - o que releva, pois, o papel racional na compreensão e estabelecimento desse imperativo.

Expressando-o numa fórmula, Kant diz que ele é um só. Como escreve,

o imperativo categórico é portanto só um único, que é este: Age apenas segundo uma máxima tal que possas ao mesmo tempo querer que ela se torne lei universal (...) Age como se a máxima da tua aç̧ão se devesse tornar, pela tua vontade, em lei universal da natureza ${ }^{247}$.

Destaca Ronaldo Porto Macedo Jr. que “o imperativo categórico não nos propõe nenhum fim exterior, mas tão somente a máxima de que devo agir conforme a uma lei geral" ${ }^{248}$. Estabelecida essa premissa basilar, depreende-se com nitidez a ideia universalista.

Kant passa então às considerações sobre a inserção do homem no "Reino dos Fins". Nesse sentido,

o conceito segundo o qual todo o ser racional deve considerar-se como legislador universal por todas as máximas da sua vontade para, deste ponto de vista, se julgar a si mesmo e às suas acções, leva a um outro conceito muito fecundo que lhe anda aderente e que é o de um Reino dos Fins ${ }^{249}$.

\footnotetext{
${ }^{246}$ Ibid., pp. 52-53.

${ }^{247}$ Ibid., p. 62.

${ }^{248}$ MACEDO Jr. Ronaldo Porto. Kant e a crítica da razão: Moral e Direito. In: Filosofia Política: do nascimento da filosofia a Kant. São Paulo: Atlas, 2008, p. 441.

${ }^{249}$ KANT, Immanuel. Fundamentação da Metafísica dos costumes. Lisboa: Edições 70, 2008, p. 79.
} 
Assim, todo homem deve ser considerado um fim em si mesmo, e a ele atribui-se uma dignidade, ao passo que às coisas atribui-se um preço. Eis o motivo de vedar a instrumentalização do homem, que jamais pode ser considerado um meio. Nesse ponto,

a moralidade é a única condição que pode fazer de um ser racional um fim em si mesmo, pois só por ela the é possível ser um membro legislador no reino dos fins. Portanto a moralidade, e a humanidade enquanto capaz de moralidade, são as únicas coisas que têm dignidade ${ }^{250}$.

Por fim, completa a seção segunda com alguns apontamentos sobre a autonomia, que considera um princípio supremo da moralidade, pois está na esteira de suas considerações universalistas. Afirma o filósofo que a

autonomia de vontade é aquela sua propriedade graças à qual ela é para si mesma a sua lei (independentemente da natureza dos objectos do querer). $\mathrm{O}$ princípio da autonomia de vontade é portanto: não escolher senão de modo a que as máximas da escolha estejam incluídas simultaneamente, no querer mesmo, como lei universal ${ }^{251}$.

Enfim, a razão perpassa praticamente todas as discussões.

Convém salientar que a tese do universalismo axiológico tem granjeado muitos adeptos atualmente, especialmente na seara do Direito Internacional dos direitos humanos, em que se propugna a ideia de direitos e preceitos fundamentais absolutos a serem implementados para toda humanidade.

Busca-se construir uma rede de proteção internacional que tem ao seu centro a pessoa humana, independentemente da nacionalidade e cultura que, apesar de serem respeitadas, não podem justificar que atrocidades e ofensas aos seres humanos sejam perpetradas, ressaltando o dever de tolerância à diversidade existente no mundo. Há direitos mínimos dos povos, que devem ser observados e implementados com o auxílio de toda comunidade internacional. Mas não seria incoerente a pretensão de afirmar direitos universais, com tanta diferença fática, facilmente verificável nas diversas partes do globo?

Assim, os estudiosos do Direito Internacional dos direitos humanos, em sua maioria, entendem mais adequada à proteção dos direitos humanos a tese universalista, já

\footnotetext{
${ }^{250}$ Ibid., p. 81.

${ }^{251}$ Ibid., pp. 89-90.
} 
que o relativismo poderia justificar - em nome desta diversidade de costumes, crenças e culturas - ofensas sérias, a dor e a morte de milhares de seres humanos, não podendo haver qualquer intromissão para combater, por exemplo, mutilações, tortura, assassinatos.

Aliás, a pretensão universalista pode ser facilmente notada em tratados internacionais, ou mesmo em declarações de direitos que se referem aos membros de uma família humana, como a Declaração Universal dos Direitos Humanos, de 1948, que utiliza terminologicamente as expressões "todos" e "ninguém”, como destaca Flávia Piovesan, ao afirmar que essa Declaração de Direitos consolida a ideia de uma ética universal ${ }^{252}$.

Também a Declaração e Programa de Ação de Viena, de 1993, teria consagrado a tese universalista dos direitos humanos, de modo a corroborar a característica já afirmada acerca da universalidade.

Como se verifica no referido tratado,

5. Todos os direitos humanos são universais, indivisíveis interdependentes e inter-relacionados. A comunidade internacional deve tratar os direitos humanos de forma global, justa e equitativa, em pé de igualdade e com a mesma ênfase. Embora particularidades nacionais e regionais devam ser levadas em consideração, assim como diversos contextos históricos, culturais e religiosos, é dever dos Estados promover e proteger todos os direitos humanos e liberdades fundamentais, sejam quais forem seus sistemas políticos, econômicos e culturais $^{253}$ (destaque nosso).

Enfim, apesar da diversidade cultural e das particularidades nacionais e regionais, a universalidade é reconhecida como qualidade dos direitos humanos, que são considerados de modo global.

A crítica que se faz diz respeito ao fato de que os direitos e garantias universais, que devem ser protegidos e implementados a todos os seres humanos, teriam origem em padrões ocidentais, de modo que os países dissonantes seriam impelidos a aceitar a imposição daquilo considerado correto por outros povos.

Do ponto de vista histórico, seria equivalente à imposição, aos vencidos, das ideias e políticas defendidas pelos vencedores, e não propriamente uma preocupação com a

${ }^{252}$ PIOVESAN, Flávia. Direitos humanos e o Direito Constitucional Internacional. São Paulo: Saraiva, 2009, p. 139.

${ }^{253}$ Disponível em: http: <//www.pge.sp.gov.br/centrodeestudos/bibliotecavirtual/instrumentos/viena.htm>; acesso em: 12 de agosto de 2010. 
sociedade que deve acatar as regras consideradas universais, em razão do pertencimento à espécie humana. Como lembra Flávia Piovesan,

\begin{abstract}
na análise dos relativistas, a pretensão de universalidade desses instrumentos simboliza a arrogância do imperialismo cultural do mundo ocidental, que tenta universalizar as próprias crenças. A noção universal de direitos humanos é identificada como uma noção construída pelo modelo ocidental. O universalismo induz, nessa visão, à destruição da diversidade cultural ${ }^{254}$.
\end{abstract}

No entanto, esse argumento é refutado, pois na visão universalista que os direitos humanos albergam não fica escamoteada a diversidade cultural. $\mathrm{O}$ respeito à diversidade dos povos e às peculiaridades várias pode ser verificado na própria tendência de especificação de alguns sujeitos no Direito Internacional ${ }^{255}$, com proteção às diferenças através de mecanismos compensatórios, em que algumas pessoas são destinatárias de todo um arcabouço normativo protetivo, de modo que a igualdade não seja uma forma de nivelamento absoluto, mas sim uma possibilidade de tratar desigualmente os desiguais.

Fala-se, portanto, que a universalidade é enriquecida pela diversidade cultural, sendo preciso permitir "variações culturais no modo e na interpretação de direitos humanos, mas é necessário insistir na universalidade moral e fundamental. Os direitos humanos são, para usar uma apropriada frase paradoxal, relativamente universais" 256 .

A perspectiva multicultural é tomada sob um viés de diálogo intercultural, e não de confronto. Fala-se, assim, em um multiculturalismo emancipatório, universalismo pluralista e em um universalismo como ponto de chegada.

Dessa maneira, na medida em que todas as culturas possuem concepções distintas de dignidade humana, mas são incompletas, deve ocorrer uma tomada de consciência dessas incompletudes culturais mútuas, como pressuposto para um diálogo intercultural ${ }^{257}$.

No máximo, é de se aceitar um universalismo como projeto, e não como um fato verificável no mundo. Em termos de estimativa, desejo de concretização, pode-se dizer que

\footnotetext{
${ }^{254}$ PIOVESAN, Flávia. Direitos humanos e o Direito Constitucional Internacional. São Paulo: Saraiva, 2009, p. 153. A autora discorda da tese relativista.

${ }^{255}$ BOBBIO, Norberto. A era dos direitos. Rio de Janeiro, Elsevier, 1992, pp.62-63. "Além de processos de conversão em direito positivo, de generalização e de internacionalização, aos quais me referi no início, manifestou-se nestes últimos anos uma nova linha de tendência, que se pode chamar de especificação; ela consiste na passagem gradual, porém cada vez mais acentuada, para uma ulterior determinação dos sujeitos titulares de direitos".

${ }^{256}$ PIOVESAN, Flávia. Direitos humanos e o Direito Constitucional Internacional. São Paulo: Saraiva, 2009, pp.154-155.

${ }^{257}$ Ibid., p.156.
} 
a tese universalista é louvável, mas sua implementação encontra obstáculos insuperáveis, correndo mesmo o risco de imposição de sentidos e preceitos não objetivos e universais, mas totalitários. Cremos que, no máximo, pode-se conceber, numa sociedade ou mesmo em termos globais, valores historicamente dominantes, mas não fundamentos absolutos e imutáveis.

Finalmente, convém trazer à colação os ensinamentos de Kelsen a respeito da possibilidade de formulação de valores objetivos.

De início, afirma que somente sobre um fato da ordem do ser pode-se formular um juízo acerca da sua valia. Exemplifica com a correspondência de uma determinada conduta à norma que a prescreve ${ }^{258}$.

Para Kelsen, como será visto adiante, não há que se falar em uma relação tão estreita entre o Direito e a Moral de modo que o Direito deva ser moral. Nesse caso, estaria sendo adotada uma concepção de Moral absoluta, totalmente refutada pelo autor ${ }^{259}$.

Agora faz-se necessário destacar o outro lado da discussão, que também apresenta argumentos coesos nos debates morais.

\subsection{Relativismo axiológico}

Após a análise dos argumentos arrolados pelos defensores do universalismo moral, convém traçar o panorama do debate moral enquadrado pelos relativistas, que sustentam ser impossível o delineamento de verdades morais, ou juízos éticos absolutos que deveriam ser buscados como verdades inatacáveis. Ao contrário, o pluralismo é o que dá vigor.

A tese relativista, na visão de Gilbert Harman, preocupa-se em como as coisas são e não são. Não há algo bom, correto ou justo em absoluto, de modo que as avaliações dependem sempre de um parâmetro avaliativo, segundo os valores de determinada pessoa que assim considere, conforme será esclarecido mais abaixo ${ }^{260}$.

\footnotetext{
${ }^{258}$ KELSEN, Hans. Teoria Pura do Direito. São Paulo: Martins Fontes, 2009, pp. 19-20. "Se o valor é construído por uma norma objetivamente válida, o juízo que afirma que um quid real, uma conduta humana efetiva é "boa", isto é, valiosa, ou "má", isto é, desvaliosa, exprime e traduz que ela é conforme a uma norma objetivamente válida, ou seja, que deve ser (tal como é), ou que contradiz uma norma objetivamente válida, quer dizer, não deve ser (tal como é)". Há uma diferenciação feita pelo autor entre uma valoração objetiva e uma valoração subjetiva. A primeira pode ser compreendida como boa, se há uma correspondência da conduta com uma determinada norma válida. Ou má, se em desacordo com uma norma válida. Já uma valoração subjetiva tem relação com o desejo de determinado sujeito, que valora algo como bom ou mau. ${ }^{259}$ Ibid., p. 78.

${ }^{260}$ HARMAN, Gilbert. THOMSON, Judith Jarvis. Moral relativism and moral objectivity. Oxford: Blackwell, 2003, p. 17.
} 
O mundo é puro movimento, sendo o relativismo axiológico apenas uma faceta da mutabilidade perene, das mudanças contínuas verificadas na realidade fática. Os juízos morais, é indubitável, movem-se no tempo, refletindo de modo dinâmico a própria evolução humana. Talvez no confronto entre os pensamentos dos filósofos Parmênides e Heráclito já se pudesse notar certa disputa acerca da estabilidade das coisas, daquilo que é e a constância e fluidez das coisas.

As alterações legais que podem sedimentar os reclamos e anseios sociais não são fósseis normativos, existentes desde sempre. Uma avalanche legislativa desprende-se a todo momento das penas dos legisladores, soterrando regras e preceitos feitos para durar, mas que em pouco tempo podem tornar-se anacrônicos e propulsores de injustiças.

Diante disso, podem surgir movimentos que vão desde a rejeição da autoridade normativa ou até mesmo desconfirmadores da autoridade instituída, quando a autoridade deixa de ser reconhecida como tal. Podemos aventar, ainda, a ocorrência de movimentos que se pautam na desobediência civil e, em determinado grau, a substituição paulatina da ordem normativa.

Em um ou outro país pode-se apreender ordenamentos com leis que foram promulgadas há algum tempo, porém, mesmo assim, o papel interpretativo das cortes e dos tribunais dá novo realce a regras, contrariando a própria literalidade, que deve ser entendida de outro modo. Fala-se, nesse caso, que a interpretação alcançará o sentido da norma que mais se coaduna com as experiências e anseios de determinada sociedade, de modo dinâmico. A interpretação dá vida ao direito positivado e de certo modo atualiza o sentido normativo.

O que era já não é mais. O lapso temporal é suficiente para corroborar essa assertiva, de maneira a confirmar, portanto, que a relatividade é histórica. Situados na história, os valores refletem sensações, medos, vontades e estímulos de uma época, durando certo tempo, longo ou não, podendo se redefinir para adequar-se a novas eras. Tanto é assim que alguns preceitos tidos como bons, pois ligados à nobreza, passaram à condição oposta quando uma nova concepção de mundo emergiu.

É o que se depreende da análise feita por Nietzsche, em sua Genealogia da Moral, quando se refere à emancipação dos escravos da moral. Como escreve o filósofo,

a rebelião dos escravos da moral começou quando o ressentimento chegou a produzir valores (...). Enquanto toda a moral aristocrática nasce de uma triunfante afirmação de si própria, a moral dos escravos opõe um "não" a tudo o 
que não lhe é próprio, que lhe é exterior, que não é seu; este "não" é o seu ato criador $^{261}$.

Verifica-se uma oposição entre "os bons", "os formosos", "os felizes" e "os maus", "baixos”, “desgraçados”. E, “os 'bem nascidos' tinham o sentimento de serem os 'felizes', e não tinham necessidade de construir artificialmente a sua felicidade, comparando-se com seus inimigos e enganando-se a si mesmo como faziam os rancorosos"262.

Curiosamente, o mal e o maligno, nessa moral de ressentimento, ensina Nietzsche, são justamente o que significa o bom na outra moral (o nobre, o bom, o que governa). Muda-se, pois, o prisma do olhar para a classificação daquilo que é mau e aquilo que é bom $^{263}$.

Pode-se dizer que as diferenças são parte de um mundo tão vasto; onde se faça possível a ocupação humana, criam-se determinados hábitos, costumes, tradições, e tudo mais que se molda às peculiaridades étnicas, religiosas, locais. Enfim, o ser humano, apesar de um código genético humano, de um ser biológico pertencente à espécie Homo sapiens, é capaz de instaurar na terra uma pluralidade que reflete a personalidade de cada um: uma personalidade única e irrepetível.

A comunicação global foi potencializada ao máximo nas últimas décadas pela evolução tecnológica e possibilitou contatos em questão de segundos de um polo ao outro do mundo. Se por um lado ela é capaz de demolir fronteiras e pôr em contato tanta diversidade, até mesmo de modo beligerante e não pacífico, que pode ter por razão justamente a diferença, por outro não elimina os traços peculiares de cada lugar, de cada representação cultural existente no planeta.

O relativismo é, pois, espacial e cultural, e por mínimas que sejam, as diferenças locais são visíveis e ostentam sua importância ${ }^{264}$. De fato cada vez mais se fala em direitos das minorias, pugnando-se a proteção de grupos desfavorecidos - sob os mais variados aspectos - de modo que no âmbito internacional diversos tratados têm sido celebrados para propiciar mecanismos de igualação entre as pessoas ${ }^{265}$.

${ }^{261}$ NIETZSCHE, Friedrich. A genealogia da Moral. Petrópolis: Vozes, 2009, p. 41.

${ }^{262}$ Ibid., p. 42.

${ }^{263}$ Ibid., p. 44.

${ }^{264}$ HARMAN, Gilbert. THOMSON, Judith Jarvis. Moral relativism and moral objectivity. Oxford: Blackwell, 2003, p. 8

${ }^{265}$ Cita-se, no plano internacional, por exemplo, a Convenção sobre a Eliminação de todas as formas de Discriminação contra a Mulher, a Convenção sobre os Direitos da Criança, a Convenção Internacional sobre a Proteção dos Direitos de Todos os Trabalhadores Migrantes e dos Membros de suas Famílias, a Convenção sobre os Direitos das Pessoas com Deficiência etc. Ver, nesse sentido, os inúmeros tratados e convenções 
Ações afirmativas, como mecanismos de discriminação positiva, surgem para compensar tratamentos prejudiciais que trouxeram consequências negativas históricas. Ainda assim, não se tem por escopo a eliminação das diferenças existentes, que, pelo contrário, representam um fator de pluralismo no mundo atual, em que o diálogo e a tolerância mantêm-se, ainda que contraditoriamente, nos discursos dos representantes dos mais diversos países.

Como decorrência lógica do relativismo que se verifica na História e nas mais diferentes localidades, situa-se o relativismo axiológico, que reflete a diversidade estrutural dos povos, o momento em que se vive e o sentido que se busca para a própria vida e para a sociedade em que o indivíduo se insere. Nesses termos, o aborto é uma questão de desacordos, ou mesmo de divergências éticas históricas, não havendo uniformidade de opiniões quanto à sua prática. É patente que os sujeitos e partidos dessa discussão não chegaram a bom termo de convencer uns aos outros sobre uma solução ao problema do aborto $^{266}$.

Muitas são as questões e interesses presentes no momento em que a mulher está diante de uma gravidez que deseja interromper. Inúmeras consequências também, o que alimenta as divergências.

No campo da Bioética, a ideia de uma ética universal acaba fracassando. Por certo,

\begin{abstract}
a tentativa de sustentar um equivalente secular do monoteísmo cristão ocidental, por meio da revelação de uma única moral e narrativa metafísica da realidade, fragmentou-se em um politeísmo de perspectivas, com seu caos de diversidade moral e sua cacofonia de numerosas narrativas morais concorrentes. Tal circunstância, como condição sociológica, refletindo nossas limitações epistemológicas, define a pós-modernidade. A racionalidade secular surge triunfante. Mas transformou-se em muitas racionalidades. Não está claro se ela pode proporcionar orientação moral ou metafísica ${ }^{267}$.
\end{abstract}

analisados por Flávia Piovesan: PIOVESAN, Flávia. Direitos humanos e o Direito Constitucional Internacional. São Paulo: Saraiva, 2009.

${ }^{266}$ TOOLEY, Michael; WOLF-DEVINE, Célia; DEVINE, Philip E.; JAGGAR, Alison M. Abortion: three perspectives. New York: Oxford, 2009, prefácio, p. xi. "Os múltiplos partidos no debate do aborto têm sido manifestamente inaptos a convencer um ao outro ou alcançar um acordo mutuamente aceitável depois de mais de trinta anos de um debate público apaixonado" (tradução nossa). No original: "The multifarious parties to the abortion debate have been manifestly unable to convince one another or reach a mutually acceptable compromise after more than 30 years of impassioned public debate".

${ }^{267}$ ENGELHARDT Jr., H. Tristam. Fundamentos da Bioética. São Paulo: Loyola, 2004, p. 30. 
Cabe ressaltar que divergências podem existir a respeito de princípios morais, da melhor decisão a ser tomada em determinado caso; o que se considera justo pode variar por muitas razões. As controvérsias morais têm, portanto, causas várias.

Como destacam Tom L. Beauchamp e James F. Childress, a divergência moral pode emergir de: a) controvérsias fáticas; b) o destinatário de proteção da norma (abrangência quanto ao sujeito que o comando normativo protege); c) desacordos sobre quais normas são relevantes para se considerar em determinado caso; d) divergências acerca do peso ou importância de cada norma num determinado caso concreto; e) divergências sobre especificações apropriadas; f) conflitos sobre a própria forma de sopesamento das normas e valores em questão; g) a ocorrência ou não de um genuíno problema moral; h) insuficiência de informação ${ }^{268}$.

Pode haver, portanto, acordo entre os interlocutores de um debate moral sobre a importância de determinado bem ou preceito para a sociedade, como a necessidade de preservação da vida humana. Ocorre que muitas vezes, como acontece no caso do aborto, a divergência paira sobre a própria interpretação de determinado termo ou preceito.

De fato: qual vida deve ser preservada, num conflito entre a vida fetal e a da mãe, que decide interromper a gravidez? O feto é considerado pessoa? O que deve ser entendido por pessoa? Daí vem a complexidade das discussões bioéticas. Os desacordos embasam-se em níveis vários, não sendo possível esquematizar, mesmo no caso de concordância sobre a prevalência de um bem a ser preservado, a interpretação que se deva dar ao caso discutido.

Também é necessário discorrer acerca de algumas teorias que entendem mais apropriada a visão relativista dos valores morais, refutando, consequentemente, a existência de verdades morais incontrastáveis, válidas de modo absoluto ou universal.

Não temos a pretensão de esgotar os argumentos trazidos pela corrente relativista nem foi este o escopo das considerações acerca do universalismo axiológico. Contudo interessa esboçar, ainda que sinteticamente, alguns dos principais argumentos e pensamentos encontrados entre os juristas e filósofos morais.

De início, como destacado por Gilbert Harman, não há que se confundir as teses sobre o relativismo moral com o denominado niilismo moral. A formulação central do

${ }^{268}$ BEAUCHAMP, Tom L.; CHILDRESS, James F. Principles of biomedical ethics. Oxford University Press: Oxford, 2001, pp. 21-22. Como destacado pelos autores, "duas culturas ou indivíduos podem concordar sobre um princípio fundamental de moralidade, embora discordem sobre a interpretação a este princípio a ser dada ou como aplicá-lo numa situação específica" (tradução nossa). No original: "Two cultures or individuals may agree about fundamental principle of morality, yet disagree about how to interpret or apply that principle in a particular situation". 
relativismo pode ser escrita da seguinte forma: não há uma moralidade verdadeira. Há muitos padrões morais, nenhum deles mais correto que os outros. Para os adeptos do niilismo moral, de fato não há que se falar em uma moral mais verdadeira que outra, como propugnado pelo relativismo. No entanto, partindo desta premissa, o niilista adota uma postura de desengajamento para qualquer debate moral, como se não houvesse sentido, a partir daí, na formulação de juízos morais - o que não se coaduna com o pensamento relativista $^{269}$.

Deveras, para o relativismo axiológico, a moralidade não deve ser abandonada. $\mathrm{O}$ que ocorre é a não formulação de uma moralidade a ser seguida como correta e inabalável. Não se justificariam, portanto, o abandono dos debates éticos e o estabelecimento de pontos de vista morais. A diversidade não pode implicar, como muitos pensam, o absenteísmo como sujeito moral, em um diálogo estabelecido num determinado discurso. Não se trata, pois, de embasar-se na premissa de que "se tudo vale, para que discutir?"

Pode-se dizer que as diferenças existem em dois ou mais níveis dos estratos sociais. Por exemplo, as divergências não existem somente entre sociedades diferentes, mas também dentro da mesma sociedade ${ }^{270}$.

Ora, os partidos políticos, por exemplo, reúnem-se em torno de ideais que podem ser contrapostos, as manifestações artísticas revelam infindáveis modos de sentir e exteriorizam particularidades irrepetíveis, as diversas faixas etárias que compõem a sociedade buscam realizar-se de acordo com as peculiaridades de desenvolvimento e as necessidades que possuem.

Enfim, uma infinidade de diferenças entrecruza-se e constrói um tecido social com estampas várias. Tudo isso dentro de um grupo, que certamente, mesmo considerando algumas características próprias de identidade de um povo, se diferenciará de tantos outros pelo mundo, numa complexidade indescritível e irreproduzível através das épocas.

Pode-se dizer, ademais, que as avaliações relativistas são efetuadas com base em um parâmetro de avaliação, perante o qual determinada conduta ou ação é julgada como errada ou correta.

\footnotetext{
${ }^{269}$ HARMAN, Gilbert. THOMSON, Judith Jarvis. Moral relativism and moral objectivity. Oxford: Blackwell, 2003, pp.5-6.

${ }^{270}$ Ibid., p. 10. "Uma das coisas mais importantes a explicar sobre a diversidade moral é que ela ocorre não apenas entre sociedades, mas dentro de sociedades e de modo a conduzir a intratáveis desacordos morais" (tradução nossa). No original: "One of the most important things to explain about moral diversity is that it occurs not just between societies but also within societies and in a way that leads to seemingly intractable moral disagreements".
} 
O julgamento é relativo a algo, que pode ser diferente em outros lugares. Um determinado ato, por exemplo, pode ser considerado um crime perante a legislação de determinado país, mas não perante o ordenamento jurídico de outro. Do mesmo modo, uma conduta pode ser censurada com relação aos valores cultivados por um indivíduo, mas promovida por outros. Assim, é impróprio pensar em condutas boas por si mesmas ou más em absoluto: sempre há uma avaliação por parâmetros. Nesse sentido, tem-se o que Gilbert Harman denomina de um sistema moral de coordenadas, o que se conecta, por conseguinte, ao que é bom ou mau para determinada pessoa (good for), moral ou imoral. É o caso do aborto, que para alguns pode ser praticado, enquanto para outros representa uma conduta grave e ruim ${ }^{271}$.

Outro ponto de análise da diversidade moral diz respeito aos desacordos que têm origem afetiva, sendo complexo chegar a uma solução que ponha fim às diferenças. Assim, se a razão é concebida como ferramenta capaz de resolver as disputas morais, há uma limitação na própria afetividade humana, que escapa, muitas vezes, dos preceitos racionais. Dessa maneira, para ilustrar, seria complicado convencer alguém que goste de determinada cor a gostar e preferir outra cor. $\mathrm{E}$, nesses casos, a diferença não significa uma contradição ${ }^{272}$.

Os filmes são um exemplo vívido de que alguns conflitos axiológicos que se instauram entre os homens são apreendidos através dos elementos pático e afetivo. Assim, as teorias da Filosofia do Direito encontram sua morada e vida em muitas películas, evidenciando-se as discussões por meio da linguagem visual. Há, enfim, um diálogo afetivo e efetivo.

Também Kelsen propugna em sua Teoria Pura do Direito pelo relativismo axiológico. Especialmente no livro A Justiça e o Direito Natural encontra-se uma análise crítica sobre o imperativo categórico kantiano, que se estrutura na seguinte maneira: Age sempre de tal modo que a máxima do teu agir possa por ti ser desejada como lei universal. Ora, esclarece Kelsen, "se nós podemos querer que aquilo que nós propomos a nós

\footnotetext{
${ }^{271}$ Ibid., pp. 13-15. "Uma resposta relativista é também plausível no caso moral. O certo e o errado em termos morais são questões relativas. Um determinado ato pode ser correto em relação a um sistema moral de coordenadas e errado em relação a outro sistema moral de coordenadas. E nada é absolutamente certo ou errado fora de qualquer sistema de coordenadas morais" (tradução nossa). No original: "A relativistic answer is also plausible in the moral case. Moral right and wrong are relative matters. A given act can be right with respect to one system of moral coordinates and wrong with respect to another system of moral coordinates. And nothing is absolutely right and wrong, apart from any system of moral coordinates".

${ }^{272}$ Ibid., p. 21.
} 
próprios como regra do nosso agir se transforme numa lei universal, então o imperativo categórico não conduziria necessariamente a uma actuação moralmente boa"273.

Kelsen analisa, em seguida, as restrições consideradas por Kant, que explicita não ser possível que todas as máximas que alguém se ponha como lei tornem-se leis universais, criticando cada uma delas.

Mas não é só. Como salienta Kelsen,

patente que com o 'poder querer' do imperativo categórico, se quer significar um 'dever querer', que o verdadeiro sentido do imperativo categórico é: Actua segundo uma máxima da qual devas querer que ela se transforme numa lei universal. Mas, de que máxima devo eu querer e de que máxima devo eu não querer que ela se transforme numa lei universal? A esta questão não dá o imperativo categórico qualquer resposta (...) o que ele exige nada mais é que a conformidade da acção a uma lei, isto é, a sua harmonização com uma norma geral $^{274}$.

Dessa maneira, toda ação poderia se conformar a uma lei geral, o que tornaria o imperativo categórico uma fórmula vazia de conteúdo, com lastro em falsas ilações.

Enfim, pode-se afirmar que

a única coisa que é possível é verificar se uma lei moral concreta pressuposta como válida é compatível com o imperativo categórico, pois este nada mais exige senão que a máxima da acção seja conforme a uma lei universal, já que nada mais se afirma das leis morais senão que elas hão-de ter o caráter de normas gerais $^{275}$.

A estruturação de um pensamento sobre uma moral relativa é coerente com as reflexões sobre o positivismo jurídico que permeiam a obra de Kelsen, especialmente considerando que a fundamentação do Direito não se encontra em uma autoridade metafísica, transcendental, ou mesmo na natureza.

Ao contrário, numa ordenação escalonada em que uma norma haure seu fundamento de validade em outra norma, a questão do conteúdo deixa de ter importância, de maneira que tudo pode ser conteúdo em uma ordem jurídica positiva, tal como

${ }^{273}$ KELSEN, Hans. A justiça e o direito natural. Coimbra : Armenio Amado, 1963, p. 26. Também no livro O Problema da Justiça de Kelsen, é reproduzida a discussão atinente ao imperativo categórico.

${ }^{274}$ Ibid., p. 31.

${ }^{275}$ Ibid., p. 33. 
concebido pelo autor. Assim, a questão da justiça ou injustiça poderia ser aventada em outros temas, como a seara eficacial, que não é, entretanto, fundamento de validade de uma norma.

No que concerne ao conteúdo, colhe-se da obra do autor que

todo e qualquer conteúdo pode ser Direito. Não há qualquer conduta humana que, como tal, por força do seu conteúdo, esteja excluída de ser conteúdo de uma norma jurídica. A validade desta não pode ser negada pelo fato de seu conteúdo contrariar o de uma outra norma que não pertença à ordem jurídica cuja norma fundamental é o fundamento de validade da norma em questão ${ }^{276}$.

Nisto encontramos uma pista sobre o posicionamento do autor acerca da possibilidade de uma moral que deva ser referência para um dado sistema jurídico posto. Não existe tal moral.

Melhor dizendo, determinado conteúdo irrelevante em uma norma jurídica, que poderá ser considerada válida mesmo se contrariar as normas ditadas por determinada norma moral que se espraie pelo corpo social.

Ora, caso a validade de uma norma fosse condicionada à conformidade com certa norma de outro sistema normativo, estaríamos a admitir como direito somente um direito justo, sendo tudo aquilo que contraria os mandamentos morais um direito injusto e, portanto, um não direito. Essa noção é completamente afastada pelo autor da Teoria Pura do Direito, que não vincula validade do direito à conformidade com uma ordem moral.

A postura relativista extrai-se da análise dessas ideias. Deveras, admitir como direito válido somente aquele que se coaduna com determinados padrões de justiça seria dizer que existe uma moral absoluta, ou seja, $a$ Moral perante a qual se curva o direito posto.

Dessa forma, segundo o autor,

não se aceita de modo algum a teoria de que o Direito, por essência, representa um mínimo moral, que uma ordem coercitiva, para poder ser considerada como Direito, tem de satisfazer uma exigência moral mínima. Com esta exigência, na

\footnotetext{
${ }^{276}$ KELSEN, Hans. Teoria Pura do Direito. São Paulo: Saraiva, 2009, p. 221. Ver também: HART, Herbert L. A. O conceito de Direito. Lisboa: Fundação Lacouste Gulbenkian, 2007, p. 215. Hart, ao estipular as regras que constituem um conteúdo mínimo da sociedade, acaba por relativizar a ideia de que o Direito possa ter qualquer conteúdo, pois alude a "formas mínimas de proteção das pessoas, da propriedade e dos compromissos". Como escreve, "é desta forma que devemos responder à tese positivista de que "o direito pode ter qualquer conteúdo"”.
} 
verdade, pressupõe-se uma Moral absoluta, determinada quanto ao conteúdo, ou, então, um conteúdo comum a todos os sistemas de Moral positiva ${ }^{277}$.

Para complementar a rejeição de um sistema de Direito positivo que se vincule aos ditames de uma Moral absoluta, o autor rebate as críticas feitas ao relativismo axiológico.

Como escreve Kelsen,

$$
\begin{aligned}
& \text { uma teoria dos valores relativista não significa }- \text { como muitas vezes } \\
& \text { erroneamente se entende - que não haja qualquer valor e, especialmente, que } \\
& \text { não haja qualquer Justiça. Significa, sim, que não há valores absolutos mas } \\
& \text { apenas valores relativos, que não existe uma Justiça absoluta mas apenas uma } \\
& \text { Justiça relativa, que os valores que nós constituímos através dos nossos atos } \\
& \text { produtores de normas e pomos na base dos nossos juízos de valor não podem } \\
& \text { apresentar-se com pretensão de excluir a possibilidade de valores opostos }{ }^{278} \text {. }
\end{aligned}
$$

Assim, verifica-se que a tese relativista, num debate bioético, não representa, de modo algum, o abandono de considerações acerca da justiça. Ocorre que se afasta das ponderações que veem sentido em apenas uma justiça possível.

Daí a utilização do termo Bioéticas, que revela uma pretensão não totalizante, de abertura às mais diversas visões, num diálogo que não se esgota, mas que pode, sim, chegar a uma acordo sobre o tema debatido - que não será eterno, mas para o parâmetro do caso concreto. Ou seja, a diversidade moral dialética não afasta a possibilidade de decisão, mas transfere-a para um contexto que considera os sujeitos envolvidos no problema, ponderando-se todos os pontos de vista apresentados, sem que qualquer deles mostre-se, de antemão, como determinante, absoluto e irretocável.

Tudo é provisório. Isto quer dizer, a complexidade dos temas não se coaduna com uma resposta fechada e final. Esta a essência do relativismo. Assim como o próprio homem muda, as necessidades são outras a cada instante, e nem mesmo a razão dá conta de uma lei moral universal.

Na lição de Nietzsche,

a questão de quanto vale esta ou aquela tábua de valores, esta ou aquela "moral", pode ser examinada sob os pontos de vista mais diversos e que principalmente não se pode expor de um modo suficientemente sutil "este" valor para uma coisa que teria grande valor para a conservação de uma raça e

\footnotetext{
${ }^{277}$ KELSEN, Hans. Teoria Pura do Direito. São Paulo: Saraiva, 2009, p. 74.

${ }^{278}$ Ibid., p. 76.
} 
aumento de suas forças de assimilação num clima determinado ou para manutenção de maior número, não teria de forma alguma o mesmo valor se se tratasse de criar um tipo superior. O bem da maioria e o bem da minoria são dois pontos de vista completamente opostos: deixaremos à ingenuidade dos biólogos ingleses a liberdade de considerar o primeiro como superior em si mesmo... Todas as ciências devem preparar ao filósofo a sua tarefa, que consiste em resolver o problema dos valores, em determinar a hierarquia dos valores $^{279}$.

Neste passo, sentidos absolutistas perdem vigor nessa seara dialética que contorna a Bioética e, consequentemente, as discussões envolvendo a interrupção da gravidez. No entanto, é comum verificar argumentos que entendem a vida humana em sentido absoluto, um valor universal a ser respeitado, pois é pressuposto lógico da pessoa.

Para ilustrar todo o plexo teórico abordado neste capítulo, entendemos pertinente ilustrar com as análises dos filmes $O$ segredo de Vera Drake, e 4 meses, 3 semanas e 2 dias, o que dará sentido a todas essas discussões sobre valores e moralidade.

\subsection{Análise do filme $O$ segredo de Vera Drake}

De início, é necessário destacar que o filme examinado faz parte do programa elaborado pela Professora Orientadora, sendo trabalhado nas turmas de graduação na disciplina Introdução ao Estudo do Direito. Além disso, foi um dos filmes indicados no curso de Pós-Graduação da Faculdade de Direito da Universidade de São Paulo, elaborado pela Professora Mara Regina de Oliveira, intitulado "Cinema e Filosofia do Direito: o problema da verdade e da justiça no exercício jurídico do poder", ministrado no primeiro semestre de $2010^{280}$.

Conforme apontado na seção anterior, para análise de outros desdobramentos referentes ao aborto, tomamos o filme $O$ segredo de Vera Drake, que também é expressivo ao tratar da prática abortiva com evidente destaque à clandestinidade e à tensão existencial que se projeta. Se é verdade que o filme não reproduz a realidade, possuindo tão-somente

\footnotetext{
${ }^{279}$ NIETZSCHE, Friedrich. A genealogia da Moral. Petrópolis: Vozes, 2009, p. 56.

${ }^{280}$ Foi escrito, em coautoria com a Professora Orientadora o artigo "O aborto clandestino como rejeição da autoridade e a questão do relativismo axiológico: uma análise comparativa dos filmes $O$ segredo de Vera Drake e 4 meses, 3 semanas e 2 dias". No prelo. Vale mencionar que as falas destacadas foram retiradas do filme.
} 
uma impressão de movimento e de verdade ${ }^{281}$, não é possível desconsiderar a inspiração no real, ao retratar dilemas que se imbricam à própria condição humana. Mais do que isso, a experiência do cinema permite uma aproximação com um problema humano que articula o racional e o emocional, afetivo, instaurando uma forma de racionalidade logopática ${ }^{282}$.

Tomaremos como base para nossa análise a teoria pragmático-jurídica da comunicação, assentada sobre o princípio da interação: os sujeitos de um discurso emitem e recebem mensagens, construindo uma relação.

A narrativa de $O$ segredo de Vera Drake explora, como um dos temas centrais, a delimitação entre as esferas do Direito e da Moral e, ainda, o relativismo axiológico. A obra de Mike Leigh é fecunda na abordagem de um tema intrincado e polêmico, expondo a angústia de algumas das personagens na intensidade mais aguda, evidenciando algumas temáticas humanas recorrentes na Filosofia Moral.

Mesmo que a abordagem do filme refira-se também à clandestinidade, como o faz o crime de Cristian Mungiu (4 meses, 3 semanas e 2 dias), que analisaremos em seguida, o enfoque é ligeiramente diverso, conforme se verá.

A separação entre moralidade e legalidade ${ }^{283}$, entre o justo por natureza e o justo por convenção, torna-se patente com os distintos julgamentos existentes. Um é oficial, baseado na legalidade, no direito vigente na época; outro conecta-se ao senso de justiça, e pode equivaler ao comando da lei - porém, não é algo inexorável, como veremos. O primeiro, fundamenta-se nas leis postas, convencionadas, na Seção 58 da "Lei contra as Pessoas" de 1861; o julgamento segundo os ditames da moralidade é feito pelos outros personagens, consoante seu próprio entendimento de justiça, o que é extremamente variado.

O enredo tem lugar na Inglaterra da década de 1950, e centra-se na história de Vera, uma senhora que se dedica aos trabalhos domésticos em algumas residências para ajudar a família: o marido (Frank) que trabalha numa oficina e seus dois filhos, Sid e Ethel. A casa é simples e, no entanto, receptiva, especialmente considerando-se a esperança de se

\footnotetext{
${ }^{281}$ BERNADET, Jean-Claude. O que é cinema. São Paulo: Editora brasiliense, 2006, p. 12. "Essa ilusão de verdade, que se chama impressão de realidade, foi provavelmente a base do grande sucesso do cinema".

${ }^{282}$ CABRERA, Julio. O cinema pensa: uma introdução à Filosofia através dos filmes. Rio de Janeiro: Rocco, 2006, p. 21.

${ }^{283}$ REALE, Miguel. Filosofia do Direito. São Paulo: Saraiva, 1982, p.618. "Segundo Ihering, a relação entre a Moral e o Direito constituiria o Cabo Horn ou o Cabo das Tormentas da Filosofia do Direito, tão eriçada é de dificuldades. Já mais pessimista, Benedetto Croce chegou a ponto de dizer que se trata propriamente do Cabo dos Náufragos, porquanto teriam falhado todas as doutrinas tendentes a delimitar os dois campos".
} 
arrumar um namorado à filha, Ethel, extremamente tímida, que trabalha testando lâmpadas incandescentes.

Entre a vida de esposa, mãe e doméstica, Vera ajuda outras pessoas, mulheres - o que faz sem receber nada em troca. A intenção é de propiciar alívio, acalmar e possibilitar que as mulheres continuem suas vidas normalmente: Vera induz abortos. Faz-se relevante, pois, a noção dos núcleos significativos, que no caso podem ser depreendidos dos papéis sociais que cada um desempenha (pai/marido, filho, mãe/esposa/ "aborteira" etc).

Entre os mecanismos de estabilização (núcleos significativos), destaca-se a pessoa. Trataremos dos desdobramentos do conceito de pessoa no capítulo quinto, ocasião em que dedicaremos tópico específico ao estudo da noção de núcleos significativos.

As sequências e cortes revelam que a prática abortiva em mulheres data de muito tempo - tanto que Vera não sabe precisar desde quando ajuda outras mulheres grávidas mas reconhece que o faz de longa data. E são duas as formas que possibilitam contato entre Vera e as pessoas que ajuda: algumas moças e mulheres, ela já conhece; outras são indicadas por Lilly, que serve como mediadora e que, na trama, é a personagem que lucra com os abortos, pois cobra caro de mulheres que necessitam realizar o procedimento interruptivo da gravidez.

Poderíamos aventar, na atitude de Vera Drake, um sentido de justiça que se aproxima da caritas, justiça como amor, que por seu turno liga-se ao amor cristão. Ainda que não deliberadamente, sua maneira de atuação, ao interromper as gravidezes como forma de ajuda, acaba por manter íntegro o modelo de família cristã dominante na época, que não se compadeceria com frutos advindos de traições, ou com muito pesar aceitaria um filho sem pai. Na lição de Tércio Sampaio Ferraz Jr.,

o amor-caritas tem o sentido de renúncia, mas de uma renúncia que não é privação, mas plenitude. $\mathrm{O}$ amor cristão não tem, assim, uma compensação no amor do outro, mas na plenitude do amor divino. E a plenitude do amor divino explica que um Deus onipotente ofereça o sacrifício de seu filho pela salvação dos homens ${ }^{284}$.

${ }^{284}$ FERRAZ Jr., Tércio Sampaio. Justiça como retribuição: da razão e da emoção na construção do conceito de justiça. In: Estudos de Filosofia do Direito: reflexões sobre o poder, a liberdade, a justiça e o Direito. São Paulo: Atlas, 2009, p.240. Vale ressaltar que essas conclusões foram tomadas após conversa com a Professora Orientadora. 
Nota-se que Lilly consegue circular em estratos sociais mais abastados. Com o que recebe, vive e compra alguns mantimentos para revender à própria Vera, nas ocasiões em que a encontra para indicar o endereço da pessoa que se submeterá ao aborto. Premedita seus atos sem qualquer escrúpulo, a começar pelo simples fato de não escrever, a próprio punho, o endereço das mulheres, que grafam, com sua letra, o local de sua residência.

Vera acaba sendo um verdadeiro instrumento para os ganhos de Lilly, que praticamente reduz a relação entre ambas aos interesses egoísticos. Nota-se, nesse ponto, a reificação, mero meio para os fins de Lilly, contrapondo-se frontalmente à máxima kantiana. Como escreve o filósofo,

o homem, e, duma maneira geral, todo o ser racional, existe como fim em si mesmo, não apenas como meio para o uso arbitrário desta ou daquela vontade. Pelo contrário, em todas as suas acções, tanto nas que se dirigem a ele mesmo como nas que se dirigem // a outros seres racionais, ele tem sempre de ser considerado simultaneamente como fim. Todos os objectos das inclinações têm somente um valor condicional, pois, se não existissem as inclinações e as necessidades que nelas se baseiam, o seu objecto seria sem valor. As próprias inclinações, porém, como fontes das necessidades, estão tão longe de ter um valor absoluto que as torne desejáveis em si mesmas, que, muito pelo contrário, o desejo universal de todos os seres racionais deve ser o de se libertar totalmente delas. Portanto o valor de todos os objectos que possamos adquirir pelas nossas acções é sempre condicional. Os seres, cuja existência depende, não em verdade da nossa vontade, mas na natureza, têm contudo, se são seres irracionais, apenas um valor relativo, como meios e por isso se coisas, ao passo que os seres racionais se chamam pessoas, porque a sua natureza os distingue já como fins em si mesmos, quer dizer como algo que não pode ser empregado como simples meio e que, por conseguinte, limita nessa medida todo o arbítrio (e é um objecto do respeito) $^{285}$.

Os apetrechos utilizados por Vera não são engenhos complexos: em geral, utiliza uma bacia com água morna, dentro da qual dilui detergente/sabão, utilizando uma bomba de plástico para promover a entrada da água dentro do útero das grávidas. Assim, não usa na sua empreitada instrumentos cortantes, metálicos, o que é destacado ao final.

\footnotetext{
${ }^{285}$ KANT, Immanuel. Fundamentação da Metafísica dos costumes. Lisboa: Edições 70, 2008, pp.71-72.
} 
Comumente, quem realiza o aborto clandestino não dispõe de meios sofisticados para interrupção da gravidez. Pelo contrário, a precariedade é um traço que se faz presente, como verificaremos também, em seguida, na análise de 4 meses, 3 semanas e 2 dias.

$\mathrm{Na}$ casa de Vera, a euforia com o noivado da filha - Ethel - contagia todos os membros da família, que já estavam desesperançosos com o casamento da moça. A notícia chega aos parentes mais próximos e se prepara uma comemoração para o que consideram um verdadeiro evento.

Entremeio toda essa felicidade de construção de uma família, a interrupção da gravidez apresenta-se em $O$ segredo de Vera Drake como a solução para alguns problemas vivenciados por certas mulheres. Podemos destacar, pois, algumas das razões pelas quais o aborto é praticado: a) estupro, como no caso de Susan, em que a gravidez é resultante de relação sexual forçada; b) ocultação de relações extraconjugais que resultariam em gestação; c) controle populacional, como no caso da senhora que já tinha vários filhos, sendo impossível à família arcar com todos os custos relacionados à chegada de mais um membro; e d) despreparo ou imaturidade (gestante adolescente, com todo um futuro adiante).

Alguns desses casos são retratados no documentário $O$ aborto dos outros, destacando-se o enfoque médico e de saúde pública. A análise dessa película será feita no último capítulo.

Em $O$ segredo de Vera Drake, o aborto no caso de estupro ocorre com a personagem Susan, filha dos patrões de Vera. A moça é forçada ao intercurso sexual numa noite em que fica sozinha com o namorado.

A violência é destacada nas cenas em que a repulsa de Susan torna-se o recorte do início da violência psicológica, pelo fato de não estar preparada para ser mãe. Pede conselhos a uma amiga, mas a sua problematização é feita como se quem precisasse de ajuda fosse outra pessoa.

Então, Susan consulta alguns médicos psiquiatras, decidida a pôr termo ao sofrimento e interromper a gravidez, pois prefere se matar a ter o bebê, mas descobre que nos altos estratos sociais, quem pode pagar por um serviço médico - ainda que não faça parte das especialidades médicas -, paga muito caro (cerca de 150 libras).

Os cortes e cenas envolvendo Susan destacam que o aborto não era restrito aos denominados aborteiros: médicos renomados que atendiam a elite também o praticavam, mas sem que isso descaracterize a nota de clandestinidade. $\mathrm{O}$ fato é que as condições de sua prática, como os recursos disponíveis para o pós-aborto, eram muito melhores para 
quem tinha dinheiro e podia arcar com os custos do procedimento abortivo, o que implicava menores riscos de complicações, muito maiores quando praticados fora de uma enfermaria, na cama de uma residência simples. A ética médica é condicionada e subsiste dependendo da disposição em desembolsar a quantia pleiteada pelo profissional.

Para controle de natalidade, o aborto é praticado em Nora, personagem que já tem sete filhos, já que o marido não consegue se controlar, conforme é apresentado no filme. Os escassos métodos anticoncepcionais não alcançam as famílias, especialmente as mais pobres, que recorrem ao abortamento.

O curioso é que há uma ocultação da prática aos próprios maridos, que "não poderiam saber". Esta ideia remete-nos a algumas considerações sobre o direito à vida intrauterina, cujo poder de disposição foi por muito tempo do paterfamiliae. Assim, a vida e a morte do feto ficavam sob o jugo dos homens em várias sociedades, o que se verifica também em algumas tribos indígenas, em que as mulheres, para se vingar dos maridos, abortavam, significando isto uma ofensa direta. Como destaca Celso Cezar Papaleo,

interessante, a propósito, lembrar que Anchieta, em contato evangelizador com os nossos aborígenes, verificava a prática, entre as mulheres, da provocação do aborto, que ocorreria 'muitas vezes mais por humana malícia que por desastre'. Acrescentava que por motivos diversos as índias chegavam a tanto: 'iradas contra seus maridos', ou por medo, 'ou contra qualquer ocasião mui leviana matam os filhos, 286 .

Temos, ainda, a interrupção da gravidez como modo de ocultação de relações extraconjugais, no caso de mulheres casadas que se meteram em encrencas. Fato que significaria desonra ou ruína da família encontra desembaraço nas mãos de Vera.

Por fim, destaca-se o abortamento no caso de moças muito jovens - praticamente meninas - despreparadas para assumirem o papel social de ser mãe ${ }^{287}$. É a situação de Pamela Barnes, cuja interrupção da gravidez desencadeia uma das questões centrais do filme, podendo ser considerada um marco na vida de Vera Drake.

\footnotetext{
${ }^{286}$ PAPALEI, Celso Cezar. Aborto e contracepção: atualidade e complexidade da questão. Rio de Janeiro: Renovar, 2000, p. 20.

${ }^{287}$ BRUNO, Zenilda Vieira. Abortamento na adolescência. In: CAVALCANTE, Alcilene; XAVIER, Dulce (org). Em defesa da vida: aborto e direitos humanos. São Paulo: Católicas pelo Direito de Decidir, 2006, p.82. Escreve a autora que "o principal risco da gravidez na adolescência não é de natureza biológica ou médica, é de natureza psicossocial.
} 
Os abortos realizados pela personagem são procedimentos que se desenrolam com o apoio emocional de Vera (Não fique tão chateada/Só vim te ajudar). E, como atividade que desenvolve há anos, nota-se tranquilidade e serenidade ao expor os acontecimentos que sucederão a sua visita: amanhã ou depois sentirá uma dor embaixo/ vá ao banheiro e começará a sangrar, então irá embora/ Tudo passará querida, ficará novinha em folha. Frases que se repetem nas inúmeras visitas que faz (o filme mostra no mínimo cinco abortos). A habitualidade com que Vera ajuda no abortamento fica clara ao ser indagada sobre o que fez nas casas que visitou. Diz: o mesmo de sempre/dei conselhos.

Em certa ocasião, Vera vai à casa de Mrs. Barnes, para interromper a gestação da filha Pamela Barnes. Lilly é quem intermediou o contato entre Vera e a mãe de Pamela, cobrando por isto 20 libras. O procedimento é repetido tal qual as outras inúmeras vezes, utilizando a água com detergente e a bombinha. No entanto, dessa vez ocorrem complicações e Pamela cai doente, quase morre. É levada ao hospital após a visita do médico, que questiona Mrs. Barnes: A senhora fez algo para que isso ocorresse? E a fala seguinte demonstra que o aborto, também naquela época, não era algo extremamente excepcional: Sou médico há 25 anos/vemos isso todas as semanas, não vemos? (e olha para a enfermeira que o acompanhava). O fato - interrupção da gravidez - era, pois, de conhecimento dos médicos - alguns, inclusive, o praticavam.

Nessa ocasião, o médico insiste para que lhe seja dito o nome da pessoa que praticara, mas a mãe de Pamela reluta, mantendo o tempo que pode o segredo. Mas o doutor a pressiona: Esta pessoa deve ser impedida. E dispara que, se a mãe não fosse espontaneamente à polícia, ele iria, dizendo duas frases: infelizmente, é minha obrigação moral e logo em seguida diz, percebe que é um crime? Para o médico, nesse caso, as esferas da Moral de do Direito se justapõem. Há também uma equivalência entre a obrigação moral e não praticar um crime de aborto.

Para Vera, a razão que ensejava a procura pelo aborto não importava. Seu contentamento advinha da possibilidade de tornar a vida de outra pessoa melhor, eis que sobreleva um conceito-imagem de alteridade, na preocupação com os outros. É o que podemos ver já no início do filme, quando Vera ajuda um senhor deficiente físico, bem como nas referências feitas a ela como mulher que possui um coração de ouro. E sua satisfação é sua maior recompensa - apesar de, em ocasião posterior, ser chamada de egoísta por Joyce, sua cunhada, quando esta descobre o segredo de Vera.

E é também seu segredo. O que Vera oculta - da família e de pessoas que nunca admitiriam - é justamente as práticas abortivas. Como a chave da casa que esconde 
debaixo do tapete, e que vem à tona quando precisa auxiliar o morador com necessidades especiais. É um de seus ofícios: tão importante como a limpeza de outras residências, é a limpeza da alma das pessoas que auxilia. E para ser um segredo, é algo que não pode ser dito.

É também uma maneira de Vera poupar sua família, pois compreende que o que faz não é bem aceito pela sociedade da época - tanto que configura um crime, cuja designação é absolutamente rejeitada por Vera Drake, que prefere afastar esta terminologia e a caracterização que o Estado dá à sua conduta (crime). Mas, mesmo assim, Vera sabe que lida com esferas diferentes, a da Moral e a do Direito, daí as avaliações tão distintas. E, mesmo na esfera Moral, exsurgem inúmeros julgamentos acerca da moralidade da conduta, conforme destacaremos mais à frente.

O segredo ${ }^{288}$ de Vera é algo que se esconde, mas também algo que escondem, sendo um sigilo das mulheres que abortam. O segredo não é só de Vera: é das esposas que não podem dizer ao marido, é de Mrs. Barnes, que se constrange e reluta em contar ao médico quem induziu ao aborto.

Eis o traço que contorna a clandestinidade das práticas abortivas, tanto por quem pratica como em quem são praticadas: há o silêncio reverberante. Oportuno lembrar que

o poder do silêncio sempre foi muito estimado. Ele significa que uma pessoa é capaz de resistir a todas as inumeráveis oportunidades que se lhe oferecem para falar. Uma tal pessoa não dá resposta alguma, como se jamais lhe houvessem feito qualquer pergunta. Não dá a perceber se gosta disto ou daquilo. É muda sem se calar. Mas ouve. Em seu extremo, a virtude estóica da imperturbabilidade haveria de conduzir necessariamente ao silêncio ${ }^{289}$.

O segredo não significa mentira, mas certa omissão. Sid atribui à mãe um etiquetamento: mentirosa. O marido, ao contrário, compreende tudo como mera omissão. De fato, é evidente a intenção de Vera em esconder para poupar os familiares; o fim almejado com seu silêncio era nobre.

Após a comunicação às autoridades, os policiais dirigem-se à casa de Vera, que está reunida com a família para comemoração do noivado de Ethel, ocasião em que também é

\footnotetext{
${ }^{288}$ Vale lembrar que, no original, não há a palavra "segredo". O título do filme em inglês restringiu-se ao nome de Vera Drake.

${ }^{289}$ CANNETI, Elias. Massa e poder. São Paulo: Companhia das Letras, 1995, p. 294.
} 
anunciada a gravidez de Joyce, sua cunhada; todos celebram a notícia, inclusive Vera, que manifesta um contentamento autêntico.

A alegria, entretanto, dura pouco. A polícia chega e, ao entrar na casa, o close-up $p^{290}$ desmonta toda felicidade que se estampava no rosto de Vera - que sabia o motivo da visita. Seu rosto apaga-se, emergindo uma tensão que se irradia na família, estranhados com tudo aquilo. Acreditam que tudo não passará de um equívoco, afinal, não suspeitam que possa existir, de fato, qualquer fato desabonador, desonesto ou criminoso.

Quando os policiais chegam até sua casa e chamam-na para conversar num local mais reservado, vão para o quarto de Vera. Lá, ela diz que sabe por que vieram: pelo que fiz/ajudo jovens. Quando é indagada sobre como as ajuda, Vera responde: quando não podem resolver/ajudo a menstruarem novamente. E segue o diálogo entre policiais $(\mathrm{P}) \mathrm{e}$ Vera (V): P: Ajuda a livrarem-se do bebê/V: Não é isso que façolé como o chama, mas elas precisam de ajuda/ pedem ajuda, não querem dar, e eu as ajudo.

Como escreve Elias Canetti,

toda pergunta é uma intromissão. Onde ela é aplicada como um instrumento de poder, a pergunta corta feito faca a carne do interrogado. Sabe-se de antemão o que se pode descobrir, mas quer-se descobri-lo e tocá-lo de fato. Com a segurança de um cirurgião, o inquiridor precipita-se sobre os órgãos do interrogado. Esse cirurgião mantém viva a sua vítima para saber mais sobre ela. É uma espécie particular de cirurgião, que atua provocando deliberadamente a dor em certos pontos; estimula certas porções da vítima para saber de outras com maior segurança ${ }^{291}$.

O "ilícito" que Vera pratica não se insere, para ela, nos domínios da imoralidade, tanto que chora ao saber da gravidade da situação de Pamela Barnes.

Após a sua prisão - e ela não resiste um momento sequer, para não arruinar o resto da noite de seus familiares -, Vera pede segredo sobre o que fez. Pega sua caixa, com todos os instrumentos que utilizava para ajudar outras mulheres e abre sobre a cama. É como se fossem apreendidos os instrumentos, as armas de um crime. Na delegacia, entrega seus pertences, mas lhe é difícil entregar a aliança, após 27 anos de casada. Nessas cenas,

\footnotetext{
${ }^{290}$ BALACS, Bela. Nós estamos no filme. In: XAVIER, Ismail (org). A experiência cinematográfica. Rio de Janeiro: Edições Gerais Graal, Embrafilmes, p. 91. "Close-ups são as imagens que expressam a sensibilidade poética do diretor. Mostram as faces das coisas e também as expressões que, nelas, são significantes porque são reflexos de expressões de nosso próprio sentimento subconsciente. Aqui se encontra a arte do verdadeiro operador de câmera".

${ }^{291}$ CANNETI, Elias. Massa e poder. São Paulo: Companhia das Letras, 1995, p. 285.
} 
pela simbologia das sutilezas, percebe-se o quanto a família era importante para Vera, como na decisão de poupá-los da verdade, na comemoração do noivado de Ethel e da gravidez de Joyce.

O interrogatório estende-se na delegacia e quando lhe perguntam quanto cobra, Vera assusta-se: não aceito dinheiro, nunca aceitei/ Não é por dinheiro. Então lhe revelam que Lilly cobrava. Ao final, é formalmente acusada pelo aborto praticado em Pamela Mary Barnes, de acordo com a Seção 58 da "Lei contra as Pessoas" de 1861.

A família, enfim, toma conhecimento do que permaneceu oculto por muitos anos. Primeiro, o marido; depois, os filhos e cunhados. Seguem os diálogos que representam a avaliação da conduta de Vera pela sua família. A reflexibilidade do discurso pode ser verificada pelo movimento de intercâmbio nas posições ocupadas por emissores e receptores.

Entre pai (Pa) e filho (F), a conversa evidencia a perplexidade do filho, que destaca a avaliação sob normas morais: F: Não acredito!/ Como pôde?. Pa: Estava tentando ajudar pessoas. F: De modo errado. Pa: O que fez foi de coração. F: Ela nos desmoralizou. Pa: Não!. Mas o pai reconhece: Alguns não falarão mais conosco.

Sid, o filho, fica extremamente magoado com a mãe, passando a ignorá-la, em total desaprovação à prática do aborto. Ao falar com Vera, exaspera o tom de repúdio: F: Como pôde fazer isso, mãe? Não entendo. V: Não espero que entenda. F: Por que fazia isso? V: Tive que fazer. F: Estava tirando uma vida. Não percebe isso? V: Acho que não. F: Lógico que sim. São bebês/ Escutamos isso, lemos nos jornais, mas não esperamos que esteja tão próximo, com sua mãel Não tem direito.

A sacralidade da vida é um dos argumentos de Sid, que não pondera o sofrimento psicológico de Vera quando seus segredos vêm à tona. E "a doutrina da santidade da vida humana não é mais do que uma forma de afirmar que a vida humana tem algum valor muito especial, um valor totalmente distinto do valor das vidas de outros seres vivos". ${ }^{292}$ Destaque-se o fato de Sid equiparar fetos ou embriões a bebês, o que traz à colação a ideia de um verdadeiro continuиm vital.

Do ponto de vista da teoria pragmática da comunicação, torna-se patente a discussão-contra, com predomínio da heterologia, ou seja, emissor e receptor discutem um contra o outro, o que torna a relação um tanto desigual, já que trocam mensagens de forma partidária, sem que qualquer deles esteja aberto à possibilidade de convencimento.

${ }^{292}$ SINGER, Peter. Ética prática. São Paulo: Martins Fontes, 2002, p. 94. 
A omissão é encarada como uma mentira, e desde então, Sid não se dirige à mãe como fazia antes da descoberta. O relativismo axiológico torna-se, aqui, um verdadeiro conceito-imagem. Na lição de H. Tristam Engelhardt Jr., "a diversidade moral é real de fato e em princípio" e "o fracasso do moderno projeto filosófico de descobrir uma moralidade canônica essencial constitui a catástrofe fundamental da cultura secular contemporânea e enquadra o contexto da bioética hoje" 293

A reação de Joyce, cunhada de Vera, é também de contrariedade e hostilidade: Vaca estúpida! Como pôde ser tão egoísta?; mantém a sua aversão inclusive na reunião de Natal. Nessa ocasião, uma caixa de chocolates é aberta, e a simbologia possível é interessante. Vera pega um bombom e somente as personagens que compreenderam sua atitude, compadeceram-se e solidarizaram-se com seu sofrimento aceitam o chocolate. Sid e Joyce recusam comer o doce que Vera também comia.

Há uma nítida separação na sua família entre os que a condenaram e os que a perdoaram. Nesse passo, convém destacar que o perdão é uma verdadeira relação de poder que cada um reserva para si. "Não há a menor dúvida de que muitas proibições existem tão-somente para dar sustentação ao poder daqueles que podem punir e perdoar-lhes a transgressão",294.

A análise da película permite verificar que a prática do aborto toma corpo ora significando desconfirmação da norma posta, ora rejeição. Para Tércio Sampaio Ferraz Jr., enquanto, ao se rejeitar, nega-se a relação, "a desconfirmação é uma reação de desconhecimento da relação"295.

A hipótese da clandestinidade, inclusive no que diz respeito aos abortos praticados por médicos, denotam a rejeição, como já destacamos pouco acima. Apesar do descumprimento da norma, ela é tida como existente e aplicável pelos sujeitos da relação que se constrói, tanto que cuidam para que não sejam descobertos e apenados. Já a desconfirmação se deduz das referências à habitualidade da prática, bem como o fato de todos saberem - inclusive as autoridades.

No Tribunal, na ocasião do julgamento de Vera pelas leis, apresentam ao juiz as armas do crime - "nove provas". A defesa de Vera destaca que a sua caridade e

${ }^{293}$ ENGELHARDT Jr, H. Tristam, Fundamentos da Bioética. São Paulo: Loyola, 2004, pp. 21 e 34. O relativismo ético, no entanto, é contestado de forma ferrenha por Peter Singer. Veja, nesse sentido, Ética Prática, pp.12-16. Ainda ressalta-se BEAUCHAMP, Tom L.; CHILDRESS, James F. Principles of biomedical ethics. Oxford: Oxford University Press, 2001, p. 21.

${ }^{294}$ CANNETI, Elias. Massa e poder. São Paulo: Companhia das Letras, 1995, pp.298-299.

${ }^{295}$ FERRAZ Jr., Tércio Sampaio. Introdução ao Estudo do Direito: técnica, decisão, dominação. São Paulo: Atlas, 1994, p. 109. 
generosidade a levaram a ajudar outras mulheres. No entanto, o juiz a condena a 2 anos e 6 meses de prisão, aduzindo que a seriedade de seu crime merece reflexão e servirá como um aviso para quem quiser fazer isso.

$\mathrm{Na}$ cadeia, Vera encontra outras mulheres condenadas por praticarem aborto - o que reforça a ideia de ser um fato comum, uma prática usual na sociedade -, mas afasta-se delas. É interessante destacar, nesse contexto, a preponderância do relativismo, já que nem todas a mulheres presas tinham os mesmos ideais na prática de um aborto, ou a conduta marcada pela alteridade e caridade, tal como ocorria com Vera ${ }^{296}$.

Agora, passemos à análise da película de Cristian Mungiu, que também pode ser tomada de modo pertinente para estudo do embate entre relativismo e universalismo axiológico.

\subsection{Análise do filme 4 meses, 3 semanas e 2 dias}

Esse filme também fazia parte do programa elaborado pela Professora Orientadora para o curso de Pós-Graduação da Faculdade de Direito da Universidade de São Paulo, intitulado "Cinema e Filosofia do Direito: o problema da verdade e da justiça no exercício jurídico do poder", ministrado no primeiro semestre de 2010. As falas destacadas foram retiradas do filme.

Sob um novo enfoque, vale destacar como o fenômeno da rejeição normativa aparece em outro filme, com ponderações atinentes à justiça e ao relativismo axiológico, verificável pelos conceitos-imagem ${ }^{297}$.

A película romena dirigida por Cristian Mungiu retoma o assunto concernente ao aborto, destacando de modo ainda mais contundente o traço da clandestinidade na prática abortiva, realizada entre jovens estudantes. A temática revela a possibilidade de abordagem plural, com problematização que rompe a fronteira espacial. Por certo, a imagem expõe situações que poderiam facilmente ser verificadas cotidianamente, de modo universal. $\mathrm{O}$ aborto não é um problema brasileiro, localizado, restrito aos limites geográficos de nosso país.

\footnotetext{
${ }^{296}$ Cuida-se de conclusão a que chegamos após discussão do filme com a Professora Orientadora.

${ }^{297}$ CABRERA, Julio. O cinema pensa: uma introdução à Filosofia através dos filmes. Rio de Janeiro: Rocco, 2006, p. 22.
} 
Sobre o contexto em que se passa a história, remonta-se a período cronologicamente posterior àquele em que se desenvolve a narrativa de Vera Drake, sendo interessante estabelecer a qual época alude o filme.

Pois bem, em 1966, sobreveio uma lei proibitiva do aborto na Romênia e, em pouco tempo, até 1970, uma verdadeira explosão demográfica. Para ilustrar, Cristian Mungiu escreve que as salas de aula ficaram lotadas, subindo em média de 28 para 36 o número de alunos. A partir desse período, as mulheres passaram a apelar para o aborto clandestino e, ao final do Comunismo no país, pelo menos 500.000 mulheres haviam morrido em decorrência de complicações relacionadas ao aborto. A interrupção da gravidez tornou-se nesse período do Comunismo uma forma de insurgência e rebelião contra o regime. Depois de 1989, uma das primeiras medidas tomadas foi legalizar o aborto novamente ${ }^{298}$.

Nesse passo, destacamos a capacidade de a imagem conseguir tratar de temas que transcendem uma região do globo. É o que se depreende da lição de Julio Cabrera, segundo o qual

mediante esta experiência instauradora e emocionalmente impactante, os conceitos-imagem afirmam algo sobre o mundo com pretensões de verdade e de universalidade. Este elemento é fundamental, porque, se não conservamos as pretensões de verdade e de universalidade, dificilmente poderemos falar, de forma interessante e não meramente figurativa, de filosofia no cinema ou filosofia através do cinema. Esta é a única característica (...) O cinema é universal não no sentido do 'Acontece necessariamente com todo mundo', mas no de 'poderia acontecer com qualquer um' 299.

Diferentemente dos documentários que serão analisados, a história de 4 meses, 3 semanas e 2 dias supõe-se desde já fictícia. Assim, interessa destacar alguns diálogos presentes no filme, bem como descrever certas cenas, o que não tem a pretensão de substituir a situação-cinema, tal como definida por Hugo Mauerhofer ${ }^{300}$.

Como personagens centrais, e que logo aparecem, temos Otília e Gabriela Dragut (Gabita), que está grávida e deseja pôr fim na sua gravidez. As duas são estudantes e dividem um quarto em alojamento estudantil. A gravidez entre jovens ou adolescentes

\footnotetext{
${ }^{298}$ Informação disponível no site oficial: 〈http://www.4months3weeksand2days.com/blog/notes-from-thedirector/> Acesso em: 30 de abril de 2011.

${ }^{299}$ CABRERA, Julio. O cinema pensa: uma introdução à Filosofia através dos filmes. Rio de Janeiro: Rocco, 2006, p. 23.

${ }^{300}$ MAUERHOFER, Hugo. A psicologia da experiência cinematográfica. In: XAVIER, Ismail (org). A experiência do cinema. Rio de Janeiro: Edições Gerais Graal: Embrafilmes, 1983 p. 375
} 
pode ser apontada como um acontecimento verificável ao redor do globo, especialmente em determinadas camadas sociais ${ }^{301}$.

Um traço interessante no filme é a constante menção a produtos "renomados", ou mesmo mostrar esses produtos numa espécie de feira de troca existente, o que se relaciona ao momento histórico pelo qual passava o país em que o enredo se desenrola. Isto corrobora a tese de que o aborto é um tema que, além de ultrapassar fronteiras, é atemporal.

Gabita demonstra certa preocupação com os estudos, mencionando, a todo o momento, sua ansiedade, especialmente levando em consideração seu intento. Otilia é quem corre atrás de tudo, busca as coisas para a amiga, mesmo não tendo como pagar os bilhetes do transporte local - que acaba ganhando de um passageiro -, ou tendo de pegar dinheiro emprestado de seu namorado (300 lei, moeda local, para somar-se aos outros 2.700). Otilia mantém o segredo, deixando de dizer a Adi, seu namorado, o que fará: Eu vou dizer, mas não agoral Adi: Você não pode me dizer agora? Otilia: Você não confia em mim? Eles conversam mais um pouco e Adi pede que Otilia não se atrase para o aniversário em sua casa, confraternização que ocorrerá entre seus familiares (e pede para que ela chegue às 5 horas).

Pode-se dizer que segredo é um dos indicativos da clandestinidade, pois tudo deve ficar longe da oficialidade estatal. Procedimentos que rejeitam a autoridade constituída, por primeiro reconhecem-na como vigorante, mas por razões várias, como temor das consequências jurídicas ligadas à ação, são realizados furtivamente.

Na sequência, Otília sai, vai até um hotel e tenta reservar um quarto para realização do aborto. No entanto, a atendente lhe diz que o local está lotado e que não há nenhuma reserva que supostamente teria sido feita por Gabita. Otilia fala que a amiga havia ligado já, mas não encontra qualquer reserva - o que é confirmado por outro funcionário do hotel.

Assim, diante disso, Otilia sai e tenta encontrar outro quarto que esteja disponível, e se dirige a outro hotel. Porém também não há lugares disponíveis para hospedagem, pois só haveria um quarto vago no dia seguinte. No caso, trata-se de um quarto maior e, portanto, mais caro do que tinham previsto.

No desespero, Otilia acaba pagando o hotel. A atendente acha estranha a atitude da estudante: Se você está num alojamento, porque precisa de um hotel? Otilia então diz que

\footnotetext{
${ }^{301}$ BRUNO, Zenilda Vieira. Abortamento na adolescência. In: CAVALCANTE, Alcilene; XAVIER, Dulce (orgs). Em defesa da vida: aborto e direitos humanos. São Paulo: Católicas pelo Direito de Decidir, 2006, pp.81-92. A autora destaca que há uma relação entre baixa escolaridade e gravidez na adolescência.
} 
o alojamento está muito cheio e terão provas, sendo difícil para estudar. A moça soletra seu nome (Mihartescuscu) e informa o nome de Gabita (Gabriela Dragut). O quarto é caro, mas não há outra solução. Então liga à Gabita para dizer que conseguiu a reserva, explicando que teve de pagar mais caro por isso. São situações semelhantes, de desespero, que ensejam algumas atitudes por impulso. $\mathrm{O}$ aspecto psicológico ganha relevo, e muitas vezes a saúde mental acaba sendo abalada ${ }^{302}$.

Tendo conseguido o quarto, vai atrás do Sr. Bebe (Viorel), que seria o senhor responsável pela prática do aborto; num lugar afastado, pede informações sobre o aborteiro. Pergunta a um homem que está num carro vermelho que, por sinal, é quem Otilia procura. Ele estranha o fato de não ter sido Gabita a procurá-lo pessoalmente - pois era isso que havia sido combinado por telefone, mas Otilia justifica: Gabita não pôde vir, ela está passando mal. Eu sou Otilia. Diz que Gabita estará no hotel e tenta estabelecer um contato, mas o rapaz não é muito receptivo e parece contrariado pelo fato de Gabita não ter comparecido pessoalmente: Eu sempre encontro a pessoa primeiro, para ver se entendemos um ao outro. Otilia tenta acalmá-lo: Você pode confiar em nós, completamente.

Os cuidados de que se vale o homem revelam o intento de não dar qualquer alarde da atividade que pratica. Sr. Bebe pergunta em que hotel Gabita estaria, e Otilia responde. O homem censura, pois havia combinado em outros hotéis, locais em que as práticas abortivas eram realizadas corriqueiramente. Otilia explica que estavam cheios, não conseguindo alugar qualquer quarto.

Antes de dirigirem-se ao hotel, os dois passam por uma casa - supostamente a do Sr. Bebe. Ele demonstra postura rude, ríspida com uma senhora que estava sentada fora da residência, o que fica ainda mais claro quando ela diz que alguém ligou: Quantas vezes lhe falei para não atender o telefone quando eu estiver fora! Sr. Bebe pode ser caracterizado como um aborteiro, que cobra - caro - pelos serviços realizados. Trilha pelo caminho da rejeição à autoridade normativa, conforme claramente delineia cada uma de suas condutas.

Chegando ao hotel, os atendentes pedem a identificação - inclusive a de Viorel - e sobem para o quarto. Sr. Bebe está bravo com Gabita: Eu disse a você duas coisas pelo telefone: uma, pegue um quarto no Urinea ou Moldova. Duas, encontre-me pessoalmente. O Sr. Bebe ainda fala que deveriam ter esperado por um quarto vago noutro lugar, pois agora seu documento de identificação estava lá na recepção.

${ }^{302}$ Ibid., p. 83. 
A desconfiança e ansiedade que o rondam demonstram o receio de ser apanhado realizando o aborto. Por isso, a situação que saiu do seu esquema de controle estampa em suas ações uma preocupação. Fosse uma hipótese de desconfirmação, ser-lhe-ia indiferente o local em que interromperia a gravidez. Assim, a autoridade estatal faz-se presente, e dela se tenta ocultar a ação praticada ${ }^{303}$.

Ao ser indagada em qual mês da gestação estava, Gabita fala que aquele era o terceiro mês. Mas no telefone você disse que era o segundo, fala Bebe. A moça responde às perguntas do aborteiro sobre problemas de saúde (pressão alta, alergia, tipo sanguíneo etc).

Otilia pergunta se será utilizado anestésico, pois uma amiga que passara pelo procedimento disse que nela havia sido aplicado. Bebe é grosso, áspero: E você, já fez um aborto? Ele então fala que não será aplicado qualquer anestésico, que haverá sangramento e doerá um pouco. Além disso, é importante que ela fique absolutamente parada durante e após o procedimento. Gabita parece assustada, com medo, indecisa. Mas Bebe reforça dizendo que aquilo não era uma brincadeira: Podemos ir à prisão por isso. Quando começarmos, não há volta. Se tudo correr bem, depois que eu colocar a sonda dentro, você sangrará e o feto sairá. Diz ainda que depois do aborto, havia chance de infecção. Otilia indaga se poderia chamar uma ambulância, caso ela precisasse. Bebe explica como e o que ela deveria dizer.

Dessa fala, é fácil concluir que as intercorrências do aborto clandestino são muito mais frequentes. Isso pode estar relacionado ao método utilizado ou o estágio de desenvolvimento fetal: a interrupção de uma gravidez nos seus estágios mais avançados pode ter complicações que requerem um aparato médico-hospitalar mais sofisticado que, se ausente, aumenta o risco de morte da gestante ${ }^{304}$.

Ao contrário de Vera Drake, que se mostrava calma e tranquilizava as pacientes de modo afetuoso, sem cobrar pelo procedimento, o Sr. Bebe, apesar de explicar a realidade dos eventos, era mais ríspido e cobrava pelo aborto. Aliás, esta película mostra que o preço do aborto praticado em Gabita não se resumiu à pecúnia - insuficiente para o aborteiro.

Viorel apalpa a barriga de Gabita e pergunta: Quantos meses você falou? É melhor prestar atenção... Em seguida conta: Novembro, dezembro, janeiro, fevereiro. Dá quanto?

${ }^{303}$ FERRAZ Jr., Tércio Sampaio. Teoria da norma jurídica. Rio de Janeiro: Forense, 1978, p. 65. Verificamos nas normas proibitivas uma complementaridade imposta.

${ }^{304}$ TOOLEY, Michael; WOLF-DEVINE, Célia; DEVINE, Philip E.; JAGGAR, Alison M. Abortion: three perspectives. New York: Oxford, 2009, pp. 133-135. Alison M. Jaggar cita inúmeros procedimentos abortivos, relacionando-os à fase da gestação em que são aplicados. Escreve também que quanto mais tardios os abortos, mais caros e arriscados são. Isto porque demandam mais recursos médicos. 
Gabita não fala a data correta, mas nem tinha mesmo certeza de sua última menstruação: talvez um pouco mais de três meses. Bebe fala que não se trata de "talvez", mas sim bem mais de três meses. Então pede para que a moça se concentre e diga o período certo, já que o procedimento é diferente para o terceiro e quarto meses: você está jogando com os meses. Dependendo do período, não será aborto: eles a apanharão por assassinato ${ }^{305}$, com pena de 5 a 10 anos.

Mas Gabita se justifica, dizendo que seus períodos são irregulares. A moça implora para que o aborto seja praticado, e começa a discussão acerca do dinheiro. Otilia explica que tinham 3000 lei, mas precisaram gastar com o quarto mais do que havia sido previsto e só restaram 2850 lei. Viorel responde: Eu não falei do dinheiro? Otilia refere-se à Ramona, sua amiga, com quem conversara sobre o custo de um aborto clandestino: cerca de 3000 lei pelo procedimento. Viorel diz: Então deixe Ramona praticá-lo, já que ela é tão informada.

Depois Sr. Bebe fala: Eu não vou julgá-la pelo que aconteceu. Na vida, cometemos erros. Eu não perguntei nada, nem seu nome, nem o nome de seu pai. Não me interessa. Eu não escondi nada. Eu vim em meu carro, deixei meu documento de identificação na recepção. Se a polícia vier, me pegarão primeiro. Estou arriscando minha liberdade. Eu tenho uma família, um filho (...) que parte você não entendeu? Eu arriscaria 10 anos por 3000 lei? É isso que achou? Bebe vai ao banheiro e, ao retornar, quer ouvir o que Gabita decidiu.

Otilia diz que pegará o dinheiro que falta emprestado. Pagarão 2800 lei e depois mais 2000. Bebe não confia, e as chama de raposas, levantando-se para ir embora, mas Gabita o barra e implora para que ele faça o aborto naquele mesmo dia. Então revela que Otilia não era sua irmã, como havia dito inicialmente, desculpando-se por ter mentido.

Bebe resolve ficar, depois de muito esforço de ambas, e o preço é muito caro: Gabita sai do quarto, deixando Otilia e Bebe juntos. Depois de um tempo, Otilia vai ao banheiro e se lava, tudo pela amiga. O reflexo de Bebe pode ser visto no espelho do banheiro. Assim, além do dinheiro que lhe haviam pago, verifica-se o abuso da situação de fraqueza de ambas, complementando-se o dinheiro com relações sexuais, o que demonstra a ausência de escrúpulos dele.

Forram a cama com uma sacola plástica, Gabita toma um banho, troca o lençol e Viorel começa a se preparar para realizar o procedimento.

\footnotetext{
305 Pela legislação brasileira, ao contrário do que ocorre no filme, não há uma distinção entre aborto e homicídio de acordo com o período em que se encontra a gravidez.
} 
O trabalho da câmera é bastante interessante, pois só mostra uma parte do corpo das personagens, que exclui a face e boa parte dos membros inferiores. Esses jogos com os planos $^{306}$ contribuem para que as cenas causem uma sensação de repulsa naquele que as assistem.

Antes disso, Otilia ainda remexe a maleta do aborteiro, com cuidado para que ele não a veja, mas ele retorna sem que qualquer intento possa ser concretizado naquele ínterim. Na sequência que vemos, há uma sensação psicológica de um acontecimento que se desenvolve enquanto outro ocorre. De certo modo, fomos educados à compreensão dessa estrutura narrativa: "um salto qualitativo é dado quando o cinema deixa de relatar cenas que se sucedem no tempo e consegue dizer "enquanto isso",307.

A maleta é aberta e os instrumentos necessários para desinfecção e higienização podem já ser vistos. A sonda que será utilizada é esterilizada com os produtos trazidos. Não haverá injeção, responde Bebe à indagação de Gabita, nitidamente preocupada com a possível sensação de dor.

Otilia, nesta empreitada, acaba desempenhando o papel de auxiliar, entregando a Bebe as coisas que o homem pede. O procedimento é realizado com rapidez. Ao final, o homem aconselha: Não jogue o feto no banheiro, pois entupirá, seja inteiro ou em pedaços. E não enterre onde os cachorros possam cavá-lo. Além disso, diz que se ela precisar, ele ficaria à disposição, podendo passar por lá, e depois vai embora.

Otilia está um tanto desconcertada com a pessoa que Gabita arrumara para praticar o aborto: Estou curiosa para saber: Por que Ramona recomendou este Bebe? Gabita: Ele fez o aborto da Luciana. Otilia: Não foi o da Ramona? Gabita: Não. Além disso, questiona a amiga por que ela dissera que era sua irmã, e as atitudes que ela havia tomado quanto ao fato de não ter ido pessoalmente, mas Gabita nomeia sua atitude como mera omissão, e não mentira. Otilia estava mesmo chateada pelas coisas terem chegado àquele ponto daquela forma. Discutem um pouco mais e Otilia decide sair, para o aniversário na casa de seu namorado. Tranca Gabita no quarto.

Chega atrasada à casa de Adi, seu namorado. Está tensa, o se que percebe nos gestos e na face. Não aproveita a comemoração, pois pensa continuamente em Gabita que ficou no hotel. Tenta ligar no quarto 206, em que se hospedaram, mas não consegue falar com a amiga. É apresentada aos convidados e familiares do namorado, mas está dispersa,

\footnotetext{
${ }^{306}$ BERNADET, Jean-Claude. O que é cinema. São Paulo: Editora brasiliense, 2006, pp. 31-48. Há uma linguagem própria na sucessão de imagens trazida pelo cinema.

${ }^{307}$ Ibid., p. 33.
} 
ansiosa. Otilia e Adi parecem dois estranhos à mesa, pois não interagem com os convidados, que falam sem parar sobre os mais dispersos assuntos.

A interação entre os sujeitos do discurso, na verdade, é breve e não autêntica. Fazem algumas perguntas relacionadas ao cotidiano, e ela fica ofendida - sem dizer - pelo comentário sobre ela ser uma pessoa simples.

A esta altura, o namorado está muito desconfiado: Quer me dizer o que está acontecendo? Você está muito brava desde que chegou aqui. Depois de insistir, Otilia finalmente revela: Eu estava ajudando Gabita a realizar um aborto. Adi entende o motivo de ela ter lhe pedido dinheiro emprestado e eles começam a debater a situação, inclusive em termos hipotéticos: E se eu estivesse grávida, o que faríamos?, questiona Otilia; Eu quero saber o que esperar de você. Depois de uma conversa tensa, e de mais uma tentativa infrutífera de ligar ao hotel para falar com Gabita, Otilia decide partir. Está muito preocupada.

Volta ao hotel. Sua respiração está ofegante, e caminha por ruas escuras. Ao chegar ao quarto, Gabita está coberta, dormindo. Otilia acorda a amiga, que diz já ter "se livrado" do feto. Otilia vai ao banheiro, acende as luzes, abaixa-se um pouco e vê o feto no chão. Seu rosto mostra uma mistura de sentimentos; pega uma sacola plástica e o embrulha ${ }^{308}$. Depois apanha alguns panos para deixar tudo mais escondido. Ela tem de se livrar do feto - Gabita pede que Otilia o enterre.

A amiga sai do hotel e caminha mais uma vez por lugares ermos e isolados. Não há mais táxi ou ônibus naquele horário, é muito tarde.

Tenta jogar o feto algumas vezes, mas cães a acuam. Olha sempre para o lado para verificar se alguém a vê. Por fim, sobe as escadas de uma habitação e joga o feto embrulhado numa lata de lixo. Volta ao hotel e Gabita não está no quarto. Informam que ela havia descido até o restaurante. A moça que se sujeitou ao aborto acaba tendo um pouco de febre e bebe água.

Conversam um pouco, e a situação parece ter sido resolvida. Mas é um fim que não tem respostas fechadas. $\mathrm{O}$ filme fica aberto à problematização - como a responsabilidade que envolve a decisão de praticar um aborto, encarando-o como um ato moral. Gabita queria abortar, mas quem fez praticamente tudo foi Otilia.

Podemos sintetizar a grave situação que permeia a história de muitas pessoas com a observação de Celso Cezar Papaleo, segundo o qual "a clandestinidade abortiva é

\footnotetext{
${ }^{308}$ Ibid., p. 12. A imagem do feto é impactante, o que aumenta a sensação de realidade.
} 
patogênica, pelo risco de não só poder conduzir à doença e ao conflito, mas ainda pelo grave ônus de expor à sanha de profissionais desumanos, sem caráter, ${ }^{, 309}$.

A cena final do filme mostra as amigas numa mesa de restaurante, em uma atitude comum e corriqueira, num silêncio que comunica o desconforto.

Em comparação ao documentário $O$ grito silencioso, cuja análise será feita no capítulo que segue, não há, neste filme, discussão aprofundada sobre o status do feto. A abordagem sobre o aborto, no entanto, revela com maestria contornos da clandestinidade e da rejeição à autoridade constituída.

Feita essa análise, convém examinar, no capítulo que segue, se a vida humana pode ser considerada um preceito absoluto e em que sentido deve ser entendido.

Se for um preceito absoluto, não ficariam sem sentido as discussões sobre o aborto, visto que qualquer posição que lhe fosse contrária seria ofensiva a esse bem absoluto? Caso não seja a diretriz absoluta dos debates, existe alguma? De outro modo: qual a bússola que deve nortear os debates éticos concernentes à interrupção da gravidez? Como se colocam os estudos sobre a pessoa humana nos debates bioéticos? Há uma identificação entre ser e humano, de maneira que é indissociável a expressão pessoa humana? É suficiente, para o Direito e a Bioética, a individualidade genética? O que significa a desbiologização da pessoa?

É necessário analisar as consequências filosóficas de se tomar, nas discussões sobre o aborto, os parâmetros atinentes à vida e à pessoa humana. Com isso, será possível verificar os reflexos nas posturas universalistas e relativistas.

Passemos às discussões sobre o homem biológico.

${ }^{309}$ PAPALEO, Celso Cezar. Aborto e contracepção: atualidade e complexidade da questão. Rio de Janeiro: Renovar, 2000, p. 35. 


\section{CAPÍTULO 4 - A VIDA HUMANA: O HOMEM BIOLÓGICO}

Certifiquei-me de que a Moral e a Biologia se entrelaçam indissoluvelmente. Mais do que isto: essas duas ciências são reciprocamente complementares porque os 'bens soberanos' do espírito humano desabrocham sobre 'patrimônios genéticos condicionantes'.

(Estudos, Goffredo Telles Junior)

(...) o início da vida biológica humana não é o início de uma pessoa como agente moral. Em ontogenia humana vivem-se meses de vida biológica antes que haja suficiente prova da vida da mente - anos se passam antes que existam provas da vida de uma pessoa como agente moral. Como resultado, a condição moral dos zigotos, embriões, fetos e até bebês é problemática para a moralidade secular geral.

(Fundamentos da Bioética, H. Tristam Engelhardt Jr.)

\subsection{Considerações iniciais}

A vida humana pode ser considerada um tema universal. Com isso, quer-se dizer que ela interessa aos mais diversos ramos do conhecimento e expressão, cada qual considerando determinado aspecto como núcleo essencial, seja científico ou estético. São inúmeras as obras literárias, pinturas, fotografias, filmes que tomam a vida humana como fonte de inspiração.

Para o universo do Direito, é patente o interesse em sua proteção, já que o homem constitui o substrato biológico da pessoa ${ }^{310}$, sujeito de direito ${ }^{311}$. Pune-se, assim, a prática do aborto fora das hipóteses legalmente permitidas, sem mesmo perquirir acerca da

\footnotetext{
${ }^{310}$ FORD; Norman M. When did I begin?: conception of the human individualin history, philosophy and science. New York: Cambridge University Press, 1988, pp. 66-67. Como salienta o autor, "nossa concepção tradicional de pessoa é baseada no nosso entendimento de um ser humano, um humano individual. Nenhum de nós nunca encontrou uma pessoa que não fosse um ser humano individual. Nós não podemos explicar o que é uma pessoa sem se referir ao nosso conhecimento sobre os seres humanos adquiridos com a experiência (...) nós comumente nos referimos a um membro individual de nossa espécie numa conversa comum como Homo sapiens ou como humano individual ou ser humano. Pessoas comuns e uso linguístico comum também empregam o termo pessoa, entendido como uma pessoa natural" (tradução nossa). No original: "Our ordinary concept of human person is based on our understanding of a human being, a human individual. None of us has ever met a person that was not an individual human being. We cannot explain what a person is without reference to our knowledge of human beings gained from experience (...) We usually refer to a living member of our species in common conversation as Homo sapiens or as a human individual or a human being. Ordinary people and common linguistic usage also employ the term person, understood as a natural person".

${ }^{311}$ Embora nem todo sujeito jurídico possa ser considerado uma pessoa.
} 
existência, ou não, de uma pessoa. Tutela-se a vida intrauterina, em sentido puramente biológico.

A maioria das questões bioéticas tem em seu cerne o respeito e valor atribuídos à vida humana, de complexidade única na linha evolutiva. Daí advêm discussões que são travadas acerca da definição de vida, bem como sobre seu início e fim: a resolução dos dilemas éticos parece assentar-se no estabelecimento de marcos, a partir dos quais determinada conduta seria certa ou errada - o que se revela extremamente tormentoso a uma análise mais detida.

São inúmeras as indagações que se colocam na esteira desses debates, polarizandose muitas vezes a solução entendida como adequada, como pôde ser observado no capítulo precedente. Não poderia ser diferente no que concerne ao aborto - que é o mote deste estudo -, em que o começo da vida humana parece ser decisivo para a tomada de decisões.

Entretanto, seria suficiente a consideração do homem em sentido puramente biológico para análise do problema do aborto? Afinal, a vida humana deve sempre ser protegida? Qual vida humana? É possível estabelecer momentos que delimitem o começo e o fim do que se entende por vida humana? E o que se entende por vida humana? O nascimento pode ser considerado uma linha divisória no que concerne à proteção que se deve dar à vida do feto? O direito à vida pode ser considerado o grande problema moral do aborto?

Nesse passo, como pondera Goffredo Telles Júnior,

as revelações da Biologia Moderna hão de ter, por força, reflexos importantes nas disciplinas do comportamento humano. À luz dos novos conhecimentos, muitas concepções e muitas leis envelheceram. Em conseqüência, disposições importantes nas áreas da Moral e do Direito já vão sendo conscienciosamente revistas e substituídas. O sopro de uma nova Ética penetra a moderna legislação da convivência humana (...) já se sente a necessidade de reformular os conceitos de vida e de morte ${ }^{312}$.

Neste capítulo, traçaremos algumas considerações sobre o início da vida humana, o que também é tarefa árdua, pois são inúmeros os posicionamentos a estabelecer um marco inicial. Por opção metodológica, restringimos nossa análise aos ensinamentos médico-

${ }^{312}$ TELLES Jr., Goffredo. Estudos. São Paulo: Juarez de Oliveira, 2005, pp. 237-238. 
biológicos e filosóficos sobre o início da vida, sob pena de ampliarmos nosso estudo para além de seu foco.

É necessário deixar claro que nosso propósito não é especular a origem ou o início da vida humana biológica sem qualquer parâmetro. A pergunta que se faz não é simplesmente ‘quando há vida humana?', mas mais propriamente 'quando há vida humana individuada?'. Há, nessa indagação, uma diferença em que se assenta um critério empírico e valorativo, como se verá.

Interessa analisar, nesta oportunidade, as concepções autopoiética e biossemiótica sobre o início da vida humana, que têm sido pouco abordadas em estudos relacionados ao aborto, mas que representam uma nova reflexão de Filosofia da ciência biológica e encaram a vida humana inserida em um verdadeiro sistema biológico (autopoiese) de interação ou, por outro viés, possibilita uma nova abordagem da semiótica, aplicada para identificação de uma linguagem biológica.

Analisaremos, ainda, as bases da doutrina da sacralidade da vida (sactity of human life), que se apresenta arraigada a muitos julgamentos e decisões, apesar de inúmeros questionamentos que tendem a arrefecer os pilares em que se assenta. Nesse passo, importariam considerações atinentes à qualidade de vida? Podemos julgar se uma vida é melhor ou pior?

Ademais, é necessário investigar o argumento que, elaborado em termos de lógica formal, pretende demonstrar que o aborto é errado. Muitos estudiosos partem do seguinte silogismo para condenar as práticas abortivas:

Primeira premissa: é errado tirar a vida de um ser humano inocente;

Segunda premissa: da concepção em diante, o embrião ou o feto é um ser humano, inocente e vivo;

Conclusão: é errado tirar a vida de um embrião ou feto.

Ora, do ponto de vista da lógica formal, pode-se dizer que a conclusão seja verdadeira. Entretanto, o que se dizer sob uma ótica de lógica material? Convém investigar as premissas e as conclusões, não só sob o ângulo estritamente formal ${ }^{313}$.

Também importa destacar o pensamento de Hans Kelsen acerca da interpretação, já que o autor refuta com vigor uma verdade hermenêutica.

Antes, porém, vale tecer algumas considerações acerca das relações existentes entre normas de diferentes escalões, para chegarmos à conclusão que pode estar consubstanciada

\footnotetext{
${ }^{313}$ É o que faz Peter Singer, ao questionar a validade desse silogismo. Discorreremos com maior profundidade acerca desses argumentos neste capítulo.
} 
numa sentença, por exemplo. Dessa forma, entre as normas de escalão superior e as normas de escalão inferior, verifica-se uma relação de suprainfra ordenação, o que se relaciona à estrutura escalonada concebida pelo autor. As normas inferiores haurem seu fundamento de validade das normas superiores, e assim sucessivamente, até que se chegue ao ponto culminante da cadeia, que já não será uma norma posta por um ato de autoridade, mas pressuposta, denominada norma fundamental. As relações de validade, num sistema dinâmico, não se dão propriamente pelo conteúdo, de maneira que "todo conteúdo pode ser direito" 314 .

Também pode parecer singelo, no momento decisivo, estabelecer um processo silogístico simplório, partindo da norma de escalão superior. Contudo, e isto muito nos interessa, é preciso salientar que há nas normas a serem aplicadas uma relativa indeterminação. Deveras, "a norma jurídica geral é sempre uma simples moldura dentro da qual há de ser produzida a norma jurídica individual”315. Isso afasta um automatismo do intérprete, pois pressupõe uma atividade hermenêutica, de escolha, de percepção de um dos significados possíveis a vigorar num caso concreto.

A ideia de um julgador que se restringe a "ser a boca da lei" rui diante da perspectiva hermenêutica, que se agiganta e ganha importância em questões práticas. Essa relativa indeterminação tratada por Kelsen no capítulo final de sua Teoria Pura do Direito diz respeito ao fato de ter

sempre de ficar uma margem, ora maior, ora menor, de livre apreciação, de tal forma que a norma do escalão superior tem sempre, em relação ao ato de produção normativa ou de execução que a aplica, o caráter de um quadro ou moldura a preencher por este ato ${ }^{316}$.

Poderíamos relacionar essa indeterminação à textura aberta do Direito a que se refere Hart, que significa que "há áreas de conduta em que muitas coisas devem ser deixadas para serem desenvolvidas pelos tribunais ou pelos funcionários, os quais determinam o equilíbrio, à luz das circunstâncias"317.

\footnotetext{
${ }^{314}$ KELSEN, Hans. Teoria Pura do Direito. São Paulo: Martins Fontes, 2009, p. 221.

315 Ibid., p. 272.

${ }^{316}$ Ibid., p. 388

${ }^{317}$ HART, Herbert L. A. O conceito de Direito. Lisboa: Fundação Lacouste Gulbenkian, 2007, p. 148.
} 
Há, num e noutro autor, uma alusão ao processo criador dos tribunais, o que se afasta de qualquer possibilidade de que uma decisão, num caso, seja tomada como "a correta", ou a "única possível".

Esclarecemos que algumas ponderações deste capítulo constituem um aprofundamento e uma revisão do que escrevemos no trabalho desenvolvido a título de Iniciação Científica, no período de 2005 a 2006, sendo bolsista da CNPq, intitulado de "O Aborto de Feto Anencefálico - entre o Ser e o Dever-Ser", apresentado com modificações a título de trabalho de conclusão de curso em 2007.

Urge observar que as especificidades acerca do problema do aborto do feto anencéfalo não constituem objeto deste trabalho, motivo pelo qual somente utilizamos algumas das considerações sobre o início da vida biológica, especificamente, algumas das reflexões presentes no item 3.2.1, sobre o início da vida do ponto de vista da Biologia e da Medicina. Consideramos que o pensamento pode ser expandido neste trabalho, quando ligado às considerações éticas do aborto em geral, e não unicamente do feto portador de anomalias. Não só: esse saber pode ser aliado à ilustração e reflexão logopática que o cinema apresenta, expandindo a forma interdisciplinar de compreensão da problemática do aborto.

No trabalho citado, de nossa autoria, pode ser encontrado um amplo histórico do aborto e, ademais, outras concepções sobre o início da vida humana, como a concepção relacional ou sociológica.

\subsection{Início da vida: o Homo sapiens}

O ser humano, como substrato biológico da pessoa, é antes de tudo um animal, pertencente à espécie Homo sapiens. Encontra-se no ápice da linha biológica evolutiva, sendo dotado de um complexo sistema nervoso que serve de aporte para a razão ${ }^{318}$ - o que o insere em um mundo mais que puramente social: um mundo de cultura, que cria e transforma.

318 Existe uma discussão acerca da possibilidade de identificação entre a mente e o cérebro. Alguns sustentam que a primeira é eminentemente imaterial, não se confundindo com o cérebro. Outros proclamam a necessidade de separação entre cérebro e mente. Parece-nos inegável que, conquanto não haja identidade entre um e outro, a mente e as faculdades mentais somente são possíveis pelo cérebro. Nesse sentido, são interessantes os argumentos trazidos por Michael Tooley (TOOLEY, Michael; WOLF-DEVINE, Célia; DEVINE, Philip E.; JAGGAR, Alison M. Abortion: three perspectives. New York: Oxford University Press, 2009). 
Nesse passo, como ensina Fábio Konder Comparato, é claro que a racionalidade propriamente humana reside na capacidade de inventar e "não pode ser reduzida ao simples comportamento intuitivo e mimético dos animais". Continua o autor dizendo que

a capacidade inventiva do homem acabou por levá-lo a intervir em seu próprio processo genético, tranformando-o em deus ex machina de si mesmo. A descoberta do chamado código genético, nos anos 50 do século $\mathrm{XX}$, foi o ponto de partida para a mais radical revolução técnica de todos os tempos: a era da bioengenharia. Com isto, Prometeu realizou o seu último e mais audacioso desafio ao Olimpo: entregou ao homem o domínio criador da própria vida ${ }^{319}$.

Toda essa complexidade biológica que particulariza a espécie humana é formada por apenas 46 cromossomos em cada célula, dispostos em pares. Será essa herança ou conformação genética que determinará muito do que cada organismo pode ser e que se torna aberta à possibilidade de interferência humana na manifestação de caracteres. $\mathrm{O}$ projeto Genoma Humano insere-se nesse novo cenário, em que o código humano se torna um livro que pode ser lido, e cada informação contida nos genes revela dados fantásticos, que podem ser manipulados e até reescritos.

Além disso, é terminologia comumente empregada pelos diplomas legais brasileiros o vocábulo "humano". Fala-se em dignidade da pessoa humana (artigo 1º, inciso III, Constituição Federal), direitos humanos (artigo $4^{\circ}$, inciso II, Constituição Federal), zigoto humano e embrião humano (artigo 25 da Lei $\mathrm{n}^{\mathrm{o}} 11.105 / 05$ ), veda-se o tratamento desumano (artigo $5^{\circ}$, inciso III da Constituição Federal), entre outras expressões, o que parece indicar a especial proteção que o Direito confere à vida humana ${ }^{320}$.

Porém, o termo "humano", se em algumas expressões indica tão-somente uma circunstância biológica, em outras aponta para o que Joseph Fletcher, teólogo protestante

\footnotetext{
${ }^{319}$ COMPARATO, Fábio Konder. Fundamento dos direitos humanos, p. 11. Disponível em: www.iea.usp.br/artigos.

${ }^{320}$ SINGER, Peter. Rethinking life and death: the collapse of our traditional ethics. New York: St. Martin's Griftin, 1994, p. 204. "Muitas pessoas tendem a se apegar ao estatuto superior do ser humano. Nós também estamos tão acostumados a falar em direiros humanos, dignidade humana, e sobre o infinito valor da vida humana, que não iremos abandonar facilmente a ideia de que ser humano em si é ser muito especial. Em parte, o problema é que a palavra 'humano' não é um termo puramente descritivo. Ele pode significar simplesmente um membro da espécie Homo sapiens, mas também pode ter construído em si as exatas qualidades que consideramos tornar os seres humanos especiais" (tradução nossa). No original: "Many people will want to cling to the superior status of the human being. We are so used to talk of human rights, human dignity, and the infinite value of human life, that we will not easily abandon the idea that to be human is in itself to be very special. In part, the problem is that the very word 'human' is not a purely descriptive term. It can mean simply a member of the species Homo sapiens, but it can also have built into it the very qualities that we think make human beings special".
} 
estudioso de assuntos relacionados à Bioética, denominou de "indicadores de humanidade" (indicators of humanhood), características propriamente humanas, como autoconsciência, autocontrole, senso de futuro e passado, capacidade de relacionar-se com os outros, comunicação e curiosidade. Com isso, na verdade colacionava atributos da "pessoa". Após o capítulo que segue, ficará mais clara a delimitação do termo "humano", em comparação ao que entendemos por "pessoa". As leis contêm um elemento linguístico e devem ser interpretadas: não podemos nos esquecer de que palavras são signos ${ }^{321}$. Dessa forma, a que “vida" se refere o artigo $5^{\circ}$, caput, da Constituição Federal?

Ainda uma questão tormentosa desponta: quando, afinal, começa a vida humana? Ora, se a vida humana é protegida pelo Direito, importa saber a partir de que momento surge um ser pertencente à espécie Homo sapiens: "as questões relativas ao começo da vida humana são ainda mais perturbadoras e colidem ainda mais substancialmente com as preocupações morais referentes à impropriedade do aborto e do infanticídio"322 .

Além disso, demarcar o início da vida humana pode ser também uma tentativa de separar as coisas não animadas (brutas) dos seres vivos - aquelas, nítidos instrumentos para realização das necessidades e faculdades humanas.

Não há consenso entre estudiosos do assunto, cada qual apontando um termo inicial a partir do qual haveria vida humana. O fato é que delimitar um ponto do processo vital que seja o limiar biológico de um novo ser revela-se, muitas vezes, como uma questão pragmática e cultural. Mais uma vez, sobreleva a estrutura dialógica das discussões.

A cientificidade de um critério, em termos de verificação e experimentação, parece não funcionar como exclusão das outras possibilidades aventadas por outros estudiosos, o que torna tanto mais complicada a empreitada de responder à questão.

Interessa analisar alguns dos principais posicionamentos médico-biológicos acerca do início da vida.

\subsubsection{Concepções médico-biológicas sobre o início da vida humana}

Com os novos avanços científicos, a vida tornou-se cada vez mais próxima, mais palpável, desvendando-se o funcionamento de um verdadeiro microcosmo biológico, as

\footnotetext{
${ }^{321}$ FERRAZ JR., Tércio Sampaio. Introdução ao estudo do Direito: técnica, decisão, dominação. São Paulo: Atlas, 1994, p.255.

${ }^{322}$ ENGELHARDT JR., H. Tristram. Fundamentos da Bioética São Paulo: Loyola, 2004, p.308.
} 
células. Além disso, veio a lume o que parecia insondável: a informação genética celular, dando novo rumo à Medicina.

Novas técnicas e especialidades médicas surgiram a partir do estudo da vida pósconcepção, como a Medicina Fetal, com a possibilidade de inúmeros procedimentos ainda no útero materno, o que elevou a condição do feto à de verdadeiro paciente. A vida, em geral, é de certa maneira associada ao movimento, e ver o desenvolvimento de um ser humano ainda no ventre materno conduziu algumas pessoas a um certo encantamento, contribuindo para o fortalecer os argumentos antiaborto.

Por outro lado - paradoxalmente - poder detectar, ainda nos primeiros estágios de desenvolvimento do embrião e do feto, anomalias fetais incuráveis propiciou novos debates em torno do aborto, ampliando a defesa da possibilidade de se interromper a gravidez em determinados casos, como uma escolha a ser tomada pela mãe ou casal. Dessa forma, não somente a vida biológica como critério mas também a qualidade de vida tornaram-se fatores determinantes para a decisão, e um novo paradigma para a Bioética.

Avulta-se uma nova ética acerca do início da vida considerando-se a possibilidade recente de geração de embriões in vitro, o que significou uma verdadeira revolução científica e social nos padrões de procriação, com redefinição da paternidade e da maternidade.

Em 1978, o nascimento de Louise Brown colocou um novo problema com relação ao status da vida humana em seus primórdios, pois Louise Brown foi o primeiro ser humano a nascer de um embrião que tinha sido fertilizado fora de um corpo humano ${ }^{323}$.

No entanto, como já afirmamos pouco acima, nem mesmo no meio científico há concordância acerca da fixação de um momento a partir do qual se possa dizer que já existe um novo ser humano. Diante disso, as críticas a uma e outra corrente surgem, numa tentativa mútua de desconstrução, sem que isso de fato ocorra, permanecendo cada qual na defesa de seus pilares.

Uma das primeiras correntes acerca do início da vida humana é a que toma como marco a concepção. Assim, desde a união entre os gametas masculino e feminino poder-seia afirmar o surgimento de um ser vivo pertencente à espécie Homo sapiens. É o que muitos juristas tomaram como premissa fundamental, adotando a tese que se convencionou

${ }^{323}$ SINGER, Peter. Ética prática. São Paulo: Martins Fontes, 2002, p.146. 
chamar de concepcionista. Além disso, a Convenção Americana de Direitos Humanos (Pacto de São José da Costa Rica) estabelece, em seu artigo 4 $4^{\mathrm{a}}$, 1, que em geral o direito à vida deve ser protegido desde a concepção.

No entanto, o que se quer dizer com concepção? Seria a mera junção de patrimônios genéticos parciais (23 cromossomos) que dá azo a um novo ser (com 46 cromossomos), o que abrangeria também a concepção extracorpórea, possível graças às técnicas de reprodução assistida que despontaram nas últimas décadas?

A questão não é tão simples como aparenta, envolvendo um verdadeiro problema etimológico e, inclusive, de mudança de significado pelo qual passou a palavra concepção. Isso parece ser olvidado por muitos autores, mas pode ser esclarecedor em inúmeros aspectos, como se verá.

Vale destacar, de início, que antes mesmo de se principiar a fecundação, ocorrem os processos formadores dos gametas. São etapas que precedem a fertilização, denominadas espermatogênese e ovogênese, espécies do gênero gametogênese. Aos gametas, células haploides resultantes desses processos, em que pese a importância para formação de um novo ser, não se atribui o mesmo valor de uma célula fecundada ${ }^{324}$.

Depreende-se da análise dos ensinamentos de Moore e Persaud, que

\begin{abstract}
o desenvolvimento humano é um processo contínuo que se inicia quando um ovócito (óvulo) de uma fêmea é fertilizado por um espermatozóide de um macho. A divisão celular, migração celular, a morte celular programada, a diferenciação, o crescimento e o rearranjo celular transformam o ovócito fertilizado - o zigoto - numa célula altamente especializada e totipotente, em um organismo humano multicelular. Embora a maior parte das mudanças no desenvolvimento se realize durante os períodos embrionário e fetal, ocorrem mudanças importantes nos períodos posteriores do desenvolvimento: infância, adolescência e início da idade adulta ${ }^{325}$.
\end{abstract}

A simplicidade da definição de fertilização (encontro dos gametas), não revela a maior complexidade subjacente ao processo cujo resultado final será um zigoto $^{326}$. A

\footnotetext{
${ }^{324}$ SINGER, Peter. Unsanctifying human life. Oxford: Blackwell, 2002, p.182. Como escreve o autor, "nós não conhecermos ninguém que declare seriamente o estatuto moral de um óvulo e espermatozoide antes da fertilização é tal que, em consequência, torna-se errado destruí-los" (tradução nossa). No original: "we do not know of anyone who seriously asserts that the moral status of the egg and sperm before fertilization is such that it is wrong to destroy them".

${ }^{325}$ MOORE, Keith; PERSAUD, T. V. Embriologia clínica. Rio de Janeiro: Elsevier, 2008, p.2.

${ }^{326}$ FORD; Norman M. When did I begin?: conception of the human individualin history, philosophy and science. New York: Cambridge University Press, 1988, p. 102. "A fertilização não é um evento
} 
fecundação também pode ser dividida em fases, o que torna imprecisa a ideia corrente segundo a qual a vida se iniciaria a partir da fecundação. Ora, esta não é um momento, não se delimita em um marco temporal preciso e único. Desconsiderar esse fato é manipular a realidade biológica em um discurso que não subsiste a uma análise mais rigorosa.

Esse verdadeiro processo pode ser assim esquematizado em inúmeras etapas, a saber: a) passagem do espermatozoide através da corona radiata, b) penetração na zona pelúcida; c) fusão das membranas plasmáticas do ovócito e do espermatozoide, d) término da segunda divisão meiótica e formação do pronúcleo feminino, e) formação do pronúcleo masculino, f) fusão dos pronúcleos ${ }^{327}$.

A fertilização, que ocorre na tuba uterina, é de fato um processo. Tanto o é que suas etapas podem ser manipuladas ou interrompidas, mesmo após o espermatozoide ter penetrado no óvulo, impedindo-se, por exemplo, a fusão dos pró-núcleos ${ }^{328}$.

Terminologia inútil, mas que cativou muitos autores, foi o termo pré-embrião, que seria o momento imediatamente anterior à fusão dos pró-núcleos - como se isso dignificasse o tal estado celular precedente à fusão das células gaméticas, quase de modo a equipará-lo ao próprio embrião, formado ulteriormente. A pensar logicamente, e tomando essa premissa equivocada, qualquer gameta seria pré-embrião, já que de certa forma é anterior à sua formação, o que conduz a um raciocínio ad infinitum.

Pré-embrião não é embrião, e nem será, necessariamente. Aprofundaremos essa questão ao tratarmos do argumento da potencialidade, que ainda grassa inúmeros adeptos nos debates bioéticos - mas que carece da solidez necessária para sua própria sustentação.

Nesse ponto, urge destacar que a ideia de que o homem biológico tenha início com a concepção quase sempre desconsidera a questão atinente à linguagem, especificamente envolvendo a ambiguidade da palavra "concepção" - mas que merece ser abordada.

Mesmo os conceitos normativos, por serem formados por palavras, podem apresentar uma tecitura fluida, aberta, indeterminada - daí a importância de que se revestirá a interpretação. Hart fala em uma verdadeira textura aberta que existe quando se

momentâneo, mas um processo que pode durar de 20-24 horas, começando com o primeiro contato do esperma com a membrana plasmática do ovócito secundário (óvulo) e terminando com a mistura dos cromossomos materno e paterno (singamia) para constituir o zigoto" (tradução nossa). No original: "Fertilization is not a momnetary event but a process that may last up to 20-24 hours, beginning with the first contact of the sperm with the plasma membrane of the secundary oocyte (ovum) and finishing with the mixing of the maternal and paternal chromossomes (syngamy) to constitute the zygote".

327 MOORE, Keith; PERSAUD, T. V. Embriologia clínica. Rio de Janeiro: Elsevier, 2008, p. 34.

${ }^{328}$ ZEGERS H. Fernando. Reflexiones sobre los inicios del individuo humano. Rev. Med. Chile, $\mathrm{n}^{\circ}$ 125, 1997, pp. 1500-1507. O autor apresenta uma interessante reflexão sobre as etapas e o processo de formação do zigoto. 
utiliza formas linguísticas gerais na comunicação de padrões de comportamento. Em consequência disso, "em qualquer sistema jurídico, deixa-se em aberto um vasto e importante domínio para o exercício do poder discricionário pelos tribunais e por outros funcionários" 329 .

Destaca Tércio Sampaio Ferraz Jr. que

ao disciplinar a conduta humana, as normas jurídicas usam palavras, signos lingüísticos que devem expressar o sentido daquilo que deve ser. Este uso oscila entre o aspecto onomasiológico da palavra, isto é, o uso corrente para a designação de um ato, e o aspecto semasiológico, isto é, a sua significação normativa. Os dois aspectos podem coincidir, mas nem sempre isto ocorre ${ }^{330}$.

Só por isso já se tem ideia da possibilidade de manipulação de conceitos linguísticos.

Os símbolos podem apontar para significados distintos, o que torna uma palavra plurívoca; e acreditar que os símbolos linguísticos não são passíveis de controvérsia quanto ao seu sentido é laborar é equívoco. A complexidade do Direito e das ciências humanas, de um modo geral, advém das inúmeras possibilidades de compreensão do objeto, que não se toma em termos exatos e matemáticos.

No caso do termo "concepção", no uso popular inicial, ele não tinha relação estrita com a ideia de início da vida. Indicava, simplesmente, que uma mulher havia engravidado e um feto começara a crescer em seu ventre. O cerne do vocábulo remete à gravidez, e não a indagações acerca da individualidade da vida fetal.

A origem do termo é latina. No latim, concipere, que originou conceive e conceber, significava receber o que já estava fecundado ${ }^{331}$. Ou seja, é muito mais próximo do que denominamos de nidação, implantação da célula fecundada no útero.

${ }^{329}$ HART, Herbert L. A. O conceito de Direito. Lisboa: Fundação Lacouste Gulbenkian, 2007, p.149.

${ }^{330}$ FERRAZ Jr., Tércio Sampaio. Introdução ao estudo do Direito: técnica, decisão, dominação. São Paulo: Atlas, 1994, p. 254.

${ }^{331}$ FORD , Norman M. When did I begin?: conception of the human individual in history, philosophy and science. Cambridge: Cambridge University, 1988, p. 8. "O significado original da palavra inglesa conceive, 'conceber', refere-se à mulher recebendo a semente em seu ventre e se tornando grávida ao tomar o feto para si. Esta é a essência do significado ativo de concepção. A palavra inglesa tem primariamente o significado de 'tomar efetivamente, tomar para alguém, apreender e manter. A palavra conceber vem do latim concipere, cujo significado geral é 'tomar ou lançar mão de, tomar para si, assimilar, tomar, receber etc'. O significado biológico é 'tomar ou receber o resultado da fecundação (animal ou vegetal), receber, se tornar grávida'. A compreensão simples e primitiva de concepção é a da fêmea mamífera mantendo o sêmen, que de modo misterioso conduz ao início de uma nova vida, e assim permite a ela que gere a descendência em seu útero. O significado passivo de concepção se refere à criança ou descendência sendo criada ou formada no útero e assim começando a existir. Nesse último sentido a ênfase está na origem da criança ao invés da ação 
Faz pouco mais de um século que o termo passou a ser identificado com o processo de fertilização ${ }^{332}$, num sentido passivo do termo, contrapondo-se à implantação, que poderia ser tomada em um significado ativo, já que considera o papel crucial da gestante, em cujo corpo se implanta a célula fecundada.

Enfim, tentar demarcar o início da vida a partir da concepção apresenta alguns problemas: a) o próprio termo é equívoco, apontando para no mínimo dois significados possíveis, quais sejam a fertilização e a nidação; b) se a especificação do termo eleger a fertilização como sinônimo, surge o problema concernente ao fato de a fertilização ser um processo, não um momento específico. É necessária, nesse aspecto, uma verdadeira reflexão filosófica ${ }^{333}$.

Mas não é só: podemos considerar que, ao final do processo de fertilização, quando se forma um zigoto pertencente à espécie humana, restará formado um indivíduo, cuja dignidade biológica o tornaria intangível? Trata-se de uma nova dificuldade de se tomar a fecundação como critério para início da vida. Que vida? Somente o código genético humano? Se for esta a opção, não haverá duvida de que a célula fecundada é diploide e contém um código genético dos pertencentes à espécie Homo sapiens. Mas outras células de nosso corpo, também diploides, contêm o material genético humano e não recebem semelhante tratamento.

Outra dificuldade, que torna insustentável a ideia de que, desde a concepção ou formação do zigoto, há vida individuada diz respeito à possibilidade de surgimento de gêmeos. É incompatível a noção de unicidade moral com a separação das células e origem de mais de um embrião. Como justificar, nesse caso, que um ser único biparta-se e origine outros seres? O ser inicial teria desaparecido?

da mãe" (tradução nossa). No original: "The original meaning of the English word conceive refers to a woman receiving the seed in her womb and becoming pregnant by taking her fetus herself. This is the essence of the active meaning of conception. The English word has the primary meaning of 'to take effectively, take to oneself, take in and hold. The word conceive comes from the Latin concipere whose general meaning is 'to take or lay hold of, to take to oneself, to take in, take, receive, etc'. Its biological meaning is 'to take or receive (animal or vegetable) fecundation, to receive, become pregnant'. The simple primitive insight expressed by conception is that of a female mammal holding on to the semen which in some mysterious way leads to the start of a new life and thereby enables her to bear offspring in her womb. The passive meaning of conception refers to the child or offspring being created or formed in the womb and thereby beginning to exist. In this latter sense the emphasis is on the origin of the child rather than the action of the mother."

${ }^{332}$ Ibid., p. 10. "Por volta dos últimos cem anos, o processo de fertilização começou a ser identificado com a concepção na visão da maioria das pessoas" (tradução nossa). No original: "Over the last hundred years or so, the process of fertilization has become to be identified with conception in the view of most people".

${ }^{333}$ BESIO R. Mauricio. Inicio de la vida humana: la necesidad de una reflexión filosófica. Rev. Med. Chile, $\mathrm{n}^{\circ} 125,1997$, pp. 1494-1499. 
A objeção soa muito plausível, de fato. Desconsiderar a gemelaridade - evento biológico natural, e que pode ser induzido em laboratório - é ignorar um fato importante para discussão do status moral do zigoto, embrião e feto. Ora, se entendermos que desde a fecundação, ou mesmo na formação do zigoto, já existe um ente individualizado, a geração de outros seres possibilitaria a equiparação do humano a organismos que se reproduzem desta maneira, assexuadamente, como bactérias. Isso produziria um efeito oposto ao que se pretende: ao contrário de dignificar, reduziria a condição biológica do Homo sapiens.

De fato, parece ser verdade que uma nova vida humana começa a existir quando um esperma humano une-se a um óvulo humano; pois a entidade que daí resulta - o zigoto - não parece ser idêntica nem ao esperma, nem ao óvulo; ele está indiscutivelmente vivo (ao invés de inanimado ou morto) e é geneticamente humano (...) Mas do fato de que algo vivo e humano comece a existir aproximadamente no momento da concepção não se segue que você e eu começamos a existir no momento da concepção (...) A ciência pode dizer muitas coisas sobre organismos humanos, mas não pode afirmar se somos organismos humanos $^{334}$.

É inegável que a continuidade ontológica do zigoto desaparece com o surgimento de gêmeos. ${ }^{335}$ Assim, novos critérios são tomados para, numa visão médico-científica, apontar o início da vida.

${ }^{334}$ MACMAHAN, Jeff. A Ética no ato de matar. Porto Alegre: Artmed, 2011, p. 16.

${ }^{335}$ FORD , Norman M. When did I begin? conception of the human individual in history, philosophy and science. Cambridge: Cambridge University, 1988, pp. 119 e 173. "A continuidade do mesmo indivíduo ontológico cessa quando o zigoto forma gêmeos. O zigoto não é mais o indivíduo ontológico ou um dos gêmeos resultantes de seu desenvolvimento, contudo sua identidade genética continua em todas as clivagens subsequentes/ Alguém que advogue a tese de que o indivíduo humano começa no estágio de zigoto poderia, em teoria, sugerir que o embrião humano tem a potência de formar gêmeos idênticos até o estágio da linha primitiva. Nesse sentido, o indivíduo embrionário humano seria comparado a células de bactéria ou ameba. Mas essa possibilidade teórica falha, como já vimos, pela falta de evidência em mostrar que o zigoto é um indivíduo humano (...) Isto porque as condições para a presença de um indivíduo humano, no sentido de um indivíduo ontológico contínuo com a verdadeira natureza humana, não são identificáveis antes da formação da linha primitiva" (tradução nossa). No original: "the continuity of the same ontological individual ceases when zygote forms twins. The zygote is not the same ontological individual as either one of the eventual twins that result from its development, notwithstanding its genetic identity continuing throughout all its subsequent cleavages". E, mais adiante, sustenta: "One who holds the view that the human individual begins at the zygote stage could in theory suggest that the embryonic human individual has the potency to form identical twins up to the primitive streak stage. In this respect the embryonic human individual would be compared to the bacterial cell or the amoeba. But this theoretical possibility fails, as we have already seen, for lack of evidence to show that the zygote is a human individual (...) This is so because the conditions for the presence of an actual human individual, in the sense of an on-going living ontological individual with the true human nature, are not satisfied prior to the formation of the primitive streak". Cf. SINGER, Peter. 
Em breves linhas, importa assinalar algumas etapas do desenvolvimento embrionário que seguem à fertilização. Isto porque a organização celular que toma curso logo após a formação do zigoto, bem como o aparecimento de determinadas estruturas, podem ser apontados como etapas relevantes para consideração da vida humana, a partir das quais se justificaria a defesa dessa vida.

Após a fecundação, forma-se uma célula, que contém um arranjo genético único, resultado da fusão da herança genética presente nas células gaméticas masculina e feminina. Eis o zigoto, que durante a clivagem divide-se, gerando duas células indiferenciadas, ou seja, idênticas, com o mesmo material genético. Cada célula pode ser considerada um ente individual, totipotente, e que pode dar origem a um ser humano ${ }^{336}$. A divisão repete-se em progressão geométrica, originando 4, 8, 16 células, assim sucessivamente. Tais células são denominadas blastômeros.

Cada uma dessas células pode ser tomada separadamente, como se ainda não se ligasse ao conjunto. Essa independência é acentuada pelo fato de inexistir uma ligação profunda que as tome como integrantes de um ser individuado. O que há, na verdade, é um aglomerado celular.

Em três ou quatro dias após a fecundação, os blastômeros mudam de forma, juntando-se uns aos outros até formarem uma bola compacta de células, denominada mórula (do latim morus, que significa amora, nome justificado pelo aspecto desse conjunto de células compactado). ${ }^{337}$ As células que antes se dividiam em outras células idênticas - e independentes - começam a tomar um curso ligeiramente distinto umas das outras. Os blastômeros agora se dividem transversalmente e a compactação das células muda, por exemplo, a velocidade de divisão celular: as células internas dividem-se mais rápido que as externas $^{338}$

A mórula forma em seu interior uma cavidade cheia de fluido - e passa a ser chamada de cavidade blastocística. Surge o blastocisto (blastos quer dizer germe e kystis, bexiga), que constitui o primórdio ou início do embrião (do grego embryon). Em seguida, o

Rethinking life and death: the collapse of our traditional ethics. New York: St. Martin's Griffin, 1996, pp. 94-95. Singer corrobora esta ideia.

${ }^{336}$ FORD , Norman M. When did I begin?: conception of the human individual in history, philosophy and science. Cambridge: Cambridge University, 1988, p. 133. O potencial de cada célula é o mesmo do zigoto.

${ }^{337}$ MOORE, Keith; PERSAUD, T. V. Embriologia clínica. Rio de Janeiro: Elsevier, 2008, p.2. "Esta massa sólida com cerca de 13 a 32 blastômeros é formada pela clivagem do zigoto".

${ }^{338}$ FORD , Norman M. When did I begin?: conception of the human individual in history, philosophy and science. Cambridge: Cambridge University, 1988, p. 146. 
blastocisto implanta-se no útero materno. Poderá ocorrer, no entanto, gravidezes ectópicas e abortamentos espontâneos ${ }^{339}$.

No caso da fertilização in vitro, não se implanta o embrião. Assim, é extremamente limitado o seu desenvolvimento: nunca poderá crescer e se desenvolver, o que, no atual estado médico-tecnológico, revela o papel ativo da mãe, que é crucial para a completa formação do feto. $\mathrm{O}$ velho argumento da potencialidade reveste-se de um matiz diferenciado em relação ao embrião, caso esteja ou não implantado, o que parece conduzir a uma potencialidade ativa mitigada, no caso da não implantação, como veremos com mais vagar.

Em seguida, inicia-se a gastrulação (do grego gaster, que significa estômago). O blastocisto transforma-se em gástrula, quando já se pode falar em origem de um estômago primitivo. A gástrula possui camadas germinativas que recebem o nome de ectoderma, mesoderma e endoderma. São estas camadas que irão se diferenciar nos órgãos e tecido do embrião $^{340}$.

No curso do desenvolvimento embrionário que continua, temos a neurulação (do grego neuron, nervo), quando se começa a formar as primeiras estruturas nervosas do novo indivíduo: o tubo neural é a base do sistema nervoso central, formado pelo encéfalo e pela medula espinhal. Durante a terceira e quarta semanas, aproximadamente, o embrião é chamado de nêurula ${ }^{341}$.

Finalmente, tem lugar a organogênese, etapa em que há a diferenciação das células primárias para originar os órgãos, sucedendo então o período fetal.

\footnotetext{
${ }^{339}$ MOORE, Keith; PERSAUD, T. V. Embriologia clínica. Rio de Janeiro: Elsevier, 2008, p. 2 e seguintes. Como ensinam os autores, "uma grande quantidade de zigotos, mórulas e blastocistos aborta espontaneamente. A implantação inicial do blastocisto representa um período crítico de desenvolvimento que pode falhar em virtude da produção inadequada da progesterona e estrogênio pelo corpo lúteo (...) Acreditase que a taxa de abortamento espontâneo precoce seja em torno de $45 \%$ ". E, mais adiante, relatam que "a maioria dos abortos de embriões durante as primeira 3 semanas ocorre espontaneamente. Abortos espontâneos esporádicos e recorrentes são os dois problemas ginecológicos mais comuns. É difícil estabelecer a freqüência de abortos precoces, porque, frequentemente, ocorrem antes que a mulher saiba que está grávida. Um aborto que ocorra vários dias após a primeira ausência da menstruação é, provavelmente, confundido com o atraso da menstruação. A detecção do concepto na menstruação é muito difícil por causa de seu tamanho reduzido. Os estudos da maioria dos abortos espontâneos iniciais resultantes de problemas médicos revelam conceptos anormais. Mais de 50\% dos abortos espontâneos conhecidos resultam de anormalidades cromossômicas. A maior incidência de abortos precoces de mulheres mais velhas provavelmente resulta do aumento da freqüência da não-disjunção durante a ovogênese. Foi estimado que de $30 \%$ a $50 \%$ de todos os zigotos nunca se desenvolvem em blastocistos nem se implantam. A não-implantação do blastocisto pode resultar de um endométrio pouco desenvolvido; entretanto, em muitos casos, há, provavelmente, uma anormalidade cromossômica letal no embrião que causa o aborto. Existe maior incidência de abortos espontâneos em fetos com defeitos do tubo neural, fenda labial e fenda palatina". As gravidezes ectópicas, por seu turno, são aquelas em que o blastocisto se implanta fora do útero.

${ }^{340}$ Ibid., p. 2 .

${ }^{341}$ Ibid., p. 2 .
} 
Para muitos autores, a nidação poderia ser considerada um marco biológico para a vida humana individuada, que representaria o sentido ativo da concepção, uma vez que envolve o papel da mãe em acolher o embrião. Representa a implantação do óvulo fecundado no útero, etapa inicial da conexão entre a mulher e o novo ser biológico que começa a se formar.

Norman M. Ford entende que a individualização, que poderia ser considerado o marco relevante acerca da vida biológica humana, é o aparecimento da linha embrionária primitiva, o que ocorre somente após o final da implantação do embrião no endométrio materno.

Essa linha embrionária primitiva é o resultado da convergência das células do epiblasto na parte posterior do disco embrionário. É um fator-chave para diferenciação que ocorrerá a partir desse ponto, podendo ser notada, inclusive, a simetria bilateral. Pode-se dizer, segundo Ford, que a partir daí existe um ser humano em sentido ontológico, muito além da mera individualidade genética, presente ao final da fertilização ${ }^{342}$.

Há ainda autores que falam no início da vida considerando o aspecto biológico a partir do momento em que ocorrem os primeiros movimentos espontâneos, quando se tem uma estrutura cerebral completa, o início das atividades neurais, a resposta a estímulos, o

\footnotetext{
${ }^{342}$ FORD , Norman M. When did I begin?: conception of the human individual in history, philosophy and science. Cambridge: Cambridge University, 1988, pp. 171-172. Como escreve Ford, "o aparecimento da linha primitiva é um marco importante, indicando a posição do embrião com as principais características do novo plano corporal individual. Este parece ser o estágio de desenvolvimento em que as células do epiblasto pela primeira vez se tornam organizadas através dessa linha primitiva num ser humano individualizado vivo completo e multicelular, possuindo pela primeira vez um eixo bilateral simétrico. As suas células em desenvolvimento são agora integradas e subordinadas para formar um corpo orgânico heterogêneo único que perdura com sua individualidade ontológica e biológica pelas etapas subsequentes de crescimento de desenvolvimento. Um novo indivíduo humano começa quando a matéria das células do epiblasto se torna um corpo vivo, informado e atuado por uma forma humana, um princípio de vida ou alma que surge pelo poder criador de Deus. A aparência da linha primitiva sinaliza que somente um embrião propriamente e indivíduo humano se formou e começou a existir. Antes deste estágio seria despropositado falar na presença de um verdadeiro ser humano em sentido ontológico. Um indivíduo humano poderia raramente existir antes de um corpo humano definitivo formado. Como mencionado antes, a formação de um indivíduo com uma natureza verdadeira humana e alma racional devem coincidir" (tradução nossa). No original: "the appearance of the primitive streak is an important landmark, indicating the position of the embryo proper with the main features of the new individual's body plan. This appears to be the stage of development when the cells of the epiblast first become organized through this primitive streak into one whole multicellular individual living human being, possessing for the first time a body axis and bilateral symmetry. Its developing cells are now integrated and subordinated to form a single heterogeneous organic body that endures with its own ontological as well as biological identity through all its subsequent stages of growth and development. A new human individual begins once the matter of the epiblastic cells become one living body, informed or actuated by a human form, life-principle or soul that arises through the creative power of God. The appearance of one primitive streaks signals that only one embryo proper and human individual has been formed and begun to exist. Prior to this stage it would be pointless to speak about the presence of a true human being in an ontological sense. A human individual could scarcely exist before a definitive human body formed. As mentioned earlier, the formation of an individual with a truly human nature and rational ensoulment must coincide".
} 
aparecimento da notocorda, o início dos batimentos cardíacos, a aparência humana (nesse caso, a biologia comparada de inúmeros embriões mostra que até determinado estágio do desenvolvimento, as semelhanças entre cada embrião são muito grandes, de modo a não ser possível dizer, observando-os, qual pertence a determinada espécie) $)^{343}$.

Por outro lado, há quem entenda que a tarefa de delimitar quando começa a vida pode estar inexoravelmente fadada ao fracasso. Como assevera Marco Segre,

ninguém pode definir que a vida se inicia tão-somente no encontro dos gametas, e não antes, ou depois, como por exemplo, quando se inicia a pulsação do coração fetal, ou quando o tecido encefálico já permite, ao feto, sentir dor. Não se pode precisar o instante o início da vida, sendo ela um processo progressivo, que não surge ou se extingue de uma só vez. Quando se apela à ciência para demarcar o início da vida, o que se faz é uma utilização 'religiosa' da observação científica, que apenas pode indicar o momento da 'mistura dos DNAs, ${ }^{344}$.

Deveras, delimitar o início da vida pode ser tarefa demasiadamente complicada. Porém, podemos considerar os dados empíricos que a observação do desenvolvimento embrionário nos fornece e interpretar cada uma das etapas. É o que fez Ford. Afinal, é de se considerar que mesmo nas células gaméticas já haja vida e, ainda em outras células diploides de nosso corpo. Vida humana, indiscutivelmente. Mas em nenhum desses casos, vida humana individuada. Esta aparece algum tempo depois da fecundação, após a implantação do zigoto no útero. Assim, para além da mistura de DNAs, podemos vislumbrar quando há a individualização do conjunto de células originado pelas divisões celulares e o surgimento do ser ontológico. Assim, se a ciência biológica não fornece respostas a priori, caberá às ciências do espírito a análise dos fatos e sua interpretação.

Essa é a razão pela qual Alison M. Jaggar diz ser necessário indagar: qual a relação lógica dos fatos com o argumento em questão? Os fatos são suficientemente relevantes

${ }^{343}$ DARWIN, Charles. A origem das espécies. São Paulo: Folha de São Paulo, 2010, p. 317. Sobre as constatações de sua pesquisa e teoria, Darwin escreve: "Já observamos que diversas partes de um mesmo indivíduo, que são identicamente semelhantes durante o primeiro período embrionário, se diferenciam notavelmente no estado adulto e servem então para usos muito diferentes. Temos demonstrado, com efeito, que os embriões das espécies mais distintas pertencendo a uma mesma classe são geralmente muito semelhantes, mas, desenvolvendo-se, tornam-se muito diferentes"

${ }^{344}$ SEGRE, Marco. Limites éticos da intervenção sobre o ser humano. In: COHEN, Cláudio (org). Bioética. São Paulo: Edusp, 1999, p.103. 
para funcionar como evidência? Quão completa é a evidência relativa ao argumento em foco? Outra evidência pode mudar a conclusão? $?^{345}$

Porém, mesmo se houvesse a possibilidade de se fixar um marco para o início da vida individuada, permanece a indagação: isto é suficiente para que o Direito tome em consideração somente a vida biológica para regulação do comportamento e das atividades humanas?

Não consideramos suficiente que o genético e o ontológico - no sentido acima fixado - possam fundamentar o Direito, de modo que a vida biológica seja o núcleo determinante. A questão moral do aborto não se restringe à vida humana. Assim, o início da vida - e mesmo o apego à vida biológica, de um ser pertencente à espécie Homo sapiens - não parece um referencial seguro (ou suficiente) para as decisões sobre a interrupção da gravidez. Soa estranha a assertiva, mas não é um organismo que possui direitos - e isto será aprofundado e fundamentado no capítulo seguinte.

É mister analisar, no próximo tópico, as concepções autopoiética e biossemiótica sobre o início da vida humana, a que pouco se tem feito referência, mas que representam formulações interessantes sobre o fenômeno da vida, como sistema ou linguagem.

\subsubsection{Concepções biossemiótica e autopoiética sobre o início da vida}

A vida é um fenômeno complexo e de difícil definição. Como podemos perceber, somente na seara biológica, há uma infinidade de posições acerca do marco inicial do ser biológico.

No entanto, há quem analise os seres vivos, e a vida de um modo geral, de maneira distinta das formas comumente sublinhadas em Bioética. Daí a relevância em destacar, ainda que brevemente, esse enfoque inovador apresentado por Humberto R. Maturana e Francisco J. Varela, especialmente assentados no livro intitulado A Árvore do

\section{Conhecimento.}

\footnotetext{
${ }^{345}$ TOOLEY, Michael; WOLF-DEVINE, Célia; DEVINE, Philip E.; JAGGAR, Alison M. Abortion: three perspectives. New York: Oxford, 2009, p.225. "Os fatos funcionam como evidência somente quando são relevantes para determinados assuntos em particular e seu peso depende de outra relevante informação. Se os fatos são relevantes ou completos é uma questão de avaliação lógica e normativa e não de uma verdade empírica" (tradução nossa). No original: "Facts function as evidence only when they are relevant to particular claims and their weight depends on other relevant information. Whether facts are relevant or complete is a matter of logical and normative assessment rather than empirical truth. In constructing moral arguments, therefore, how facts are selected, interpreted and linked with desired conclusions is just as important as their empirical accuracy".
} 
Podemos mencionar uma das indagações iniciais realizadas pelos autores concernente à distinção entre os seres vivos e todo o resto que não seja dotado de "vida". Afinal, o que faz de um ser um ser vivo? Na Filosofia da ciência biológica, os debates em torno do que seria a vida são encontrados com frequência. Ora, para saber quando começa a vida, é necessário antes que esta seja definida, por razões lógicas.

Nessa trilha, como indagam Maturana e Varela,

como saber quando um ser é vivo? Quais são os critérios? Ao longo da história da biologia, foram propostos muitos critérios e todos eles apresentaram dificuldades. Por exemplo, alguns propuseram que o critério fosse a composição química. Ou a capacidade de movimento. Ou, ainda, a reprodução. Ou, por fim, alguma combinação desses critérios, ou seja, uma lista de propriedades. Porém, quando saber quando a lista está completa? Por exemplo, se construirmos uma máquina capaz de reproduzir - mas que é feita de ferro e plástico, não de moléculas orgânicas - , podemos dizer que ela está viva? ${ }^{346}$.

O sonho da criação humana; saber o que seja a vida, e talvez criá-la, fascina o homem e o instiga a uma forma de autodomínio. Contudo, o conhecimento da própria Biologia mostra barreiras insondáveis, de maneira a impossibilitar que se alcance a fórmula da vida.

Maturana e Varela pressupõem, para determinação do que seja vivo, que haja nos seres vivos uma forma de organização. Mas uma organização específica, que denominam de autopoética. Os seres vivos, nesse sentido, são capazes de produzirem, de modo contínuo, a si próprios, sendo que as relações podem ser apreendidas já a nível celular, caracterizando-se por uma "rede contínua de interações",347.

O termo autopoiético, nesse contexto, significa uma autoprodução, uma autorreferência dos sistemas vivos, de maneira que não se torna possível separar o produto do produtor. Assim,

o que lhes é peculiar é que sua organização é tal que seu único produto são eles mesmos. Donde se conclui que não há separação entre produtor e produto. O ser

\footnotetext{
${ }^{346}$ MATURANA, Humberto R.; VARELA, Francisco R. A árvore do conhecimento: as bases biológicas da compreensão humana. São Paulo: Palas Athena, 2001, pp.48-49.

${ }^{347}$ Ibid., p. 52.
} 
e o fazer de uma unidade autopoiética são inseparáveis, e isso constitui seu modo específico de organização ${ }^{348}$.

Analisando a teoria de Humberto Maturana e Francisco Varela, destacam Claus Emmeche e Charbel Nino El-Hani que

a rede de vias e componentes metabólicos dentro de uma célula é um ponto de partida para a compreensão de uma definição de vida, que é parte de um paradigma da biologia teórica, a teoria da autopoiese, que não tem (ao menos no presente) o papel central da síntese neodarwinista no pensamento biológico, mas orienta a investigação de um número significativo de pesquisadores em todo o mundo e em variados ramos da ciência ${ }^{349}$.

Além disso, nota-se uma arquitetura sofisticada, que delimita uma fronteira de relações - daí ser corroborada a ideia de sistema autopoiético. A fronteira pode ser relacionada à membrana, e o conjunto de acontecimentos, à dinâmica da vida, de metabolismo.

Como explicam os autores, os dois aspectos que formam uma unidade, dinâmica e fronteira, são inseparáveis e "a característica mais peculiar de um sistema autopoiético é que ele se levanta por seus próprios cordões, e se constitui como diferente do meio por sua própria dinâmica, de tal maneira que ambas as coisas são inseparáveis”350.

Assim, percebe-se, na obra dos autores, uma preocupação quanto à compreensão dos fenômenos biológicos não estritamente em termos descritivos do suceder de acontecimentos. É notável a atribuição de um sentido àquilo que se desenrola, firmando-se uma interpretação filosófica da vida, que adquire um sentido completamente novo como fenômeno.

Conceber uma organização sistemática não se limita à enumeração de propriedades dos sistemas vivos em detrimento de um universo de coisas sem vida. Ao contrário, buscase um sentido interacional, de intercâmbio entre os componentes de uma unidade viva.

\footnotetext{
${ }^{348}$ Ibid., p. 57.

${ }^{349}$ EMMECHE, Claus; EL-HANI, Charbel Niño. Definindo vida. In: EL-HANI, Charbel Niño; VIDEIRA, Antonio Augusto Passos. O que é vida: para entender a Biologia do século XXI. Rio de Janeiro: Relume Dumará, 2005, pp.45-46.

${ }^{350}$ MATURANA, Humberto R.; VARELA, Francisco R. A árvore do conhecimento: as bases biológicas da compreensão humana. São Paulo: Palas Athena, 2001, pp. 54-55.
} 
Mas o que diferenciaria um organismo vivo de outros sistemas, que possuem também uma unidade? O fato de constituírem um sistema autopoiético, explicam os autores. Ademais, a autonomia é uma marca dos seres vivos. Nesse sentido,

perceber os seres vivos como unidades autônomas permite mostrar como sua autonomia - em geral vista como algo misterioso e esquivo - se torna explícita ao indicar que aquilo que os define como unidades é a sua organização autopoiética, e que é nela que eles, ao mesmo tempo, realizam e especificam a si próprios ${ }^{351}$.

A compreensão desse modelo de sistemas vivos conduz, por conseguinte, ao destaque do fenômeno marcado pela interação, que ocorre já a nível celular nos sistemas vivos entre as moléculas que o compõem. Além disso, as interações entre os componentes do sistema vivo são constantes.

Exsurge, em comparação, a ideia de seres vivos como se fossem máquinas autopoiéticas. "O que diferencia, nessa teoria, as máquinas orgânicas das máquinas construídas pelo homem é o fato de que essas últimas não geram por si mesmas seus constituintes e, portanto, não podem ser consideradas autopoiéticas" 352 .

Podemos ainda aventar a existência de regras que regem essas interações. Salientam os autores, exemplificando a fenomenologia biológica, que

se uma célula interage com uma molécula $X$, incorporando-a a seus processos, o que acontece como conseqüência da interação não está determinado pelas propriedades dessa molécula, e sim pela maneira como ela é "vista" ou tomada pela célula, ao incorporá-la à sua dinâmica autopoiética. As mudanças que possam ocorrer nela, em consequiência dessa interação, serão as determinadas por sua própria estrutura como unidade celular. Portanto, na medida em que a organização autopoiética determina a fenomenologia biológica - ao configurar os seres vivos como unidades autônomas -, será chamado de biológico todo fenômeno que implique a autopoiese de pelo menos um ser vivo ${ }^{353}$.

\footnotetext{
${ }^{351}$ Ibid., p. 56.

${ }^{352}$ EMMECHE, Claus; EL-HANI, Charbel Niño. Definindo vida. In: EL-HANI, Charbel Niño; VIDEIRA, Antonio Augusto Passos. O que é vida?: para entender a Biologia do século XXI. Rio de Janeiro: Relume Dumará, 2005, p.47.

${ }^{353}$ MATURANA, Humberto R.; VARELA, Francisco R. A árvore do conhecimento: as bases biológicas da compreensão humana. São Paulo: Palas Athena, 2001, p. 61.
} 
Este enfoque das teorias de Maturana e Varela lembra a abertura da obra de Clarice Lispector, A hora da estrela, que trazemos à colação. A possibilidade de diálogo entre as formas de conhecimento e manifestações artísticas já foi acentuada nos capítulos iniciais, em que se expôs as específicas relações entre o Cinema e o Direito - e retomado no capítulo segundo. Também quanto à Literatura, essa interação mostra-se possível, de maneira logopática.

Pois bem. No inicio do romance de Clarice Lispector, lê-se que "tudo no mundo começou com um sim. Uma molécula disse sim a outra molécula e nasceu a vida".

Assim, consideramos possível a comparação, pois, em verdade, os elementos biológicos, em sistemas autopoiéticos, estão em constante intercâmbio.

A ideia trazida por Clarice, entendemos, refere-se à origem da vida em geral, o que se depreende da constatação posterior, que segue à frase transcrita: "Mas antes da préhistória havia a pré-história da pré-história e havia o nunca e havia o sim. Sempre houve. Não sei o quê, mas sei que o universo jamais começou" ${ }^{354}$. Porém, o sentido de vida que se depreende da parte inicial pode ser compreendido, também, em termos de origem da vida. E origem de maneira comunicacional, que supõe uma forma especial de interação.

Poderia a origem da vida ser considerada episódica, um ponto definido que pode ser visto pela pesquisa biológica, pela análise num microscópio dos acontecimentos que envolvem a definição de vida biológica? Ou, ao contrário de um ponto isolado, a vida pode ser compreendida como um verdadeiro processo, em que inúmeras etapas estão presentes, sendo a interpretação do resultado final denominado de vida, sem que, no entanto, qualquer dos pontos desse processo possa ser considerado, independentemente, como crucial para o início?

A intenção humana de estabelecer limites para todas as coisas tem a pretensão de entendimento total, de tomar um fenômeno ou um objeto em todas as suas facetas. Mas as convenções sobre o início e o fim da vida, apesar de critérios práticos para o estudo, são critérios arbitrários, longe de constituirem verdades imutáveis. Ora, mesmo os fenômenos biológicos, ou leis biológicas, podem mudar com o desenvolvimento de técnicas que desvendam com mais proficuidade o objeto do conhecimento tomado.

E um sistema interativo, tal como verificado em Maturana e Varela, permite que o início da vida seja compreendido como um ponto fixo, um episódio apreensível com uma razão cartesiana?

\footnotetext{
${ }^{354}$ LISPECTOR, Clarice. A hora da estrela. Rio de Janeiro: Rocco, 1998, p. 11. Ambos os trechos.
} 
Nesse passo, salientam Claus Emmeche e Charbel Nuno El-Hani que

\begin{abstract}
a autopoiese é uma propriedade do tipo tudo-ou-nada; um sistema não pode ser "mais ou menos" autopoiético. A origem da autopoiese não pode, portanto, ser um processo gradual. Não há lugar, na teoria de Maturana e Varela. Para sistemas em transição de um mundo não-vivo (não-autopoiético) para um mundo vivo (autopoiético); no momento em que a vida se originou na Terra, houve uma mudança qualitativa, de um tipo de existência não-autopoiética (o mundo químico) para um tipo de existência autopoiética (o mundo vivo) ${ }^{355}$.
\end{abstract}

Contextualizando a obra de Maturana e Varela, entendem os autores que

\begin{abstract}
a dinâmica de qualquer sistema no presente pode ser explicada mostrando as relações entre suas partes e as regularidades de suas interações, de modo a fazer com que sua organização se torne evidente. Porém, para que possamos compreender isso de modo cabal, o que queremos não é vê-lo como uma unidade funcionando em sua dinâmica interna, mas também em sua circunstância, no entorno ou contexto com o qual seu funcionamento o conecta (...) contudo, a situação não é simples quando se trata de seres vivos, porque sua gênese e história jamais nos são diretamente visíveis e só podem ser reconstruídas de modo fragmentário ${ }^{356}$.
\end{abstract}

Apresentada a ideia de sistemas autopoiéticos, faz-se a diferenciação entre organismos unicelulares e pluricelulares. Afinal, como se dá a interação em sistemas formados por milhares de unidades, as células, de maneira que seja mantida uma unidade do ser vivo?

Introduz-se, pois, a noção de ontogenia, entendida como a "história de mudanças estruturais de uma unidade, sem que esta perca a sua organização, ${ }^{, 357}$. Essas transformações compreendem interações internas e com o meio, como no caso das células. Em organismos multicelulares, há uma complexidade maior, como notamos pouco acima, e, além das mudanças internas, das relações que passam a ocorrer entre célula e meio, terse-á, porventura, relações entre as unidades autopoiéticas.

${ }^{355}$ EMMECHE, Claus; EL-HANI, Charbel Niño. Definindo vida. In: EL-HANI, Charbel Niño; VIDEIRA, Antonio Augusto Passos. O que é vida?: para entender a Biologia do século XXI. Rio de Janeiro: Relume Dumará, 2005, p.47.

${ }^{356}$ MATURANA, Humberto R.; VARELA, Francisco R. A árvore do conhecimento: as bases biológicas da compreensão humana. São Paulo: Palas Athena, 2001, p. 68.

${ }^{357}$ Ibid., p. 86. 
Quando ocorre uma tal relação entre as células, de modo dinâmico e duradouro, acontece o que Maturana e Varela denominam de acoplamento estrutural. Escrevem que "duas (ou mais) unidades autopoiéticas podem estar acopladas em sua ontogenia, quando suas interações adquirem um caráter recorrente ou muito estável”. E, complementam os autores,

o acoplamento estrutural com o meio como condição de existência, abrange todas as dimensões das interações celulares e, portanto, também as que têm a ver com outras células. As células dos sistemas multicelulares normalmente existem em estreita junção com outras células, como meio de realização de sua autopoiese. Tais sistemas são o resultado da deriva natural de linhagens nas quais se manteve essa junção ${ }^{358}$.

Nesse passo, vale destacar que Goffredo Telles Júnior também faz incursões nos ramos da Química, Física e Biologia, inter-relacionando os fenômenos do mundo natural ao Direito, objeto cultural. Sua visão, que parte desde a formação do universo até a constituição da biologia humana ${ }^{359}$, pode ser relacionada, em parte, aos escritos de Maturana e Varela.

De fato o jurista, ao estudar as células, fala em relações de comando que estariam presentes desde as organizações iniciais da matéria, o que não deixa de supor uma interação entre os elementos componentes.

Após indicar a perplexidade dos estudiosos da Biologia sobre uma definição do que seja a vida, acaba por relacioná-la à existência de operações de comando que, segundo o autor, compreendem:

1. a transmissão, ao ácido nucleico, de uma informação sobre um acontecimento atual, que afeta a célula; 2. a confrontação dessa informação com a memória do ácido nucleico; 3. a reação conseqüente do ácido nucleico, determinando uma reorganização interna da matéria celular, com produção dos meios necessários para a salvaguarda e conservação da própria célula (...) a entidade capaz de executar uma tal operação executa, igualmente, a de transmitir, a seus descendentes, um sistema de comando ${ }^{360}$.

\footnotetext{
${ }^{358}$ Ibid., pp. 87-89.

359 TELLES Júnior. Goffredo. O Direito Quântico: ensaio sobre o fundamento da ordem jurídica. São Paulo: Max Limonad. Mas, além dessa obra, vale destacar a obra Estudos, do jusfilósofo.

${ }^{360}$ Ibid., pp.109-110.
} 
Há, tanto numa obra como n'outra a alusão a interações, que ocorrem entre os elementos mínimos presentes numa unidade celular. A vida, assim, pode ser considerada um fenômeno amplo, complexo, ligado a transformações, mudanças, comunicação, interação, informações e comandos.

Uma dúvida surge e se põe na questão de os organismos metacelulares constituírem, em seu todo, um sistema autopoiético. Ou seja, compreendido o fato de que as células componentes de um organismo representarem uma organização autopoiética que se autoproduz, sendo autorreferencial, e que pode estabelecer relações entre o meio, como as trocas que ocorrem através da membrana celular, e talvez até com outras células do corpo de um ser vivente, interessa saber se a totalidade formada através do acoplamento estrutural das células poderia ser considerada também uma forma de organização autopoiética.

A questão não apresenta uma solução definida, e diz respeito à possibilidade de configuração de sistemas autopoiéticos de segunda ordem.

Para Maturana e Varela, a questão é aberta, e pode-se dizer "que eles têm uma clausura operacional em sua organização: sua identidade está especificada por uma rede de processos dinâmicos, cujos efeitos não saem dessa rede ${ }^{, 361}$.

Entendemos que, analogicamente, essas interações reproduzem-se em todos os escalões da Biologia: nas células, compreende os fenômenos interativos que determinam caracteres do indivíduo; há uma especialização de funções, de maneira que, apesar de constituírem unidades autopoiéticas, relacionam-se com o meio e as células ao redor.

Os organismos biológicos como um todo poderiam ser vistos como sistemas autopoiéticos de segunda ordem, ainda que de maneira comparativa às interações celulares, marcadas por intercâmbio. De um modo ainda mais amplo, as pessoas comporiam um sistema social, com destaque às interações presentes entre os indivíduos. Metaforicamente, faz sentido falar, portanto, em um verdadeiro corpo social, que poderá ser ordenado por determinado sistema jurídico.

Assim, interessa trazer à colação os ensinamentos de Goffredo, segundo o qual

o primeiro fundamento das tábuas morais, dos sistemas axiológicos de referência, dos usos e costumes, das ordenações jurídicas se encontra nos

\footnotetext{
${ }^{361}$ MATURANA, Humberto R.; VARELA, Francisco R. A árvore do conhecimento: as bases biológicas da compreensão humana. São Paulo: Palas Athena, 2001, pp. 99-101.
} 
elementos quânticos, de que se compõem as moléculas do ácido nucléico, no núcleo das células humanas ${ }^{362}$.

Ora, impende destacar que todo o universo se rege por leis e não seria diferente entre as partículas componentes das células e as unidades que constituem cada organismo vivo. E é nessa ideia de relação, já é estabelecida entre as menores unidades, que pode ser situada, também, a noção de ordenação de estruturas.

Cada parte que compõe o organismo possui um determinado papel, uma função delimitada e uma complexidade crescente, o que ensejou o surgimento da linguagem. Como escreve Goffredo, dessa ordem de ideias, que culmina num sistema jurídico interacional, pode-se concluir que

o Direito Objetivo é a ordenação de determinadas espécies de interações humanas. É a ordenação que quantifica a liberação das energias humanas, para assegurar o equilíbrio das forças, e para garantir que, a cada direito, corresponda uma obrigação. É a ordenação que delimita a liberação da energia, nos campos dos homens, para que a sociedade seja efetivamente o que ela precisa ser, isto é, um meio a serviço dos fins humanos (...) o Direito é a ordenação quântica das sociedades humanas $^{363}$.

A pessoa é um ser eminentemente comunicativo - o que pode ser tomado como um verdadeiro reflexo de interações que ocorrem em níveis intracelulares. No entanto, é patente a dificuldade de determinação do início da vida, mesmo levando em consideração uma perspectiva autopoiética, que ultrapassa a mera observação de fenômenos biológicos para constituir uma forma de interpretação daquilo que se chama de sistemas vivos.

Vale dizer ainda que, de acordo com a teoria de Maturana e Varela, os sistemas autopoiéticos, apesar de interação entre os seus elementos constituintes, são fechados (daí se falar em fechamento operacional do sistema autopoiético $)^{364}$.

\footnotetext{
362 TELLES Júnior. Goffredo. O Direito Quântico: ensaio sobre o fundamento da ordem jurídica. São Paulo: Max Limonad, p. 246.

${ }^{363}$ Ibid., p. 285.

${ }^{364}$ EMMECHE, Claus; EL-HANI, Charbel Niño. Definindo vida. In: EL-HANI, Charbel Niño; VIDEIRA, Antonio Augusto Passos. O que é vida?: para entender a Biologia do século XXI. Rio de Janeiro: Relume Dumará, 2005, p.46. Escrevem os autores que a referida teoria "põe em destaque a idéia de que os sistemas autopoiéticos só podem ser caracterizados com referência a si mesmos, ou seja, de que um sistema vivo, como uma rede fechada de relações, pode ser visto como uma organização que define a si própria, o que ilumina um aspecto auto-referencial da vida que não é observado na definição da biologia evolutiva neodarwinista".
} 
Um outro modelo interessante de compreensão da vida é o denominado biossemiótico, que pela sua novidade merece destaque nesse item, ainda que em breves palavras.

É inegável que há uma ligação dos modelos da Biologia com as teorias da linguagem. Assim, pode-se dizer que

\begin{abstract}
a biossemiótica é um paradigma novo da biologia teórica que procura propiciar uma maneira de perceber a vida que não seja baseada apenas na organização das moléculas, mas também na comunicação de signos na natureza (...) O que a biossemiótica propõe é uma maneira de entender a vida biológica como um fenômeno que é, desde sua origem, semiótico; a produção, transmissão e interpretação dos signos não teriam surgido, dessa maneira, apenas com a espécie humana, mas estariam aqui desde a origem da vida. A natureza, para a biossemiótica, está cheia de signos $^{365}$.
\end{abstract}

Assim verificamos uma aplicação de modelos linguísticos à realidade biológica perspectiva interdisciplinar de compreensão de uma realidade fenomênica. Vale dizer que a vida passa a ser compreendida sob um outro ângulo, em que entram em cena as ideias de signo e significado.

Sem dúvida, trata-se de um modelo mais complexo de intelecção do início da vida, e da própria interpretação das formas vivas, o que significa uma proposta de reflexão das teorias comumente presentes nos livros que se propõem a delimitar o início da vida a partir da concepção. De outro modo, a própria ideia de vida pode ser articulada em termos linguísticos. Com isso, fica patente a impossibilidade de definição da vida em termos absolutos, pois o substrato biológico não é simplesmente um dado, mas um dado interpretável.

Este viés biossemiótico qualifica-se através de uma série de expressões, termos relacionados a mensagens e informações. Assim, é comum encontrarmos nas ciências biológicas noções como as de "informação genética", "código genético", "sinais moleculares". Além do mais, os fenômenos biológicos poderiam ser considerados semióticos, dado que sua descrição usualmente envolve ideias como as de codificação, processamento de informação, intercâmbio e interpretação de sinais ${ }^{366}$.

\footnotetext{
${ }^{365}$ Ibid., p.48.

${ }^{366}$ Ibid., pp. 48-49. Como lembram os autores, "há autores que criticam o uso do conceito de informação na biologia, destacando que, uma vez que não há uma noção de informação claramente formulada nessa ciência, esse conceito não passa de uma metáfora estranha à biologia, cuja utilização poderia conduzir a uma visão
} 
Mas nenhuma teoria é imune a críticas, sob pena de tornar-se absoluta e inquestionável - o que repudiamos. Da mesma maneira, a teoria biossemiótica sofre investidas, a começar pelo problema de separação entre o dado natural e o dado cultural. Ora, a compreensão biossemiótica da vida parte de signos; mas como estes poderiam estar presentes na natureza independentemente da cultura humana?

Assim, escrevem Claus Emmeche e Charbel Nino El-Hani que

para preencher a lacuna entre a natureza (física) e a cultura (semiótica), é preciso desenvolver uma teoria capaz de explicar a geração como parte da atividade natural de sistemas físicos, do chamado significado original (Haugeland, 1985), e não apenas do significado atribuído pelo observador. Um dos problemas mais sérios com que se defronta a biossemiótica é, exatamente, o de que não há ainda descrições convincentes do surgimento de signos em sistemas puramente físicos 367 .

De fato, como declaramos há pouco, vemos nessa teoria uma interpretação de fenômenos e dados físicos. A própria utilização de termos da linguística já deixa isto bem claro. Tudo que se qualificar como vida do ponto de vista biossemiótico passará pelo crivo de um intérprete.

Assim, de acordo com os biossemioticistas,

a vida pode ser definida (...) como interpretação funcional dos signos em sistemas materiais auto-organizados (Emmeche, 1998); ou, dito de outra maneira, como uma propriedade de sistemas materiais auto-organizados capazes de utilizar informação de maneira a realizar funções que favoreça, sua adaptação e sobrevivência $^{368}$.

Para estruturação da teoria biossemiótica, os autores recorrem a teóricos da linguagem, entre os quais, Charles Sanders Peirce, remetendo à estruturação de um triângulo semiótico, composto por veículo do signo, objeto e significado.

errônea da explicação em campos como a biologia molecular (Stuart, 1985; Sarkar, 1996). Desse modo, seria mais apropriado deixar de lado a 'linguagem' da informação. Os biossemioticistas discordam dessa posição, afirmando que o uso de conceitos e teorias da semiótica na interpretação da 'linguagem' da informação biológica contribuiria exatamente para sua formulação de maneira precisa e consistente, conduzindo a biologia a uma nova visão de seu objeto de estudo, que poderia ser capaz até mesmo de revolucioná-la".

${ }^{367}$ Ibid., p. 50.

${ }^{368}$ Ibid., p. 50. 
Para este estudo, importam apenas algumas ideias que têm correlação com o tema pesquisado, de maneira que não serão aprofundados os pormenores linguísticos existentes na obra de Peirce, que aborda uma série de tricotomias de signos, especificando vários tipos de relação triádica existentes, explicitando ainda uma tipologia de signos. Assim, a referência à obra do autor é modesta, e remetemos o leitor aos estudos de Peirce para aprofundamentos. Vale esclarecer que este trabalho não requer uma compreensão profunda da teoria do autor citado.

Isto posto, vale dizer que, nas palavras esclarecedoras de Charles Sanders Peirce,

um signo, ou representamen, é aquilo que, sob certo aspecto ou modo, representa algo para alguém. Dirige-se a alguém, isto é, cria, na mente dessa pessoa, um signo equivalente, ou talvez um signo mais desenvolvido. Ao signo assim criado denomino interpretante do primeiro signo. O signo representa alguma coisa, seu objeto. Representa esse objeto não em todos os seus aspectos, mas com referência a um tipo de idéia que eu, por vezes, denominei por fundamento do representamen ${ }^{369}$.

Além disso, Peirce destaca em seus escritos que entre o representamen, o objeto e o interpretante estrutura-se uma relação genuinamente triádica, e não diática entre cada componente semiótico $^{370}$.

Considerando a abordagem trazida por Claus Emmeche e Charbel Nino El-Hani, com suporte na teorização de Peirce, tem-se que o veículo do signo é denominado de representamen, o objeto é também chamado de referente, e o significado, de interpretante, de maneira que a relação entre o representamen (veículo do signo) e o referente é apenas indireta. Destacam os autores, esclarecendo a teoria, que

do ponto de vista da biossemiótica, a propriedade do veículo do signo de representar alguma outra coisa, fazendo com que se estabeleça uma relação triádica na qual o significado (o interpretante) estabelece uma ligação entre esse veículo (o representamen) e o objeto do signo, é o que permite que os sistemas vivos funcionem como intérpretes de signos e, desse modo, respondam de maneira adequada, adaptativa, à informação disponível em seus ambientes ${ }^{371}$.

${ }^{369}$ PEIRCE, Charles Sanders. Semiótica. São Paulo: Perspectiva, 1977, p. 46.

${ }^{370}$ Ibid., p. 63.

${ }^{371}$ EMMECHE, Claus; EL-HANI, Charbel Niño. . Definindo vida. In: EL-HANI, Charbel Niño; VIDEIRA, Antonio Augusto Passos. O que é vida?: para entender a Biologia do século XXI. Rio de Janeiro: Relume Dumará, 2005, pp.50-51. 
Para exemplificar, pode ser tomado o próprio exemplo trazido pelos autores. A escrita em um papel da palavra "vida", a tinta, é ilustrativa. No caso, tem-se que a tinta serve de veículo (representamen) da palavra (objeto ou referente). Conforme a cultura, a pessoa que leia, ou o lugar em que a palavra foi escrita, será formada uma representação mental, que é o significado (interpretante).

A teoria, nesse sentido, teria aplicação a sistemas biológicos, como ocorre com os mecanismos de defesa dentro do organismo, de maneira que a resposta imunológica estaria relacionada às mensagens recebidas pelos corpos presentes dentro do ser, e a resposta, às moléculas estranhas a partir da interpretação dos objetos.

No entanto, pode-se dizer que - quer de um ponto de vista estritamente biológico, quer do ponto de vista de uma interpretação que tome por substrato os acontecimentos que ocorrem entre células e componentes intracelulares, no feto, ou mesmo no zigoto humano -, após a concepção, já existe o que se pode denominar de vida.

Enfim, vimos até agora inúmeros enfoques que podem ser tomados para definição de vida, seja em termos estritamente biológicos, seja em termos predominantemente linguísticos, em que se destacam argumentos de outras áreas do saber (como a Linguística). Cada uma dessas teorias, por mais elaborada que seja, propicia uma só constatação: a incerteza de uma definição que possa ser tomada em termos absolutos, de maneira imune a críticas. Todas, mesmo as médico-científicas, são elaborações linguísticas. Assim, a ideia de vida em termos biossemióticos ou autopoiéticos poderá considerar a ligação mãe-feto um sistema vivo, ou uma composição que signifique vida humana a ser protegida em sentido absoluto. Mas, acima de tudo, não passarão de construções da linguagem, e não conceitos e delimitações precisas.

A questão problemática que se põe, e que celeumas bioéticos estão sempre às voltas, é saber se a vida humana, qualquer que seja a definição considerada, é suficiente para ser tomada como o critério das análises bioéticas.

Cuida-se de uma visão que considera um sentido sagrado da vida humana, e cujos argumentos merecem análise detida, a ser feita no tópico que segue. Afinal, quais as razões de considerar-se a vida sagrada e intangível? Quais os fundamentos que subjazem a sacralidade da vida humana? 


\subsection{A sacralidade da vida humana ${ }^{372}$}

A sacralidade da vida costuma soar como um dos argumentos absolutos que se impõem nos debates bioéticos. Pois a sacralidade enseja o respeito à vida, como um bem inviolável, considerado em primazia quando surge um conflito a ser resolvido ${ }^{373}$. Além disso, "a concepção de que a vida humana tem um valor único está profundamente enraizada em nossa sociedade e é cultuada pelo nosso Direito”374.

O aborto, portanto, significaria uma grande ofensa à vida humana, por ensejar o seu perecimento; a utilização de embriões para retirada de células-tronco, por levar à morte do embrião, também. Deveras, desde a concepção, a vida humana é considerada sacrossanta, sendo um grave erro a sua violação. Tem-se como suficiente para a proteção da vida o pertencimento do zigoto à espécie Homo sapiens. Mas o só fato de pertencer à espécie justificaria a intangibilidade da vida humana?

Para alguns autores, a resposta só pode ser negativa. Há, inclusive, quem realize um prognóstico de que a visão tradicional acerca da sacralidade da vida humana entrará em colapso, sob a pressão científica, tecnológica e demográfica ${ }^{375}$.

A discussão, no entanto, pode ser bem mais ampla e profunda, pois vários podem ser os fundamentos de se atribuir a alguma coisa um valor sagrado, de maneira que é equivocada a restrição do caráter sagrado de algo ao sentido religioso, como já pudemos observar no trabalho que desenvolvemos a título de Iniciação Científica.

Afinal, como poderíamos entender a ideia de sacralidade? Faz-se necessário retomar algumas noções que desenvolvemos por ocasião das leituras realizadas, pois

\footnotetext{
${ }^{372}$ Uma análise parelha, focada em Dworkin, é realizada por Jeff McMahan. Nesse sentido, cf.: A ética no ato de matar, Porto Alegre: Artmed, 2011, pp.346-355.

${ }^{373}$ YORK, Jon. The right to life and the value of life: orientations in law, politics and ethics. Great Britain: Ashgate, 2010. Jon York destaca entidades que preconizam a posição pró-vida, citando sites que expressam essas ideias, tais como International Right to Life Federation, www.internationalrigthtolife.com; Society for the Protection of Unborn Children, www.spuc.org.uk; Prolife America, www.prolifeamerica.com. Por outro lado, em defesa dos argumentos pró-escolha, destacam-se: Pro-Choice Majority, www.prochoicemajority.org.uk e Prochoice, http://prochoice.com.

${ }^{374}$ SINGER, Peter. Ética prática. São Paulo: Martins Fontes, 2002, p. 94.

375 SINGER, Peter. The sanctity of life. In: Foreign policy, set-out 2005. Disponível em: http://www.utilitarian.net/singer/by/200509--.htm; Acesso em: 9 de junho de 2006. Na opinião do autor, "Durante os próximos 35 anos, a visão tradicional da santidade da vida humana irá entrar em colapso sob a pressão dos desenvolvimentos científicos, tecnológicos e demográficos. Por volta de 2040, pode ser que somente um conjunto de extremistas e ignorantes religiosos fundamentalistas defenda a visão de que toda vida humana, da concepção à morte, é sacrossanta" (tradução nossa). No original: "During the next 35 years, the traditional view of the sanctity of human life will collapse under the pressure from scientific, technological, and demographic developments. By 2040, it may be that only a rump of hard-core, knownothing religious fundamentalists will defend the view that every human life, from conception to death, is sacrosanct".
} 
diferentes argumentos podem ser construídos, alicerçados nas noções de sagrado e interesse do feto. Daí decorrem duas concepções contrárias ao aborto, o que Dworkin nomeia como objeção derivativa e objeção independente, cada qual com seu embasamento lógico, o que, afinal, as distingue. ${ }^{376}$

Sistematizando esses argumentos, pode-se dizer que a objeção derivativa parte do pressuposto de que os fetos têm direitos e interesses. A responsabilidade do Estado ao proteger o feto, proibindo o aborto, seria derivativa justamente por derivar de uma constatação: fetos são pessoas. Por outro lado, a objeção independente não toma em seu corpo qualquer pressuposto. Seria errado abortar, pois se estaria a ferir a vida per se. Nessa concepção, a vida tem um valor inerente, independentemente de o feto ser pessoa. A sacralidade da vida já é suficiente para justificar a incriminação do aborto, que ofende, essencialmente, esse valor.

Destacamos que algo pode ser considerado valioso em si, sem que isso decorra de qualquer convicção necessariamente ligada ao divino. Seria algo lamentável, por exemplo, destruir uma obra de arte, como um quadro de Picasso, Salvador Dali etc. É inegável, o valor intrínseco dessas pinturas, e não se segue que isso seja devido a alguma concepção religiosa.

Nesse passo, na esteira de Ronald Dworkin, poderíamos considerar que algo pode ser valioso ou sagrado em três sentidos: intrínseca, instrumental ou subjetivamente.

Uma coisa terá valor intrínseco quando não depender de qualquer consideração por parte dos outros. Para Kant ${ }^{377}$, o homem é instrinsecamente valioso, não podendo ser usado

${ }^{376}$ DWORKIN, Ronald. Domínio da vida: aborto, eutanásia e liberdades públicas. São Paulo: Martins Fontes, 2003, pp.10-14. Conforme assevera o ilustre autor, "(....) a idéia de que o aborto é um pecado ou uma iniqüidade porque a vida humana é sagrada é muito diferente da afirmação de que é um pecado ou uma iniquiidade porque um feto tem o direito de viver."

377 SINGER, Peter. Rethinking life and death: the collapse of our traditional ethics. New York: St. Martin's Griffin, 1996, p. 168. Com Kant, destaca Singer, a ideia de centralidade e importância do homem alcança o desenvolvimento mais sofisticado, separando-se bruscamente animais e humanos, especialmente em função do papel desempenhado pela razão. "Na filosofia de Immanuel Kant, a visão ética centrada no humano alcançou seu desenvolvimento mais sofisticado. A visão de Kant é ainda reconhecidamente parte da tradição que de um lado retoma Aristóteles, e de outro a consistente doutrina cristã de que os seres humanos fazem parte tanto do mundo material como do mundo espiritual. De Aristóteles, Kant toma a ideia de que os animais 'são meramente meios para um fim. O fim é o homem'. Da doutrina cristã, Kant mantém a imagem dos seres humanos como divididos em dois mundos. Um era, como sempre, o mundo material, governado pelas leis da Física. O outro, entretanto, Kant apresentou numa forma Iluminista característica, como o mundo da razão. Isto porque os animais não podem raciocinar, e 'não são autoconscientes' que eles existem 'meramente como meios para um fim'. Humanos, por outro lado, como seres pensantes, autoconscientes e autônomos, devem ser respeitados como um fim em si mesmos" (tradução nossa). No original: "in the philosophy of Immanuel Kant, the human-centered view of ethics reached its most sophisticated development. Kant's view is still recognizably part of the tradition that goes back one hand to Aristotle, and the other to the consistent Christian doctrine that human beings partake of both the material world and the spiritual world. From Aristotle, Kant takes the view that animals 'are there merely as a means to an end. That 
como meio para nada. Aos homens, ao contrário das coisas, atribui-se uma dignidade que lhe é inerente. Porém outros exemplos podem ser considerados de valor intrínseco, como se depreende da obra de Dworkin: é o caso da obra de arte e de um animal ameaçado de extinção. Horroriza pensar na destruição de tal obra ou na extinção de uma espécie.

$\mathrm{O}$ valor instrumental de uma coisa concerne à possibilidade de auferir um resultado ou conseguir algo usando essa coisa como instrumento, veículo. É o caso clássico do dinheiro e dos remédios que, em si mesmo considerados, isolados de qualquer circunstância (custo, doença) nada valem, para nada servem.

Por fim, poderemos dizer que algo é subjetivamente valioso se possui um valor pessoal, que interessa a certa pessoa. A vida, diz o autor em tela, é intrínseca, subjetiva e instrumentalmente valiosa. ${ }^{378}$

Ocorre que há pensadores que discordam do fato de terem as coisas um valor inerente. A importância das coisas não passaria de algo atribuído. A serventia de um objeto para alguém traduziria para essa pessoa um grande valor.

Aprofundando a teoria da objeção independente, Dworkin aventa as hipóteses de se considerar algo sagrado. Assim, escreve que algo poderá revestir-se de importância intrínseca ou por associação (designação), ou pela história dessa coisa. A história natural das espécies, por exemplo, é responsável pela variedade dos seres vivos, bem como pelo nível de complexidade dos organismos que habitam o planeta.

O ser humano, a espécie Homo sapiens, estaria no ápice de toda essa cadeia evolutiva. Isso representaria, sob o prisma biológico, mais um fator a delinear a dignidade da pessoa humana. E isso mostra um grande valor, agregado ao longo de milhões de anos. Mas não é tão-somente pela natureza que se verifica a importância histórica. Dworkin exemplifica que uma obra de arte pode ser valiosa pelo modo que veio a existir ${ }^{379}$.

Contudo sob o aspecto da dignidade biológica, que conferiria um valor sagrado aos humanos, é fato que essa formulação não é imune a críticas. Para David Boonin, por exemplo, seria errôneo considerar que somos o resultado do processo de evolução humana, colocando os homens topograficamente no cume de toda cadeia viva. Trata-se de uma interpretação equivocada da teoria da evolução das espécies. Não somos um produto

end is man'. From the Christian doctrine, Kant retained the picture of human beings as split between two worlds. One was, as always, the material world, governed by physical laws. The other, however, Kant presented in a characteristic Enlightenment form, as the world of reason. It was because animals could not reason, and 'are not self-conscious' that they exist 'merely as a means to an end'. Humans, on the other hand, as reasoning, self-conscious and autonomous beings, must be respected as ends in themselves".

${ }^{378}$ DWORKIN, Ronald. Domínio da vida: aborto, eutanásia e liberdades públicas. São Paulo: Martins Fontes, 2003, pp. 96-100

${ }^{379}$ Ibid., pp. 102-8. 
supremo da natureza, mas o resultado de variações aleatórias guiado pela seleção natural. As outras espécies, nesse sentido, teriam também um grande valor, pois sobreviveram a esse processo evolutivo ${ }^{380}$.

A noção do sagrado torna-se, pois, crucial para o entendimento do sentido que a perda representa no caso do aborto.

Num primeiro momento, até intuitivamente, pode se dizer que a interrupção da gravidez é a perda de uma vida, ceifando um projeto humano em seu estágio inicial. Enfim, a noção de perda, aqui, envolve expectativas futuras, destacando-se a quantificação temporal do que poderia ser vivido.

Poder-se-ia concluir, levando em conta o critério temporal, que seria moralmente menos relevante a morte de alguém com idade mais avançada do que a de um jovem. Através do referido parâmetro, o que importa é a expectativa de vida. No entanto, esse argumento é fraco, falho. Conforme assevera Dworkin, essa

(...) concepção de perda simples é inadequada porque se concentra apenas em possibilidades futuras, naquilo que poderá ou não acontecer no futuro. Ignora a verdade crucial de que a perda de vida é comumente maior e mais trágica devido ao que já aconteceu no passado ${ }^{381}$

De fato, considerar apenas o quantum de vida em relação ao tempo pode ensejar situações paradoxais: seria pior interromper uma gravidez de duas semanas do que uma

${ }^{380}$ BOONIN, David. A defense of abortion. Cambridge: Cambridge University Press, 2005, pp. 30-31. "Dworkin sugeriu que poderíamos ver os seres humanos como a culminação de um longo processo histórico de evolução, e portanto considerados sagrados (num sentido não teísta). Mas, como no mínimo um crítico de Dworkin assinalou, essa sugestão assenta-se numa compreensão profundamente mal direcionada do que a teoria da evolução mantém. Essa teoria nos caracteriza não como o produto supremo de uma força natural ordenada, mas meramente como a tentativa resultante de pequenas variações aleatórias guiadas pela seleção natural (Rachels, 1994:272). Neste aspecto, é igualmente verdadeiro que toda espécie é o ponto culminante de uma longa evolução histórica. Portanto, não há razão para nossa história evolutiva para nos conferir um status moral que não é conferido igualmente a todas as espécies que sobreviveram a este processo. Críticos do aborto rejeitarão essa reivindicação de que todas as espécies são moralmente iguais, e, portanto, críticos do aborto não podem apelar a essas considerações" (tradução nossa). No original: "Dworkin has suggested that we might view human beings as the culmination of the long historical process of evolution, and so sacred (in the nontheistic sense) on account. But as at least one critic of Dworkin's has pointed out, this suggestion rests on a deeply misguided understanding of what evolutionary theory maintains. That theory pictures us not as the supreme product of some naturally ordered force, but merely as the tentative result of minor random variations guided by natural selection (Rachels 1994:272). In this respect, it is equally true of every species that it is the culmination of a long historical evolution. So there is no reason for our evolutionary history to confer a moral status on us that it does not confer equally on all species that have survived this process. Critics of abortion will reject the claim that all species are of equal moral status, and so critics of abortion cannot appeal to such considerations".

${ }^{381}$ DWORKIN, Ronald. Domínio da vida: aborto, eutanásia e liberdades públicas. São Paulo: Martins Fontes, 2003, p. 121. 
gravidez em estágio avançado, quando o feto já é viável, ou seja, quando poderá sobreviver no caso de um parto prematuro.

O problema do aborto não pode ser lançado em termos de "mais vida" ou "menos vida”, já que não é possível sequer lidar com as estimativas e probabilidades que envolvem a existência futura. O debate em torno do assunto, nesses termos, enfraquece-se, uma vez fundado em argumentos insatisfatórios, ou pelo menos insuficientes.

A questão modifica-se quando, ao invés da noção pura de perda, acrescenta-se a ideia de frustração. Ora, nem toda perda causa frustração, mas poderá causá-la, conforme as expectativas, os investimentos e projetos.

Ainda assim, as polêmicas surgem, pois liberais e conservadores não se entendem quanto ao que seria a pior frustração. Para os primeiros, a morte prematura minimizaria a frustração. Já para os conservadores, adiar a morte poderia ser considerado menos grave ${ }^{382}$. Urge distinguir o que perpassa essa divergência, diferenciando as noções de investimento biológico e humano.

No primeiro caso, quase sempre vem à tona a comparação da vida a um milagre, ou a uma perfeição da natureza. É um mal imenso contrariar ou desprezar esse investimento, que vem sendo feito ao longo de milhares de anos. É, pois, contra a ordem natural das coisas interferir no curso da vida humana. Essa defesa soa um tanto religiosa, e por certo acaba sendo usada por antiabortistas que, para além da consideração de uma ordem natural, vislumbram, antes de tudo, um projeto divino.

Já o ideal do investimento humano considera que a frustração na perda de uma vida deve ser contextualizada com os investimentos pessoais, os planos, as "contribuições criativas" de outras pessoas. Observa-se que além do feto há outros seres que devem ser considerados. Importa, aqui, tanto as contribuições passadas como as expectativas futuras. Nesse sentido, o aborto poderia ser justificado em alguns casos. Há uma ampliação das possibilidades do debate, uma vez que, além da vida do feto, considera-se a vida da mãe, dos familiares etc.

Isso é o que acaba por justificar uma grande variação entre posições acerca do aborto, havendo aqueles que, atribuindo grande valor ao investimento natural, condenam

\footnotetext{
382 Ibid., pp. 124-6. Referindo-se à morte de um feto com anomalia letal o autor escreve que, para algumas pessoas, "a morte imediata do feto em um caso como este, é uma frustração mais terrível do milagre da vida do que seria a vida breve e penosa de uma criança, uma vez que esta poderia ao menos concretizar uma pequena parte, ainda que insignificante, do investimento natural. Para outras pessoas, seria uma frustração ainda pior permitir que essa vida fetal continuasse, uma vez que acrescentaria, à lamentável perda da criação biológica de um ser humano deformado, a terrível perda dos investimentos emocionais e pessoais que outros houvessem feito em tal vida, e principalmente a própria criança, antes de sua inevitável morte prematura”.
} 
qualquer modalidade abortiva, nos casos mais extremos, até quando há risco de morte para a mãe. Para esses, seria melhor que a natureza ditasse o curso da vida: matar o feto (comissão) é mais grave do que deixar morrer a mãe (omissão).

Contudo, nunca é demais destacar: a sacralidade da vida humana tem em sua estrutura de pensamento, muitas vezes, algo de dúbio. De fato, há quem defenda que a vida é sagrada, sem especificar qual vida deve ser protegida. Outras situações põem em conflito duas vidas, não havendo critérios uníssonos que justifiquem a permanência de uma delas em detrimento da outra.

Não só isso: a concepção de que toda vida é sacrossanta, desde a concepção, sofre investidas contundentes nesse mundo pós-moderno, e uma visão que nela se assente está inexoravelmente fadada ao colapso. É oportuno destacar, nesse ínterim, a lição de Eduardo Carlos Bianca Bittar, que ressalta a fluidez, a desintegração de parâmetros, a fugacidade, porosidade, incerteza, indefinições que caracterizam as notas da pós-modernidade, podendo concluir, que

onde o fervor moral das sociedades tradicionais é absorvido pelos costumes amolecidos e adocicados pelas promessas de satisfação, provimento, felicidade e gozo, o império do consumo ampara diante do desamparo mundano (...) fica claro, portanto, que em casos como o aborto anencefálico, da morte induzida, pesquisa com células-tronco, entre outros tantos, não se pode pretender que uma visão de mundo predomine e se imponha sobre as ações dos outros ${ }^{383}$.

Para Hilton Japiassu, a pós-modernidade aparece como uma espécie de Renascimento dos ideais banidos pela modernidade racionalizadora. Daí a onda de comportamentos e atitudes irracionais e desencantados, o crescimento do ceticismo quanto aos valores fundamentais da modernidade ${ }^{384}$.

${ }^{383}$ BITTAR, Eduardo C. B. O Direito na pós-modernidade. Rio de Janeiro: Forense Universitária, 2009. pp. $458-476$.

384 JAPIASSU, Hilton. Desistir do pensar? Nem pensar!:criando o sentido da vida num mundo funcional e instrumental. São Paulo: Letras\&Letras, 2001, pp. 56-65. O autor menciona sete características fundamentais da pós-modernidade, em seguida especificando com tom crítico o teor do relativismo axiológico: "a questão ética ocupa um lugar bastante importante na ideologia dos pós-modernistas. Ao adotarem uma forma de relativismo moral absoluto, consideram um grave pecado do racionalismo o fato de ter anunciado a existência de um domínio ético independente dos indivíduos e definido o conjunto dos princípios aos quais deveríamos nos submeter e conformar. A expressão explícita (e detestável) dessa visão modernista reside no "transcendentalismo" kantiano acreditando que, além de um mundo físico regido por leis universais objetivas, existe um mundo moral também regido pelas mesmas leis, mas autônomo em relação ao primeiro. Ao considerar a transcendência (confundida com transcendentalismo) uma ilusão, os pós-modernistas opõem, ao transcendentalismo ético esclarecido, uma visão da moral como fator essencialmente individual. Chegam mesmo a afirmar: o próprio conceito de moral só possui sentido quando 
Além disso, a ideia de que a vida é sagrada é um argumento que tanto pode ser usado por opositores do aborto, como por pessoas que consideram lícita a sua prática, significando, assim, uma forma retórica de argumentação, que pode servir aos dois lados da discussão ${ }^{385}$. Deveras, os argumentos pró-vida condenam a interrupção da gravidez por vislumbrarem, nesse fato, a morte de um ser inocente, o feto. Já os que defendem os argumentos pró-escolha entendem que a vida humana da mulher também é sagrada, sendolhe lícito optar por interromper uma gravidez que lhe causa extremo sofrimento psicológico.

Podemos dizer que a concepção de sacralidade, como salienta Peter Singer, é aceita sem muita reflexão por quase todos, até que alguma situação nos conduza a uma reflexão mais acurada sobre os fundamentos dessas ideias, assentadas no corpo social, e nos ponha a refletir sobre tudo aquilo que era aceito sem crítica $^{386}$. Novamente, vale ressaltar a reflexividade discursiva e o caráter dialógico que envolvem a Bioética.

Ademais, muitas coisas podem ter um valor sagrado. Não é incomum vermos nas mais diversificadas culturas do globo uma grande estima e consideração a elementos não anímicos, ou mesmo o respeito à vida de determinados animais não humanos ${ }^{387}$.

fundado na vida real e concreta dos indivíduos. Não somente os juízos morais emanam do espírito dos indivíduos mas a responsabilidade só pode ser vivida no interior da consciência individual. A moral se reduz a um fato subjetivo". Tal crítica se torna expressa mais adiante, ao se referir ao "reino da demissão ética", ou mesmo num consumismo moral.

${ }^{385}$ BOONIN, David. A defense of abortion. Cambridge: Cambridge University Press, 2005, p. 27. Como escreve Boonin, "embora o termo santidade da vida humana seja frequentemente associado com o movimento popular de oposição ao aborto, é frequentemente invocado na defesa de outras posições que os críticos e defensores do aborto tipicamente compartilham de igual modo" (tradução nossa). No original: "although the term sanctity of human life is often associated with the popular movement opposed to abortion, it is often invoked in defense of the other positions that critics and defenders of abortion alike typically share".

${ }^{386}$ SINGER, Peter. Rethinking life and death: the collapse of our traditional ethics. New York: St. Martin's Griffin, 1996, p. 57. "Nós todos gostamos da noção do valor intrínseco da vida humana. Nós aceitamos uma tal nobre ideia sem muito escrutínio crítico, a menos que isto não nos impeça de fazer algo que achamos ser realmente importante. Então, um dia achamos que isto está nos impelindo a fazer coisas despropositadas, ou de igual modo conduzindo a um desastre. Então, olhamos melhor as finas frases que prontamente aceitamos. E começamos a nos perguntar por que um dia acreditamos naquilo. Então deixamos de lado" (tradução nossa). No original: "We all like the notion of the intrinsic worth of human life. We accept such a noble idea without much critical scrutiny, as long as it does not restrict us from doing what we really think is important. Then one day we find it is making us do things that are manifestly pointless, or likely to lead to disaster. So we take a better look at the fine phrases we so readily accepted. And start to wonder why we ever believed them in the first place. Then we drop them".

${ }^{387}$ Ibid., p. 165. Destaca Singer que "tem havido culturas, especialmente no oriente, que consideram que toda vida é sagrada, incluindo a vida de animais não humanos. Outras culturas têm tido uma visão muito mais restrita acerca da santidade da vida, punindo somente a morte sem motivo de um membro da tribo ou do grupo nacional, e aceitando como eticamente não problemática a morte de estrangeiros, ou crianças recémnascidas indesejadas. A tradição ocidental é incomum na ênfase à sacralidade de toda vida humana" (tradução nossa). No original: "there have been cultures, especially in the east, that have held that all life is sacred, including the lives of nonhuman animals. There have been other cultures that have had a much more restricted view of the sanctity of life, punishing only the unprovoked killing of a member of the tribe or 
No que concerne à vida humana, no entanto, existe uma vertente dominante que preconiza a intangibilidade do homem, e que pode ser ligada ao apogeu do Antropocentrismo. Isso quer significar que o ser humano, no centro de tudo, tem em consideração especial a proteção da vida.

Em inúmeros aspectos o caráter especial da vida humana se revela. O aspecto religioso, o puramente biológico ou o racional são alguns dos elementos considerados. A criação descrita no "Gênese", por exemplo, alça o humano a uma dignidade existencial diferenciada, pois o homem é considerado imagem e semelhança de seu criador ${ }^{388}$.

Durante o Renascimento, a ideia de que o homem está no centro do universo ganha uma tônica destacada, especialmente nos países ocidentais e sob a influência do Cristianismo. Marsílio Ficino, um dos principais pensadores do Renascimento, destacava esse lugar especial ocupado pelos homens ${ }^{389}$. A influência do Cristianismo na elaboração da tese de sacralidade da vida humana não pode ser negada, sendo bandeira hasteada até hoje, especialmente quando se cuida de temas como o aborto e a eutanásia.

Ensina-nos Singer que

o cristianismo trouxe ao mundo romano a idéia de singularidade da espécie humana, que herdou da tradição judaica, mas na qual insistia com grande ênfase em razão da importância que conferia à alma imortal do ser humano. Aos seres humanos, e só a eles entre todos os seres vivos na terra, estava destinada uma

national group, and accepting as ethically unproblematic the killing of outsiders, or unwanted newborn infants. The western tradition is unusual in its emphasis on the sanctity of every human life".

${ }^{388}$ Ibid., p. 166. "Os seres humanos têm sido vistos como especiais porque eles são os únicos de todas as coisas vivas feitas à imagem e semelhança de Deus. Além disso, Deus deu-lhes poder sobre todas as outras coisas viventes. Para esses dois marcos críticos de distinção entre os seres humanos e os animais não humanos, um terceiro foi adicionado, primeiro nos antigos escritos judaicos, e depois com maior ênfase no Cristianismo: a crença de que os humanos, somente eles entre todas as coisas vivas, têm almas imortais, e sobreviverão à morte" (tradução nossa). No original: "Human beings are seen as special because they alone of all living things were made in the image of God. In addition, God gave them power over all the other living things. To these two critical marks of distinction between human beings and non-human animals, a third came to be added, first in later Jewish writings, and then with much more emphasis under Christianity: the belief that humans, alone of all living things, have immortal souls, and so will survive death".

${ }^{389}$ Ibid., p. 167. Destaca Peter Singer que "durante e depois do Renascimento, filósofos desafiaram alguns aspectos da Filosofia Escolástica de São Tomás de Aquino e outros filósofos medievais, mas não o lugar especial dado aos seres humanos. Os seres humanos eram únicos porque, embora parte do mundo fídico animal, eles tinham almas imortais e portanto eram ligados aos anjos e a Deus. Marcilio Ficino, um dos mais influentes filósofos italianos do Renascimento, descreveu os humanos como o "centro da natureza, o meio do universo, a corrente do mundo" (tradução nossa). No original: "during and after the Renassaince, philosophers challenged some aspects of the scholastic philosophy of Aquinas and other medieval thinkers, but not the special place given to human beings. Human beings were unique because, although part of the physical world of animals, they had immortal souls and so were linked to the angels and God. Marsilio Ficino, one of the most influential of the Italian philosophers of the Renassaince, described humans as "the centre of nature, the middle of the universe, the chain of the world". 
vida após a morte do corpo. Essa noção introduziu a idéia distintamente cristã da sacralidade de toda a vida humana ${ }^{390}$.

A adjetivação da palavra "vida", nesse contexto, adquire um sentido de relevância, pois é restritivo: tem o escopo de circunscrever o âmbito do discurso aos homens. Assim, podemos concluir que a ideia de sacralidade da vida tem como paradigma a vida humana. "As pessoas costumam dizer que a vida é sagrada, o que, quase sempre, não passa de força de expressão (...) Quando as pessoas afirmam que a vida é sagrada, estão pensando na vida humana" 391 .

Esse tratamento de superioridade da vida dos animais humanos é denominado por alguns autores de especismo, o que seria tão condenável quanto as outras formas de preconceito, como a que se assenta no tratamento desigualitário e discriminatório baseado no gênero ou em conceitos de raça.

Assim, a ideia de sacralidade da vida humana sofreria a objeção de uma crença baseada em um preconceito, uma hierarquização injustificável que determina a utilização de animais como meros instrumentos, à mercê da vontade dos homens. Nas palavras de Singer, "a crença de que a vida humana, e tão-somente ela, é sacrossanta, é uma forma de especismo" 392 .

Peter Singer aprofunda em suas obras o respeito à vida animal, o que é possível, como já pudemos verificar neste estudo, graças ao princípio da igual consideração dos interesses.

Essa ponderação, que diz respeito à distinção estabelecida entre a vida dos seres da espécie humana e todos os outros, é um dos reflexos do dogma da sacralidade da vida que, bem especificado, traz uma limitação: não é a vida de qualquer organismo senciente que importa. Isto já revela, do ponto de vista científico, uma certa incoerência dos discursos sobre a vida, ou ao menos deixa subentendida a restrição da espécie.

As polêmicas que envolvem as condutas humanas e a vida dos animais merecem tratamento aprofundado, o que requereria um estudo próprio, incompatível com o objeto

\footnotetext{
${ }^{390}$ SINGER, Peter. Libertação animal. Porto Alegre: Lugano, 2004, pp.216-217.

${ }^{391}$ SINGER, Peter. Ética prática. São Paulo: Martins Fontes, 2002, p. 93-94.

${ }^{392}$ SINGER, Peter. Libertação animal. Porto Alegre: Lugano, 2004, p. 20; SINGER, Peter. Ética prática. São Paulo: Martins Fontes, 2002, p. 160. Nesta obra, destaca Singer que "o fato de um ser pertencer ou não à nossa espécie não é mais relevante para o erro de matá-lo do que o fato de ele ser, ou não, um membro de nossa raça”.
} 
que foi aqui delimitado. No entanto, não poderia deixar de ser feita a referência ao especismo $^{393}$.

Há, ainda, algumas outras inconsistências. Para Alison M, Jaggar, outra consequência de se atribuir à vida humana valor sagrado com base tão apenas no código genético poderia conduzir a conclusões absurdas. Assim, nesse passo, seria preciso conferir o mesmo valor e importância às células gaméticas, pois são, indiscutivelmente, células com código genético humano ${ }^{394}$.

A ideia de sacralidade da vida, apesar de séculos de incontrastabilidade, sofre outros golpes, e como visto, na projeção de Singer, não se sustentará por muito tempo, numa verdadeira ruína do Antropocentrismo.

A história da ciência permite verificar alguns acontecimentos importantes para uma nova consideração do homem, e consequentemente, da vida humana. Com Copérnico, houve uma substituição do antigo sistema astronômico grego, e a Terra deixou de ser o centro do universo, contrastando uma tradição dominante, custando-lhe a própria vida na fogueira. Darwin, com sua teoria, revolucionou o entendimento reinante à época, chocando inúmeros cientistas, especialmente com seu escrito A Origem das espécies, pois o homem já não é visto de maneira absolutamente incontrastável, num pedestal biológico inatingível e isolado; é um animal. Com Lineu e a sua classificação de plantas e animais, o homem foi inserido no mesmo gênero dos chimpanzés ${ }^{395}$.

393 A obra citada, Libertação Animal, é ponto de referência e fonte de consulta obrigatória para os argumentos concernentes à Ética e os animais. Para o autor, alguns animais não humanos poderiam ser considerados pessoas, o que enseja muita polêmica.

${ }^{394}$ TOOLEY, Michael; WOLF-DEVINE, Celia; DEVINE, Philip E.; JAGGAR, Alison M. Abortion: three perspectives. New York: Oxford University Press, 2009, p.157.

395 SINGER, Peter. Rethinking life and death: the collapse of our traditional ethics. New York: St. Martin's Griffin, 1996, pp. 169-170. Explica Singer que as ideias de Copérnico foram depois absorvidas pelo Cristianismo, que anteriormente as condenava: "mais tarde, quando a igreja não poderia mais suprimir a ideia de Copérnico, procedeu a absorvê-la. Humanos não eram mais o centro do universo, mas eles eram ainda a imagem de Deus" (tradução nossa). No original: "Later, when the church could no longer suppress the Copernican idea, it managed instead to absorb it. Humans were not at the centre of the universe any more, but they were still made in the image of God". Escrito semelhante apresenta H. Tristam Engelhardt Jr. Na lição do pensador, "enquanto as raízes religiosas do consenso ético e metafísico estavam se fragmentando, o progresso nas ciências minava as interpretações estabelecidas quanto ao lugar do homem no mundo e até no cosmos. Esse progresso também fortaleceu as expectativas do racionalismo secular. Em 1492, Colombo descobria a América, no sentido radical de revelar a geografia de nosso mundo e a vasta amplitude das culturas do globo. Quando a primeira cópia da obra de Nicolau Copérnico, De revolutionibus orbium celestium, foi colocada em seu leito de morte na Prússia oriental, no dia 24 de maio de 1543, fez-se um legado no sentido de uma mudança nas idéias, que deveriam transformar-se em metáfora para dramáticas e profundas mudanças na visão do mundo. A revolução de Copérnico foi uma das muitas modificações em idéias e interpretações que deixariam nossa visão secular desprovida de um sentido de perspectiva final ou absoluta: o homem deixava de ser o centro do universo". Cf. ENGELHARDT JR., H. Tristam. Fundamentos da Bioética. São Paulo: Loyola, 2004, pp. 28-29. 
A doutrina da sacralidade da vida, cujos reflexos inegavelmente se espraiam pelo Direito, vê surgir algumas rachaduras em sua construção, e os buracos e inconsistências tomam corpo dia a dia, com redefinições de conceitos tidos como incontrastáveis, flexibilizações necessárias para solução de controvérsias éticas e abandono de concepções tidas como verdadeiras.

Assim é que se põe, ao lado de uma doutrina da sacralidade da vida, a defesa de dignidade da vida. Ora, tem-se, nesse segundo caso, o referencial à qualidade da vida. Como escreve Francesco D’Agostino,

a ética da santidade da vida reconhece a presença em cada ser vivo de uma intrínseca e específica razão de ser, que deve ser respeitada em seu princípio. A ética da dignidade da vida considera, ao contrário, que é tarefa do próprio ser vivo fornecer uma razão à própria existência. Não é possível recompor em unidade essas doutrinas ${ }^{396}$.

Essas duas visões, santidade da vida (Sanctity of Life, SOL) e qualidade da vida (Quality of Life, QOL) também mereceram análise crítica de Stephen Smith, que expõe as premissas de cada uma delas contrapostas para, ao final da sua exposição, propor uma nova forma de avaliar o valor da vida. Observa que a doutrina da santidade da vida tem como alguns dos adeptos reconhecidos John Finnis e John Keown. D’outro lado, entre os que se posicionam pelo valor da qualidade da vida, podem ser citados Peter Singer, John Harris e David Price. A forma como Stephen Smith refuta o oposicionismo entre essas duas visões é realizada utilizando como ponto de partida a vida do personagem George Bailey, do filme A Felicidade não se Compra (It's a Wonderful Life, 1946), dirigido por Frank Capra, concluindo que não se trata de visões necessariamente antagônicas e excludentes ${ }^{397}$.

A respeito da obra de John Finnis, por exemplo, encontramos no livro Natural Law and Natural Rights a ideia de que um valor primordial básico é a vida (the value of life), significando este termo todo o aspecto da vitalidade, o que se relaciona, diz o autor, à higidez física (saúde corporal), e ações/atividades que buscam realizar esse escopo ${ }^{398}$.

\footnotetext{
396 D’AgOSTINO, Francesco. Bioética segundo o enfoque da Filosofia do Direito. São Leopoldo: Unisinos, 2006, p.188.

${ }^{397}$ Cuida-se do capítulo 5 da obra The right to life and the value of life: orientations in law, politics and ethics. Great Britain: Ashgate, 2010, pp.101-116, intitulado de "How we Value Life: George Bailey and the Life Not Worthy of Being Lived".

${ }^{398}$ FINNIS, John. Natural law and natural rights. New York: Oxford, 1996, p.86.
} 
Porém, Francesco D’Agostino refuta com veemência ambos os extremos, defendendo

a necessidade de repensar radicalmente as duas categorias tradicionais que, mais do que outras, são utilizadas pela maioria dos estudiosos de bioética: a santidade da vida (apreciada pelos bioeticistas de formação metafísica e, em especial, pela bioética católica) e a disponibilidade da vida (defendida, ao contrário, pelos bioeticistas de formação 'laica' e, em especial, pelos utilitaristas). Segundo a primeira perspectiva, a norma fundamental da bioética poderia ser adequadamente expressa pelo imperativo defende a vida!, um imperativo de caráter deontológico absoluto e, portanto, não suscetível de qualquer tipo de exceção. Resulta que, segundo essa primeira perspectiva, a vida humana deveria ser considerada tout court indisponível. Segundo a outra perspectiva, a norma fundamental da bioética deveria ser reconhecida no imperativo defende a qualidade de vida! Como consequiência, a vida nunca deveria ser defendida por si só, mas apenas no limite em que se mostrasse merecedora de ser vivida: avaliação essa desprovida de referências absolutas e, portanto confiada ao próprio indivíduo e às suas capacidades autônomas de escolha ${ }^{399}$.

Assim, para o autor, nem a doutrina da santidade da vida nem a da qualidade da vida mostram-se adequadas, propondo, pois, um novo modo de enquadramento da questão, em que não podem simplesmente ser opostas em termos de um dogma irracional de uma razão antidogmática. E, salienta D’Agostino que

por ser reciprocamente irredutíveis, as éticas da santidade da vida e da qualidade de vida têm um fundamento em comum: ambas pressupõem como objeto a vida, sem problematizá-la, sem discuti-la; a antinomia que as divide não diz respeito à definição de vida humana como tal, mas às modalidades (teoréticas e existenciais) de enfoque de vida, ou seja, o sentido que lhe é conferido $^{400}$.

Apesar da crítica de D’Agostino às duas correntes, entendemos que a segunda mostra-se mais razoável, já que não reduz a decisão a um caráter absoluto. Porém, apesar

${ }^{399}$ D’AGOSTINO, Francesco. Bioética segundo o enfoque da Filosofia do Direito. São Leopoldo: Unisinos, 2006, p.187.

${ }^{400}$ Ibid., p. 189. 
de aceitarmos como mais adequada, não significa que seja absolutamente perfeita: deve sujeitar-se a algumas ponderações.

Em primeiro lugar, a ética da qualidade da vida deve considerar sempre as decisões dos sujeitos morais envolvidos, sob pena de tornar-se arbitrária. De fato, para exemplificar, se alguém deseja manter-se vivo, por sua vontade, apesar de dores atrozes ou sofrimento intenso, não é dado a ninguém fazer a escolha pelo outro, como imposição, sob o argumento de alívio ou de melhora.

Em segundo lugar, e como consequência da primeira ponderação, a ideia de qualidade de vida, extremamente louvável, não pode ser levada ao extremo, sob o risco de tornar-se incoerente e de mesmo matiz que a doutrina criticada, a da sacralidade da vida.

Por certo, a crítica de que a doutrina da intangibilidade da vida é dogmática, devendo ser afastada, e que, por outro lado, deve-se buscar a qualidade de vida, a todo custo, torna-se também dogmática; uma "verdade" absoluta e incontrastável, única a ser atingida. Qualquer concepção que se pressuponha como única correta não se sustenta a uma análise mais consistente.

Propõe D'agostino, assim, um novo foco, que não diz respeito nem à sacralidade, nem à qualidade da vida. Como escreve,

as novas técnicas biomédicas, antes mesmo de pôr em jogo o sentido da vida humana, tendem a alterar sua própria identidade. Esse é, portanto, o verdadeiro problema, o problema absolutamente novo, frente ao qual nos põe a biomedicina: o problema da nossa identidade ${ }^{401}$.

Mas não podemos deixar de destacar alguns outros argumentos que contrariam a versão dogmática da sacralidade.

Na opinião de Peter Singer, é chegada a hora de uma nova revolução quanto a este aspecto, dada a insuficiência e incoerência dessa ética que toma a vida humana ao seu centro $^{402}$. Porém, ainda persiste a defesa da vida humana na quase totalidade dos debates

${ }^{401}$ Ibid., pp. 189 e 193. Segundo D’Agostino, “é apenas a partir da defesa da identidade que se torna possível operar pela defesa da dignidade da vida".

${ }^{402}$ SINGER, Peter. Rethinking life and death: the collapse of our traditional ethics. New York: St. Martin's Griffin, 1996, pp. 188-189. Escreve o autor: “(...) é difícil ver um longo e benéfico futuro para uma ética tão paradoxal, incoerente em pretensão como nossa convencional ética da vida e da morte se tornou. Novas técnicas médicas, decisões em casos legais marcantes e mudanças na opinião pública estão ameaçando a desabar o edifício todo. Tudo o que tenho feito é reunir e apresentar a fraqueza fatal que se tornou aparente nas últimas duas ou três décadas. Para qualquer um que pense claramente sobre toda gama de questões que eu levantei, a moderna prática médica se tornou incompatível com a crença no igual valor de toda vida humana. / É hora de outra revolução copernicana. Será, uma vez mais, uma revolução contra um conjunto de 
bioéticos, o que enseja uma reflexão acerca das consequências de conferir-lhe uma envergadura do porte atribuído.

Mas há outras formas de se esquivar da ideia de santidade inerente à vida, de quem quer que seja. É o caso da noção de unidade narrativa, desenvolvida por Alasdair MacIntyre. Esta "ocorre quando os elementos em uma vida se encaixam para formar um todo significativo, uma série de eventos com um propósito inteligível, uma direção e uma estrutura global" ${ }^{403}$. Discorre o autor dizendo que, no caso de um feto ou de um bebê,

não existe uma narrativa centrada em curso, a história é imperfeita e, portanto, uma conclusão particular não seria exigida pelos elementos já em vigor. A morte desse indivíduo não estragaria uma boa história, pela simples razão de que sua história ainda seria muito incipiente ${ }^{404}$.

Esse argumento importaria, sem dúvida, numa espécie de gradação do valor da vida e do significado da morte, o que poderia ser variável para cada indivíduo. Cuida-se, portanto, de uma individualização do valor da vida, por certo bastante polêmica, e que remete, entendemos, à ideia já estudada acerca dos investimentos humanos e biológicos para se aferir a moralidade de tirar a vida de um ser.

No mais, a considerar a intangibilidade da vida de um membro da espécie Homo sapiens, a discussão perde sentido, pois não há razoabilidade possível, e toda decisão que signifique o sacrifício da vida será sempre censurável. Cristaliza-se, pois, uma forma de

ideias que herdamos de um período no qual o mundo intelectual era dominado por uma perspectiva religiosa. Porque irá mudar nossa tendência em ver os seres humanos como o centro do universo ético, encontrará resistência feroz daqueles que não querem aceitar tal sopro em nosso orgulho humano. Primeiramente, haverá os problemas próprios dessa mudança, que precisará pisar cuidadosamente sobre o novo solo, pelas muitas ideias que parecerão tão chocantes. Mas afinal as mudanças virão. A visão tradicional de que toda vida humana é sacrossanta não é capaz de lidar com a variedade que problemas que enfrentamos. A nova visão oferecerá uma aproximação mais fresca e promissora" (tradução nossa). No original: "(...) it is hard to see a long and beneficial future for an ethic as paradoxical, incoherent and dependent on pretence as our conventional ethic of life and death has become. New medical techniques, decisions in land mark legal cases and shifts of public opinion are constantly threatening to bring the whole edifice crashing down. All I have done is to draw together and put on display the fatal weakness that have become apparent over the last two or three decades. For anyone who thinks clearly about the whole range of questions I have raised, modern medical practice has become incompatible with belief in the equal value of all human life". E conclui o autor: "It is time for another Copernican revolution. It will be, once again, a revolution against a set of ideas we have inherited from the period in which the intellectual world was dominated by a religious outlook. Because it will change our tendency to see human beings as the centre of the ethical universe, it will meet with fierce resistance from those who do not want to accept such a blow to our human pride. At first, it will have its own problems, and will need to tread carefully over new ground. For many the ideas will be too shocking to take seriously. Yet eventually the change will come. The traditional view that all human life is sacrosanct is simply not able to cope with the array of issues that we face. The new view will offer a fresh and more promising approach".

${ }^{403}$ MACMAHAN, Jeff. A Ética no ato de matar, Porto Alegre: Artmed, 2011, p. 186.

${ }^{404}$ Ibid., p. 187. 
absolutismo ético, sendo a vida o parâmetro universal e primordial a ser considerado. Surgem os argumentos lógicos, que tentam racionalizar e, de certo modo, demonstrar essa forma de verdade acerca da inviolabilidade humana.

Importa verificar como são construídos esses argumentos lógicos, que utilizam formas de silogismos para certificar que a conduta abortiva, ao violar a vida humana, é moralmente e racionalmente errada.

\subsection{Silogismos: a argumentação lógica em defesa da vida}

Podemos notar entre as teses que defendem a vida do feto desde a concepção, com a postura de condenar as práticas abortivas, a utilização de argumentos lógicos, construídos sob a forma silogística, concatenando premissas para delas obter uma só conclusão: é errado tirar a vida do feto.

Como define Alaôr Caffé Alves,

\footnotetext{
o silogismo, como expressão verbal, é uma forma de argumentação dedutiva, pela qual de um antecedente [duas premissas], relacionando dois termos [extremos] a um terceiro [o médio], tiramos um conseqüente [conclusão] que une esses dois termos entre $\mathrm{si}^{405}$.
}

Cuida-se de argumento que, sob o aspecto formal, reforçaria a proibição de matar um feto, o que significa um apelo à razão. Ora, não se trataria de um problema puramente valorativo, mas sim de uma construção capaz de evidenciar, logicamente, uma espécie de verdade.

Uma das elaborações teóricas que conduzem à conclusão referida parte de três premissas basilares.

A primeira premissa (P1) considera que o feto é vida humana desde a concepção. Utiliza-se, ainda que de modo indireto, a ideia de início da vida tomando como marco esse momento (concepção). A segunda premissa (P2) tem em consideração que toda vida é sagrada - e, nesse ponto, remetemos o leitor ao tópico anterior, em que a noção de sacralidade da vida foi aprofundada. A terceira premissa (P3), que ainda se assenta na ideia de que a vida é sagrada, faz surgir dessa noção o direito à vida. Ou seja, pelo fato de uma

405 ALVES, Alaôr Caffé. Lógica: pensamento formal e argumentação. São Paulo: Quartier Latin, 2005, p.264. 
vida ser sagrada, o indivíduo tem direito à vida. Por fim, como conclusão, tira-se que o feto tem o direito à vida desde a concepção ${ }^{406}$.

Esse argumento lógico tem suas premissas atacadas por diversos autores.

A premissa P1 pode ser atacada tendo em vista a ambiguidade do termo concepção, que ora está a indicar a ideia de fecundação, ora a noção de nidação, que constituem dois fatos absolutamente distintos, com consequências diferentes em termos práticos. No primeiro, independentemente da implantação no útero, a vida já tem um status de importância. Contudo, no segundo sentido, é necessária, além da fertilização, a implantação do embrião fecundado.

Entra em cena, pois, a função ativa do intérprete que deverá determinar um dos sentidos possíveis. Como salientamos no início desse capítulo, as formas silogísticas não conduzem a uma conclusão que deva ser considerada necessariamente correta. Não há que se falar em absolutismos hermenêuticos. Na seara da ciência biológica, não poderia ser diferente. Os dados da natureza, ao serem apreendidos pelo intelecto, passam por uma elaboração linguística, e mesmo que se estabeleçam relações meramente causais, haverá, invariavelmente, interpretação.

Mais discussões surgem no que concerne às premissas P2 e P3.

No caso da premissa $\mathrm{P} 2$, temos de considerar que a ideia de sagrado não é unívoca, ultrapassando a noção meramente religiosa de sacralidade da vida, considerando fatores não teológicos para determinação da ideia do sagrado ${ }^{407}$.

A premissa P3, por seu turno, torna-se objeto de crítica, especialmente se considerarmos uma noção não teológica do sagrado. Pergunta Boonin: por que, do fato de considerar-se o zigoto incrível ou fantástico, seguiria que somente poderia ser destruído em

\footnotetext{
${ }^{406}$ BOONIN, David. A defense of abortion. Cambridge: Cambridge University Press, 2005, p. 28.

${ }^{407}$ Ibid., p. 30. O autor cita, neste ponto, Bernard N. Nathanson, médico do documentário $O$ grito silencioso, analisado neste capítulo, e cuja noção de sacralidade da vida não teria fundamento religioso: "Uma das figuras mais citadas nos trabalhos conhecidos que se opõem ao aborto é Bernard N. Nathanson, um médico e oponente do aborto que já foi diretor da maior clínica de aborto do mundo e cofundador da Associação Nacional para Revogação das Leis sobre o Aborto (agora a Liga de Ação Nacional pelos Direitor do Aborto) e que se identifica como um 'ateu convicto', cuja posição sobre o aborto 'nunca foi influenciada minimamente pelos impérios da fé"” (tradução nossa). No original: "One of the most commonly cited figures in popular works opposed to abortion is Bernard N. Nathanson, a physician and opponent of abortion who was once a director of the largest abortion clinic in the world and a cofounder of the National Association for Repeal of Abortion Laws (now the National Abortion Rights Action League) and who identifies himself as a "convinced atheist" whose position on abortion has "never been influence in the slightest by the empires of faith"”. Dworkin, como vimos pouco acima, detalha as diferentes noções de sagrado, não meramente religiosas.
} 
razões extremas? O fato de o embrião ser tratado com reverência não é a mesma coisa que estatuir que matá-lo não é moralmente permitido ${ }^{408}$.

Ainda considerando os argumentos silogísticos, vale destacar que Peter Singer retoma algumas formulações que contêm tão-somente duas premissas.

$\mathrm{O}$ primeiro silogismo é arquitetado com base na ideia de que o feto é um ser humano inocente. Nesses termos, tem-se: P1: é errado matar um ser humano inocente. P2: um feto humano é um ser humano inocente. Daí se conclui que é errado matar um feto humano. Outro silogismo, apelando à ideia de potencialidade, baseia-se nas seguintes premissas: P1: é errado matar um ser humano em potencial. P2: um feto humano é um ser humano em potencial. Disso decorre que seria errado matar um feto humano ${ }^{409}$.

Muitos outros argumentos lógicos podem ser construídos para tornar o aborto uma prática injustificável. Do ponto de vista da lógica formal, podem constituir premissas verdadeiras ${ }^{410}$. No entanto, uma análise sobre a razoabilidade material que está subjacente ao raciocínio faz com que as conclusões não se sustentem. Materialmente, esses argumentos são questionáveis, podendo, inclusive, constituir sofismas. Na lição de Alaôr Caffé Alves,

o sofisma pode ser uma argumentação materialmente falsa sob a forma logicamente correta [legítima] ou uma argumentação materialmente verdadeira sob a forma logicamente incorreta [ilegítima], ou, ainda, uma argumentação formal e materialmente incorreta, sempre, em todos os casos, com aparência de certa ${ }^{411}$.

\footnotetext{
${ }^{408}$ Ibid., pp. 31-32. "Por que decorreria do fato de o zigoto ser incrível, surpreendente ou fantástico o fato de que nós somente poderíamos matá-lo sob circunstâncias extremas que também justificariam matar você e eu? (...) Dizer que alguém deveria tratar o feto com reverência não é o mesmo que dizer que matá-lo não é permitido moralmente" (tradução nossa). No original: "Why should it follow from the fact that the zygote is amazing, astonishing, or awesome, that we are only permitted to kill it under the sort of extreme circumstances that would also justify killing you and me? (...)To say that one should treat the fetus with reverence is not the same as saying that killing it is morally impermissible".

409 SINGER, Peter. Ética prática. São Paulo: Martins Fontes, 2002, pp.159-162. Ver também: KUHSE, Helga; SINGER, Peter. Individuals, humans, and persons: the issue of moral status. In: SINGER, Peter. Unsanctifying human life.Oxford: Blackwell, 2002, p. 192.

${ }^{410}$ SINGER, Peter. Rethinking life and death: the collapse of our traditional ethics. New York: St. Martin's Griffin, 1996, p. 100. “Como critério de lógica formal, o argumento é valido. Se nós aceitamos as premissas, devemos aceitar a conclusão. Já que o aborto de fato retira a vida do feto, teríamos que concordar que o aborto é errado. De outro modo, se queremos rejeitar a conclusão, devemos rejeitar pelo menos uma das premissas" (tradução nossa). No original: "As a matter of formal logic, the argument is valid. If we accept the premises, we must accept the conclusion. Since abortion does take the life of the fetus, we would then have to agree that abortion is wrong. Conversely, if we want to reject the conclusion, we must reject at least one of the premises".

${ }^{411}$ ALVES, Alaôr Caffé. Lógica: pensamento formal e argumentação. São Paulo: Quartier Latin, 2005, p. 292.
} 
Alguns autores, ao analisarem a questão da lógica jurídica, fazem observação crítica pertinente, haja vista o encantamento que geralmente traz a roupagem do raciocínio lógico-formal, quase que uma ponte de ouro para a "verdade". Chaïm Perelman, por exemplo, aduz que a lógica jurídica

não é uma lógica da demonstração formal, mas uma lógica da argumentação, que utiliza não provas analíticas, que são coercivas, mas provas dialéticas - no sentido aristotélico dessa distinção - que visam a convencer, ou pelo menos, persuadir o auditório (o juiz nessa ocorrência), de modo que o leve a dirimir com sue decisão uma controvérsia jurpidica ${ }^{412}$.

E, no campo do Direito, destaca Kelsen que

a interpretação de uma lei não deve necessariamente conduzir a uma única solução como sendo a única correta, mas possivelmente a várias soluções que na medida em que apenas sejam aferidas pela lei a aplicar - têm igual valor, se bem que apenas uma delas se torne Direito positivo no ato do órgão aplicador do Direito - no ato do tribunal, especialmente. Dizer que uma sentença judicial é fundada na lei, não significa, na verdade, senão que ela se contém dentro da moldura ou quadro que a lei representa - não significa que ela é a norma individual, mas que é uma das normas individuais que podem ser produzidas dentro da moldura da norma geral ${ }^{413}$.

Daí conclui-se que qualquer forma de silogismo deve ser vista com cautela, sem a consideração de um sentido único e verdadeiro passível de ser apreendido das premissas em que se estrutura.

Ainda com Perelman, e relacionando à complexidade das decisões judiciais, podese dizer que

cada vez que o recurso à lógica basta para conhecer a resposta de uma questão, esta poderia ser fornecida por uma máquina programada para tanto, e o recurso ao juiz poderia ser evitado. Mas cada vez que uma decisão de justiça deve ser capaz de apreciar a importância dos valores em jogo, que deve poder pesar o pró e o contra, para chegar a uma decisão bem motivada, que leve em conta, de uma forma equilibrada, as exigências da equidade e da segurança jurídica, o juiz não

${ }^{412}$ PERELMAN, Chaïm. Ética e Direito. São Paulo: Martins Fontes, 2005, p. 500.

${ }^{413}$ KELSEN, Hans. Teoria Pura do Direito. São Paulo: Martins Fontes, 2009, p. 391. 
poderá limitar-se ao cálculo de um autômato, mas deverá recorrer a todos os recursos da argumentação, tanto em sua deliberação íntima, quanto na redação de uma sentença que comprometerá sua responsabilidade pessoal ${ }^{414}$.

Pelo exposto, conclui-se que se está diante da insuficiência da lógica estritamente formal para conclusões a respeito da pessoalidade do feto, e da dignidade em si da vida biológica.

Entendemos ser interessante finalizar esse capítulo com a análise do documentário $O$ grito silencioso, que também problematiza a questão do aborto em alguns aspectos. Com isso, manteremos a análise fundada no aspecto imagético que se propõe nesta dissertação.

\subsection{Análise do documentário $O$ grito silencioso}

O grito silencioso talvez constitua um dos documentários mais utilizados quando se pretende ilustrar o "mal" das práticas abortivas, especialmente em relação à ofensa com relação à vida do feto em desenvolvimento. A questão central desta película diz respeito à consideração do especial status do feto humano como uma pessoa que deve ter o direito à vida respeitado, desde antes de nascer. $\mathrm{O}$ entrave moral ao aborto, que constitui o cerne do documentário, toma contorno na equiparação, ao menos substancialmente, do feto aos adultos humanos.

Destaca Thomas A. Shannon que a significância moral do feto continua a ensejar discussões éticas difíceis para a maioria da população, mormente quanto à sua valoração $^{415}$.

Nos poucos minutos de documentário, podemos verificar os argumentos pró-vida lançados por um médico, Dr. Bernard Nathanson, que, antes de militar contra o aborto, foi diretor de uma clínica que realizava procedimentos abortivos. Nesse caso, é nítida a argumentação de autoridade que se alavanca na película, pois se trata da voz de alguém com conhecimentos científicos, um médico obstetra e ginecologista, que de certo modo

${ }^{414}$ PERELMAN, Chaïm. Ética e Direito. São Paulo: Martins Fontes, 2005, p. 516.

${ }^{415}$ SHANNON, Thomas A. The moral significance of brain integration in the fetus. In HUMBER, James M.; ALMEDER, Robert. F. Bioethics and the Fetus. Totowa: The Humana Press, 1991, p.123. Como escreve o autor "por um lado, como uma entidade vivente com um genoma humano, alguém deve afirmar o valor do embrião; por outro, devemos levar em consideração outros valores externos ao feto. Assim, as difíceis questões éticas são como valorar o feto e que status o feto tem em comparação com outros valores" (tradução nossa). No original: "on the one hand, as a living entity with the human genome, one must affirm value to the embryo; on the other hand, we need to take into account other values external to the fetus. Thus, the difficult ethical questions are how to value the fetus and what status has that value in comparison to other values". 
reviu sua posição anterior, deixando de praticar o aborto em mulheres que o procuravam, o que reforçaria as teses aduzidas.

Salientamos que o fato de se tratar de um documentário não induz à neutralidade. A versão dos fatos que será mostrada nos cortes e imagens passa sempre por uma seleção, de maneira que é impossível separar do documentarista ou do diretor a subjetividade, que se mescla, por exemplo, no destaque dado a um acontecimento. Assim, mesmo que haja uma tentativa de demonstração de uma "verdade absoluta", ela nunca será alcançada: será sempre parcial.

De início, após a advertência da autenticidade de todo material que será apresentado, a ultrassonografia de um feto nos é mostrada para introduzir a problemática do aborto, em fala da qual podemos extrair o nome dado ao documentário: agora podemos perceber o grito silencioso na face dessa criança que agora enfrenta iminente extinção.

Há um apelo emocional, em que figura como protagonista um tema extremamente polêmico. Aliado a isto, o poder da imagem é capaz de transmitir e fazer ver, afetando o interlocutor que assiste. Não há como, num primeiro olhar, deixar de pensar naquilo que os olhos captam ${ }^{416}$.

O médico, Dr. Nathanson, inicia o relato dizendo que os avanços da ciência possibilitam agora um novo olhar em relação ao feto, o que antes só poderia ser objeto de fé: considerá-lo humano não ultrapassava a crença de cada um. Porém, com o surgimento da Fetologia, em 1970, aliada às novas tecnologias (ultrassonografia, monitor eletrônico do coração fetal, entre outros procedimentos), essa história mudou.

A imagem ultrassônica, ensina o médico, possibilita que vejamos o feto em movimento: sem dúvida, essa criança a nascer é também outro ser humano, outro membro da humanidade, sem distinção de maneira alguma a qualquer um de nós.

${ }^{416}$ TOOLEY, Michael; WOLF-DEVINE, Célia; DEVINE, Philip E.; JAGGAR, Alison M. Abortion: three perspectives. New York: Oxford, 2009, p. 105. Como escrevem Célia Wolf-Devine e Philip E. Devine, "uma mulher que vê imagens de ultrassom de alta resolução do feto é menos propensa a optar por um aborto. Tais imagens ajudam-na a ultrapassar o pensamento abstrato sobre a sua gravidez, e perceber a realidade concreta que está na verdade presente em seu útero, e que lhe deveriam ser apresentadas. A réplica de que mostrar as imagens de ultrassom poderia contrariá-la (depois de tudo que foi deliberado para abortar, não deveríamos tornar as coisas mais difíceis para ela) não chateará. Se ela é considerada responsável o suficiente para fazer esta decisão, ela é responsável o suficiente para encarar a verdade. Sonegar informação ou obscurecer a verdade para fazê-la sentir-se melhor é, em termos kantianos, tratá-la como um mero meio ao invés de um fim em si mesmo" (tradução nossa). No original: "a woman who sees high resolution ultrasound pictures of the unborn is far less likely to choose abortion. Such pictures help her get beyond thinking abstractly about her pregnancy, and realize the concrete reality of what is actually present in her womb, and therefore she should be shown them. The rejoinder that showing her pictures or ultrasound images might upset her (after all she has decided to get an abortion, so we should not make it harder on her) just will not do. If she is regarded as responsible enough to make this sort of decision, she is responsible enough to face the truth. To withhold information, or shade the truth to make her feel better, is, in kantian terms, to treat her as mere means rather than an end in herself". 
Notamos uma verdadeira metalinguagem, pois a imagem é utilizada para falar da imagem, ou seja, o documentário, como forma de linguagem visual, explora a imagem presente na tecnologia da ultrassonografia.

O médico utiliza, então, uma forma de raciocínio, em que o feto toma espaço como vítima do aborto, sofrendo o mal causado pela prática que lhe tira a vida. Assim, fala na criança torturada, desmembrada, desarticulada, destruída, esmagada pelos insensíveis instrumentos de aço do aborteiro - e deixa claro o apelo emocional que pretende incutir em suas falas. Trata-se da perspectiva atávica, que considera reações espontâneas, baseadas em sentimentos humanos ancestrais, como destacado por Célia Wolf-Devine e Philip E. Devine ${ }^{417}$

Essa forma de transmissão dos argumentos baseia-se numa exploração ampla das emoções primárias do telespectador em relação às imagens mostradas, de maneira que a dor e o sofrimento que são mostrados têm o objetivo de fazer com que nos sintamos consternados, emocionados.

Em projeção aos horrores que vemos, ficamos também horrorizados. Nessa perspectiva,

imitamos as emoções exibidas aos nossos olhos e isto torna a apreensão da ação do filme mais nítida e afetiva. Simpatizamos com quem sofre e isto significa que a dor que vemos se torna a nossa própria dor. Compartilhamos da alegria do amante realizado e da tristeza de quem chora o seu luto; sentimos a indignação da esposa traída e o medo do homem em perigo. A percepção visual das várias manifestações dessas emoções se funde em nossa mente com a consciência da

\footnotetext{
${ }^{417}$ Ibid., p. 69. Como salientam, no original, Celia Wolf-Devine e Philip E. Devine, nesse interessante livro com contrapontos entre diversos modos de analisar o problema do aborto, "outra consideração é o sentimento espontâneo que os seres humanos têm em relação aos membros de nossa própria espécie. Bebês representam o futuro, e despertam sentimentos protetivos de mulheres e homens. Às vezes estes apelos são ressentidos, entretanto, e o uso de imagens de fetos abortados inteiros no movimento pró-vida frequentemente provoca uma reação emocional violenta. Tais sentimentos provocam uma resposta àqueles caracteres da natureza humana que compartilhamos com nossos ancestrais pré-humanos; por esta razão os denominamos de 'atávico'. Aborto necessariamente engaja tais sentimentos, e uma 'discussão racional da questão que não os leve em consideração não é realmente falar sobre o aborto" (tradução nossa). No original: "another consideration is the spontaneous feeling that human beings experience toward immature members of our own species. Babies represent the future, and elicit protective feelings from both women and men. Sometimes these appeals are resented, however, and the use of pictures of whole and aborted fetuses in pro-life agitation often provokes a violently emotional reaction. Such feelings are response to those features of human nature we share with our prehuman ancestors; for this reason we call them 'atavistic'. 'Abortion necessarily engages such feelings, and a 'rational' discussion of the issue that does not take them into account is not really talking about abortion".
} 
emoção manifestada; é como se estivéssemos vendo e observando diretamente a própria emoção $^{418}$.

Dr. Nathanson mostra-nos, também, as fases do desenvolvimento fetal, do estado pré-natal até as 28 semanas, anotando que não há uma diferença substancial ou de forma do ser em desenvolvimento, que pode ser considerado, desde os estágios iniciais, uma pessoa, um ser humano: esta pequena pessoa de doze semanas é uma criatura, inegavelmente um ser humano. Já tem ondas cerebrais desde seis semanas, seu coração está funcionando há oito semanas e todo o resto das funções humanas é exatamente como as nossas.

Esse argumento, muito utilizado nas campanhas antiaborto, reflete a ideia de continuиm vital, ou seja, desde a fecundação já existe um ser humano que desenvolverá, em questão de tempo, não havendo diferenças ontológicas substanciais entre o feto e o bebê que nascerá, entre o bebê e a criança, ou entre a criança e o homem adulto. Tudo se resolve numa continuidade existencial, apenas sujeita ao desenvolvimento e às alterações biológicas pelas quais também passa o homem após o nascimento, sem que com isso deixe de ser considerado uma pessoa.

Haveria, portanto, arbitrariedade na escolha de um momento para atribuição da personalidade jurídica? O feto pode ser considerado pessoa, já que contém o projeto do homem por nascer?

O médico cita o livro de Obstetrícia (William Obstetrics), utilizado em faculdade de Medicina dos Estados Unidos, em que o feto é alçado à condição de verdadeiro paciente, ou como escrito no prefácio dessa obra: felizmente, entramos numa era em que o feto pode ser já considerado e tratado como o nosso segundo cliente. Quem poderia sonhar, mesmo há alguns anos, que poderíamos atender um feto como médico.

De fato. A Medicina atual possibilita uma gama tão variada de procedimentos que podem ser realizados com o feto ainda dentro do útero materno que já podemos tratá-lo como um verdadeiro paciente ${ }^{419}$.

\footnotetext{
${ }^{418}$ MUSTENBERG, Hugo. As emoções. In: XAVIER, Ismail (org). A experiência cinematográfica. Rio de Janeiro: Edições Gerais Graal, Embrafilmes, 1983, p. 51.

${ }^{419}$ BONNICKSEN, Andrea L. The embryo as patient. In HUMBER, James M.; ALMEDER, Robert. F. Bioethics and the Fetus. Totowa: The Humana Press, 1991, p.145-170. A autora cita inúmeras técnicas aplicadas aos embriões, como biópsia embrionária, microcirurgia e terapia gênica, destacando as implicações éticas que toda técnica pode trazer nas relações humanas. Podemos fazer uma analogia com os procedimentos à disposição da medicina fetal, que pode ensejar inúmeros dilemas ético-jurídicos, ainda sequer cogitados pelo Direito.
} 
Na cena que segue, o médico pretende ilustrar, sob o ponto de vista da vítima, como se realiza o aborto. A demonstração de como o feto é morto, no documentário, envolve a utilização de alguns instrumentos, como espéculo, tenáculo, sonda, dilatadores, aparelho de sucção, pinça de pólipo.

O médico refere-se especificamente aos aborteiros como as pessoas que interrompem a gravidez, citando passo a passo o iter procedimental que resultará na expulsão do feto e destruição da criança: pedaços do corpo são separados um por um, até ficarem somente fragmentos do corpo e a cabeça. A cabeça é grande demais para passar pela tubulação, utilizando o aborteiro a pinça de pólipo para retirada da cabeça da criança: a cabeça é então dilacerada e seus pedaços removidos com seus respectivos ossos.

O aborto registrado, conta Dr. Nathanson, foi realizado por um médico que trabalhava em duas diferentes clínicas de aborto, e que já havia realizado, mesmo jovem, mais de 10.000 abortos. No entanto, após assistir ao procedimento que foi gravado, o médico nunca mais realizou abortos, pois ficou chocado. Além disso, a mulher que operacionalizava a câmera, uma feminista pró-aborto, após as imagens do abortamento, nunca mais quis discutir sobre o assunto.

É possível notar, na argumentação do médico, a experiência de pessoas que, favoráveis ao aborto, ao assistirem às imagens de um procedimento abortivo, mudaram de opinião, o que sugere ao telespectador defensor da realização de práticas abortivas uma modificação de postura.

A ideia de movimento da criança dentro do ventre materno é destacada pelo médico, referindo-se, ainda, ao ambiente uterino como santuário. Pode-se dizer que, ínsito à expressão utilizada, encontra-se o argumento de sacralidade da vida humana.

Por muito tempo aliou-se a existência da vida à ideia de movimento, e o vídeo dá a impressão de um movimento consciente do feto, que tentaria de todos os modos lutar pela própria vida. Como fala Dr. Nathanson, podemos notar que a ponta de sucção, que está aqui, quando se move em direção à criança, ela recua do objeto, e começa a produzir movimentos violentos e agitados. A criança se move com mais determinação. Sua posição muda constantemente (...) a ponta de sucção ainda não tocou na criança e mesmo assim ela permanece agitada e movendo violentamente. A criança virou agora outra vez de perfil (...) mas esta ponta de sucção que vemos se movendo violentamente na parte inferior da tela é um instrumento mortal que eventualmente irá destruir a criança. E fala, enfim, na boca da criança aberta, prestes a enfrentar sua própria extinção, como se ela estivesse emitindo um grito silencioso. 
A atitude de aduzir, a todo momento, aos movimentos fetais reflete a personalização do feto, como ente com vida própria, que sabe dos perigos que a sonda do aborteiro representa. Os traços de pessoalidade ${ }^{420}$ são praticamente enumerados, como a citação à posição do polegar, à fuga da ponta de sucção, ao grito silencioso. A ideia de pessoalidade do feto, bem como o valor absoluto da vida humana desde a concepção, podem ser considerados conceitos-imagem que se constroem ao longo do documentário.

No entanto, poderíamos atribuir às características que o médico destaca um caráter de reflexo, comum a todos os seres biológicos, com alguma estrutura neural razoavelmente desenvolvida, e que significa a fuga de estímulos dolorosos que provenham do ambiente. Além disso, alguns caracteres de personalidade advêm, na verdade, de outrem, não sendo intrínseco ao ser que é personalizado. É o que pode ocorrer inclusive com objetos ou animais, aos quais atribuímos importância afetiva a ponto de personalizá-los.

Durante o aborto, explica o médico, as batidas do coração do feto aumentam e a movimentação torna-se maior, como que percebendo a agressão ao seu santuário. Diz: está se afastando, e podemos vê-la mover para a esquerda do útero, numa tentativa patética de tentar escapar aos terríveis instrumentos que o aborteiro usa para extinguir a sua vida (...) não há dúvida alguma que a criança percebe o perigo mortal que a espera.

Os argumentos atávicos continuam presentes, sendo que ao dizer que a cabeça é separada do corpo, já desmembrado, a reação só pode ser de repulsa, mormente se for considerado o estado pessoal do feto ${ }^{421}$.

O médico refere-se aos termos específicos que poderão estar presentes durante um aborto. Fala que o aborteiro e o anestesista têm um código secreto entre eles, que os protege da pavorosa realidade dos fatos. $O$ aborteiro e o anestesista se referem à cabeça da criança, que agora é chamada de número " 1 ". O anestesista então perguntará ao aborteiro: o número "1" já saiu? Já acabamos?

Novas características continuam a ser atribuídas ao feto quando o médico se refere ao fim do procedimento abortivo: indefeso e frágil ser humano. Traz-se à colação mais um dos argumentos antiaborto, qual seja o de considerar o feto um ser humano inocente, incapaz de defender-se contra as agressões externas.

\footnotetext{
${ }^{420}$ Ao definirmos pessoa, no capítulo quinto, especificaremos os atributos que costumam ser associados ao ente dotado de personalidade.

${ }^{421}$ TOOLEY, Michael; WOLF-DEVINE, Célia; DEVINE, Philip E.; JAGGAR, Alison M. Abortion: three perspectives. New York: Oxford, 2009 p. 87. Para Celia Wolf-Devine e Philip E. Devine, o feto tem o status de uma pessoa, sendo sujeito, no mínimo, do direito à vida.
} 
Finalizado o procedimento abortivo, Dr. Nathanson começa a discorrer sobre algumas estatísticas relacionadas ao aborto, referindo-se à decisão Roe vs Wade, que pode ser considerada um marco, nos Estados Unidos, no que diz respeito à legalização da interrupção da gravidez.

Esse famoso precedente acabou por estabelecer, em 1973, no Estado do Texas, uma divisão cronológica de três fases para análise da possibilidade de abortar. No primeiro trimestre, a decisão de abortar deveria ficar a cargo da mãe. No segundo trimestre, o Estado passa a dispor de um poder de tutela, podendo interferir na decisão acerca da interrupção da gravidez. Por fim, no terceiro trimestre, ressalvados os casos de risco de morte, não há mais possibilidade de, livremente, abortar. A decisão teve por base a $14^{\mathrm{a}}$ Emenda da Constituição, que protege o direito à privacidade, não havendo um direito absoluto do Estado em proibir o aborto, na visão do juiz Blackmun (que ao lado dos juízes Stewart e Rehnquist analisou o caso) $)^{422}$.

Os parâmetros trazidos pela decisão Roe vs Wade, segundo narra Nathanson, fizeram com que o número de abortos saltasse de 100.000 para 750.000, comparando-se os dados. Ademais, o médico fala que o número na época do documentário já ultrapassava 1.500.000 casos por ano.

Mais um argumento antiabortista é trazido ao debate, relacionando as consequências da legalização do aborto na sociedade à ampliação do número de abortos praticados. Porém os dados específicos de uma sociedade não servem como argumento totalizante e universal. As leis não produzem as mesmas consequências em todas as sociedades, havendo hipóteses em que conteúdos similares apresentariam impactos completamente diversos, ora ensejando repulsa e desobediência, ora confirmando a autoridade normativa.

Outra ponderação pode ser realizada sobre esse argumento, um tanto falacioso: seria a legalização a causa do aumento do número de abortos praticados ou, com a legitimação das condutas, haveria tão-somente uma retirada do véu de clandestinidade que cobria condutas recorrentes no seio social? Não há uma correlação lógica entre legalização e aumento desenfreado do abortamento.

Peter Singer cita alguns argumentos liberais, entre os quais o que diz respeito às consequências de leis restritivas. No caso, como salienta o autor, não se trata de discutir o 422 Analisamos detidamente este caso por ocasião da Iniciação Científica por nós desenvolvida, à qual já
fizemos referência. 
problema moral do aborto, mas de centrar o estudo nos efeitos de uma legislação que proíbe algo. Entre os argumentos liberais, há a ideia de que

em geral, as mulheres que pretendem abortar estão desesperadas e procurarão um abortador de fundo de quintal ou usarão remédios populares. $\mathrm{O}$ aborto feito por um médico qualificado é uma operação tão segura quanto qualquer outra, mas as tentativas de procurar fazer aborto com profissionais desqualificados geralmente resulta em graves complicações médicas e, às vezes, até mesmo na morte. Portanto, o resultado da proibição do aborto não é tanto a redução do número de abortos realizados, mas, sim, o aumento das dificuldades e dos perigos para mulheres com uma gravidez indesejada ${ }^{423}$

Porém, na opinião daqueles que contestam a possibilidade de abortar, a lei deve trazer uma mensagem efetiva de proteção aos fracos e indefesos, que não podem se defender. A proibição do aborto é necessária e tem o efeito de obstar a tirania dos fortes sobre os fracos, realçando o valor da vida. Além disso, o obstáculo legal à pratica do aborto serviria como um desestímulo às praticas médicas, facilitadas com a permissão legal, e mesmo para as mulheres, que resistiriam à pressão de abortar ${ }^{424}$.

Em continuidade aos argumentos sobre os impactos do aborto na sociedade, especialmente considerada a legalização, Dr. Nathanson começa a falar da indústria do aborto, especificando os custos de cada aborto e o quanto de dinheiro seria movimentado, com a divisão dos valores entre médicos e empresários que dirigem as clínicas, que se proliferaram como redes de restaurantes. Diz ainda, na toada de sua pretensão de veracidade dos argumentos expendidos, que esse dinheiro, dinheiro do aborto é manchado

${ }^{423}$ SINGER, Peter. Ética prática. São Paulo: Martins Fontes, 2002, p.153.

${ }^{424}$ TOOLEY, Michael; WOLF-DEVINE, Célia; DEVINE, Philip E.; JAGGAR, Alison M. Abortion: three perspectives. New York: Oxford, 2009 p. 101. Como escreve Célia Wolf-Devine e Philipe E. Devine, “o aborto deveria ser regulado porque a função da lei é proteger os mais fracos contra a tirania dos mais fortes e as pessoas não nascidas, necessitadas e indefesas, requerem a proteção contra a destruição. A lei deve também veicular a mensagem de que a vida dos que ainda não nasceram é merecedora de respeito, e que o aborto é uma prática ruim. $\mathrm{O}$ aborto ilegal torna mais fácil para um médico relutante resistir à pressão de praticar um aborto. E a retórica dos direitos constitucionais tem sido uma arma poderosa nas mãos daqueles que tentam superar escrúpulos conscientes contra o aborto, tanto em si como em outros" (tradução nossa). No original: "abortion should be regulated because the function of the law is to protect the weak against the tyranny of the strong and the helpless unborn person requires protection from destruction. The law must also convey de message that unborn life is deserving of respect, and that abortion is a bad practice. That abortion is illegal makes it easier for an unwilling physician to resist pressure to perform one, or for an unwilling woman to resist pressure to have one. And the rhetoric of constitutional rights has been a powerful weapon in the hands of those attempting to overcome conscientious scruples against abortion, both in themselves and in others". 
pelo sangue, não só das inocentes vítimas do aborto, como também pelas mãos sujas do crime sindicalizado nos Estados Unidos.

Notamos que há uma tentativa de reforço na argumentação do médico quando se refere à outra vítima do aborto: a mãe. Nessa ordem de argumentação, ele fala que quando discutimos o aborto temos que entender que a criança por nascer não é a única vítima. As mulheres são vítimas também, tanto como as crianças o são. Não foi dito às mulheres a verdadeira natureza da criança por nascer, não lhes foi mostrado os fatos reais sobre o que o aborto realmente é. $\mathrm{E}$, em seguida, especifica os males e consequências fisiológicas que a prática abortiva pode causar: as mulheres, em grande número, centenas, milhares, dezenas de milhares têm tido seus úteros perfurados, infectados ou sofreram destruição total de seus órgãos reprodutores como resultado de uma operação da qual não possuem o conhecimento verdadeiro.

A prática abortiva, na opinião do médico, seria fruto de um consentimento mal informado, ou de uma falta de conhecimento sobre as consequências que o aborto pode $\operatorname{acarretar}^{425}$. Assim, acaba por criticar o obscurantismo causado por uma real conspiração concertada por organizações e pessoas interessadas em ocultar as informações essenciais sobre o aborto, sobre sua verdade.

Porém urge destacar que o problema da informação, conforme entendemos, não está compartimentado às práticas abortivas. É algo muito mais amplo, e abrange a educação sexual, acesso a programas de saúde, conhecimento dos direitos, entre tantas outras questões. O problema é antecedente, não consequente.

E, seria correto dizer que todas as consequências nefastas apontadas não são propriamente decorrência de uma falta de conhecimento sobre as consequências da prática abortiva, mas sim da precariedade em que são realizadas muitas vezes, escondidas na clandestinidade das clínicas de fundo de quintal, sem equipamentos ou profissionais capacitados que consigam conter as intercorrências de um acaso.

Finalizando o documentário, Dr. Nathanson retoma o argumento de autoridade: sua compreensão sobre o problema advém de experiências pessoais, modificadas com os novos conhecimentos sobre o desenvolvimento fetal.

Conclui que todo feto é um ser humano, igual a qualquer um de nós, e parte integral da comunidade humana. Agora, a destruição de uma vida humana não é solução para o que basicamente é um problema social. E acredito que, recorrer a essa violência é

${ }^{425}$ Ibid., p. 105. Na opinião de Célia Wolf-Devine e Philipe E. Devine, para a tomada de decisão, é necessário fornecer toda informação que possa ser relevante para a escolha que será realizada. 
admitir que a ciência e, pior ainda, a ética, estão empobrecendo. Convida, então, todas as pessoas a encontrarem uma melhor solução, tendo como prioridade o respeito à vida humana, em contraposição àquilo que considera um genocídio.

Convém dizer que a participação do feto numa "comunidade humana" faz parte da ideia do comunitarismo, que reforça a proteção ao ser ainda não nascido. Indaga-se se os humanos são seres dotados de uma individualidade apartada de tudo e de todos que os cercam ou se, ao contrário, nascem numa rede de relações dentro da qual são socializados.

Nesse sentido, o individualismo opõe-se ao comunitarismo, destacando alguns autores que, para que nos tornemos autônomos, antes de tudo, dependemos de outras pessoas, o que enseja uma ética do cuidado ${ }^{426}$.

Por todo o exposto, pode-se concluir que a ideia de uma absoluteza da vida, considerada sagrada desde a concepção, só conduz a uma possibilidade: proibição do aborto. Assim, não restam escolhas possíveis se se graduar o homem biológico como ápice de um processo biológico considerando-o, a partir daí, intangível.

A levar em conta o relativismo axiológico, visto no capítulo precedente, temos que muitos não concebem a vida dessa forma, o que tornaria injusta a imposição de semelhante visão. Por certo, casos há em que o "valor da vida" cede no caso concreto, e o sujeito da relação prefira sacrificar uma vida em desenvolvimento - o que pode acontecer até mesmo em rejeição à autoridade posta, às leis proibitivas existentes em relação ao aborto.

Ora, pertencer à espécie humana (Homo sapiens) não tem o condão de criar regras absolutas e incontrastáveis. Seria desconsiderar a variedade humana, o grande número de necessidades presentes nas mais diversas sociedades e especialmente as peculiaridades dos dramas humanos que cercam as pessoas. Como visto em Vera Drake, há razões várias que motivam o abortamento, circunstâncias emocionais que abalroam a vida e conduzem à difícil decisão de interromper a gravidez.

A vida, apesar de bem fundamental, se tomada em sentido absoluto, aniquila os sujeitos morais, tornando despiciendas quaisquer decisões que tentem outra solução para o conflito ético porventura instalado.

\footnotetext{
${ }^{426}$ Ibid., pp. 73-75. Segundo Célia Wolf-Devine e Philip E. Devine, “os seres humanos gastam boa parte de suas vidas dependentes dos outros, e, sem a nutrição e educação fornecida por outros seres humanos, ninguém sobreviveria à infância, aprenderia uma linguagem e se desenvolveria até o ponto de se tornar autônomo" (tradução nossa). No original: "human beings spend much of their lives dependent on others, and without the nurture and education provided by other human beings no one would survive infancy, learn language, or develop to a point where they can become autonomous".
} 
Ademais, essa blindagem do homem biológico já não se sustenta com base na tão propagada visão de sacralidade, seja esse termo tomado em sentido religioso, seja considerado em sentido não teológico.

O colapso da tradicional ideia de centralidade biológica, que considera o humano como fator de proteção universal de consideração nas discussões ético-jurídicas, conduz à reflexão de que um novo parâmetro deve ser tomado em consideração nos debates. Um parâmetro que não conduza a uma impossibilidade de escolhas e que, ao contrário, leve em conta a multiplicidade de visões existentes num mundo pós-moderno, e que considere não apenas pretensos silogismos para daí se concluir uma verdade inabalável.

Enfim, vale repetir, é inegável que os filmes auxiliam na compreensão de um determinado problema humano, especialmente se conjugado com outras formas de expressão do pensamento, como o Direito. Esse saber interdisciplinar que se constrói, e que fundamenta este estudo, parte da comunicação visual propiciada pela imagem, alicerça-se na Filosofia do Direito e toma subsídios de outras áreas do conhecimento. Desse modo, podemos apresentar a problemática do aborto, sua atualidade e variedade de formas de abordagem. No entanto, não é consentânea com a investigação proposta a análise de cada abordagem possível.

Partimos da premissa de que o aborto é um fato social, que há uma cultura do aborto. Mas como enfrentar a questão do ponto de vista ético, moral e jurídico?

Assim, restringindo-nos ao problema ético-jurídico do aborto, realizamos um corte metodológico e uma delimitação do objeto de estudo. Examinar se o conceito de pessoa pode ser tomado como critério para análise das decisões sobre a interrupção da gravidez significa restringir a pesquisa à delimitação do que seja a pessoa do ponto de vista da Filosofia do Direito e verificar se o conceito é aplicável ao feto.

Não se trata, portanto, de uma análise legalista do conceito de pessoa, com fulcro no início da personalidade civil, estabelecido pelo Código Civil (artigo $2^{\circ}$ ). Aliás, esse diploma legal não define o que vem a ser a pessoa, restringindo-se a estabelecer as consequências da atribuição da personalidade jurídica, como a capacidade de direitos e deveres na ordem civil $\left(\operatorname{artigo} 1^{\circ}\right)$.

Consideramos, assim, que a pessoa adquire, no cenário atual, certo destaque na Bioética. Mas qual o seu delineamento?

É necessária, assim, uma aproximação das discussões acerca do conceito de pessoa, que tem tomado corpo nos discursos bioéticos e que tanto interessa ao Direito, que a considera como sujeito de direitos e obrigações. Mas seria, de fato, um termo capaz de 
afastar a pretensão universalista subjacente à proteção absoluta da vida? O que se entende por pessoa? Não seria um conceito arbitrário, formulado em termos linguísticos?

Adquire relevância, nesse cenário, a ideia de pessoa potencial, qualificadora do feto, o que para alguns autores justificaria a proibição do abortamento.

Com a ideia de potencialidade, atrelada está a de continuum vital, ou seja, de sequência lógica de desenvolvimento biológico do feto em adulto ${ }^{427}$, que inegavelmente seria uma pessoa a ser protegida pelo Direito. Mas a noção de potencialidade não é tão trivial como parece, e releva dedicar algumas linhas ao estudo da ideia de pessoa potencial, que frequenta as obras de Bioética e do Direito, como se fosse um fato natural verificável tanto que alguns autores dividem-na em potencialidade ativa e potencialidade passiva. Ademais, insta observar que alguns filósofos sempre estiveram às voltas com as noções de ato e potência. Afinal, qual a relevância para o Direito de algo que é em potência? Como o Direito encara, como objeto de proteção, algo que ainda não é, mas que pode ser?

Impende analisar, nesse passo, como a partir da conceituação da pessoa em termos filosófico-jurídicos se põe o debate em torno da interrupção da gravidez. Esse enfoque tem por consequência a verificação da ideia de homem pós-ontológico, ou seja, a consideração da pessoa não em termos estritamente biológicos, o que é denominado por alguns autores como "desbiologização do conceito de pessoa".

Passemos às discussões.

${ }^{427}$ Ibid., p.82. Como escrevem os autores, "ter um potencial humano não é ser um 'humano potencial': aquele que ainda não nasceu irá, no curso normal das coisas, ser apto a fazer coisas que os seres humanos normalmente fazem, como falar uma língua, raciocinar e se engajar em reflexões morais" (tradução nossa). No original: "to have human potential is not to be a 'potential human': the unborn will in the normal course of things be able to do things human beings characteristically do, such as speaking a language, reasoning and engaging in moral reflection" 


\section{CAPÍTULO 5. O HOMEM PÓS-ONTOLÓGICO: A PESSOA}

O conceito de 'pessoa' está no centro do debate bioético e de seus impactos no domínio do Direito ${ }^{428}$.

(La distinction juridique entre les personnes et les choses à l'épreuve des procréations artificielles, Roberto Andorno)

Às vezes os debatedores dizem que ser certo ou errado terminar uma gravidez depende se o embrião ou feto é uma vida humana. Mas esta não é mais a questão crítica. É claro que é vivo. A divisão celular segue desde a fertilização. E é claro que é humano, pois qualquer biólogo poderia rapidamente identificar até mesmo a blástula como da espécie Homo sapiens - não como sendo a de um macaco ou de um coelho. Não: a questão não é se é uma vida ou mesmo se é uma vida humana. A questão é se nós podemos assinalar um status pessoal à vida fetal -o status que geralmente queremos dizer quando as pessoas falam de um 'verdadeiro ser humano, 429 .

(Humanhood: essays in biomedical ethics, Joseph Fletcher)

A Bioética, conforme vimos, é um saber interdisciplinar. Mais do que isso: é uma área de conhecimento que se encontra em construção, sendo relativamente recente o despertar de um estudo próprio, bem como as tentativas de sistematização, nas obras, de temas que tradicionalmente são encarados como bioéticos.

Os postulados teóricos e normativos que essa área ostenta não logram consenso em torno dos debates éticos que se tem ao centro - nem se defende, ao menos neste trabalho, a possibilidade de a Bioética atingir verdades hermenêuticas para as controvérsias fáticas, importando destacar, isto sim, o seu estatuto dialógico.

Há uma confluência de saberes, uma contribuição mútua de cada ciência e ramo do conhecimento tendo um objeto comum; a interdisciplinaridade reclama formas de análise

\footnotetext{
428 Tradução nossa. No original: "Le concept de "personne" est au coeur du débat bioétique et de sés incidences dans lê domaine du droit".

${ }^{429}$ Tradução nossa. No original: "Sometimes discussants say that whether it is right or not to terminate a pregnancy depends on whether an embryo or fetus is a human life. But that is not the critical question any more. Of course it is alive. Cell division goes forward from fertilization. And of course it is human, since any biologist could quickly identify even a blastula as of the species Homo sapiens - not as a monkey's or a rabbit's. Not: the question is not whether it is a life or even whether it is a human life. The question is whether we may assign personal status to fetal life - the status that is usually meant when people speak of 'a truly human being”.
} 
que podem ser diversas daqueles métodos clássicos "puros" de estudo de um dado ou de um ser.

Assim se dá, também, com as relações entre a Filosofia do Direito e o universo das artes, entre os quais se destaca o aspecto imagético do cinema. No entanto, a dificuldade de lidar, metodologicamente, com a interdisciplinaridade não implica a impossibilidade - e isto nos anima, pois tomar um objeto de modo interdisciplinar significa uma abertura ao diálogo, que é sempre mais construtivo para compreensão de um fenômeno do que a simples compartimentalização.

Porém, ao lado de paradigmas que se constituíram como base do olhar bioético, a ponto de emergirem preceitos considerados fundamentos principiológicos da Bioética, como a justiça, a beneficência, a não maleficência e a autonomia ${ }^{430}$, emergem novos enfoques de análise dos problemas ético-jurídicos, de maneira que se fala em "Bioéticas", de modo plural, como reflexo da diversidade e multiplicidade moral existente, constituindo inúmeros modos de compreensão dos problemas humanos - e essa infinidade de vozes põe-se, por vezes, cada qual como a única correta, o que enseja a dogmatização.

Alguns desses enfoques têm como núcleo intangível a vida humana; outros destacam as relações que existem entre os homens, e há ainda aqueles que apontam para a questão da identidade humana.

Os estudos que sobrelevam a vida humana podem tomá-la de modo acrítico e impositivo, um dogma de fé. Cuida-se de tomar o biológico como ponto de partida e de chegada e, como pudemos observar no capítulo anterior, essa visão sofre severas críticas, correndo o risco de entrar em colapso nas próximas décadas, dado o avanço das ciências médicas e as pressões de várias ordens.

Escritos que prezam como problema da Bioética não a vida ou o sentido que esta deve assumir, mas sim a identidade humana, podem ser apreendidos principalmente na obra de Francesco D’Agostino. Qual seria, pois, a vantagem dessa abordagem, em termos bioéticos? Por que a identidade se torna nuclear para análise dos problemas que envolvem a Ética, a Biologia e o Direito? A pessoalidade apresenta, nessa linha de ideias, uma série de aprofundamentos; citando Jeff MacMahan, as abordagens se pautam pela a) presença de

\footnotetext{
${ }^{430}$ Não há uma absoluta uniformidade acerca da nomenclatura, ou número dos princípios bioéticos. Cada autor elabora o rol de princípios que variam inclusive quanto à visão que tem acerca da Bioética. Tanto é verdade que H. Tristam Engelhardt Jr. "rebatizou", entre uma edição e outra de sua obra, o princípio da autonomia, passando a denominá-lo de "princpio do consentimento". Verificar, nesse sentido: HENGELHADT JR., H. Tristam. Fundamentos da Bioética. São Paulo: Loyola, 2004, p. 17.
} 
uma alma; b) identidade partindo de um parâmetro biológico simplesmente (organismo humano); c) abordagem psicológica; e d) teoria que advoga a mente incorporada. ${ }^{431}$

Outros autores, como Kelsen, tomam o conceito de pessoa em termos estritamente normativos, o que reflete sua postura metodológica e coerência científica em sua obra. É necessário analisar mais de perto essa construção do conceito de pessoa como um conceito possível que se difere das tradicionais definições que ocupam os livros de Teoria Geral do Direito $^{432}$.

Atualmente, mais e mais se tem destacado como núcleo das preocupações bioéticas a pessoa humana. Propriamente, o relevo merecido é atribuído à pessoa, vez que entre pessoa e humano, uma verdadeira barreira se ergue. E é essa barreira que deve ser melhor compreendida - em que pese a defesa de uma equiparação entre os termos e uma verdadeira substancialização do conceito da pessoa, como proposto por alguns filósofos medievais.

Se a individualidade genética não é suficiente para compreensão do problema do aborto, já que não propicia o debate e só conduz a uma única solução possível, estudiosos e filósofos apontam o ser como parâmetro da Bioética, e não somente a vida. Haveria uma distinção entre direito à vida e direito à existência.

Daí o enfoque do homem pós-ontológico, entendendo-se a expressão como sinônimo de pessoa. Antes de compreender as consequências desse novo enfoque, é preciso especificar o que é a pessoa, qual o seu 'conteúdo' - caso haja um conteúdo. Tratase de definir os atributos do conceito.

Vale salientar antes que, a despeito dessa centralidade do conceito de pessoa nas discussões bioéticas, já que somente pessoas são sujeitos morais capazes de avaliação e de conduta ética, erige-se uma crítica concernente ao fato de essa perspectiva estar imbuída de certo preconceito em favor das pessoas.

Tal é o teor das constatações e indagações realizadas por H. Tristam Engelhardt Jr, ao se referir à abordagem que toma a pessoa como núcleo essencial. Segundo o autor,

embora esta abordagem simplifique a questão, libertando as discussões de dilemas metafísicos, possui seus próprios problemas e complicações. Primeiro, poderíamos levantar a objeção de que este modo de pensar na moralidade cria uma interpretação do universo moral indevidamente centralizada na pessoa ou

\footnotetext{
${ }^{431}$ Para aprofundamentos, consultar: MACMAHAN, Jeff. A ética no ato de matar. Porto Alegre: Artmed, 2011, pp.20-107.

${ }^{432}$ KELSEN, Hans. Teoria Pura do Direito. São Paulo: Martins Fontes, 2009, pp. 188-194.
} 
orientada para ela. E os animais, as árvores e o meio ambiente? Por acaso o universo não é mais importante que as pessoas? No entanto, são apenas as pessoas que refletem sobre o mundo e montam explicações do seu significado. Além disso, quando elas se encontram como estranhos morais, encontram-se sem a graça ou introspecção moral especial. Encontram-se com a possibilidade de agir impositivamente nas associações que criam. Essa colaboração moral coloca as pessoas como fundamento de sua textura moral secular. Somente elas podem dar permissão e transmitir autoridade ${ }^{433}$.

Ademais, H. Tristam Engelhardt Jr. esclarece que o termo pessoa é plurissignificativo, admitindo mais de um sentido, como se ocorresse uma fragmentação do humano em categorias de sujeitos. Para embasar o critério distintivo, erige a consciência ou a capacidade mental, que se reflete na habilidade de interação com o meio e com outros sujeitos.

Ora, vale ressaltar, nesse sentido, que a linguagem é uma convenção cultural, à qual o indivíduo adere desde que nasce, sem considerar as teorias comunicacionais que defendem a possibilidade de um enculturamento antes mesmo do nascimento ${ }^{434}$.

Como reflexo disso, sendo um produto social, a linguagem se apresenta muitas vezes vazada por ambiguidades, múltiplos sentidos, vaguidade de alguns termos e, além de tudo, pode ser utilizada como um verdadeiro instrumento retórico e de dominação. A esta plurissignificação conecta-se a necessidade de se interpretar. Na lição de Tércio, na situação comunicativa há uma seletividade que se realiza no discurso encetado entre os sujeitos, e “interpretar, portanto, é selecionar possibilidades comunicativas da complexidade discursiva" ${ }^{435}$.

Fala Engelhardt em um sentido estrito de pessoa, que pode ser denominado propriamente de agente moral, e em sentidos sociais de pessoa. Dentre estes, o primeiro sentido social de pessoa seria a designação dada a alguns indivíduos aos quais quase todos os direitos de uma pessoa em sentido estrito (agente moral) são atribuídos. É o caso de crianças pequenas.

Outro sentido social seria a denominação daqueles que não são mais pessoas, mas já o foram, e mantêm certa capacidade de interação, ainda que muito pequena. Pode-se

${ }^{433}$ ENGELHARDT Jr., H. Tristam. Fundamentos da Bioética. São Paulo: Loyola, 2004, p. 176.

${ }^{434}$ Verificar, neste ponto: RAFFLER-ENGEL, Walburga Von. The perception of the unborn across the cultures of the world. Seattle: Hogrefe\& Huber Publishers, p. 141 e seguintes. Ver, também: ROTHMAN, Barbara Katz. Recreating motherhood. Nova Iorque: Rutgers, 2000, p. 65.

${ }^{435}$ FERRAZ Jr., Tércio Sampaio. Introdução ao estudo do Direito: técnica, decisão, dominação. São Paulo: Atlas, 1994, p. 260. 
conceber, ainda num sentido meramente social, aqueles com sério retardo mental, que nunca foram pessoas em sentido estrito e nunca serão. Por fim, fala o autor num sentido social de pessoa para se referir àqueles que se encontram em situações de inconsciência relacionada a estados comatosos severos e permanentes ${ }^{436}$.

Não há como negar, nesse passo, que os direitos relativos às pessoas denominadas apenas em sentido social são elaborados e estabelecidos segundo o alvitre das pessoas consideradas em sentido estrito. Haveria, nesse caso, a possibilidade de leis excludentes, que poderiam deixar completamente à margem de qualquer proteção aqueles indivíduos que não se subsumem ao conceito estrito - o que revela, na verdade, uma necessidade de ponderações sob o crivo da responsabilidade.

Pensar de outro modo, sem a cautela que inspira todas as decisões que envolvam indivíduos que não são considerados sujeitos morais, pode ensejar a arquitetura de sociedades totalitárias, em que não interessam seres incapazes de consciência do mundo e de si. É questão polêmica, de fato.

Passaremos, agora, à análise de algumas das concepções sobre o conceito de pessoa na Filosofia do Direito, e especificamente, trataremos das considerações de Joseph Fletcher, e a influência do conceito na obra de Peter Singer; de John Locke; de Hans Kelsen; de São Tomas de Aquino e de Michael Tooley. Ademais, no que interessa, abordaremos as noções de núcleo significativo, entre as quais se insere a "pessoa", tratadas por Tércio Sampaio Ferraz Jr. Após essas perspectivas, interessa aprofundar a ideia de pessoa biológica, potencial, frequentemente invocada pelos opositores do aborto, que consideram a pessoa inserida num continuum vital, e a noção de pessoa moral, mesmo com a convicção de que há o uso de um sentido equivalente em outros estudiosos. Nesse sentido, pertinente a observação de Battista Mondin, segundo o qual

várias são as definições propostas, de vários gêneros e podem ser reunidas em três grupos: definições psicológicas, que são aquelas apontadas por Descartes, Hume, Fichte e, que identificam a pessoa com a auto consciência; definições dialógicas: são aquelas de Mounier, Ricoeur, Levinas, Buber, que afirmam consistir a pessoa na capacidade de dialogar com os outros; definições ontológicas, que afirmam ser a pessoa a própria essência, a substância, ou mesmo, o ser do homem ${ }^{437}$.

\footnotetext{
${ }^{436}$ ENGELHARDT Jr., H. Tristam. Fundamentos da Bioética. São Paulo: Loyola, 2004, p. 190

${ }^{437}$ MONDIN, Battista. Definição filosófica de pessoa. Bauru: Edusc, 1998, p. 25.
} 
Não trataremos especificamente desses autores, mas a divisão é válida e aplicável aos demais pensadores selecionados.

\subsection{O conceito de pessoa: a perspectiva de Joseph Fletcher}

A definição do conceito de pessoa é a tentativa de esboçar as características de um sujeito moral. Cuida-se de uma definição eminentemente filosófica, passível de críticas e reformulações conforme o entendimento do que seja um sujeito assim qualificado. Por isso, para alguns, o feto pode ser considerado pessoa, enquanto para outros, de modo algum se verificam os atributos definidores da pessoa.

Nessa empreitada, entramos no campo de uma metaética, conforme definido no capítulo terceiro.

Na lição de Alaôr Caffé Alves, pode-se dizer que

o conceito ou idéia é a forma intelectual que exprime o objeto do conhecimento; é a simples representação intelectual de um ser ou de uma coisa. O conceito [ou idéia] é a representação intelectual [ideal] de um ser ou de um objeto, sem, contudo, afirmar ou negar (...) o conceito é uma representação porque constitui um ato cognitivo; é simples, porque advém de um simples ato de espírito, sem afirmar ou negar [distinguindo-se, portanto, do juízo]; e é intelectual, porque é abstrato e geral, distinguindo-se da imagem que é a representação sensível dos objetos ${ }^{438}$.

Como conceito, tem-se uma moldura paradigmática que tenta abarcar em seu conteúdo tudo aquilo que corresponda à sua extensão de significado. Leciona Luigi Zoja que "o conceito (do latim cumcapere, pegar junto) nos permite aferir a realidade sem nos limitar ao objetivo individual que vemos, mas extraindo dela uma qualidade decisiva e segurando-a num tear teórico que pode tecer o objeto ao infinito"439.

E é exatamente o conteúdo definidor que nos interessa. Como indaga Roberto Andorno, o que significa, para o homem, o fato de ser uma pessoa e não uma simples

${ }^{438}$ ALVES, Alaôr Caffé. Lógica: pensamento formal e argumentação. São Paulo: Quartier Latin, 2005, p. 168.

${ }^{439}$ ZOJA, Luigi. História da arrogância: Psicologia e limites do desenvolvimento humano. São Paulo: Axix Mundi, 2000, p. 82. 
coisa ${ }^{440}$ Afinal, o que qualifica os seres humanos como pessoas? Ou, de outro modo, há humanos que não possuem os indicadores que os caracterizam como sujeitos morais?

Ben A. Rich, na esteira de Locke, ressalta que pessoa é um conceito que pode ser articulado, e não uma condição que existe na natureza e pode ser descoberta e encontrada $^{441}$.

Dessas reflexões decorre o fato de um conceito ser, acima de tudo, uma articulação linguística, que aponta para alguns limites, o que implica a separação entre no mínimo duas categorias essenciais: pessoas e não pessoas.

Sob esse aspecto, as definições e conceituações, mesmo científicas, podem não ser absolutamente neutras ou não apontar diretamente - e unicamente - para uma realidade existente no mundo sensível, palpável e comprovável.

As atividades de nomear e unir os nomes dos objetos não podem ser compreendidas como traduções diretas para o nível da linguagem daquilo que é captado através da visão, do tato, do olfato etc. Intenções, objetivos, desejos e conhecimentos prévios estão presentes quando o homem, seja ele cientista ou não, descreve e explica o mundo à sua volta. A linguagem é, portanto, mais que uma replicação do mundo. Os nomes e conceitos são convenções, correspondendo quase sempre a decisões explícitas e arbitrárias tomadas pelos cientistas $^{442}$.

Essa distinção, entre ser ou não ser pessoa, importará caso consequências diversas advierem da separação, especialmente na área jurídica. Cumpre perguntar se somente as pessoas são protegidas por uma ordem jurídica - e, em contrapartida, são sujeitos de deveres -, ou, ao contrário, os entes que não são qualificados como possuidores de determinados atributos, justamente por isso, receberão tratamento diferenciado do Direito. Nesse ponto, considerar-se pessoa poderia ser entendido como outro status.

${ }^{440}$ ANDORNO, Roberto. La distinction juridique entre les personnes et les choses à l'épreuve dês procréations artificielles. Paris: L.G.D.J, 1996, p. 39.

${ }^{441}$ RICH, Ben A. Postmodern personhood: a matter of consciousness. Bioethics, vol. 11, n 3/4, 1997, p. 208. "Eu começo esta análise com a argumentação de que John Locke estava correto quando escreveu, em Um Ensaio sobre o Entendimento Humano, que a 'personalidade é um termo forense'. Por isto eu entendo que ele quis dizer, entre outras coisas, que a personalidade é um conceito que articulamos em vez de uma condição que existe na natureza e que descobrimos" (tradução nossa). No original: "I begin this analysis with the contention that John Locke was correct when he wrote, in An Essay Concerning Human Understanding, that 'personhood is a forensic term'. By that I understand him to mean, among other things, that personhood is a concept which we articulate rather than a condition that exists in nature which we discover".

${ }^{442}$ VIDEIRA, Antonio Augusto Passos. Para que servem as definições? In: EL-HANI, Charbel Niño; VIDEIRA, Antonio Augusto Passos. O que é vida?: para entender a Biologia do século XXI. Rio de Janeiro: Relume Dumará, 2005, p.21. 
Deveras, aduz Tércio Sampaio Ferraz Jr. que

\begin{abstract}
a personificação do homem foi uma resposta cristã à distinção na Antiguidade, entre cidadãos e escravos. Com a expressão pessoa obteve-se a extensão moral de caráter de ser humano a todos os homens, considerados iguais perante Deus. No direito, assim, o homem é para o homem sempre pessoa, nunca objeto, vai dizer $\operatorname{Kant}^{443}$.
\end{abstract}

É curioso observar que, muitas vezes, quando se refere à ideia de "humano", o que se faz é, na verdade, referências aos caracteres da pessoa e não ao significado biológico em si. Destarte, expressões que conduzem à noção de humanidade e natureza humana refletem, no fundo, uma certa correspondência com as discussões subjacentes ao conceito de pessoa.

Joseph Fletcher, um dos autores que trouxe importantes contribuições a essa discussão, como a listagem do que denomina de "indicadores de humanidade", abaixo analisada, reconhece a dificuldade de se estabelecer uma definição, e declara que palavras recorrentes como os termos "humano" e "natureza humana" serão pântanos semânticos enquanto não se lograr êxito na obtenção de um consenso mínimo do significado de "homem" "444. Afinal, também às ciências médicas interessam definições sobre a extensão do significado de tal expressão, e o problema do aborto possibilita semelhante reflexão ${ }^{445}$. Enfoca-se, assim, o caráter convencional da língua, ao qual já referimos pouco acima. Aliás, vale ressaltar, as definições que utilizamos são convenções que muitas vezes servem para eliminar ambiguidades do discurso ${ }^{446}$.

Etimologicamente, o conceito de pessoa liga-se à ideia de um papel desempenhado pelo sujeito, a persona. Lembra Peter Singer que

a palavra 'pessoa' tem origem no termo latino que remete a uma máscara usada por um ator no teatro clássico. Ao usarem máscaras, os atores davam a entender

443 FERRAZ Jr., Tércio Sampaio. Introdução ao estudo do Direito: técnica, decisão, dominação. São Paulo: Atlas, 1994, p. 156.

${ }^{444}$ FLETCHER, Joseph. Humanhood: essays in biomedical ethics. New York: Prometheus Books, 1979, p. 8 .

${ }^{445}$ Ibid., p. 8.

${ }^{446}$ COPI, Irving M. Introducción a la lógica. Buenos Aires: Editorial Universitária de Buenos Aires, 1962, p. 93. "Outro propósito a que pode servir a definição é eliminar a ambiguidade. Talvez a maioria das palavras tem dois ou mais significados ou sentidos distintos, mas habitualmente isto não enseja nenhum inconveniente" (tradução nossa). No original: "Outro propósito al que puede servir la definición es eliminar la ambigüedad. Quizá la mayoría de las palabras tienen dos, o más, significados o sentidos distintos, pero habitualmente esto no origina ningún inconveniente". 
que estavam representando um papel. Com o passar do tempo, 'pessoa' passou a designar aquele que desempenha um papel na vida, alguém que é um agente ${ }^{447}$.

Essa noção liga-se, de certo modo, à de núcleos significativos, que merece tópico de análise específico.

Mais tarde, o termo foi apropriado pelo Cristianismo, para explicar a ideia da trindade do Pai, Filho e Espírito Santo, concebendo-se, no Concílio de Niceia, que aquela seria uma substância composta de três pessoas ${ }^{448}$. Assim, pode-se dizer que mesmo teologicamente, o termo pessoa não se identifica, simetricamente, ao que se considera homem biológico.

Joseph Fletcher, filósofo protestante, na linha de raciocínio que elabora - e que muito influenciaria Peter Singer -, estabelece com clareza que o "Homem" (man) não se equipara ao humano. Com isso, quer significar que há uma linha divisória importante entre o biológico e caracteres especiais que detalha em seguida, próprio das pessoas. Ou seja, é curioso observar que já em 1979 (ou mesmo antes, a considerar os termos zoé e bios), separavam-se com argúcia essas duas esferas que compõem o indivíduo, e que hoje podem chocar, sob o argumento de uma forma de totalitarismo calcado na arbitrariedade pura. Contudo, essa linha de raciocínio há de ser vista com uma reserva crítica.

${ }^{447}$ SINGER, Peter. Ética prática. São Paulo: Martins Fontes, 2002, p. 97.

${ }^{448}$ SINGER, Peter. Rethinking life and death: the collapse of our traditional ethics. New York: St. Martin's Griffin, 1996, p.180. Destaca o autor: "a palavra foi introduzida no discurso filosófico pelo filósofo estoico Epiteto, que usou-a para denominar o papel que alguém é chamado a exercer na vida. E foi tomada pelos primeiros pensadores cristãos lidando com o problema da compreensão da doutrina da trindade - qual era a relação entre o Deus-Pai, Deus-Filho e o Espírito Santo? Em 325, o Concílio de Niceia estabeleceu a questão dizendo que a trindade é uma substância e três pessoas" (tradução nossa). No original: "The word was introduced into philosophical discourse by the Stoic philosopher Epictetus, who used it to mean the role one is called to play in life. It was then taken up by early Christian thinkers grappling with the problem of understanding the doctrine of the trinity - what was the relationship between God the Father, God the Son, and the Holy Ghost? In 325 the Concil of Nicea settled the issue by saying that the trinity is one substance and three persons". Nesse sentido, vale retomar São Tomás de Aquino. AQUINO, Tomás de. Suma teológica. São Paulo: Loyola, volume I, 2001, p. 51. Na parte inicial e introdutória da obra, em que se expõem os conceitos basilares do filósofo, depreende-se que "uma das características da metafísica cristã é a descoberta da pessoa. A natureza aristotélica, certamente, só era concebível num sujeito concreto. Mas o valor da pessoa como tal não era percebido pela Filosofia antiga. O ápice do ser humano era a contemplação dos objetos inteligíveis superiores, os mais universais. Não havia reflexão sobre o ser individual que contempla e sobre o seu próprio valor; e, principalmente, não se via que o Inteligível supremo é ele mesmo uma Pessoa, a ser alcançada como tal". Walter Moraes (MORAES, Walter. Concepção tomista de pessoa: um contributo para a teoria do direito da personalidade. In: Revista de Direito Privado, $\mathrm{n}^{\circ}$ 2, 2000, p.191), por seu turno, escreve que "o uso da palavra persona para designar o indivíduo humano foi intrduzido pelo Direito Romano. Mas a pesquisa do conceito de pessoa como ente distinto do fisiopsiquismo humano (ausente em Aristóteles e na demais Filosofia grega) é iniciativa da filosofia patrística. A palavra personalitas, bem como o correspondente conceito, é criação exclusivamente escolástica. Ao tempo de Alberto Magno e Tomás de Aquino, o pensamento filosófico-teológico, organizado em Schola já há mais de três séculos e seguindo geralmente os padrões da Filosofia platônica, recebeu o contingente orgânico e metafísico do aristotelismo, e com ele novos e inusitados padrões de realismo, disciplina e exatidão racionais". 
Por certo, uma constatação que proceda à separação acima aventada não importa qualquer comando para que se faça ou deixe de fazer alguma coisa, em total menosprezo ao puramente humano (biológico). Muito ao contrário, isto possibilita uma ampliação cognitiva de análise. A vingar o argumento de que seria perniciosa semelhante distinção, boa parte das teorizações existentes no campo da Bioética estaria fadada ao ataque.

$\mathrm{Na}$ esteira de um relativismo ético, como defendido no capítulo terceiro, importa demonstrar a diversidade de pensamentos e de possibilidades. Isto significa também considerar como válida essa corrente de pensamento que toma como distintas a individualidade genética e a ontológica como pontos de partida para todas as discussões.

Nessa senda de investigações, Fletcher destaca que, apesar dos queixumes acerca da definição do que é o homem (aqui significando pessoa), pouco se vê uma tentativa clara de solução do problema. O que, é de se notar, torna-se mesmo paradoxal. Afinal, se a Medicina e o Direito estão às voltas com a proteção do homem e da pessoa, deveria surgir a dúvida de como o objeto de proteção deve ser compreendido.

Uma possibilidade, ao menos do ponto de vista jurídico, seria a estipulação de um marco específico - é o que verificamos no ordenamento jurídico brasileiro, em que se delimita como marco do início da personalidade jurídica o nascimento (artigo $2^{\circ}$ do Código Civil), sem se perquirir acerca de quaisquer outras notas do conceito de pessoa. Do ponto de vista dogmático, cuida-se de uma solução prática, com vistas à decidibilidade, o que não significa uma completa blindagem às críticas que surgem nem à interpretação que dá novo sentido num contexto mais amplo de regras. Aliás, é debate da ordem do dia a discussão sobre a pessoalidade do feto, que para alguns doutrinadores poderia ser apreendida de outras regras, como a salvaguarda dos direitos do nascituro, o que se nota especialmente em temas ligados ao direito sucessório, direito aos alimentos, entre tantos outros.

Por outro lado, pode-se partir da listagem de critérios para conceituação da pessoa, o que se nota com mais frequência no campo do raciocínio zetético e filosófico. É o que faz Joseph Fletcher, ao estabelecer uma série de indicadores do que se poderia denominar de "humanidade". Diríamos, nesse passo, que se trata de indicadores de "pessoalidade" e são enumerados pelo autor na ordem de quinze características básicas.

Peter Singer, ao retomar Fletcher, bem destaca a aproximação que o termo humano usualmente apresenta na ideia comum que temos de "ser uma pessoa". É o sentido das expressões que usamos para nos referirmos a um "verdadeiro ser humano" ou que demonstra possuir "qualidades verdadeiramente humanas". 
Ao fazermos tais afirmações, é evidente que não estamos nos referindo ao fato de a pessoa pertencer à espécie Homo sapiens, o que, enquanto fato biológico, raramente se coloca em dúvida; estamos querendo dizer que, caracteristicamente, os seres humanos possuem determinadas qualidades e que a pessoa em questão as possui em alto grau ${ }^{449}$.

Essas qualidades merecem atenção especial. Afinal, o que indicaria que o homem é, de fato, uma pessoa?

O primeiro indicador apontado por Fletcher seria um mínimo de inteligência. Utiliza o autor, como parâmetro, o QI, mencionando o teste Stanford-Binet: alguém com coeficiente inferior a 20 não seria pessoa. Como explica de maneira até lúdica, Homo, para ser pessoa, deve ser sapiens ${ }^{450}$.

Esse primeiro parâmetro utiliza um critério que pode ser questionado. Os testes que avaliam o mínimo de inteligência não necessariamente a indicam. Hoje discussões envolvem muitos outros aspectos, múltiplas formas de manifestação da inteligência, que ultrapassam as esferas ligadas ao estritamente racional, ligando-se a outras engenhosidades fabulosas do espírito humano, como as artes - o que justifica a aproximação dos enfoques teóricos e páticos para ampliação da percepção das inúmeras faces do abortamento.

Pode-se dizer, portanto, que esses testes são avaliativos de determinadas capacidades que outras espécies animais talvez não tenham, nem humanos em idade precoce, ou com sérias complicações e dificuldades intelectivas. Assim, esse critério traduzido como "mínimo de inteligência" espelha a capacidade da pessoa para certas ações, atividades, relações. Porém, não se trata do único critério trazido por Fletcher.

O segundo dos indicadores de humanidade (pessoalidade) citados por Fletcher é a autoconsciência (self-awareness/self-consciousness), cujo papel no desenvolvimento da personalidade é um dado básico da Psicologia ${ }^{451}$.

\footnotetext{
${ }^{449}$ SINGER, Peter. Ética prática. São Paulo: Martins Fontes, 2002, p. 96-97. O autor faz questão de separar os termos que se referem ao sujeito biológico e ao sujeito moral, abandonando, por conseguinte, a equiparação de "humano", nos sentidos apontados, e "pessoa". Como destaca, "a moralidade do aborto é uma questão fundamental, e a resposta que lhe dermos não pode depender de uma estipulação do modo como devemos usar as palavras. Para não incorrer em nenhuma petição de princípio e deixar claro o meu significado, por ora vou pôr de lado o melindroso termo 'humano' e substituí-lo por dois termos diferentes, que correspondem aos dois sentidos diferentes de 'humano'. Para o primeiro sentido, usarei simplesmente a expressão 'membro da espécie Homo sapiens', pesada e desajeitada, e, para o segundo, usarei o termo 'pessoa"”.

${ }^{450}$ FLETCHER, Joseph. Humanhood: essays in biomedical ethics. New York: Prometheus Books, 1979, p. 12.

${ }^{451}$ Ibid.,pp.12-13.
} 
Podemos conjecturar, quanto à autoconsciência, que se trata de qualidade própria de seres mais complexos na escala evolutiva biológica, o que está ligado, de fato, a certa especificação celular sistemática, como ocorre com os humanos, em que se encontra uma rede neural intrincada, o que, se não é consectário lógico da autoconsciência, ao menos é um indicativo de que essa qualidade está presente.

Do mesmo modo, Ben A. Rich, ao abordar especificamente a questão bioética do conceito de morte, considera que a personalidade, em termos pós-modernos, é uma questão de autoconsciência. O autor, depois de retomar o pensamento de Locke - que será tratado mais adiante - ressalta a importância fundamental da autoconsciência para definição da pessoa, e faz questão de destacar: não se trata meramente de consciência (consciousness), mas de autoconsciência (self-consciousness) $)^{452}$.

Destaca-se, nessas reflexões, a própria ideia de razão, como distintivo humano que ainda hoje é tomada como fator característico da espécie. Como ensina Tércio Sampaio Ferraz Jr.,

aos poucos, a razão acabou por tornar-se para o homem uma espécie de núcleo de sua própria natureza (animal rationale). Um valor em si que incorpora a própria dignidade humana, não constituindo um meio para obtenção de outros valores, mas o valor que dá sentido aos demais ${ }^{453}$.

Essa consciência das coisas e a autoconsciência, por conseguinte, ganham destaque quando tidas como atribuidoras de sentido ao mundo circundante, especialmente se considerada a capacidade criadora da linguagem. Escreve Reale, nessa senda, que

\footnotetext{
${ }^{452}$ RICH, Ben A. Postmodern personhood: a matter of consciousness. In: Bioethics, vol. 11, no 3/4, 1997, pp. 210-212. Como escreve o autor, "desenvolveu-se em Bioética uma importante distinção entre vida humana biológica e vida humana pessoal. Tal distinção é incompreensível fora da esfera dos seres com a capacidade não meramente para a consciência, mas para a autoconsciência. Além do mais, aqueles que colocam grande ênfase naquela distinção, como James Rachels e H. T ristam Engelhardt, cuidadosamente notam que estas duas dimensões da vida dos seres humanos não são coextensivas (...) o que é único sobre os seres humanos é sua capacidade para personalidade, para viver a vida autoconsciente de uma pessoa" (tradução nossa). No original: "there has developed in bioethics an important distinction between human biological life and human personal life. Such a distinction is unintelligible outside of the realm of beings with the capacity not merely for consciousness, but for self-consciousness. Moreover, those who place great emphasis upon that distinction, such as James Rachels and H. Tristam Engelhardt, carefully note that these two dimensions of the lives of human beings are not co-extensive (...) what is unique about human beings is their capacity for personhood, for living the self-conscious life of a person".

${ }^{553}$ FERRAZ Jr., Tércio Sampaio. Introdução ao estudo do Direito: técnica, decisão, dominação. São Paulo: Atlas, 1994, p. 352.
} 
o homem representa algo que é um acréscimo à natureza, a sua capacidade de síntese, tanto no ato instaurador de novos objetos do conhecimento, como no ato constitutivo de novas formas de vida. O que denominamos poder nomotético do espírito consiste em sua faculdade de outorgar sentido aos atos e às coisas, faculdade essa de natureza simbolizante, a começar pela instauração radical da linguagem (...) no centro de nossa concepção axiológica situa-se, pois, a idéia de homem como ente que, a um só tempo, é e deve ser, tendo consciência dessa dignidade. É dessa autoconsciência que nasce a idéia de pessoa, segundo a qual não se é homem pelo mero fato de existir, mas pelo significado ou sentido da existência $^{454}$.

Uma terceira característica basilar da pessoa diz respeito ao autocontrole. Sua ausência e a impossibilidade de correção de eventual disfunção ou anormalidade desse aspecto por meio médico retiram qualquer chance de se atribuir a alguém a qualidade de pessoa. Nesse passo, faz-se uma analogia a um protozoário, o paramécio ${ }^{455}$.

Atitudes meramente reflexas, regidas por mecanismos celulares ou reações involuntárias, excluiriam a caracterização como pessoa. É de se notar, ademais, que estados transitórios em que não estão presentes nem a autoconsciência nem o autocontrole não excluem o status de pessoa. Se assim o fosse, ao dormir ou ao se submeter a uma cirurgia com anestesia generalizada, a pessoa deixaria de existir. Essa reflexão tem como consequência a indagação acerca de casos em que persistem estados comatosos duradouros, de anos. Poderíamos pensar, num sentido filosófico, em uma pessoa? Qual o limite temporal fronteiriço entre uma hipótese e outra? Esse problema também toca a fundo as discussões sobre a eutanásia, em que muitas vezes, no centro do dilema, estão essas questões. Locke é uma fonte importante para compreensão desses debates, como se verá.

O quarto indicador de humanidade especificado por Joseph Fletcher é a noção de tempo (sense of time), ou melhor dizendo, de passagem do tempo. Esse senso estaria ligado ao chronos, e não ao kairos ${ }^{456}$. A ideia de passagem do tempo não deixa de ser uma abstração dentro da qual se insere a pessoa. É a consciência da sucessão temporal uma das características diferenciadoras entre ser ou não uma pessoa.

\footnotetext{
${ }^{454}$ REALE, Miguel. Filosofia do Direito. São Paulo: Saraiva, 1982, p. 211.

${ }^{455}$ FLETCHER, Joseph. Humanhood: essays in biomedical ethics. New York: Prometheus Books, 1979, p. 13. ${ }^{456}$ Ibid., p.13.
} 
As outras duas qualidades que seguem listadas em sua obra podem ser analisadas em conjunto, e dizem respeito, respectivamente, ao senso de passado e de futuro.

O senso de futuro, como explica Fletcher, relaciona-se à incrível capacidade de vislumbrar coisas que estão por vir, a vivência que ainda não é, mas que pode ser. A noção de devir não está presente noutros animais, que não têm, portanto, a ideia de existência futura. Nesse caso, para esses seres importa o momento atual, não existindo sentido ou percepção do porvir. Só se concebe o que é, nunca o que poderá ser, em termos temporais. A pessoa, ao contrário, é guiada por um viés denominado de teleológico ${ }^{457}$.

Também é esta noção de futuro, tipicamente presente nas pessoas, que possibilita planejamentos, estratégias, ponderações de consequências para os atos, tendo em vista o aprendizado acumulado. O mais incrível dessa qualidade é que a projeção dos acontecimentos torna possível a própria mudança do futuro. A pessoa, mais do que conceber o porvir, pode alterá-lo. Outros animais, ao contrário, pela falta de compreensão que ultrapasse o tempo presente, resignam-se ao curso dos acontecimentos, estando nele inseridos.

É bom destacar que não se incluem nessa noção de futuro meras reações automáticas; só em grau ínfimo, poderíamos pensar, incluem-se as relacionadas ao condicionamento, que não deixa de ter um componente "mecânico".

Por seu turno, a noção de passado (sense of past) liga-se à memória, que adquire um desenvolvimento excepcional nas pessoas, diferentemente do que ocorre em outras espécies, que se veem aprisionadas ao condicionamento. O motivo dessa capacidade relaciona-se ao desenvolvimento neural sofisticado presente nos humanos. Essa qualidade faz das pessoas seres culturais, e não simplesmente seres instintivos ${ }^{458}$.

Outro indicador apontado por Fletcher diz respeito à capacidade de se relacionar com os outros (the capability to relate to others). Nesse passo, podemos dizer que a pessoa humana é eminentemente comunicativa, no sentido de manter constantemente relações e estar em interação com outros, o que faz da comunicação ${ }^{459}$, na verdade, um outro critério de humanidade, na visão de Fletcher.

\footnotetext{
${ }^{457}$ Ibid., p. 13. Ressalva-se a capacidade de alguns primatas de conceberem-se numa linha temporal, como ensina Peter Singer, no livro Ética Prática, que mencionamos acima.

${ }^{458}$ FLETCHER, Joseph. Humanhood: essays in biomedical ethics. New York: Prometheus Books, 1979, pp. 13-14. "Memória. Diferentemente de outros animais, os homens alcançaram um nivel de desenvolvimento neurológico particulamente no cérebro e especialmente no neocórtex" (tradução nossa). No original: "Memory. Unlike other animals, men as a species have reached a unique level of neurological development, particularly in the cerebrum and specially its neocortex".

${ }^{459}$ SINGER, Peter. Rethinking life and death: the colapse o four traditional ethics. New York: St. Martin's Griffin, 1996, pp.181-182. Para Singer, a ideia de comunicação como caracterizador da pessoa não
} 
Dos animais afetos à sociabilidade, o homem merece destaque. Contudo, a capacidade de se relacionar com os outros não está ligada simplesmente à inserção num corpo social. Como lembra Reale, ao dissertar sobre a centralidade da pessoa como valorsíntese e sobre o elo existente entre pessoa e sociedade que conforma uma correlação primordial, há um vínculo de implicação e polaridade, de modo que o homem vale como homem na sociedade. Reale faz questão de destacar que "a sociedade é essencial à ‘emergência dos valores' (...) mas esta emergência é condicionada pelo valor transcendental e intrínseco do homem como tal ${ }^{\text {"460. }}$.

Existe um componente cultural inegável na construção das relações humanas, que são extremamente diversificadas. Uma mesma pessoa pode exercer diversos papéis - e isto ficará mais claro quando desenvolvermos a noção de núcleos significativos - , sendo cada papel um fio na rede de relações possíveis.

Ademais, é mister salientar que as relações interpessoais destacam-se por transcender a ideia de simples instinto animal. Este um fator diferenciador importante. Como seres gregários, as pessoas mantêm trocas que ultrapassam as necessidades meramente biológicas. Relembrando Aristóteles, pode-se dizer que o homem é um animal político (zoon politikon) ${ }^{461}$. Nesse passo, os componentes linguísticos das regras comunicativas adquirem destaque.

É de se sublinhar que o Direito, como objeto cultural, reflete a sociabilidade e a comunicação próprias das pessoas humanas. O conjunto de normas que compõem o

seria restrita aos animais humanos: outros também se enquadrariam na definição de pessoa, como algumas outras espécies de primata. Escreve que "há outras pessoas neste planeta. A evidência para a personalidade é atualmente mais conclusiva para grandes primatas, mas baleias, golfinhos, elefantes, macacos, cachorros, porcos e outros animais podem eventualmente também demonstrar que são conscientes de sua própria existência ao longo do tempo e capazes de raciocinar. Então eles também deverão ser considerados pessoas" (tradução nossa). No original: "there are other persons on this planet. The evidence for personhood is at present most conclusive for the great apes, but whales, dolphins, elephants, monkeys, dogs, pigs and other animals may eventually also be shown to be aware of their own existence over time and capable of reasoning. Then they too will have to be considered as persons".

${ }^{460}$ REALE, Miguel. Filosofia do Direito. São Paulo: Saraiva, 1982, p. 214.

${ }^{461}$ FLETCHER, Joseph. Humanhood: essays in biomedical ethics. New York: Prometheus Books, 1979, p. 14. Referindo-se à comunicação, escreve o autor: "alienação completa ou disconexão com os outros, se isto for irreparável, é desumanização. Isto não é tanto uma questão de não estar disposto a receber e enviar 'mensagens' mas sim a falta de habilidade para tanto. $\mathrm{O}$ critério é posto em questão em pacientes que não podem ouvir, falar, sentir ou ver os outros. Pode vir como resultado de trauma mental ou físico, infecção, desordem genética ou congênita, ou de causas psicológicas. Indivíduos completamente isolados são subpessoais. O problema é talvez mais familiar nos casos de doenças terminais e o tratamento clínico requerido" (tradução nossa). No original: "utter alienation or disconnection from others, if it is irreparable, is de-humanization. This is not so much a matter of not being disposed to receive and send 'messages' as of the inability to do so. This criterion comes into question in patients who cannot hear, speak, feel, or see others. It may come about as a result of mental or physical trauma, infection, genetic or congenital disorder, or from psychological causes. Completely and finally isolated individuals are subpersonal. The problem is perhaps most familiar in terminal illnesses and the clinical making required". 
ordenamento existe para disciplinar, em última instância, relações intersubjetivas, as trocas contínuas de mensagens entre um emissor e um receptor, o que, no Direito, torna-se expresso sob a ótica de uma teoria pragmático-jurídica da comunicação normativa.

Retomando a listagem das características próprias das pessoas, cita-se, ainda ligada às duas anteriores, a qualidade de preocupação com os outros (concern to others) ${ }^{462}$.

Podemos ponderar que essa qualidade está muito presente em inúmeras crenças e religiões, como o próprio Cristianismo, mas não só; ela implica certa alteridade, consideração ao próximo como reflexo dessa preocupação. É possível dizer que a própria noção de cuidado (ou ética do cuidado) e de minimização da dor e sofrimento em pacientes em estado terminal são desdobramentos bioéticos dessa característica apontada por Joseph Fletcher.

Outra qualidade da pessoa, para o autor, seria o controle da existência, pois não controlar algo enseja a irresponsabilidade, que não se coaduna com o ser propriamente humano. A vulnerabilidade extrema e a ignorância invencível, destaca o autor, são a antítese do que se pode denominar propriamente humano ${ }^{463}$.

A partir dessa característica, poderíamos, pois, excluir do conceito de pessoa todos aqueles que mantêm relação de dependência absoluta, não podendo, por si só, serem responsáveis. Estariam aí englobados desde o feto, que depende da mãe para sua nutrição e proteção, como também bebês e sujeitos com sérias enfermidades que não possuem desenvolvimento mental que os habilite a tomar conta de si mesmos. Assim, doença que comprometa o controle, ou falta de discernimento em razão do próprio desenvolvimento, constituiriam óbices ao reconhecimento da personalidade.

Uma pergunta que pode ser realizada, com relação a esse aspecto, diz respeito à inclusão no conceito de pessoa de todos aqueles que, transitoriamente, não possuem o discernimento para o controle de si. Um estado comatoso, por exemplo, faria com que alguém deixasse de ser pessoa? Na enumeração dessa qualidade, Fletcher é silente, e não aprofunda essas discussões tormentosas. Mas, por outro lado, se se responde que um estado transitório não excluiria alguém do enquadramento à pessoalidade, surgem novas questões, referentes ao lapso temporal que se relaciona ao "período transitório".

\footnotetext{
${ }^{462}$ Ibid., p. 14. "Se a preocupação com os outros é desinteressada ou inspirada por autointeresse destacado, parece claro que uma orientação extraego consciente é um traço da espécie; a ausência deste ambiente é uma indicação clínica de psicopatologia" (tradução nossa). No original: "whether concern to others is disinterested or inspired by enlightened self-interest, it seems plain that a conscious extra-ego orientation is a trait of the species; the absence of this ambience is a clinical indication of psychopatology".

${ }^{463}$ Ibid., p. 15.
} 
Outro atributo da pessoa seria a curiosidade. A busca por conhecimento e a perene necessidade de se perquirir o fundamento das coisas e a razão de ser dos acontecimentos são inerentes à pessoa. Ora, o acúmulo de descobertas e invenções - que têm um contributo criador humano - já demonstra alguns consectários da curiosidade. A indiferença, destaca Fletcher, seria inumana ${ }^{464}$.

Animais de outra espécie têm também certo senso de curiosidade. Mas pode-se dizer que não se trata de uma curiosidade prospectiva, tendo em vista alguma criação. É meramente instintiva, e muito ligada à exploração do ambiente em que vivem. A curiosidade humana, ao contrário, ultrapassa as relações de causa e efeito, apresentando a possibilidade de criação do próprio mundo. Ela explora e reinventa o ambiente, o dado: a curiosidade, nesse caso, apresenta um viés que se espraia na própria cultura. A pessoa humana cresce querendo saber, querendo descobrir, querendo experimentar.

$\mathrm{Na}$ sequência, podem ser citadas como características para a humanidade a mudança e a capacidade de mudança (changelchangeability). Essas qualidades devem ser compreendidas de modo amplo, englobando mais do que mudanças biológicas relacionadas ao crescimento e ao desenvolvimento ${ }^{465}$, pelas quais não apenas a espécie humana passa desde o nascimento, mas também os outros animais.

Em verdade, esses caracteres devem ser entendidos como possibilidade de mudança de conduta, de valores, pensamentos. A vida pessoal é dinâmica e, como um processo, é uma sucessão de acontecimentos sujeitos a reavaliações e mudanças, ocasionais ou refletidas. A estagnação e a consideração da vida como algo episódico afastam-se do conceito de pessoa.

Outra característica importante, especialmente considerando a metodologia adotada neste trabalho, diz respeito ao equilíbrio entre a razão e a emoção. Como salienta Joseph

\footnotetext{
${ }^{464}$ Ibid., p. 15. "Não ter afeto, afundado em anomia, não é ser uma pessoa. Indiferença é inumana" (tradução nossa). No original: To be without affect, sunk in anomie, is to be not a person. Indifference is inhuman".

${ }^{465}$ Ibid., p. 15. Destaca Fletcher: "na medida em que um indivíduo é imutável ou oposto à mudança, ele nega a criatividade dos seres pessoais. Isto significa não apenas o fato da mudança biológica ou psicológica, que segue numa condição da vida, mas a capacidade e disposição para mudar a mente de alguém e a conduta também. Biologicamente, os seres humanos são seres em desenvolvimento: nascimento, vida, saúde e morte são processos, não eventos, e devem ser compreendidos progressivamente, não episodicamnte" (tradução nossa). No original: "To the extent that an individual is unchangeable or opposed to change, he denies the creativity of personal beings. It means not only the fact of biological and physiological change, which goes on a condition of life, but the capacity and disposition for changing one's mind and conduct as well. Biologically, human beings are developmental: birth, life, health, and death are processes, not events, and are to understood progressively, not episodically. All human existence is a continuum, a matter of becoming".
} 
Fletcher, o "verdadeiro humano" não é nem completamente apolíneo, nem completamente dionisíaco $^{466}$.

Tendo em vista o critério anterior, mais uma vez destacamos nossa opção de uma análise interdisciplinar. Para compreensão dos problemas humanos (da pessoa, propriamente), é necessário um equilíbrio entre o Logos e o Eros.

De fato, os filmes auxiliam na compreensão de questões que não podem ser apreendidas em termos puramente racionais. Por certo, a dimensão afetiva está presente no momento de uma decisão acerca da interrupção da gravidez. Como apreender o problema em termos puramente racionais?

Essas duas facetas, razão e emoção, podem ser tomadas de modo complementar na vida humana, de maneira que onde uma solapa a outra, ou onde somente uma delas vigora, não se chega a bom termo.

Razão, na lição de Tércio Sampaio Ferraz Jr,

é um substantivo cuja origem está no verbo reri, que no significado primitivo queria dizer 'tomar algo por algo', portanto ligar 'coisas' entre si donde estabelecer relações e daí calcular, pensar (pesar, sopesar etc.). Quando os romanos traduziram por ratio a relação matemática (razão geométrica e aritmética) pensavam em logos, na cultura grega, um símbolo lingüístico que originariamente significava juntar, unir, pôr em conjunto; de onde surgiu logos no sentido de palavra (verbum), isto é, signo que sintetiza num som (fonema) vários significados. Daí logos equivale a ratio ${ }^{467}$.

Assim, poderíamos cunhar um neologismo, à semelhança daquele criado por Cabrera, e falar em uma perspectiva raciopática.

A penúltima qualidade própria do que se pode denominar pessoa é a idiossincrasia, isto é, a individualidade de cada qual. Em suma, trata-se dos contornos da identidade. ${ }^{468}$.

${ }^{466}$ Ibid., pp. 15-16.

${ }^{467}$ FERRAZ Jr., Tércio Sampaio. Introdução ao estudo do Direito: técnica, decisão, dominação. São Paulo: Atlas, 1994, p. 352; CHAUÍ, Marilena. Convite à Filosofia. São Paulo: Editora Ática, 1994, p.59. Escreve a autora que "logos, ratio ou razão significam pensar e falar ordenadamente, com medida e proporção, com clareza e de modo compreensível para outros. Assim, na origem, razão é a capacidade intelectual para pensar e exprimir-se correta e claramente, para pensar e dizer as coisas tais como são. A razão é uma maneira de organizar a realidade pela qual esta se torna compreensível. É, também, a confiança de que podemos ordenar e organizar as coisas porque são organizáveis, compreensíveis nelas mesmas e por elas mesmas, isto, as próprias coisas são racionais".

${ }^{468}$ FLETCHER, Joseph. Humanhood: essays in biomedical ethics. New York: Prometheus Books, 1979, p. 16. "Ser uma pessoa é ter uma identidade, e ser reconhecido e chamado por um nome" (tradução nossa). No original: "To be a person is to have an identity, to be recognizable and callable by a name". 
Deste modo, diz-se que a pessoa é irrepetível, pois não existem duas idênticas. Inúmeras são as particularidades que diferem os indivíduos e os tornam tão diferentes uns dos outros. Mesmo um código genético idêntico pode dar azo a personalidades completamente distintas.

Finalmente, o último indicador de pessoalidade trazido por Joseph Fletcher é a função neocortical (neocortical function). Trata-se, pois, de um marco cardinal para a delimitação de vida pessoal $^{469}$.

Em muitos casos, em pauta está a delimitação do momento da morte. Esse critério poderia ser tomado como balizador para estas discussões. Entenda-se por morte a irreversibilidade da perda dos estados cerebrais, e não mais o critério cardiorrespiratório.

Finalizando o item referente à humanidade (humaness), após apontar quinze indicadores de pessoalidade, Joseph Fletcher elenca cinco pontos (negative points) que não devem ser necessariamente atrelados à pessoa. Com isso, afasta algumas conclusões preconcebidas.

Em síntese, destacamos as cinco ideias trazidas. Segundo o autor o homem: a) não é não/antiartificial (os homens são caracterizados pela técnica); b) não é necessariamente parental, ou seja, a constituição de família não pode ser considerada da natureza humana, podendo alguém ser considerado pessoa mesmo sem que haja o aspecto reprodutivo, como ocorre em algumas ordens religiosas; c) não é essencialmente sexual, sendo que a sexualidade, na visão de Fletcher, é um fenômeno mais amplo e mais profundo do que o sexo; d) não pode ser considerado um "pacote de direitos". Com isso, quer-se assentar a ideia de que o fato de ser humano não pode ensejar conclusões automáticas de uma série de direitos preexistentes na natureza atribuídos aos homens, da maneira comumente feita, como se o homem, pelo simples fato de o ser, integrasse em si uma série de benefícios inatos, como a vida e o direito de se reproduzir. Afasta-se, portanto, a ideia de que os direitos são "absolutos, eternos e intrínsecos"; e) não é um adorador nato, isto é, a religiosidade não é da essência do ser pessoal. O sobrenatural e o místico são aspectos relacionados à crença, e não necessariamente uma escolha a ser realizada por todos os seres pessoais $^{470}$.

\footnotetext{
${ }^{469}$ Ibid., p. 16. "Antes da formação do cérebro, com o seu fim, na ausência de função de síntese do córtex cerebral, a pessoa é inexistente. Tais indivíduos são objetos, mas não sujeitos" (tradução nossa). No original: "Before cerebration is in play, or with its end, in the absence of the synthesizing function of the cerebral cortex, the person is nonexistent. Such individuals are objects but not subjects".

${ }^{470}$ Ibid., pp.16-18.
} 
Vale repetir: essas qualidades listadas por Fletcher não são critérios incontrastáveis e absolutos, mas podem ser tomados, sim, como diretivas para o estudo de um conceito de pessoa, aprofundando-o com os reparos críticos possíveis. Mesmo o autor, ao final da lista formulada, indaga acerca do modo de testar esses indicadores, reconhecendo que as questões atinentes à natureza humana são profundas e extremamente complexas. Ele não tem a pretensão de formular, portanto, uma lista definitiva e fechada, permanecendo aberto a correções $^{471}$.

Veremos outras maneiras de se conceituar a pessoa, mas, desde já, consideramos de grande valia algumas das conclusões do autor.

Faz-se necessário rumar às considerações de Locke sobre o conceito de pessoa, que corroboram alguns dos caracteres trazidos por Joseph Flecher, especialmente o caracter atinente à razão.

\subsection{O Conceito de Pessoa em John Locke}

$\mathrm{Na}$ obra de John Locke encontramos uma variedade de escritos que caminham desde a seara da Política até as trilhas da Filosofia. Nesta, podem ser tomados em consideração textos de relevante destaque para as discussões da Filosofia Moral e, por conseguinte, da Bioética.

É o caso da definição de pessoa, entendida por muitos autores como critério para compreensão do sujeito moral, do qual trata em seu Ensaio sobre o Entendimento

\section{Humano.}

As ponderações do filósofo que importam ao nosso estudo concentram-se basicamente no capítulo referente à identidade e à diversidade.

A inquietação trazida pelo autor enseja indagações referentes à identidade de um homem que, mesmo com uma constituição corpórea mutável, permanece uma pessoa. Para

\footnotetext{
471 Ibid., p.18. Como escreve: "estes são os critérios, mas como testá-los? E como compararemos e combinaremos os resultados de nosso criticismo? Como iremos ordenar ou dar prioridade aos itens em nosso perfil humano? Quais são os únicos ótimos, o que é essencial? Quais são as aplicações desses outros indicadores para as decisões normativas de médicos e biólogos? Na minha própria lista, quais fatores podem ser eliminados, totalmente ou em parte, sem minimizar os indivíduos e pacientes abaixo da linha pessoal? Eu confio que agora é claro que eu não pretendo ter produzido uma norma pura de humanidade. Eu permaneço aberto à correção" (tradução nossa). No original: "These are the criteria, but how are we to go about testing them? And how are we to compare and combine the results of our criticism? How are we to rank-order or give priority to the items in our man-hood profile? Which are the only optimal, what are essential? What are the applications of these or other indicators to the normative decisions of biologists and physicians? In my own list, here, which factors can be eliminated, in whole or in part, without lowering individuals and patients below the personal line? I trust that by this time it is plain that I do not claim to have produced the pure gospel of humanness. I remain open to correction".
} 
Locke, a identidade de um homem é a participação em uma mesma vida, ainda que a matéria seja fugaz ${ }^{472}$.

O questionamento assenta-se na permanência, apesar da passagem do tempo e de modificações físicas no corpo, de uma pessoa, da identidade dela mesma, que a faz reconhecida como aquele ser, aquele indivíduo, e não outro.

Por essas considerações, é possível constatar que Locke faz uma distinção entre corpo físico e "ser pessoa", de maneira que seria incorreto substituir um termo pelo outro. Ademais, o filósofo entende que há de ser realizada uma diferenciação entre três termos, quais sejam homem, substância e pessoa. Mas o que se nota, aponta o autor, é uma verdadeira confusão ${ }^{473}$; a dificuldade e obscuridade das discussões têm origem justamente pelo emprego inadequado das terminologias, o que dá azo às confusões.

Homem, na definição de Locke, liga-se à ideia de animal, como um corpo organizado que apresenta uma forma específica. Seria um signo que aponta para esta ideia (animal). Em suma, é um corpo vivo organizado ${ }^{474}$.

É a configuração do substrato físico, corpóreo, estritamente material, que, organizado de acordo com o comando genético contido nas células, adquire certa especificicidade. O signo homem indica, portanto, apenas uma das possíveis formas animais.

${ }^{472}$ LOCKE, John. Ensayo sobre el entendimiento humano. Buenos Aires: Fondo de Cultura Económica, 1956, pp. 314-315. Escreve o filósofo: "isso mostra também em que consiste a identidade de um mesmo homem, a saber: nada mais que a participação na mesma vida, continuada por partículas constantemente fugazes, e que nesta sucessão estão vitalmente unidas ao mesmo corpo organizado. Quem pretenda ligar a identidade do homem a qualquer outra coisa que não seja o mesmo que liga nos demais animais - quer dizer, em um corpo adequadamente organizado em um instante qualquer, e que, desde então, continua nessa organização vital por uma sucessão de várias partículas fugazes de matéria que estão unidas a este corpo -, terá dificuldade em fazer com que um embrião, um homem adulto, um louco e um sensato sejam o mesmo homem, por qualquer conjectura, da qual não se nega que é possível que Set, Ismael, Sócrates, Pilates, Santo Agostinho e César Bórgia sejam o mesmo homem" (tradução nossa). No original: "eso muestra también en qué consiste la identidad de un mismo hombre, a saber: en nada sino en la participación de la misma vida, continuada por partículas de materia constantemente fugaces, pero que em esa sucesión están vitalmente unidas ao mismo cuerpo organizado. Quien pretenda radicar la identidad del hombre en qualquiera outra cosa que no sea en lo mismo en que radica en los demás animales, es decir, en un cuerpo adecuadamente organizado en un instante cualquiera, y que, desde entonces, continúa en esa organización vital por uma sicesión de varias fugaces partículas de materia que están unidas a esse cuerpo, tendrá dificultad para hacer que un embrión, un hombre maduro, un loco y un sensato sean el mismo hombre, por cualquier suposición, de la cual no se siga que es possible que Set, Ismal, Sócrates, Pilates, San Agustín y César Borgia son el mismo hombre".

${ }^{473}$ Ibid., p. 315. "Uma coisa é ser a mesma substância, outra coisa é ser o mesmo homem, e outra coisa é ser a mesma pessoa, se é que uma pessoa, homem e substância são três coisas que significam três ideias diferentes (...)" (tradução nossa). No original: "una cosa es ser la misma substancia, outra cosa es ser el mismo hombre, y outra cosa ser la misma persona, si es que persona, hombre y substancia son tres nombres que significan tres ideas diferentes(...)".

${ }^{474}$ Ibid., pp. 315-316. 
Substância, por sua vez, diz respeito à matéria, às partículas fugazes que tomam parte na formação do homem.

Contudo, o que interessa não é unicamente essa identidade física, mas especialmente a identidade pessoal.

Daí surge o conceito de pessoa para Locke. Segundo o filósofo, pessoa é um ser pensante, inteligente, dotado de razão e de reflexão, e que pode considerar-se a si mesmo como uma mesma coisa pensante, não obstante a passagem do tempo, não importando o lugar em que esteja. Isto só é possível em virtude da razão, da consciência que, para Locke, é inseparável do pensamento ${ }^{475}$.

Concepção que de certa forma presta um tributo à de Locke é a de Jeff MacMahan, que utiliza o termo "para se referir a qualquer entidade dotada de vida mental de certa ordem de complexidade e sofisticação. De modo geral, para ser uma pessoa, deve-se ter uma capacidade de ser autoconsciente". ${ }^{476}$

Centra-se a definição de Locke na autoconsciência e racionalidade. No núcleo da ideia de pessoa, traz-se a capacidade de se tomar como entidade distinta no mundo, reflexivamente, o que significa um recorte entre os humanos, pois nem todos os homens, tal como o filósofo define, têm desenvolvida essa possibilidade racional, havendo aqueles com total desalinho à autorreferencialidade.

Lembra Singer, acerca dos escritos de Locke, que

\footnotetext{
esta definição aproxima 'pessoa' daquilo que Fletcher queria dizer com 'humano', salvo pelo fato de escolher duas características fundamentais - a racionalidade e a consciência de si - como âmago do conceito (...) muito provavelmente, Fletcher concordaria que essas duas características são essenciais e que as outras mais ou menos decorrem delas ${ }^{477}$.
}

Os animais não humanos, dessa forma, nunca poderiam ser considerados pessoas, pela falta de entendimento do próprio eu como entidade existente mesmo com o passar do tempo, em qualquer lugar. Daí a ideia de alguns autores, como Peter Singer, em considerar certos animais dotados de pessoalidade, a saber, outros primatas. Escreve o autor que

\footnotetext{
${ }^{475}$ Ibid., pp. 318-320.

${ }^{476}$ MACMAHAN, Jeff. A ética no ato de matar. Porto Alegre: Artmed, 2011, p. 18.

${ }^{477}$ SINGER, Peter. Ética prática. São Paulo: Martins Fontes, 2002, p. 97.
} 
"parece estranho chamar um animal de pessoa. Essa estranheza pode não ser mais que um sintoma do nosso hábito de manter a nossa espécie extremamente separada das outras"478.

Retomando o pensamento de Locke, põe-se em pauta como conciliar a consciência de si com o fator relacionado ao esquecimento, que faz com que a noção da própria existência seja constantemente interrompida.

Pode-se dizer que mesmo aqueles dotados de uma memória prodigiosa não são capazes de manter intacto o curso da própria existência, que é arranhado pelo esquecimento $^{479}$. Diante disso, com a passagem do tempo e o fato do esquecimento ser uma constante em nossas vidas, somos ou não a mesma coisa pensante? Somos ou não a mesma substância?

Em resposta a essa indagação, Locke esclarece que uma mesma pessoa e, portanto, uma só identidade pessoal, pode estar ligada a diferentes substâncias. Em suma, temos a mesma identidade, em que pese a sucessão de substâncias. Mesmo que haja esquecimentos, subsiste a consciência de ações passadas - que podem ser relembradas. A consciência pode ser compreendida, nesse ponto, como um elo de identificação pessoal ${ }^{480}$.

Podem causar certo estranhamento algumas conclusões do autor, se tomadas sem a compreensão de todos os tópicos que dedica ao tema. Uma dessas hipóteses pode ser assim descrita: como a pessoalidade está ligada ao fato de se ter consciência, o autor conjectura que, no caso de uma pessoa que sofre um acidente e fica com a memória tão seriamente prejudicada, de modo que se tornam incomunicáveis as consciências do passado e do presente, poderíamos concluir que um mesmo homem terá sido diferentes pessoas ${ }^{481}$.

\footnotetext{
${ }^{478}$ Ibid., p.119.

${ }^{479}$ LOCKE, John. Ensayo sobre el entendimiento humano. Buenos Aires: Fondo de Cultura Económica, 1956, pp.318-319. Escreve Locke que "esse ter consciência que se vê constantemente interrompido pelo esquecimento - já que em nenhum momento de nossa vida temos diante dos olhos em uma só visão todo o curso de nossas ações passadas, até os mais dotados de uma memória melhor perdem de vista uma parte deste curso ao olhar para outra, já que nós, algumas vezes, e isso na maior parte de nossa vida, não pensamos sobre nosso si mesmo passado, por estarmos ocupados com nossos pensamentos, ou pelo menos, nenhum que esteja acompanhado dessa consciência que adverte nossos pensamentos em estado de vigília" (tradução nossa). No original: "ese tener conciencia se vê contantemente interrumpido por el olvido, ya que em ningún momento de nuestra vida tenemos ante los ojos en uma sola visión todo el curso de nuestras acciónes pasadas, sino que hasta los dotados de mejor memória pierden de vista una parte de ese curso al mirar a outra, ya que nosotros algunas veces, y eso durante la mayor parte de nuestra vida, no reflexionamos sobre nuestro si mismo pasado, por estar ocupados en nuestros pensamientos, o por lo menos, ningunos que vayan acompañados de esa conciencia que advierte nuestros pensamientos en estado de vigília”.

${ }^{480}$ Ibid., p. 319.

481 Ibid., p. 326. "Sem dúvida, se é possível que um mesmo homem tenha, em diferentes momentos, consciências incomunicáveis e distintas, não há dúvida de que um mesmo homem seria deferentes pessoas em diferentes momentos" (tradução nossa). No original: "Sin embargo, si es posible que un mismo hombre tenga, em diferentes momentos, distintas e incomunicables conciencias, no hay duda de que un mismo hombre sería diferentes personas en distintos momentos".
} 
Deve-se ter em mente o fio condutor da razão e da consciência, que torna um homem uma pessoa. E essa consciência, apesar de por vezes interrompida na linha entre o presente e o passado, o que se dá pelo esquecimento, pode ou não ser retomada. No primeiro caso, há uma comunicabilidade entre o que era e o que o é, o que determina sua identidade. No segundo caso, quebra-se a ligação de memórias possíveis, que já não podem mais ser retomadas, ficando apartadas para sempre do momento presente.

Outra discussão interessante, que perpassa a seara da interrupção da consciência, diz respeito ao momento em que se está adormecido. Afinal, durante o sono, estabelece-se um período de apagamento da realidade e da consciência.

Sobre essa problematização, surge a ideia de pessoas incorporadas. Quem analisa a questão é H. Tristam Engelhardt Jr., segundo o qual, mesmo que o indivíduo durma, não é possível falar em uma quebra da identidade pessoal: as pessoas não são descontínuas. Contextualizando a ideia de Locke, haveria uma consciência de si que não se perde com o sono, e poderá ser retomada com o despertar. De fato, muitas vezes, ao acordar, o indivíduo é capaz de estabelecer inúmeras relações, como um sonho que teve e acontecimentos passados, o que corrobora ainda mais a unicidade pessoal.

Escreve H. Tristam Engelhardt Jr., a esse respeito, que

as mentes, que são finitas, espácio-temporais, e percebem pela sensibilidade, abrangem extensões espaciais e temporais como parte de sua própria condição. Sua incorporação é o seu lugar espacial e temporalmente situado neste mundo. O que podemos dizer por uma pessoa em tais circunstâncias não pode ser uma continuidade ininterrupta e de semelhança divina da autoconsciência. Em vez disso, é uma autoconsciência, como uma repetitiva integração de experiências que abrange descontinuidades, todas em um corpo espacialmente estendido. Esses seres precisam costurar juntos os seus vários episódios de vigilância e presença dentro de uma identidade única (...) o próprio sentido de uma pessoa humana compreende a unificação que faz de vários episódios temporalmente descontínuos em uma vida ${ }^{482}$.

${ }^{482}$ ENGELHARDT Jr., H. Tristam. Fundamentos da Bioética. São Paulo: Loyola, 2004, pp. 192-193. Mais adiante, o autor aprofunda essas discussões e diz: "uma autoconsciência incorporada, que alcança integração em uma auto-identidade experimentada, pode ser compreendida sem o recurso às pressuposições metafísicas ou à doutrina da potencialidade exigida para aqueles que afirmam que, como os fetos são pessoas em potencial, deveriam ser considerados pessoas. A questão não é se devemos considerar uma entidade que nunca mostrou as capacidades de uma pessoa como se fosse uma pessoa. A questão é saber como considerar uma entidade que intermitentemente mostra todas as capacidades de um agente moral. Como considerar essa entidade durante os períodos em que não mostra essas capacidades, mas quando se considera que ainda as tem (isto é, seu cérebro está intacto) e no futuro voltará a exercê-las?" 
A descontinuidade da consciência, se passageira, não dá azo à desconsideração do indivíduo como pessoa. Surge a distinção entre a potencialidade de se tornar uma pessoa e a potencialidade de retomar as habilidades de uma pessoa. Cuida-se de discussão interessante, à qual dedicaremos tópico específico.

Enfim, verifica-se, portanto, que ganha tônica no ideário de John Locke a centralidade da razão, crucial para a sua concepção de pessoa. Assim, cabe fazer uma pequena observação: o conceito de pessoa, em sua integralidade, não se reduz à razão, aos aspectos atinentes à consciência e entendimento de si mesmo como entidade destacada no tempo e espaço.

Destarte, como aponta Fletcher, os caracteres (indicadores de humanidade) que dizem respeito ao elemento racional são sim importantes, mas não são os únicos. Deve-se ter em mente que o conceito abrange aspectos relacionados à emoção e aos sentimentos, que se equilibram aos delineamentos da racionalidade. Essa ponderação prudente aparta-se dos extremos de instinto e de cálculo demasiado.

As criações humanas envolvem esses dois aspectos, sendo o mundo cultural em que se insere o homem uma projeção de autocriação estética, que envolve o balanceamento dos caracteres racional e emocional. Um não pode preponderar sobre o outro, em extremismos que se desqualificam mutuamente.

Razão e emoção, destaca-se, não são aspectos contraditórios da pessoa, mas complementares e necessários para o integral desenvolvimento da pessoalidade e da personalidade, não devendo ser antagonizados de forma maniqueísta. $\mathrm{O}$ homem racional, que tanta centralidade teve em outras épocas da história, deve ceder espaço ao homem integral, dotado de aspectos vários que se completam, como o sentimento.

Isso nos inspira nessa abordagem que toma a linguagem visual como problematizadora de muitas questões, que estão intimamente relacionadas ao Direito, como a interrupção da gravidez. A vantagem de aliar aspectos teóricos da Filosofia do Direito com as projeções da linguagem do cinema é exatamente a união dos dois aspectos citados, referentes ao Eros e ao Logos.

Com isso, concluímos ser mais interessante a indicação de Fletcher que, apesar de apontar elementos destacados por Locke, é muito mais ampla, e inclui no conceito indicadores outros, importantes para uma proposta de definição da pessoa. É, portanto, dentre as ideias até o momento analisadas, a que mais se aproxima de uma noção integral e multifacetada. 
Feitas essas considerações, importa examinar, ainda que brevemente, a noção de pessoa como um núcleo significativo, especialmente analisada por Tércio Sampaio Ferraz Jr., e que muito se liga à sua etimologia, qual seja a de máscara (persona), ou, noutros termos, papel social.

\subsection{Pessoa: a ideia de núcleos significativos}

Uma das ideias desenvolvidas na Teoria Geral do Direito como instrumental teórico é a de núcleo significativo.

Núcleos significativos são mecanismos de estabilização que os sistemas sociais desenvolvem, podendo apresentar características simples ou mais complexas, mais abertas e abstratas ou mais fechadas.

Na definição de Tércio Sampaio Ferraz Jr., citando Luhman, núcleos significativos são "centros integradores de sentido que conferem à variedade uma certa unidade aceitável para as interações sociais" ${ }^{\prime 483}$.

Entre esses mecanismos de estabilização, centros integradores de sentido, podem ser citados a pessoa, os valores, as ideologias, sendo o primeiro - o que nos interessa nesse instante - o mais simples de todos, mas que representa um instrumento importante para um universo de interações.

Destarte, tem-se que a pessoa "é um feixe de papéis sociais desempenhados por um indivíduo, papéis estes compondo uma unidade, de tal modo que um papel desempenhado afeta os demais papéis" 484 .

Para exemplificar essa noção de pessoa, que está imbricada à de papel social de um indivíduo, podemos mencionar uma situação hipotética em que alguém tenha uma família e filhos. Dentro dessa família, desempenha os papéis de esposo e de pai. Mas, fora desse núcleo familiar, assume outros papéis perante a sociedade, como o de pagador de impostos perante o fisco, o de membro de uma associação filantrópica ${ }^{485}$, amigo etc.

Assim, a pessoa é um mecanismo de união desses papéis institucionalizados que alguém exerce perante núcleos de convivência, seja em círculos mais restritos, como o ambiente doméstico, seja em meios mais amplos - como toda a sociedade, ou cada uma de suas interfaces.

${ }^{483}$ FERRAZ Jr., Tércio Sampaio. Introdução ao estudo do Direito: técnica, decisão, dominação. São Paulo: Atlas, 1994, p. 113.

${ }^{484}$ Ibid., p. 113.

${ }^{485}$ Ibid., p. 113. 
Como salienta Tércio,

conhecer a pessoa é, pois, conhecer sua história particular, os caracteres que ela imprime a todos os seus papéis e que dá consistência à sua ação. A integração deste complexo numa unidade pode ser mais ou menos coerente, podendo falarse, então, em diversos tipos de personalidade. Quando é possível, numa situação social, identificar a pessoa, estamos diante de um mecanismo capaz de integrar o sentido conteúdo da ação ${ }^{486}$.

Há, inegavelmente, uma perspectiva comunicacional, pois por detrás desses papéis institucionalizados, encontramos uma expectativa social diante de cada uma das figuras que alguém representa perante a sociedade. Por isso deve ser salientada a ideia de mecanismo que confere estabilidade às relações; é a maneira como conhecemos, ainda que de modo geral, cada um desses papéis sociais.

No exemplo trazido por Tércio, quando ficamos doentes, em geral procuramos um médico, e não um enfermeiro, pois, a princípio, consideradas as expectativas sociais sedimentadas, é o profissional adequado para o tratamento das enfermidades, ao menos institucionalmente. Porém mesmo a confiança socialmente estabilizada acerca do exercício de determinado papel social não é uma garantia de realização das expectativas. É o caso de uma cirurgia, que poderá não ser bem-sucedida, apesar de realizada por um profissional tecnicamente habilitado, o médico. Entretanto, o fato de o procurarmos "confere ao conteúdo da expectativa uma certa estabilidade: problema da medicina socializada e despersonalizada" ${ }^{487}$.

No âmbito relacionado ao gênero e à identidade, o assunto é abordado de maneira crítica por Judith Butler, que o questiona e leva a discussão aos papéis sociais do masculino e do feminino:

Seria errado supor que a discussão sobre a 'identidade' deva ser anterior à discussão sobre a identidade de gênero, pela simples razão de que as 'pessoas' só se tornam inteligíveis ao adquirir seu gênero em conformidade com padrões reconhecíveis de inteligibilidade do gênero $^{488}$.

\footnotetext{
${ }^{486}$ Ibid., p. 113.

487 Ibid., p. 114.

488 BUTLER, Judith. Problemas de gênero: feminismo e subversão da identidade. Rio de Janeiro: Civilização Brasileira, 2010, pp.37-38. Continua a autora: "Convencionalmente, a discussão sociológica tem buscado compreender a noção de pessoa como uma agência que reivindica prioridade ontológica aos vários papéis e funções pelos quais assume viabilidade e significado sociais. No próprio discurso filosófico, a noção
} 
Na seara do Direito, esses papéis sociais também aparecem com mais frequência do que se imagina, e cada indivíduo de certo modo reveste-se da máscara que o torna, numa dada situação, alguém que atuará de tal ou qual maneira. Em outros termos, é como se o indivíduo exercesse, em sua vida, a representação de diversas personagens, com funções próprias para cada papel.

É o caso dos papéis processuais, em que advogado, juiz, promotores de justiça e as próprias partes agem de determinada forma, cumprindo as funções atribuídas, ou atuando como socialmente se espera, o que acaba gerando, paradoxalmente, certa neutralização das relações pessoais, importando, no fundo, os papéis de cada um.

De fato,

por meio dos papéis nos identificamos uns aos outros. O sistema processual, nesse sentido, é um sistema de diferenciação de papéis que permite, a cada pessoa, agir como tal, mas através de papéis, impedindo que se relacionem, aparentemente como pessoas (...) a diferenciação dos papéis ocorre historicamente pela chamada configuração da auto-imagem ou autorepresentação e, normativamente, pela fixação de competências ${ }^{489}$.

Em situações mais complexas, no entanto, os papéis sociais são insuficientes como mecanismos garantidores de estabilidade. Nesse caso, recorrem-se a outros núcleos significativos, como os valores, que são mais abstratos e indeterminados, e indicam uma preferibilidade.

de 'pessoa' tem sido analiticamente elaborada com base na suposição e que, qualquer que seja o contexto social em que 'está', a pessoa permanece de algum modo externamente relacionada à estrutura definidora da condição de pessoa, seja esta a consciência, a capacidade de linguagem ou a deliberação moral. Embora não esteja aqui em exame essa literatura, uma das premissas dessas indagações é o foco de exploração e inversão críticas. Enquanto a indagação filosófica quase sempre centra a questão do que constitui a 'identidade pessoal' nas características internas da pessoa, naquilo que estabeleceria sua continuidade ou auto-identidade no decorrer do tempo, a questão aqui seria: em que medida as práticas reguladoras de formação e divisão do gênero constituem a identidade, a coerência interna do sujeito, e, a rigor, o status auto-idêntico da pessoa? Em que medida é a 'identidade' um ideal normativo, ao invés de uma característica descritiva da experiência? E como as práticas reguladoras que governam o gênero também governam as noções culturalmente inteligíveis de identidade? Em outras palavras, a 'coerência' e a 'continuidade' da 'pessoa' não são características lógicas ou analíticas da condição de pessoa, mas, ao contrário, normas de inteligibilidade socialmente construídas e mantidas. Em sendo a 'identidade' assegurada por conceitos estabilizadores de sexo, gênero e sexualidade, a própria noção de 'pessoa' se veria questionada pela emergência cultural daqueles seres cujo gênero é 'incoerente' ou 'descontínuo', os quais parecem ser pessoas, mas não se conformam às normas de gênero da inteligibilidade cultural pelas quais as pessoas são definidas”.

${ }^{489}$ FERRAZ J.r. Tércio Sampaio. Poder e direito. In: Estudos de Filosofia do Direito: reflexões sobre o poder, a liberdade, a justiça e o Direito. São Paulo: Atlas, 2009, p. 78. 
Após a análise sobre a noção dos núcleos significativos e o modo como a discussão se entrelaça ao conceito de pessoa, importa discorrer sobre a peculiar concepção de pessoa elaborada pelo jusfilósofo Hans Kelsen, em sua Teoria Pura do Direito.

\subsection{O conceito normativista de pessoa na Teoria Pura do Direito de Hans} Kelsen

Impende destacar, nesse item, a concepção juspositivista do conceito de pessoa trazida por Hans Kelsen em sua obra Teoria Pura do Direito, que é esboçada por ocasião do tratamento dado ao sujeito de direito.

Para compreensão desse conceito, é necessário ter em mente a postura metodológica do autor, sem o que causará espanto o entendimento "instrumental" do conceito de pessoa. Deveras, por afastar-se da ideia substancialista comumente considerada, Kelsen está caminhando nos trilhos de uma ciência do Direito purificada, à qual interessa a compreensão de seu objeto sem as interferências da Psicologia, da Sociologia, da Economia, da Política etc, ainda que considere todos esses aspectos possíveis no fenômeno jurídico: o Direito não é puro, e assim deve sê-lo a Ciência do Direito - como se depreende das páginas iniciais, em que se explicita o princípio da pureza.

A compreensão das ideias expostas na Teoria Pura do Direito acerca do conceito de pessoa requer, antes, o estabelecimento de algumas noções concernentes ao sujeito de direito.

O autor inicia o tópico relativo a essa questão fazendo uma precisa delimitação, separando o que considera sujeito de um dever jurídico e sujeito de um poder jurídico. Faz ainda um contraponto crítico com a teoria tradicional, e conclui:

num conhecimento dirigido às normas jurídicas não são tomados em consideração (...) os indivíduos como tais, mas apenas as ações e omissões dos mesmos, pela ordem jurídica determinadas, que formam o conteúdo das normas jurídicas $^{490}$.

Ao contrário das teorias tradicionais, que definem o sujeito jurídico com base na ideia de direito, Kelsen tomará este apenas reflexamente, de maneira que o dever é que tem

${ }^{490}$ KELSEN, Hans. Teoria Pura do Direito. São Paulo: Martins Fontes, 2009, p.189. 
a tônica central. Assim, dizer que existe um direito é entender a expressão "direito" apenas de maneira reflexa ao dever que é considerada a conduta oposta àquela que se torna pressuposto para se aplicar uma sanção.

Liga-se a noção de sujeito de Direito na teoria tradicional à própria ideia de direito subjetivo e, leciona Kelsen,

tal como neste conceito de direito subjetivo, também no de sujeito jurídico é decisiva a representação ou idéia de uma essência ou entidade jurídica independente da ordem jurídica, de uma subjetividade jurídica que, por assim dizer, preexiste ao Direito, quer no indivíduo, quer em algo coletivo, e que o mesmo Direito apenas tem de reconhecer e necessariamente deve reconhecer se não quer perder o seu caráter de 'Direito' 491 .

Desta maneira, não há como conceber, para Kelsen, a ideia de um sujeito de direito apartada do ordenamento jurídico. O que há é somente uma postura tradicional ideológica, que vê o indivíduo como alguém que tem um direito, sem que se considere o lastro do direito objetivo.

Portanto, consoante essa postura ideológica criticada por Kelsen, pode-se dizer que

a idéia de sujeito jurídico independente, na sua existência, de um Direito objetivo, como portador de um Direito subjetivo que não é menos "Direito", mas até mais, do que o Direito objetivo, tem por fim defender a instituição da propriedade privada da sua destruição pela ordem jurídica. Não é difícil compreender por que a ideologia da subjetividade jurídica se liga com o valor ético da liberdade individual, da personalidade autônoma, quando nesta liberdade está também incluída sempre a propriedade. Um ordenamento que não reconheça o homem como personalidade livre neste sentido, ou seja, portanto, um ordenamento que não garanta o direito subjetivo da propriedade - um tal ordenamento nem tampouco deve ser considerado como ordem jurídica ${ }^{492}$.

A esse respeito, retomando tal concepção ideológica de sujeito de direito atrelada à propriedade, esclarece Tércio Sampaio Ferraz Jr. que "a idéia de que se trata do portador

\footnotetext{
${ }^{491}$ Ibid., pp. 189-190.
}

492 Ibid., p. 191. 
do direito se reporta à liberdade no sentido de autonomia." E o homem tem no seu próprio corpo a primeira das propriedades (como ser que trabalha ou homo faber). ${ }^{493}$

Enfim, para Kelsen, só se pode falar em direito, propriamente, por conta do dever de outrem.

Após essa introdução acerca da noção de sujeito de direito, introduz-se a discussão acerca da pessoa, mais especificamente da pessoa física. Na teoria tradicional, há uma identificação entre ser pessoa e ser sujeito de direitos - já considerando todas as ponderações anteriores.

Escreve o autor que, na teoria tradicional, contrapõem-se as noções de pessoa natural (física) à pessoa jurídica, considerada como artificial, um construto teórico da ciência jurídica. Porém, "estas tentativas são tanto mais baldadas quanto é certo que uma análise mais profunda revela que também a chamada pessoa física é uma construção artificial da ciência jurídica, que também ela apenas é uma pessoa 'jurídica"” ${ }^{494}$.

A pessoa não é propriamente o homem, ser organicamente considerado. Não se pode identificá-los como equivalentes, tal como pretendem alguns jusnaturalistas e filósofos do Direito, que se mostram ainda extremamente apegados à substancialização. Aliás, mesmo a teoria tradicional "não nega que pessoa e homem são dois conceitos distintos",495.

Uma pessoa natural é tão normativa como a pessoa jurídica, denominada pelos cientistas do Direito como artificial. Com isso, erige-se um posicionamento polêmico, pois ocorre uma aproximação de duas categorias de pessoas tidas como absolutamente distintas, no que concerne à existência no mundo fenomênico ou em relação ao ordenamento jurídico.

Tanto é verdade que historicamente a alguns homens negou-se a titularidade de uma personalidade jurídica. Não que fosse negada a "humanidade" de determinados indivíduos, mas, por critérios estabelecidos pela ordem jurídica, determinados homens eram simplesmente excluídos de uma ordem de interações, sendo considerados tãosomente objetos de direito.

Com isso, ser ou não pessoa não equivale a uma reprodução de uma ordem natural, mas sim o estabelecimento normativo de critérios especificadores e de separação, que inclui alguns membros da sociedade como capazes de titularizar direitos e ser "portadores"

${ }^{493}$ FERRAZ Jr., Tércio Sampaio. Introdução ao estudo do Direito: técnica, decisão, dominação. São Paulo: Atlas, 1994, pp.155-156.

${ }^{494}$ KELSEN, Hans. Teoria Pura do Direito. São Paulo: Martins Fontes, 2009, p. 192.

495 Ibid., p. 192. 
de direitos e posições jurídicas, em contraposição àqueles a quem a mesma ordem jurídica nega essas posições.

Em conclusão, e ainda como contraponto à teoria tradicional,

$$
\begin{aligned}
& \text { a pessoa física ou jurídica que ‘tem’ - como sua portadora - deveres jurídicos e } \\
& \text { direitos subjetivos é estes deveres e direitos subjetivos, é um complexo de } \\
& \text { deveres jurídicos e direitos subjetivos cuja unidade é figurativamente expressa } \\
& \text { no conceito de pessoa. A pessoa é tão-somente a personificação desta } \\
& \text { unidade }^{496} \text {. }
\end{aligned}
$$

Consequentemente, tal conceito pode ser julgado como concepção normativista de pessoa, na medida em que é tomado como um centro que enfeixa um conjunto de normas e tanto a pessoa natural como a jurídica seriam ambas, em última instância, pessoas jurídicas.

\section{Esclarece Kelsen que}

dizer que o homem é um sujeito jurídico, isto é, sujeito de direitos e deveres, não significa - como foi expressamente acentuado acima - senão que a conduta humana é conteúdo de deveres jurídicos e direitos subjetivos, e, portanto, o mesmo que dizer que um homem é pessoa ou tem personalidade. $\mathrm{O}$ que em ambos os casos - tanto o da pessoa física como o da pessoa jurídica - realmente existe são deveres jurídicos e direitos subjetivos tendo por conteúdo a conduta humana e que formam uma unidade. Pessoa jurídica (em sentido estrito) é a unidade de um complexo de deveres jurídicos e direitos subjetivos. Como estes deveres jurídicos e direitos subjetivos são estatuídos por normas jurídicas melhor: são normas jurídicas -, o problema é, em última análise, o problema da unidade de um complexo de normas ${ }^{497}$.

Diferenciam-se, pois, as concepções estritas da noção de pessoa trazidas por H. Tristam Engelhardt Jr. e Hans Kelsen. Para o primeiro, trata-se de um conceito estrito de pessoa para se referir ao sujeito moral, em contraposição às concepções sociais de pessoa, delineadas por todos os indivíduos que apresentam certa deficiência intelectiva ou déficits de consciência (e autoconsciência). Para Kelsen, por sua vez, a concepção de pessoa em

\footnotetext{
${ }^{496}$ Ibid., pp. 192-193.

${ }^{497}$ Ibid., pp. 193-194.
} 
sentido estrito é a concepção de pessoa jurídica, considerada como unidade de direitos e deveres.

Enquanto para Engelhardt Jr. os fatores conectados à consciência grassam importância para a distinção que realiza entre um sentido estrito e um sentido social, para Kelsen, a interface de suas concepções é ditada pela unidade de uma pluralidade de normas.

Caberá ao ordenamento jurídico dizer quem é investido desse conjunto de direitos e deveres. Não se concebe, a priori, que todos os indivíduos ou entidades, como o feto e o embrião, sejam pessoas, mas poderão sê-lo à medida que forem tomados como unidade a enfeixar os direitos e deveres.

Exatamente por isso não se fala em uma identificação da pessoa a qualquer sentido natural verificável no mundo fático. A pessoa não é natural, uma substância, mas um centro de convergência normativa.

Em outras palavras,

\begin{abstract}
a unidade de deveres e direitos subjetivos, quer dizer, a unidade das normas jurídicas em questão, que forma uma pessoa física resulta do fato de ser a conduta de um e mesmo indivíduo que constitui o conteúdo desses deveres e direitos, do fato de ser a conduta de um e o mesmo indivíduo a que é determinada através destas normas jurídicas. A chamada pessoa física não é, portanto, um indivíduo, mas a unidade personificada das normas jurídicas que obrigam e conferem poderes a um e mesmo indivíduo. Não é uma realidade natural, mas uma construção jurídica criada pela ciência do Direito, um conceito auxiliar na descrição de fatos juridicamente relevantes. Neste sentido, a chamada pessoa física é uma pessoa jurídica (Juristische Person) ${ }^{498}$.
\end{abstract}

Assim, a pessoa, na teoria kelseniana, pode ser compreendida como um feixe de normas, um instrumental que reúne em si uma complexidade de situações jurídicas. Explica Karl Larenz que

como ‘puro conceito jurídico’ não se trata de um ente, de um ser físico ou psíquico ou - conceito que KELSEN não conhece - de um ser do espírito, mas de um complexo de deveres jurídicos e de direitos subjectivos, cuja unidade o conceito de pessoa permite exprimir figuradamente ${ }^{499}$.

\footnotetext{
${ }^{498}$ Ibid., p. 194.

${ }^{499}$ LARENZ, Karl. Metodologia da Ciência do Direito. Lisboa: Fundação Calouste Gulbenkian, p.102.
} 
Na crítica de Mario Emílio Bigotte Chorão, essa concepção de pessoa estaria incluída entre aquelas tidas como idealistas. Como escreve o autor,

a concepção idealista desloca, por assim dizer, a sede do direito para o pensamento e a vontade (ius in mente, ius in voluntate) e transfere para a lei ou para o sistema positivo a causa efficiens da personalidade jurídica. Esta passa a ser um produto racional, de caráter mais ou menos formal e abstracto, explicável como mero fenómeno cultural, à margem de qualquer fundamento natural e metafísico. Neste caso, a personalidade jurídica é, com toda a propriedade, a 'máscara' construída pelo sistema normativo e por este posta a quem bem entender, conforme o papel social que lhe pretende fazer desempenhar $^{500}$.

Importa analisar, ademais, outra concepção de pessoa, desenvolvida por São Tomás de Aquino: a concepção tomista de pessoa, que influenciou muitos escritores e por vezes é retomada nos dias atuais por opositores do aborto.

\subsection{Conceito tomista de pessoa ${ }^{501}$}

A Suma Teológica, de São Tomás de Aquino, é considerada um verdadeiro legado de aprofundamentos filosóficos que transcendem o campo da religião, deitando influência em várias discussões atuais, como as concernentes ao problema do aborto. Pode ser destacado, além das reflexões sobre a pessoa e a natureza humana, o pensamento sobre o ato e a potência.

É fato que o filósofo guarda em sua obra influência inegável de outros autores medievais e da Filosofia Antiga (podemos destacar, por exemplo, Aristóteles); no entanto, ele vai além em inúmeros aspectos, o que torna sua obra singular, destacada entre os pensadores de seu tempo e de outras épocas.

\footnotetext{
${ }^{500}$ CHORÃO, Mario Emílio Bigotte. Concepção realista da personalidade jurídica e estatuto do nascituro. Revista brasileira de Direito Comparado, $\mathrm{n}^{\circ}$ 17, Instituto de Direito Comparado Luso Brasileiro: Rio de Janeiro, 1999, p. 267.

${ }^{501} \mathrm{Um}$ artigo interessante sobre o assunto foi escrito por Walter Moraes, que analisa São Tomas e busca contextualizar os direitos da personalidade. Consultar: MORAES, Walter. Concepção tomista de pessoa: um contributo para a teoria do direito da personalidade. Revista de Direito Privado, $\mathbf{n}^{\mathbf{0}}$ 2, 2000.
} 
Destaca Carlos Josaphat, no prefácio à tradução brasileira, o sentido da Suma do filósofo medieval, ressaltando-se os caminhos de uma originalidade criativa. Segundo Josaphat,

joga-se de corpo e alma nesta proeza, jamais realizada antes ou depois dele, e que sua síntese quer levar a cabo: tecer uma Suma, em que se juntem e fraternizem a filosofia, concebida como leque completo do saber humano, a teologia, que enfeixa e ordena toda a tradição cristã, a ética pessoal e social, que estuda e articula os valores e modelos de plena realização do ser humano e da sociedade. E tudo vem coroado por uma mística da perfeita contemplação e união com Deus. Sem dúvida, como todo gênio, Tomás só podia contar com os recursos de seu tempo para tentar concretizar a audácia infinita desse projeto, que renasce sem cessar, solicitando todas as épocas e todas as gerações ${ }^{502}$.

Sua preocupação acerca da pessoa faz com que dedique tópico específico nas suas Questões, discorrendo pormenorizadamente sobre a maneira de compreensão do termo. Há, na Suma Teológica, uma desenvoltura de organização das ideias, que são classificadas a cada tópico, a cada ponto, e subdivididas de maneira a tornar clara a ordem de conceitos que se pretende expressar, num caminho que se torna lógico.

De fato, destaca Comparato que "todos os tratados teológico de São Tomás obedecem, rigorosamente, a esse método de oposição sistemática de argumentos, ordenados em vista de uma conclusão, que sobrevêm a modo de uma sentença judicial" ${ }^{\text {"503 }}$.

Assim, a questão número XXIX é subdividida para abordagem: a) do significado do termo pessoa; b) do número de pessoas; c) do que este número implica ou exclui; e d) do nosso conhecimento das pessoas. Por seu turno, o significado do termo pessoa é ainda delimitado pelo filósofo em quatro pontos: a) a definição do termo; b) a comparação do termo pessoa com os termos essência, subsistência e hipóstase; c) a aplicação do termo a Deus e, finalmente; d) o que o termo significa em Deus ${ }^{504}$.

${ }_{502}^{503}$ AQUINO, Tomás de. Suma teológica. São Paulo: Loyola, volume I, 2001, p. 14.

${ }^{503}$ COMPARATO, Fábio Konder. Ética: Direito, Moral e Religião no mundo moderno. São Paulo, Companhia das letras, 2006, pp.141-143. Completa o autor, dizendo que "o pensamento ético-teológico de São Tomás, todo impregnado de aristotelismo, é francamente racionalista. O primeiro e inabalável postulado do sistema é o de que o homem foi dotado pelo Criador da capacidade de separar a verdade do erro, mediante o uso da razão".

${ }^{504}$ AQUINO, Tomás de. Suma teológica. São Paulo: Loyola, volume I, 2001, p. 521. 
Interessa, para os fins deste trabalho, especialmente a definição de pessoa na compreensão tomista. Porém, isto não significa o abandono das outras discussões, que serão retomadas quando forem necessárias.

No início do primeiro artigo, referente à primeira das indagações da questão número XXIX, Tomás de Aquino toma a definição boeciana de pessoa e, para o pensador, parece comum não ser conveniente a definição de pessoa como substância individual de natureza racional ${ }^{505}$. Assim, parte o filósofo das críticas que são elaboradas ao conceito formulado por Boécio.

$\mathrm{Na}$ crítica primeira ao conceito de Boécio, a definição não exprimiria um sentido individual. E como pessoa é um ser individual, a acepção estaria equivocada. Além do mais, não está claro o sentido de substância empregado na definição. Não é só: haveria uma imprecisão ao adotar, conjuntamente a uma coisa real, uma intenção lógica; ou seja, pessoa como coisa real não poderia estar ligada a indivíduo, que designa um sentido lógico. Seria preferível, na verdade, o termo essência à substância para o conceito. Por fim, traz o autor a ideia crítica de que "a alma separada é um substância de natureza racional. Ela, no entanto, não é pessoa" ${ }^{, 506}$.

A essas críticas responde Tomás de Aquino. Em primeiro lugar, o termo individual é usado para designar o singular no gênero substância, e natureza racional para exprimir o singular nas substâncias racionais.

O conceito tomista de pessoa pressupõe a noção de substância. É, portanto, um substancialista, mas a ideia de substância é individual, singularizada. À denominação de substância individual dá-se o nome de hipóstase (hypostasis).

Como denomina São Tomás, hipóstase designa a substância primeira, sendo uma nomenclatura especial que se dá aos indivíduos.

A pessoa é uma substância individual, uma "hipóstase", como todos os indivíduos substanciais que compõem o universo real. Contudo, ela tem isto de singular, que a natureza que nela se realiza é uma natureza racional, o que lhe confere uma superioridade não somente de grau, mas de ordem, em relação a

\footnotetext{
${ }^{505}$ Ibid., p. 99. Consoante o vocabulário trazido na obra, a "substância é o ente (ver ser*) enquanto sujeito apto a existir por si. Existir por si (ou melhor, em si) não significa existir sem causa, nem ser a própria causa de sua existência. Significa ser o próprio sujeito do ato indivisível, e, por isso mesmo, ser constituído como um "ser em si". Isto se opõe a existir apenas como princípio constitutivo do que existe (a alma, a forma em geral) - ou como parte integrante de um todo existente, mas isso se opõe antes de tudo a existir-em-um-outro e por um outro, que é o modo de existir do acidente". E mais, "ainda que emprestado de Aristóteles, o conceito de substância foi tão freqüentemente usado em teologia (mistério da Trindade, da Encarnação, da eucaristia) que adquiriu uma importância e significação novas, extremamente complexas".

${ }^{506}$ Ibid., p. 522.
} 
todos os outros entes ou hipóstases, em relação a esse valor supremo, fonte e medida de todos os outros, o ser. Essa superioridade manifesta-se aqui pela prerrogativa da liberdade, apresentada como poder de dirigir-se a si mesmo, conduzir-se em vez de submeter-se passivamente, como os outros, às forças exteriores - que todavia agem também sobre ela, mas não sem que ela possa fazê-las servir ao cumprimento de seus desígnios. Com efeito, o agir manifesta o ser, de forma que uma superioridade de ordem no modo de agir é a conseqüência e o sinal de uma superioridade, mais profunda e mais importante no próprio ser ${ }^{507}$.

Há pois, no conceito tomista, um apelo à consciência - que se torna um indicador recorrente na definição da pessoa.

Quanto à segunda indagação, referente à comparação dos termos pessoa, essência, subsistência e hipóstase, São Tomas de Aquino, explicando em seguida todas as variantes terminológicas empregadas por alguns filósofos, diz que "parece que pessoa é o mesmo que hipóstase, subsistência e essência" "508. Porém explica que há sim uma diferenciação.

Ensina que substância possui dois sentidos. O primeiro deles equivale à quididade (o que os gregos denominam de ousia, e que se relaciona à essência das coisas). Em um segundo sentido, por sua vez, substância remete ao sujeito ou ao supósito que subsiste no gênero substância, o que se liga a outros três nomes ou expressões: ser da natureza, subsistência e hipóstase. Ou seja, a substância, nesse segundo sentido que Tomás de Aquino se refere, pode ser compreendida nesses três termos ou expressões. Subsistência, explica, é existir em si, e não em outro; ser da natureza refere-se ao sujeito de uma natureza comum; e hipóstase remonta ao sujeito dos acidentes. "O que estes três nomes significam em geral para todo o gênero de substâncias, o termo pessoa significa para o gênero das substâncias racionais"

507 Ibid., p. 523, nota do comentador "c". Como destacado nos comentários à Suma Teológica, "essa superioridade provém precisamente da racionalidade. Essa é a forma assumida pela intelectualidade em um espírito que só existe e age em um corpo e por seu intermédio: a esse título, traz com ela essa prerrogativa do espírito que do conhecimento deriva no agir: a consciência. Conhecimento e liberdade, eis o que segundo Sto. Tomás, caracteriza a pessoa, elevando-as acima de todos os entes que lhe são inferiores, justificando que a esse ente privilegiado, em que se concretiza uma natureza racional, dê-se um nome especial: "pessoa"'. Continua: "Assim, tanto quanto os modernos, Sto. Tomás define a pessoa pela consciência e pela liberdade. No entanto, censuram-lhe o fato de que comece a dizer que a pessoa é uma substância, e uma substância individualizada, não seria real, e todas as riquezas que evocam as palavras consciência e liberdade não seriam mais que uma idéia abstrata, seriam irreais, não pertencendo de fato a um ente. Em suma, para ser realmente um centro de consciência e uma fonte de liberdade, é-lhe preciso primeiramente ser: apenas as "substâncias primeiras" ou "hipóstases" são".

${ }_{508}$ Ibid., pp.525-527.

${ }^{509}$ Ibid., p. 526. 
Quanto à pergunta que faz acerca de dar nome de pessoa a Deus, vale destacar alguns dos apontamentos que se referem à própria origem da palavra. Retoma-se Boécio, que diz que o termo parece derivar de

máscaras que representavam personagens humanas nas comédias ou tragédias: pessoa, com efeito, vem de per-sonare ressoar, porque necessitava-se de uma concavidade para que o som se tornasse mais forte. Os gregos chamavam estas máscaras de prósopa, porque colocam-nas sobre a face e diante dos olhos para esconder o rosto ${ }^{510}$.

$\mathrm{Na}$ sequência, depois de explicitar os argumentos que negam a possibilidade de referir-se a Deus como pessoa, Tomás de Aquino refuta as ponderações trazidas por outros pensadores, de modo a conceber a possibilidade de semelhante referência a Deus. Aduz que

pessoa significa o que há de mais perfeito em toda a natureza, a saber, o que subsiste em uma natureza racional. Ora, tudo o que diz perfeição deve ser atribuído a Deus, pois sua essência contém em si toda perfeição. Convém, portanto, atribuir a Deus este nome pessoa. Não, porém, da mesma maneira como se atribui às criaturas. Será de maneira mais excelente ${ }^{511}$.

Por fim, quanto ao último item posto na questão XXIX - sobre se em Deus o termo pessoa significaria relação -, façamos algumas considerações. Por primeiro, tem-se que comumente dá-se à questão uma resposta negativa. Contudo, salienta São Tomás de Aquino que

o termo pessoa significa diretamente relação e, indiretamente a essência: entretanto, a relação não enquanto relação, mas enquanto significada à maneira de hipóstase. - E assim também a pessoa significa diretamente a essência, e indiretamente a relação, na medida em que a essência é idêntica à hipóstase, pois a hipóstase em Deus é significada a maneira de relação, entra de forma indireta na razão de pessoa $^{512}$.

${ }^{510}$ Ibid., p. 528.

${ }^{511}$ Ibid., p. 529.

${ }^{512}$ Ibid., pp. 532-533. Como se lê nas notas à Suma Teológica, "a Pessoa divina é uma relação e, como tal, distingue-se das outras Pessoas divinas, das quais cada uma é também uma relação, e que lhe é oposta; no entanto, essa relação é subsistente e, enquanto tal, identifica-se à única substância divina, à qual as duas 
Importa analisar, agora, a teoria sobre o conceito de pessoa desenvolvida por Michael Tooley, que, além de retomar alguns pontos teóricos de outros autores acerca da consciência, desenvolve a questão atrelada ao problema dos desejos para a importância de ser conferido a alguém o direito à vida.

\subsection{Michael Tooley e o conceito de pessoa: a teoria dos desejos e o direito à} vida

De relevante destaque na seara da Filosofia Moral que permeia a Bioética são os estudos de Michael Tooley, que se dedicou a temas como o aborto e infanticídio, escrevendo textos polêmicos, rebatidos ou adorados entre os estudiosos do assunto.

É necessário salientar que o autor passou por uma modificação de seu pensamento entre as suas obras sobre a temática. O artigo "Aborto e Infanticídio", cuja tradução portuguesa é utilizada nesse estudo, foi inicialmente publicado em 1972; posteriormente, o autor aprofundou algumas ideias sobre sua teoria dos desejos (que será abordada logo a seguir) em um livro de mesmo título, cujas ideias acompanham produções posteriores como a obra coletiva que aqui utilizamos.

A questão moral do aborto e do infanticídio, na visão do autor, parte das indagações acerca das propriedades que alguém deve apresentar para ser considerado uma pessoa e, consequentemente, ter o que chama de "forte" direito à vida. O autor também discorre sobre em que ponto do desenvolvimento algo adquire as propriedades que o torna uma pessoa.

O primeiro problema levanta uma questão moral. Solucioná-lo é decidir que princípios morais básicos relativos à atribuição do direito à vida devemos aceitar. O segundo problema levanta uma questão puramente factual, já que as propriedades em causa são propriedades puramente descritivas ${ }^{513}$.

outras também se identificam", e, "cada Pessoa divina, portanto, é rica de toda a realidade divina. É o Deus único, infinitamente perfeito, sábio, que ama, poderoso, mas cada uma o é de modo distinto. São Três a serem o único e mesmo Deus. A revelação da Trindade é a realização da revelação de Deus, inaugura no Antigo Testamento pela revelação de Javé Criador, Mestre da história, conduzindo-o ao termo que é o objeto da Promessa".

${ }_{513}$ TOOLEY, Michael. Aborto e infanticídio. In: GALVÃO, Pedro. A ética do aborto: perspectivas e argumentos. Lisboa: Dinalivro, 2005, pp. 76-77. 
À semelhança de outros autores, nota-se uma preocupação com a listagem de propriedades que algo deve ter para que possa ser considerado uma pessoa. A preocupação em definir os contornos de um sujeito que seja uma pessoa tem por consequência delimitar, em última instância, quem de fato possui direito à vida.

A controvérsia surge exatamente quando se conclui que fetos e bebês não possuem as propriedades que os tornem portadores de um direito à vida: não são, pois, pessoas.

Como outros autores, Tooley separa os termos "pessoa" e "humano", conferindo somente ao primeiro relevância em termos de equiparação a um sujeito moral em contraposição ao fato de o segundo somente pertencer à espécie Homo sapiens. Nesses termos, apenas uma pessoa teria direito à vida. Eis como se resolve, para o autor, o problema moral do aborto, que para outros remanesceria insolúvel.

Poderia se estabelecer, metaforicamente, a relação entre uma pessoa humana e um organismo. Para tanto, Tooley considera o caso de um monte de argila e uma estátua, o primeiro, correspondendo a um organismo e o segundo, a uma pessoa. A argila é constitutiva da estátua, mas não se identifica com ela. Do mesmo modo, qualquer mudança brusca e importante na constituição da estátua a tornará uma estátua diferente ${ }^{514}$. Os exemplos trazidos pelo autor, apesar de um tanto fantasiosos, ajudam a ilustrar as hipóteses aventadas.

\footnotetext{
${ }^{514}$ TOOLEY, Michael; WOLF-DEVINE, Celia; DEVINE, Philip E; JAGGAR, Alison M. Abortion: three perspectives. New York: Oxford University Press, 2009, p. 58. Escreve o autor: "Vimos que a ideia de que as pessoas humanas são idênticas a organismos é exposta a objeções decisivas (...) mas qual é a relação entre a pessoa humana e o organismo correspondente? A resposta é a mesma entre um monte de argila e uma estátua. Mas qual é a relação? Inicialmente, pode ser tentador identificar a estátua com o monte de argila do qual é composta, mas é claro que não pode ser correto, desde que, em primeiro lugar, o monte de argila pode continuar a existir depois que a estátua for destruída, e segundo, a estátua pode continuar a existir mesmo que todas as moléculas da argila original forem substituídas por outras moléculas. Muitos filósofos falaram da argila num dado momento com constituintes da estátua àquele tempo. Mudar o organismo de algumas maneiras - como, por exemplo, destruindo a parte superior do cérebro - e aquele organismo não mais constitui uma pessoa de verdade. Mudar o organismo de outro modo - reprogramando a parte superior do cérebro, ou substituindo-a por outra - e o organismo em questão não mais constitui uma pessoa" (tradução nossa). No original: "We have seen that the idea that human persons are identical with organisms is exposed to decisive objections (...) but what is the relation between a human person and the corresponding organism? The answer is that the same between a lump of clay and a statue. But what is the relation? Initially, it may be tempting to identify a statue with the lump of clay which it is composed, but it is clear that this cannot be right, since, first of all, the lump of clay may continue to exist after the statue has been destroyed, and second, the statue may continue to exist even if all of the original clay molecules in it are replaced by other molecules. Many philosophers speak of the clay at a given time as constituting the statue at that time. Similarly, a certain human organism at a time may constitute a human person at that time. Change the organism in certain ways - by, for example, destroying the organism's upper brain - and that organism no longer constitutes any person at all. Change the organism in other ways - by reprogramming the upper brain, or by replacing one upper brain with another - and the organism in question no longer constitutes the same person".
} 
A tese proposta é a de que "um organismo possui um forte direito à vida somente se possui o conceito de um eu enquanto sujeito contínuo de experiências e de outros estados mentais, e acredita que ele próprio é uma entidade contínua desse gênero" ${ }^{\text {} 515}$.

Essa concepção não é completamente inovadora, e repete, em termos, alguns dos indicadores elencados por Joseph Fletcher, que pontua a consciência de si e da existência como entidade individuada através do tempo e, enfim, senso de passado e futuro. Contudo, o matiz atinente aos desejos de um indivíduo representa o ponto de grande interesse no desenvolvimento de sua teoria.

O direito à vida, ou melhor, a atribuição de direitos em geral e de obrigações aos outros, estaria ligada ao desejo que pode ser aferido em um indivíduo. Em outras palavras,

atribuir um direito a um indivíduo é afirmar algo sobre obrigações prima facie que os outros indivíduos têm no sentido de agir, ou de se abster de agir, de certa maneira. No entanto, as obrigações em questão são condicionais, estando dependentes da existência de certos desejos do indivíduo a quem se atribui o direito $^{516}$.

Em primeiro lugar, a concepção de desejos está ligada aos estados de consciência. Não é possível conceber que seres inaptos dessa capacidade mental possam ter vontades. Vale ressaltar que ter direito a alguma coisa é, antes de tudo, ter a capacidade de desejar uma determinada situação que se liga ao direito. É o caso do direito à vida.

Não haveria, propriamente, um direito à vida, considerando o direito de um organismo puramente biológico, mas sim o direito de continuar a existir. Somente um ente com faculdades conscientes, na visão de Tooley, pode desejar existir, ou melhor, continuar sua existência como sujeito individuado no mundo - ao contrário daqueles que são completamente desprovidos desses caracteres.

Para Michael Tooley, a afirmação de que

\footnotetext{
"A tem direito a continuar a existir enquanto sujeito de experiências e de outros estados mentais" significa aproximadamente o mesmo que a afirmação "A é um sujeito de experiências e de outros estados mentais, A tem a capacidade de desejar continuar a existir enquanto sujeito de experiências e de outros estados mentais, e se A deseja continuar a existir enquanto entidade desse género então
}

515 TOOLEY, Michael. Aborto e infanticídio. In: GALVÃO, Pedro. A ética do aborto: perspectivas e argumentos. Lisboa: Dinalivro, 2005, p. 78.

${ }^{516}$ Ibid., pp. 78-79. 
os outros estão sob uma obrigação prima facie de não o impedir de continuar a existir" ${ }^{517}$.

O direito de viver, em outras palavras, estaria ligado ao desejo de viver. E, para que possa existir semelhante direito é necessário que o sujeito tenha experiência ou consciência daquilo que deseja, e que se compreenda como ente dotado desta capacidade de desejar (autoconsciente).

O problema, como adverte Tooley, são hipóteses que parecem excepcionar essa tese. Um primeiro caso, em termos de ilustração, é de alguém que, por uma perturbação psíquica, passe a sofrer de uma profunda depressão e, por conseguinte, queira morrer mais do que tudo.

Ora, nesse caso, não há como negar tal desejo. Deixaria de haver, pois, um direito à vida? Se respondermos que sim, que há um direito à vida a despeito do desejo expresso, a conclusão é de que o direito à vida não pode ser vinculado de maneira simples aos desejos de alguém.

Outra hipótese que é mencionada como crítica à doutrina dos desejos diz respeito aos casos em que alguém se encontra inconsciente, tal como no período em que se dorme, e, nesse caso, incapaz de desejar. Se ligarmos os direitos às vontades, não haveria que se falar em qualquer direito de alguém, assim, inconsciente.

Por fim, cita-se uma circunstância em que o desejo de alguém é distorcido e viciado por induções, como algumas crenças e seitas que induzem ao suicídio, criando na mente daqueles coagidos falsas convicções, que não condizem com o que se desejaria realmente.

Portanto, numa revisão à teoria dos desejos como delimitadora dos direitos, Michael Tooley esclarece que

o direito de um indivíduo a $\mathrm{X}$ pode ser violado não só quando ele deseja $\mathrm{X}$, mas também quando ele agora desejaria $\mathrm{X}$ caso não se verificasse uma das seguintes situações: (i) ele está emocionalmente desequilibrado; (ii) ele está temporariamente inconsciente; (iii) ele foi condicionado para desejar a privação de $\mathrm{X}$ (...) ter direito à vida pressupõe a capacidade de desejarmos continuar a existir enquanto sujeito de experiências e de outros estados mentais. Por sua vez, isto pressupõe possuirmos o conceito de uma tal entidade contínua e acreditarmos que nós próprios somos uma entidade desse género. Por isso, uma

${ }^{517}$ Ibid., pp. 80-81. 
entidade que careça desta consciência de si enquanto sujeito contínuo de estados mentais não possui o direito à vida ${ }^{518}$.

E nessa ideia reside o conceito de pessoa, que não se confunde com organismo humano. Para Tooley, o conceito em questão conecta-se, portanto, à capacidade de um ser de desejar a continuidade de sua existência. Enfim, como ressalta Peter Singer acerca da obra de Tooley "para ter direito à vida é preciso ter, ou, pelo menos, ter tido numa determinada época, o conceito de uma existência contínua" e

esta formulação evita quaisquer problemas relativos ao trato com pessoas adormecidas ou inconscientes; é suficiente que elas tenham tido, em alguma época, o conceito de existência contínua, pois isto nos habilita a dizer que a vida contínua pode estar entre os seus interesses ${ }^{519}$.

A partir disto se conclui que fetos não teriam direito à vida, pois nunca possuíram o conceito de um eu contínuo, sendo incapazes de desejar, portanto, a continuidade da própria vida.

Para Tooley, pensar que os fetos têm o direito à vida, por serem imbuídos do interesse de nascer, seria chancelar a continuidade de desejos ad infinitum, como o interesse no fato de que os pais tivessem se conhecido, pois sem isso, jamais haveria embrião.

Analisado o polêmico argumento de Tooley acerca do direito à vida, intrinsecamente ligado à possibilidade de consciência de si, e do desejo de continuar a existir, passaremos ao exame de uma concepção de pessoa que poderia ser compreendida como "biológica".

\subsection{A pessoa biológica}

Alguns autores identificam os termos "humano" e "pessoa", conforme vimos no capítulo precedente. A esta concepção, pode-se conferir a denominação de pessoa biológica, que empreende a visão substancialista, entre humanidade e pessoalidade. Também denominada de realista, essa concepção tem influência aristotélica e um de seus mais célebres precursores é David Wiggins, que critica a visão nominalista, por entender

\footnotetext{
${ }^{518}$ Ibid.005, pp. 82-84.

${ }^{519}$ SINGER, Peter. Ética prática. São Paulo: Martins Fontes, 2002, p. 108.
} 
ser extremamente complicada a elaboração de uma lista com as condições suficientes para ser pessoa $^{520}$.

Eugene Schlossberber define a pessoa biológica como um organismo funcional da espécie Homo sapiens, e esta ideia recebeu grande atenção nos escritos de Louis Agassiz, segundo o qual cada espécie distingue-se entre si e representa uma ideia da mente de Deus. Outros autores, por seu turno, entendem que a Terra como um todo representaria um organismo. Conclui Schlossberber que sua concepção de pessoa biológica, um pouco distinta das outras, é denominada de aristotélica: consiste na organização peculiar de processos digestivos, respiratórios, reprodutivos, entre outros, que conformam um parâmetro diferenciado, comparado às outras espécies ${ }^{521}$.

Norman Ford traz importante análise acerca da pessoa, que é por ele definida com base na natureza humana, que não pode ser considerada concepção estritamente biológica, mas que toma corpo como parte integrante do que se denomina pessoa. Segundo esse entendimento, não é possível separar, por exemplo, um cérebro do pensamento, da mente. Um é com o outro, de modo que refuta o dualismo corpo-mente que constitui, em verdade, uma unidade psicossomática. Assim, a pessoa é um ser humano individual que tem a possibilidade de praticar atos mentais e corporais, graças à natureza humana ${ }^{522}$.

O feto, nesse sentido, é considerado uma pessoa, pois possui uma natureza humana; assim, é somente uma questão de tempo para que possa desempenhar atos que fazem parte dessa sua natureza. Como Ford destaca, são pessoas com potenciais, e não pessoas potenciais, sendo irrelevante o fator de desenvolvimento de alguma anomalia congênita que limite a sua realização integral ${ }^{523}$.

Lança-se, nesses termos, uma crítica explícita aos autores utilitaristas, que falhariam em apreciar a ideia de natureza humana como um dos fundamentos da subjetividade da pessoa, ignorando que o embrião já é uma pessoa ${ }^{524}$.

\footnotetext{
${ }^{520}$ EVNINE, Simon J. Epistemic dimensions of personhood. Nova York: Oxford University Press, 2008, pp. 4-6.

${ }^{521}$ SCHLOSSBERBER, Eugene. Moral responsibility and persons. Philadelphia: Temple University Press, 1992, pp. 27-29.

${ }^{522}$ FORD, Norman M. The Prenatal person: ethics from conception to birth. Reino Unido: Blackell, 2002, p. 13. Mas, destaca Battista Mondin: "se o homem é só um corpo, só matéria, ele se torna necessariamente uma realidade manipulada, instrumentalizada e, portanto, não pode ter um valor absoluto, mas sim um valor instrumental; não mais simplesmente um fim, mas somente um meio". Nesse sentido, consultar: MONDIN, Battista. Definição filosófica de pessoa. Bauru: Edusc, 1998, p. 44.

${ }^{523}$ Ibid., pp. 13-16.

${ }^{524}$ Ibid., pp. 19-62. Isto não significa que o autor adote a tese de que a concepção seja um marco. Como vimos, em When Did I Begin, o escritor esboça uma interessante teoria acerca da individualização, da constituição do "ser ontológico".
} 
Enfim, Patrick Lee e Robert P. George, na ordem desses debates, criticam o dualismo que se estabelece entre corpo e pessoalidade (body-self dualism), como parcelas apartadas do ser humano - o que representaria um verdadeiro equívoco. Assim, acentua-se nesses autores a ideia de que o homem tem uma importância intrínseca e isto está ligado à própria natureza humana, e não a um atributo acidental, que permitiria denominá-lo como pessoa.

Ensina Comparato que

a concepção dualista do homem, como ser composto de alma e corpo em estado de perpétua tensão, resulta da confluência, no pensamento ocidental, da filosofia grega clássica e do judaísmo (...) Na Grécia clássica, a dissociação do ser humano no antagonismo entre alma e corpo atingiu seu ápice, como sabido, em Platão, e a partir dele confluiu com a vertente religiosa do cristianismo nascente, através dos primeiros Doutores da Igreja, notadamente Santo Agostinho (...) Já quanto ao dualismo da concepção do homem, no pensamento judaico, ele manifestou-se tardiamente, sem dúvida por influência do zoroastrismo. No cristianismo primitivo, a concepção dualista do homem foi muito evidente entre gnósticos e maniqueus. No maniqueísmo, sobretudo, a oposição metafísica entre o bem e o mal traduziu-se na idéia de perpétua tensão conflitiva entre corpo e alma, matéria e espírito; sendo o corpo evidentemente, a fonte de todo o mal ${ }^{525}$.

As discussões entre corpo e alma, suporte biológico e suporte espiritual, organismo e pessoa talvez estejam entre os temas da Filosofia Moral que mais se conectam à Bioética quando se tem em pauta o estabelecimento do direito à vida, ou a conformação do que poderia ser chamado de um agente moral, podendo ser retomadas, nesse ínterim, as teorias de Platão e Descartes. Para atacar essa diferenciação e repugnar a exclusão do feto como

${ }^{525}$ COMPARATO, Fábio Konder. Fundamento dos direitos humanos. Revista do Instituto de Estudos Avançados da Universidade de São Paulo, p. 12. Disponível em: http://www.iea.usp.br/textos/comparatodireitoshumanos.pdfv. Esse estudo dualista remete-nos também ao pensamento de Descartes. Na lição de Hilton Japiassu, "Descartes é o primeiro filósofo a proclamar esse dualismo marcando fundamente o pensamento ocidental: afirma alternadamentre o universo objetivo da res extensa (aberto à ciência) e o mundo subjetivo da res cogitans como dois mundos irredutíveis. A partir daí, a dualidade do sujeito e do objeto se põe em termos de disjunção, repulsa e anulação recíproca. Ao se encontrarem, ora é o sujeito ora é o objeto (o mundo) que se torna não-sentido. Há uma dissociação entre o mundo objetivo e o subjetivo regido pelo imperativo categórico da moral. No entanto, esses termos disjuntivos ou repulsivos, apesar de se anularem mutuamente, são inseparáveis: só há objeto relativamente a um sujeito que observa, define e pensa; e só há sujeito relativamente a um meio objetivo permitindo-lhe observar, definir, pensar e existir. Tomados isoladamente, são conceitos insuficientes. A idéia de mundo puramente objetivo (privada do sujeito, de contexto e de um além), repousando apenas no postulado da objetividade, é delirante e extremamente pobre" (JAPIASSU, Hilton. Desistir do pensar? Nem pensar!:criando o sentido da vida num mundo funcional e instrumental. São Paulo: Letras\&Letras, 2001, p. 25). 
pessoa, Patrick Lee e Robert P. George arquitetam uma conjectura que se aproxima das doutrinas analisadas por Norman M. Ford acerca da natureza humana.

Esses dois autores principiam por ressaltar que somos, antes de tudo, animais com uma continuidade (enduring animals), mas de modo contrário ao que pressupõem o mecanicismo (mechanist) e o perdurantismo e eventismo (perdurantism/eventism). Ou seja, existe uma unidade orgânica, que configura o agente que sente e atua, sempre conectado ao seu substrato físico-corpóreo. Não somos, portanto, meras partes agregadas (mecanicismo) ou uma coleção de eventos que se sucedem no tempo (eventismo) ${ }^{526}$.

Destarte, não há como proceder à semelhante distinção em termos de afastamento total, pois a inteligência - sua manifestação - dependeria da matéria e do corpo para expressar-se. N'outras palavras, há inteligibilidade no mundo material, e o intelecto humano não pode dissociar-se do corpo para realizar-se. Com isso, Lee e George partilham o entendimento de que a tônica da pergunta que se deve fazer é "o que é um ser humano?" num determinado momento, e não "o que faz/cria uma pessoa?" em termos temporais. A primeira indagação adere a uma perspectiva sincrônica do homem; a segunda, diacrônica, como os adeptos da tese de uma espécie de continuidade psicológica, como faz Locke - e que é severamente criticada pelos autores ${ }^{527}$.

Outra teoria que exsurge nesse debate diz respeito ao constitucionalismo concepção extremamente interessante desenvolvida por Lynne Rudder Baker ${ }^{528}$-, também criticado pelos autores em questão. Para tal corrente, não se nega que somos animais, mas as pessoas não se identificam com eles. Ou seja, apesar de sermos constituídos por uma forma e organização animal específicas, não existe a identidade entre um e outro. Constituição indica um elo mais fraco do que identidade. Mas Patrick Lee e Robert P. George argumentam que há evidências fortes de que a pessoa humana e o animal humano são a mesma substância. Ou seja, reforçam a tese de uma verdadeira pessoa biológica ${ }^{529}$.

\footnotetext{
${ }^{526}$ LEE, Patrick; GEORGE, Robert P. Body-Self dualism in contemporary ethics and politics. New York: Cambridge University Press, 2009, pp. 1-16. O perdurantismo, ou teoria das partes temporais, estabelece que a pessoa se perfaz com a união de uma série de estágios temporais (person-stages), e a continuidade psicológica da identidade pessoal implica, logicamente, o perdurantismo. Ver, nestes termos, p.29.

${ }_{527}$ Ibid., pp. 16-28.

528 BAKER, Lynne Rudder. When does a person begin?. Disponível em: http://people.umass.edu/lrb/files/bak05wheaP.pdf, Acesso em: 18 de junho de 2011. A autora desenvolve estudos intrinsecamente relacionados a estas questões, referentes ao dualismo - ou não - entre corpo e identidade pessoal. A ideia central é que as pessoas são constituídas por organismos. Publicado também nos seguintes periódicos: In Ellen Frankel Paul, Fred D. Miller, Jr, and Jeffrey Paul, editors, Personal Identity, pages 25-48. Cambridge University Press, Cambridge, 2005. Reprinted from Social Philosophy and Policy 22 (2005):25-48.

${ }_{529}$ LEE, Patrick; GEORGE, Robert P. Body-Self dualism in contemporary ethics and politics. New York: Cambridge University Press, 2009, pp. 38-44.
} 
Mas, se somos animais, o que nos diferenciaria de outras espécies? Para responder a esta indagação, Lee e George lançam mão do que chamam de pensamento conceitual, que é a capacidade de praticar ações que manifestam a transcendência da matéria, o que outros animais não conseguem fazer, já que se liga à compreensão, ao entendimento (understanding), como as diversas expressões tipicamente humanas ligadas à arte, religião, arquitetura, enterro dos semelhantes, agrupamentos sociais diferenciados, linguagem sintática etc ${ }^{530}$.

Contudo, a importância e dignidade humanas não dependem do integral desenvolvimento dessas habilidades, mas simplesmente do fato de possuirem uma natureza humana e uma capacidade para tanto, que é inerente à espécie. $\mathrm{O}$ atributo de ser uma pessoa, caso dependesse da aquisição de certa racionalidade - como expressamente argumentam autores da estatura de Peter Singer -, ensejaria uma distinção odiosa entre os seres humanos, conforme uma qualidade que não é essencial, a racionalidade (e a inteligência), havendo, mesmo entre os racionais, diferenças de valor de acordo com o grau de desenvolvimento dessa capacidade. Assim, a importância e os valores não devem depender de um atributo que varie em graus: daí a eleição da natureza humana e a capacidade de desenvolvimento que se revelam as mais adequadas para análise das questões morais ${ }^{531}$.

O pensamento de Lee e George, com essa consideração acerca do conceito de pessoa, enseja uma visão pró-vida com relação ao aborto, que será considerado um ato imoral, pois põe fim à pessoa biológica que se desenvolve desde a concepção, que é dotada de uma natureza humana. Fetos e embriões são pessoas completas, com valor moral inconstestável, porém ainda imaturas ${ }^{532}$.

Essa visão da pessoa biológica, sob o argumento da dignidade intrínseca da vida que possui uma natureza animal racional, afasta por completo qualquer discussão atinente à possibilidade de se praticar o aborto.

$\mathrm{Na}$ análise da identidade sob o crivo biológico, ou seja, numa consideração da pessoa em termos biológicos, Jeff MacMahan faz uma observação trazendo à baila a aplicação do conceito lógico de "sortal", que pode ser distinguido entre temporários, ou seja, de fase (phase sortal), e substanciais (substantive sortal):

\footnotetext{
${ }^{530}$ Ibid., pp. 50-56.

${ }^{531}$ Ibid., pp.81-94.

${ }^{532}$ Ibid., pp. 118-150.
} 
Um sortal temporário designa um tipo ao qual o indivíduo pode pertencer ao longo de somente uma parte de sua história (...) Um sortal substancial, por outro lado, designa um tipo ao qual um indivíduo pertence necessariamente ao longo de toda a sua existência ${ }^{533}$.

Com base nisso, conclui, de maneira a explicitar sua concepção sobre a pessoa:

\begin{abstract}
se o 'organismo humano' se aplica a nós como uma substância sortal, indicando o tipo de coisa que somos essencialmente, então 'pessoa' deve ser um sortal de fase. Pois está claro que organismos humanos começam a existir antes que adquiram uma vida mental suficientemente complexa para permitir-lhes que tenham a qualificação de pessoas, e é igualmente claro que eles podem perder a capacidade para autoconsciência, e, portanto, cessar de ser pessoas, e, não obstante, não só continuar a existir, mas também continuar vivos e conscientes $^{534}$.
\end{abstract}

Impende agora estudar algumas das controvérsias que erigem em torno do aborto tomando por fundamento a ideia de pessoa potencial.

\title{
5.8. A pessoa potencial
}

Já virou tradição, seja em escritos estritamente jurídicos, seja nos estudos bioéticos, certo tipo de argumento que considera os fetos e embriões implantados como pessoas em potência ou pessoas potenciais.

Contudo, conforme adverte Jeff MacMahan que

a alegação de que o feto é uma pessoa em potencial, ou que ele possui o potencial para tornar uma pessoa, é ambígua. Há pelo menos três maneiras possíveis de interpretá-la (...) Em primeiro lugar, a alegação pode querer dizer que o feto a partir do qual me desenvolvi não era eu, mas tinha o potencial para tornar-se eu (...) Em segundo lugar, a alegação de que o feto é uma pessoa em potencial talvez seja mais comumente entendida como querendo dizer que, embora eu tenha existido uma vez como feto, eu não era, naquele momento, uma pessoa, e, consequentemente, o meu estatuto moral era diferente do que é agora. Compreendida dessa forma, a alegação pressupõe que não somos

${ }^{533}$ MACMAHAN, Jeff. A ética no ato de matar, Porto Alegre: Artmed, 2011, p. 18.

${ }^{534}$ Ibid., p. 36. 
essencialmente pessoas (...) Em terceiro lugar, a alegação é muitas vezes interpretada significando que o feto, no seu estado atual, é uma pessoa incompleta, uma pessoa no processo de vir a ser, uma entidade cuja natureza essencial consiste em evoluir até tornar-se uma pessoa completa ${ }^{535}$.

A ideia subjacente ao argumento de defesa da vida atinente à consideração de pessoa potencial liga-se a uma expectativa natural de desenvolvimento, de um processo contínuo que se iniciaria com a concepção e continuaria durante as diversas fases embrionárias de um sujeito, o nascimento ulterior e o crescimento após a mudança de ambiente (com o parto).

Warren Quinn, utilizando nomenclatura um pouco diversa, defende a ideia de gradualismo, que podemos considerar parelha à de continuidade de desenvolvimento de um indivíduo desde a concepção.

De acordo com o gradualismo, 'a passagem à existência de indivíduos substanciais pode ser um processo temporal genuíno durante o qual o indivíduo em potencial passa a existir gradualmente, entrando no mundo aos poucos. A ontologia em questão envolve, portanto, a idéia de uma proporção em que um indivíduo se tornou plenamente efetivo, ou real, em um determinado momento, ou [...] de um grau em que ele já existe plenamente ${ }^{, 536}$.

Por isso diz-se que a o sujeito está inserido num continuum vital, cujas fases estariam intrinsecamente ligadas, não podendo ser feita divisão arbitrária de importância tendo por base o nascimento. Em outras palavras, o feto será o bebê, que será a criança, que será o adulto. É, pois, uma pessoa potencial, que deve ser respeitada e protegida contra as agressões, possuindo um direito de viver como o de qualquer indivíduo já nascido.

$\mathrm{Na}$ lição de Peter Singer, trata-se de um argumento que ele denomina de conservador:

os conservadores chamam a atenção para o continuum entre o óvulo fertilizado e a criança e desafiam os liberais a apontar qualquer estágio desse processo gradual que assinale uma linha divisória moralmente significativa. A menos que tal linha exista, dizem os conservadores, devemos conferir ao embrião o status de criança, ou fazer com que esta tenha o seu status reduzido ao de um embrião;

\footnotetext{
535 Ibid., p. 318.
}

${ }^{536}$ Ibid., p. 293. 
mas ninguém quer permitir que as crianças sejam mortas a pedido de seus pais e, assim, o único ponto de vista defensável está em assegurar ao feto a proteção que asseguramos à criança ${ }^{537}$.

Utiliza-se uma inferência lógica, segundo aquilo que costuma acontecer: fetos se desenvolvem e nascem. Cuida-se de traçar uma linha de acontecimentos praticamente inexorável, cujo curso se segue naturalmente, a menos que ocorra alguma interrupção que poderá ser considerada não natural e, portanto, comumente censurada. Como mostrado no capítulo anterior, há os argumentos que se valem da forma lógica silogística para demonstração do erro em tirar a vida de um embrião ou de um feto, apelando à ideia de pessoa em potência.

$\mathrm{O}$ argumento da potencialidade pode ser analisado tomando-se por parâmetro os ditames do Jusnaturalismo, especificamente as doutrinas que entabulam em seu raciocínio a concepção teleológica da natureza, na qual se insere o homem.

De acordo com esse pensamento, há um direcionamento natural para que o ser humano atinja um fim ótimo, de acordo com o que concebeu a natureza. Nessa esteira, escreve Hart que "cada espécie concebível de coisa existente, humana, animada ou inanimada, é pensada não só como tendendo a manter-se a si mesma em existência, mas como dirigindo-se para um estado definido óptimo que é o bem específico" ${ }^{\circledR 3}$.

Ora, nos argumentos reiteradamente expendidos pelos contendores que ferrenhamente defendem a potencialidade do feto apta a atingir a maturidade de uma criança e de um adulto, certamente está oculta esta ideia propalada pelo Direito Natural acerca do desenrolar das coisas de acordo com uma finalidade, um fim ótimo, que não pode ser interrompido - justamente por ser contrário à natureza das coisas.

Mesmo assim, a noção daquilo que pode ser compreendido por finalidade deixa um rastro de ambivalência, pois o atingimento dos fins últimos deixa obscuro se essa empreitada é dirigida, de algum modo, por algum princípio racional e consciente.

Deveras, alerta Hart que

uma das dificuldades na compreensão de uma visão teleológica da natureza reside em que, tal como minimizava as diferenças entre afirmações do que acontece regularmente e afirmações do que devia acontecer, também minimiza a diferença, tão importante no pensamento moderno, entre os seres humanos com

\footnotetext{
${ }^{537}$ SINGER, Peter. Ética prática. São Paulo: Martins Fontes, 2002, p. 148.

${ }^{538}$ Hart, Herbert L. A. O conceito de Direito Natural. Lisboa: Fundação Calouste Gulbenkian, 2007, p. 205.
} 
uma finalidade própria que conscientemente se esforçam por realizá-la e outros seres, vivos ou inanimados. Isto porque, na visão teleológica do mundo, o homem, como as outras coisas, é pensado como tendendo para um fim óptimo específico que está preparado para ele e o facto de que ele, diferentemente das outras coisas, pode para aí tender conscientemente, não é concebido como uma radical diferença entre o homem e o resto da natureza. Este fim humano específico ou bem é em parte, como o de outros, seres vivos, uma condição de maturidade biológica e de capacidades físicas desenvolvidas; mas também inclui, como seu elemento humano distintivo, um desenvolvimento e uma excelência de espírito e de carácter manifestados no pensamento e na conduta. Diferentemente das outras coisas, o homem é capaz, através do raciocínio e da reflexão, de descobrir o que envolve o alcance desta excelência de espírito e de caráter e é capaz de desejar. Contudo, mesmo assim, nesta visão teleológica, este estado óptimo não é o bem do homem ou seu fim, porque ele deseja-o porque é já o seu fim natural ${ }^{539}$.

Ora, não é possível aventar qualquer consciência teleológica nos estágios iniciais do desenvolvimento embrionário e fetal. Óbvio que o programa inserido nos códigos genéticos fará a leitura das mensagens transmitidas pelos ascendentes, determinando a manifestação dos caracteres, o crescimento e desenvolvimento. Mas, neste aspecto, a menos que se apele para uma força externa e metafísica, não há muita diferença entre as espécies, inclusive os vegetais. Assim, não é possível apegar-se à concepção teleológica, mesmo em seu aspecto da sobrevivência humana, para daí sacar um místico direito à vida, ou mesmo a transfiguração do ser em desenvolvimento numa pessoa em potência.

A análise mais detida dessas ideias revela que a busca do telos nada mais significa do que o atendimento das prioridades básicas que permitem a sobrevivência, ou, de outro modo, o atendimento de necessidades primordiais: expressões que, em si, geraram muita controvérsia, não havendo acordo sobre o que se pode considerar essencial. Assim, há quem se baste com a ideia de sobrevivência (persevare in esso suo); outros (Aristóteles, v.g) incluem o cultivo interessado do intelecto humano, ou o conhecimento de Deus (São Tomás de Aquino), ou a associação dos indivíduos tomando por parâmetro a sobrevivência $(\text { Hobbes e Hume })^{540}$.

\footnotetext{
${ }^{539}$ Ibid., p. 206.

540 Ibid., pp. 207-208. Escreve Hart: "Este simples pensamento tem de facto muito a ver com as características, quer do direito, quer da moral, e pode ser destrinçado dos pontos mais discutíveis da visão geral teleológica, em que o fim ou o bem para o homem surge como modo específico de vida, acerca do qual os homens podem, de facto, estar em profundo desacordo. Além disso, podemos, ao referirmo-nos à sobrevivência, pôr de lado, como demasiado metafísica para os espíritos modernos, a noção de que tal é algo
} 
Em resumo, mesmo com a invocação de uma concepção teleológica da vida humana, a consideração do feto como pessoa em potência, merecedor de respeito em prol da realização dos escopos e fins últimos, encontraria num véu nebuloso de indefinições um limite sério, verdadeiro obstáculo à dogmatização que comumente se propõe.

Além disso, tal argumento é repetido incessantemente, sem que se demore um pouco nas premissas em que se assenta. Necessário se faz, portanto, investigar mais detidamente os fundamentos da proteção de uma pessoa potencial.

O argumento da potência é, pois, de expectativa, e tem o foco na extremidade que se projeta o feto ou embrião: uma pessoa plena. Contudo, adverte Peter Singer que

não existe uma regra que afirme que um $X$ potencial tenha o mesmo valor de um $\mathrm{X}$, ou que tenha todos os direitos de um $\mathrm{X}$. Há muitos exemplos que mostram exatamente o contrário. Arrancar uma bolota de carvalho em germinação não é o mesmo que derrubar um venerável carvalho. Colocar um frango vivo dentro de uma panela com água fervente seria muito pior do que fazer o mesmo com um ovo (...) Na falta de qualquer inferência geral de "A é um X potencial" a "A tem os direitos de um X" não devemos admitir que uma pessoa em potencial possa ter os mesmos direitos de uma pessoa, a menos que nos seja fornecida alguma razão específica de por que deve ser assim nesse caso específico. Mas que razão poderia ser essa? ${ }^{541}$.

Há quem se apegue ao valor sagrado da vida que, como vimos, pode ter inúmeras razões de ser. A sacralidade não apresenta, necessariamente, um sentido religioso. Ao ser interrompida a gestação, estaríamos privando o futuro de uma pessoa. Porém, esse argumento, se levado às últimas consequências, também ensejaria a condenação de métodos contraceptivos, que também impedem que alguém nasça.

fixado antecipadamente, que os homens necessariamente desejam, porque é o seu objectivo ou fim apropriado. Em vez disso, podemos sustentar que é um facto meramente contingente, que podia ser de outro modo, os homens em geral ao designar a sobrevivência como um objectivo ou fim humano, do que os homens efectivamente desejarem-na. Contudo, mesmo se pensarmos nela deste modo próprio do senso comum, a sobrevivência tem ainda um estatuto especial em relação à conduta humana e no nosso pensamento acerca dela, o qual se acha em paralelo com a proeminência e a necessidade que lhe são atribuídas nas formulações ortodoxas do Direito Natural. Porque não se trata apenas de uma maioria esmagadora de homens desejar efectivamente viver, mesmo à custa de miséria hedionda, mas de isso reflectir em todas as estruturas do nosso pensamento e linguagem, em termos das quais descrevemos o mundo e nos descrevemos uns aos outros. Não podemos subtrair o desejo geral de viver e deixar intactos conceitos como perigo e segurança, dano e benefício, necessidade e função, doença e cura; porque estes são modos de simultaneamente descrever e apreciar as coisas, por referência à contribuição que dão para a sobrevivência, a qual é aceite como um objectivo".

${ }^{541}$ SINGER, Peter. Ética prática. São Paulo: Martins Fontes, 2002, p. 163. 
Um dos problemas do argumento, como se vê, é o risco de retrocedermos nas considerações relativas às potencialidades. Melhor explicando: tudo pode ser potencial para que um feto se torne uma pessoa, o que pode tornar imprestável ou retirar a força que se quer conceder à potencialidade.

Além dessa objeção, destacada por Peter Singer em algumas de suas obras, o autor dá ênfase a outra crítica que pode ser endereçada ao argumento da potencialidade de um embrião ou de um feto, concernente ao fato de que a potência desses seres não significa que possamos realmente causar dano no mesmo sentido que podemos causar a um ser que "quer", "tem desejos" e "possa sofrer". Ademais, o fato de um determinado embrião poder se tornar uma pessoa não significa que ele seja capaz de sofrer algum dano ${ }^{542}$.

O sentido que Singer atribui ao "dano" pode ser compreendido em termos comparativos, tomando como paradigma as pessoas, conforme o significado atribuído ao conceito que apontamos acima. Assim, se o embrião e o feto não se enquadram no conceito de pessoa, com todos os atributos que lhe são inerentes, não são passíveis de dano. Enfim, para compreensão dessa ideia, é preciso deixar assentado que são entidades distintas.

E, com tal ideia de potencialidade, equiparam-se fatores absolutamente distintos: a pessoa por vir ainda nem existe, porém o embrião e o feto a ela são equiparados. Há aí uma abordagem prospectiva, em que se atribui um valor comparativo da pessoa que será. Enfim, com os argumentos da potencialidade, o que se quer deixar assentado é que o zigoto e o feto possuem direito à vida, pelo simples fato de a pessoa em que se desenvolverão terem assegurado o direito à vida ${ }^{543}$.

Convém destacar que aquilo que poderá ser ainda não é. Não há como equiparar, valorativamente, duas realidades tão distintas. O fato de ser possível que alguma coisa se desenvolva em algo não pode fazer com que dois objetos ou seres sejam tratados,

${ }^{542}$ SINGER, Peter. Rethinking life and death: the collapse of our traditional ethics. New York: St. Martin's Griffin, 1996, pp. 97-100. Destacando o fato dos embriões conservados em laboratório, escreve Singer, para reforçar que a potencialidade não é garantia de tornar-se uma pessoa: "o fato de o embrião ter certo potencial não significa que nós podemos realmente causar-lhe dano, no sentido que podemos causar a um ser que tem necessidades e desejos ou possa sofrer. O que significa se o embrião não realizar seu potencial é realmente que um ser humano particular não virá ao mundo. Mas cada decisão em procriar ou não é uma decisão sobre se um ser humano determinado virá ou não ao mundo - mesmo que a natureza específica daquele ser possa ser indeterminada ao tempo em que a decisão é feita" (tradução nossa). No original: "the fact that the embryo has a certain potential does not mean that we can really harm it, in the sense in which we can harm a being who has wants and desires or can suffer. What it means if the embryo does not realise its potential is really that a particular human being will not come into the world. But every decision to procreate or not is a decision about whether a particular being will or won't come into world even though the precise nature of that being may be undetermined at the time the decision is made".

${ }^{543}$ BOONIN, David. A defense of abortion. Cambridge: Cambridge University Press, 2005, p. 46. 
necessariamente, de modo equivalente. Poderá sê-lo, sabendo-se, no entanto, das diferenças entre aquilo que se compara com seu desenvolvimento potencial.

Há quem distinga, assim, as ideias referentes a um potencial preservador de identidade e um potencial de não identidade. $\mathrm{O}$ primeiro pode ser expresso no sentido de que " $\mathrm{X}$ tem o potencial para tornar-se $\mathrm{Y}$ somente se $\mathrm{X}$ e $\mathrm{Y}$ fossem idênticos - ou seja, somente se $\mathrm{X}$ e $\mathrm{Y}$ fossem uma e a mesma entidade individual" ${ }^{, 544}$. No segundo caso,

quando X possui o potencial de não identidade para tornar-se $\mathrm{Y}, \mathrm{X}$ originará $\mathrm{Y}$, ou contribuirá causalmente para a produção de $\mathrm{Y}$, sempre que sua matéria constitutiva se transformar de tal maneira que, embora o próprio $\mathrm{X}$ deixe de existir, um novo e diferente indivíduo, Y, será formado a partir dessa mesma matéria $^{545}$.

Ontologicamente, a diferença persistirá.

Sem dúvida, a linguagem da potencialidade é, em si mesma, enganadora. Muitas vezes é considerada com o significado de que um X, que é um Y em potencial, já possui, de algum modo misterioso, o ser e o significado de Y. Mas, se $\mathrm{X}$ é um Y em potencial, deduz-se claramente que os fetos não são pessoas. Como consequiência, $\mathrm{X}$ não tem os mesmos direitos de $\mathrm{Y}$, tem apenas potencialmente os direitos de $\mathrm{Y}$. Se os fetos são apenas pessoas em potencial, eles não têm os direitos das pessoas ${ }^{546}$.

David Boonin destaca que um dos grandes defensores da ideia da potencialidade foi Burleigh T. Wilkins; ainda assim, ele entende que o argumento da potencialidade não se mantém a análises mais acuradas ${ }^{547}$.

Portanto, não haveria que se tratar o feto ou o embrião como se pessoa fossem, antecipando uma realidade apenas possível. Além disso, há inúmeros desdobramentos que podem ser analisados no estudo do argumento da potencialidade, que começaram a ganhar corpo na década de $1970^{548}$.

${ }^{544}$ MACMAHAN, Jeff. A ética no ato de matar, Porto Alegre: Artmed, 2011, p. 319. Exemplifica o autor com a ideia de que o príncipe Charles tem o potencial para se tornar rei da Inglaterra.

${ }^{545}$ Ibid., pp. 319-320. No exemplo do autor, o espermatozoide e o óvulo juntos têm o potencial de formar um zigoto.

${ }^{546}$ ENGELHARDT Jr., H. Tristam. Fundamentos da Bioética. São Paulo: Loyola, 2004, p. 179.

${ }^{547}$ BOONIN, David. A defense of abortion. Cambridge: Cambridge University Press, 2005, pp. 45-49.

${ }^{548}$ TOOLEY, Michael; WOLF-DEVINE, Celia; DEVINE, Philip E; JAGGAR, Alison M. Abortion: three perspectives. New York: Oxford University Press, 2009, p. 37. Destaca o autor: "a importância desta questão 
Outro argumento que confere vigor à potencialidade de fetos e embriões atrela-se à capacidade potencial para pensar e para se tornar autoconsciente, como garantidores do direito à vida. Para explanação do assunto, faz-se analogia com adultos em coma. No caso de estados comatosos temporários, é fato que há uma potencialidade de que o indivíduo retome as capacidades de pensamento e de consciência. Noutros casos, em que o coma é decorrente de sério comprometimento do cérebro e, na verdade, já se verifica a morte cerebral, não há mais qualquer possibilidade de retomada das capacidades racionais. Com isso, faz-se uma analogia com fetos e embriões, que estariam muito próximos do primeiro exemplo: eles se desenvolverão em pessoas capazes de pensamento, autoconscientes. Isto lhes confere, pois, o direito de ter a vida biológica protegida. Michael Tooley, no entanto, rebate esse argumento de defesa da potencialidade ${ }^{549}$.

Para começar, destaca-se que a potencialidade pode ser vista de inúmeras formas, como a potencialidade ativa e a potencialidade passiva. No que concerne à potencialidade ativa, diz-se de todos os fatores causais positivos que estão presentes num determinado corpo "X" para que adquira uma propriedade "P". A potencialidade passiva, por sua vez, liga-se à necessidade de que seja feito algo para que " $\mathrm{X}$ " adquira uma dada propriedade "P" $\mathrm{P}$ "50.

Vale dizer, nesse sentido, que Michael Tooley rejeita a mera menção tanto à potencialidade ativa (que possuiriam fetos, embriões e pessoas em coma temporário) como à potencialidade passiva de aquisição da capacidade de pensar e de autoconsciência como relevantes na concessão e proteção do direito à vida. Para o autor, o que mantém, filosoficamente, o direito à vida daqueles que estão temporariamente inconscientes é a capacidade de relembrar as próprias memórias, e retomar a identidade pessoal, ou seja, a potencialidade de existência contínua.

Outro argumento pró-potencialidade diz respeito ao fato de algo poder se transformar em alguma coisa que possui um valor intrínseco: se o feto se transformará num humano adulto, é de se proteger seu direito à vida. Michael Tooley rejeita esse argumento,

sobre potencialidades para o assunto atinente ao status moral do aborto não era realmente percebida até por volta do início dos anos 70. Portanto, alguém não encontra muitos argumentos tratando do assunto nos escritos dos grandes teóricos de Ética do passado. Desde o começo dos anos 70, entretanto, uma variedade de argumentos, que eu devo considerar, foi oferecida de ambos os lados do assunto" (tradução nossa). No original: "the importance of this question about potentialities for the issue of the moral status of abortion was not really noticed until around the early 1970s. Accordingly, one does not find many arguments bearing upon this issue in the writings of the great ethical theorists of the past. Since the early 1970s, however, a variety of arguments, which I shall consider, have been offered on both sides of this issue".

${ }^{549}$ Ibid., pp. 37-38.

${ }^{550}$ Ibid., pp. 38. 
fazendo uma distinção entre algo ter direito à vida e ter valor em "sentido axiológico" 551 . É necessário salientar que algumas posições de Tooley são por demais extremadas; sua obra, porém, tem uma linha de coerência.

Para rebater a ideia de potencialidade como atributo para conferir um direito à vida, inúmeros autores elaboraram uma série de outros argumentos. Mary Anne Warren, autora do artigo "On the Moral and Legal Status of Abortion", combate o ideia da potencialidade dizendo que, a vingar essa tese, cada célula do corpo teria direito à vida, pois pode originar um adulto através da transferência nuclear (processo de clonagem), o que é contraargumentado através das ideias de potencialidade ativa e passiva ${ }^{552}$.

Em outra linha de argumentos, pode ser citada a da potencialidade "quase-ativa" (almost active potenciality), que compara situações em que um espermatozoide direcionase com uma potencialidade ativa para fertilizar um óvulo dentro do útero à retirada de um óvulo já fertilizado. Fora do útero, não há uma potencialidade ativa que se atualize (daí, potencialidade quase-ativa). Seria pior destruir um espermatozoide, nesse exemplo, a um óvulo fecundado que não será implantado num útero ${ }^{553}$.

Há quem diferencie, ainda, uma potencialidade restrita de uma potencialidade irrestrita.

De acordo com a primeira ideia (potencialidade restrita), se a algo que possui determinada propriedade "P" tem resguardado o direito à vida, qualquer coisa que no futuro possa adquirir esta propriedade "P" no curso de seu desenvolvimento terá, também, o direito à vida. De outro lado, se considerada tal afirmação como correta, também deverá sê-lo o argumento de uma potencialidade irrestrita, de acordo com a qual se algo com uma propriedade "P" é merecedor de ter sua vida protegida, qualquer ação que impeça a aquisição dessa propriedade "P" por um dado organismo deve ser considerada errada. Entretanto, a crítica realizada a esse argumento é a de que ele pode ocorrer num curso ilimitado, pois muitas coisas podem ser causa para que, por exemplo, ocorra a fecundação

\footnotetext{
${ }^{551}$ Ibid., pp. 40-41. Escreve o polêmico autor, em termos utilitários: "num mundo já superpovoado, pessoas a mais não são, em geral, entidades de valor no sentido axiológico, desde que, a despeito de pessoas com habilidades especiais, que podem beneficiar bastante a sociedade, adicionar mais pessoas ao mundo o torna um lugar pior, em vez de um lugar melhor. Mas se as pessoas são acrescentadas ao mundo, elas certamente têm um sério direito à vida" (tradução nossa). No original: "in an already overpopulated world, extra people are not in general valuable entities in the axiological sense, since, aside from people who, because of special abilities, can beneficit society greatly, adding extra people to the world makes the world a worse place, rather than a better one. But if people are added to a such world, they certainly have a serious right to life". Vale destacar que alguns exemplos trazidos pelo autor são imaginados em termos praticamente irreais, mas sua pretensão, com isso, é ilustrar, didaticamente, a implausibilidade daquilo que refuta, o que confere efeito didático.

${ }_{552}$ Ibid., p. 42.

${ }^{553}$ Ibid., pp. $42-43$.
} 
de um óvulo, como o próprio fato de duas pessoas se conhecerem. Quem rejeita a arguição de uma potencialidade irrestrita, deve apontar no curso de eventos que sucedem durante a fertilização um ponto em que alguma mudança substancial ocorre, o que, para os críticos, seria uma escolha arbitrária (arbitrary line objection) ${ }^{554}$.

Ainda na esteira dos argumentos que refutam a solidez da potencialidade, cita-se o princípio da simetria moral. Argue-se que impedir que um processo em curso gere alguma coisa ou chegue a seu termo tem o mesmo valor de "quem tem capacidade de iniciá-lo, sequer o faça". Cuida-se da equivalência, nesses termos, entre as ações e as omissões, que causam muita discussão entre os filósofos. Outro argumento parelho a este seria o da comparação moral que, entretanto, não cai nas conclusões de que matar e deixar morrer são em si equivalentes ${ }^{555}$.

Enfim, consideramos, com base em outros autores, que o fato de uma pessoa ter direito à vida não enseja, necessariamente, que o feto ou o embrião possam ser considerados pessoas em potência, numa análise prospectiva que não se sustenta a uma reflexão mais detida ${ }^{556}$.

Entendemos, pois, que a pessoa - e não sob as vestes do argumento da potencialidade - deve ser considerada um critério para decisão relativa à interrupção da gravidez, e não o apego à sacralidade da vida que, a despeito da importância como substrato para o sujeito moral, enseja um absolutismo que conduz a uma só solução correta: não interromper a gravidez em hipótese alguma.

\subsection{A Pessoa moral}

Muitas foram as concepções de pessoa analisadas até o momento; não há um só conceito de pessoa. Isso não significa, entretanto, um abismo absoluto entre todos os

\footnotetext{
${ }^{554}$ Ibid., pp. 43-46.

${ }^{555}$ Ibid., pp. 46-49.

${ }^{556}$ MACMAHAN, Jeff. A ética no ato de matar, Porto Alegre: Artmed, 2011, p. 333. Leciona o autor: "a questão relevante levantada pelo potencial de um indivíduo diz respeito à medida em que seria importante, tendo em vista o bem do próprio indivíduo, que ele viesse a realizar esse potencial - ou seja, que ele viesse a se tornar aquilo que é possível que ele se torne ou que ele viesse a obter aquilo que é possível que ele obtenha. No caso do aborto, portanto, a importância moral do potencial do feto é inteiramente capturada pela abordagem do interesse temporalizado. Seja qual for a razão para assegurarmos a realização do potencial do feto para tornar-se uma pessoa, ela estaria subsumida à razão que temos para respeitar o seu interesse temporalizado em continuar vivendo. $\mathrm{O}$ bem que há em tornar-se ou em ser uma pessoa é uma dimensão do bem que o futuro desse indivíduo poderia conter e em relação a cuja posse ele tem um interesse temporalizado presente (...) no entanto, que o seu interesse temporalizado presente em possuir os bens de seu próprio futuro é relativamente fraco, dada a quase ausência de conexões psicológicas entre ele agora, como um feto, e ele próprio posteriormente, como uma pessoa. O que isso significa é que é relativamente pouco importante, visando ao bem do próprio feto agora, sabermos se o seu potencial será realizado ou não".
} 
entendimentos aqui destacados, de maneira que alguns, ressalvada uma ou outra peculiaridade, poderiam ser englobados numa mesma corrente quanto ao sentido que se quer atribuir ao termo em questão.

Vale dizer, no entanto, que muitas das discussões existentes na utilização da palavra pessoa devem-se ao fato de os contendores estarem se referindo a sentidos diferentes, todos possíveis, mas que não se igualam.

Este item em questão tem um escopo de síntese, de esclarecimento e aprofundamento da concepção que aqui se adota. Em primeiro lugar, síntese não quer significar uma conclusão fechada a questionamentos ou uma solução definitiva sobre o assunto: não é esta a pretensão. Assim, o objetivo é concatenar as premissas estabelecidas para a proposta que realizamos neste estudo.

De início, salientamos que critério é tomado com o sentido de ponto de partida, que não é o único (senão seria um dogma incontrastável). Ele não exaure as inúmeras faces presentes nas discussões sobre o aborto. Desta maneira, a pessoa como critério para a decisão, nos casos de aborto provocado, significa um dos elementos que também deve ser levado em conta, para além dos inúmeros outros. Vale relembrar que predomina, neste estudo, o enfoque zetético-jurídico.

Além disso, referimo-nos à pessoal moral, que é um dos inúmeros conceitos existentes nas discussões dos diversos ramos do saber. Podemos sintetizá-los em três grupos, basicamente: pessoa biológica, pessoal legal, pessoa moral, como faz Eugene Scholossberger.

Pauta-se o autor na distinção entre esses tipos de pessoa. A pessoa biológica equivaleria àquilo que assentamos no capítulo anterior, relacionado ao pertencimento à espécie Homo sapiens, ao qual dedicamos um tópico de análise neste capítulo. Pessoa biológica é, nesse sentido, o mesmo que ser humano, que se desenvolve num continuum biológico, caracterizado por uma carga genética específica, por uma composição física com funções características. Este é o entendimento de muitos dos autores que reafirmam a dignidade intrínseca à espécie. Não podemos desconsiderar que esta é uma das abordagens possíveis do termo, e nada impede que se convencione apontar o organismo como pessoa, mas o só fato de ser possível não indica que seja suficiente para muitas das discussões da seara moral, ensejando um absolutismo axiológico.

Pessoa legal, por sua vez, refere-se ao que determinado ordenamento considera como sujeito em uma ordem de relações jurídicas. Nesse caso, nem sempre será um humano, podendo tal atributo recair sobre outros animais, corporações e outras entidades 
sem vida em sentido estritamente biológico. A variação aqui é ditada por uma escolha do legislador, que seleciona alguns entes para atribuir obrigações, conceder direitos, participar de uma vida jurídica.

Entretanto, não são estes tipos de pessoa que merecem destaque na obra de Scholossberger, até porque já discorremos sobre o assunto. Resta-nos aprofundar o que aqui se entende por pessoa moral.

Primeiramente, pessoa é um termo que significa um status, uma situação (status term), daí ser possível dizer que cada um dos conceitos de pessoa que são desenvolvidos indica certa condição a que remete (biológica, legal ou moral) ${ }^{557}$. Essa qualidade de status liga-se a ao que Scholossberger denomina de termos intencionais (intentional term). Melhor explicado: as palavras são signos que se referem a algo, possuem uma significação. O sentido que é dado é convencional, advém de acordos sociais, de costumes. Os termos intencionais, desta maneira, podem ser assim considerados pelo status ou pela função $^{558}$. Pessoa é um termo intencional relacionado a um status.

Em segundo lugar, pessoa é um termo composicional (compositional term) que tem um sentido independente e não parasítico em relação a outras expressões ou termos. Em outras palavras, podemos contar as pessoas, como contamos as árvores e os rios ${ }^{559}$.

Isto posto, o que é, e o que faz com que alguém seja enquadrado como uma pessoa moral (ou agente moral)? Muito do que será dito neste tópico tem amparo em alguns dos autores já estudados.

Para Eugene Scholossberger, crucial para a compreensão da personalidade moral pois a ela liga-se intrinsecamente - é a ideia de visão de mundo (worldview), que pode ser expressa na interação de alguém com o mundo. Assim, diz o autor, as pessoas morais são capazes de julgar, avaliar e compreender-se. Suas atitudes, crenças, disposições, emoções, expectativas, objetivos, desejos formam uma moldura de significados. Enfim, corresponde

\footnotetext{
${ }^{557}$ SCHLOSSBERBER, Eugene. Moral responsibility and persons. Philadelphia: Temple University Press, 1992, p.23.

${ }^{558}$ Ibid., pp. 25-26. Por exemplo, a palavra “arma”. Não há como dizer o que é uma arma em si. A definição do que seja arma vai depender da função que se atribua a um objeto, propriamente ou impropriamente, num determinado contexto. Assim, a faca poderá ser considerada arma conforme seja utilizada para ferir ou matar alguém. "Arma" é referencial a um outro objeto, a faca. A gentileza, a bondade, a avareza são qualidades que indicam também um atributo que se refere a algum ser. Assim como pessoa, sendo termos que indicam status.

559 Ibid. Ao contrário das armas por exemplo. De fato, só podemos contar quantas armas há numa determinada sala, após convencionarmos o que entendemos por arma, relacionando aos objetos que assim identificarmos no lugar, como o número de facas. Nesse sentido, não podemos dizer que pessoa seria parasítico ao homem considerado em sentido biológico, com a mesma consideração que contamos armas em facas, revólveres, machados etc. Para o autor, pessoa já seria, em si, um termo primário.
} 
à maneira de compreender, preocupar-se e interagir com o mundo à volta, e muito do que fazemos e sentimos expressa nossa peculiar visão de mundo ${ }^{560}$.

Entre as escolhas que fazemos, podemos distinguir aquelas que são proclamativas de outras não proclamativas. As primeiras, ao contrário das segundas, afirmam um valor que consideramos exemplar. Muitas de nossas escolhas são morais nesse sentido. Além disso, pode-se dizer que a visão de mundo de alguém, como sujeito moral, expressa-se pelas emoções, que alguns autores consideram uma forma de julgamento. Nossos sentimentos caracterizam nossa situação e as emoções constituem parte de nossa personalidade ${ }^{561}$

Em resumo, a pessoa moral é conceito composicional que indica um atributo concernente à síntese constitutiva de uma visão de mundo, que envolve julgamento, avaliação, atitudes, percepções, crenças, valores e assim por diante. São "organismos" sobre os quais podemos contar uma história, ou melhor, representam uma coleção de estágios temporais (temporal stages), sobre os quais certo tipo de história psicológica pode ser contado ${ }^{562}$. Por consequência, somente as pessoas morais podem ter interesses, e a personalidade moral é correlacionada à circunstância de ter direitos. Apresentar uma visão de mundo, uma visão moral, é a base para a atribuição de direitos ${ }^{563}$.

Uma observação vem a calhar: Eugene Scholossberger não conclui, com isso, que somente os humanos seriam pessoas. Assim, é válido dizer, no mesmo sentido de Peter Singer, que qualquer ente que possua essas qualidades poderá ser considerado uma pessoa em sentido moral. Aliás, a visão de Scholossberger não destoa muito daquelas que analisamos atinentes à enumeração de determinadas características, como Joseph Fletcher, Peter Singer, Michael Tooley, mas é descrita de modo peculiar sobre como possuir uma visão de mundo (worldview).

O feto e o embrião, contudo, não seriam agentes morais - e isso, por si só, não poderia representar tanto transtorno em relação à prática do aborto. Mas esse raciocínio deve se aplicar para as situações limítrofes, como nos casos de bebês, crianças e todos os outros que não têm, ou nunca terão, uma moldura como a que esboçamos acerca dos desejos, julgamentos, avaliações etc.

\footnotetext{
${ }^{560}$ Ibid., p. 33-34.

${ }^{561}$ Ibid., pp. 35-43.

${ }^{562}$ Ibid., p. 60-61. A discussão pode ser aprofundada em termos de se perquirir o que faz com que alguém tenha a mesma identidade e seja a mesma pessoa, e não outra. Cuida-se de um dos mais controversos debates sobre a personalidade.

${ }^{563}$ Ibid., p. 73.
} 
Exsurge a noção de pessoas morais parciais, que não representa uma situação de tudo ou nada, mas a aceitação de que existem seres humanos que, por não encerrarem uma visão de mundo no sentido acima analisado, teriam apenas alguns direitos e obrigações - o que é causa de ferrenha polêmica. Afinal, o que torna alguém reconhecidamente como um sujeito moral completo e não ainda parcial?

Eugene Scholossberger explica que o desenvolvimento da personalidade moral é um continuum, algo que se dá de modo paulatino. Finaliza reconhecendo o próprio limite teórico: não é possível criar uma tabela, o que demandaria uma teoria da natureza humana $^{564}$. A própria lei sequer atreve-se a elaborar semelhante esquadrejamento, limitando-se a estipular uma idade para o voto, outra para a maioridade, outra para o exercício de determinados cargos. Isto não se dá por critérios equivalentes a uma realidade, mas sim por razões práticas, ficção ${ }^{565}$.

Santiago Nino, que também aborda a questão da pessoalidade moral, aduz que a cidadania moral não é uma questão de teoria biológica, ou algum tipo de teoria descritiva, mas sim de teoria política, teoria moral em sentido amplo. Escreve, ademais, que a personalidade moral é conceito que se relaciona não ao fato de ser titular de direitos fundamentais, mas ao fato de possuir as condições para exercê-los ${ }^{566}$.

Como decorrência lógica, reconhecer que existem limites fáticos e normativos para a condição de pessoa moral enseja admitir um permanente alargamento dessa condição, mediante a superação dos obstáculos de fato para gozar dos direitos em questão. Para o autor, essa visão heterodoxa da personalidade moral tem consequências relevantes para as questões relacionadas ao aborto, a eutanásia, os direitos dos animais etc ${ }^{567}$.

Entre as várias concepções apresentadas, muitas são, sem dúvida, noções de pessoa moral. Assim o faz Joseph Fletcher, ao tentar estabelecer uma série de atributos - visão que influenciaria algumas ideias de Peter Singer -, e Michael Tooley. Destarte, podemos dizer que são definições que partem da estruturação de qualidades ou condições para que a um determinado organismo possa ser conferido esse status.

Complementando o raciocínio, pode-se dizer que o agente moral existe após o nascimento, o que vai ao encontro do que preconiza a abordagem psicológica. Mas, a depender do grau de conectividade psicológica que precede o nascimento e está presente

\footnotetext{
${ }^{564}$ Ibid., pp. 73-77.

${ }^{565}$ Ibid., p. 78.

566 NINO, Carlos Santiago. Ética y derechos humanos: un ensayo de fundamentación. Buenos Aires: Editorial Ástrea, 2007, pp. 45-46.

${ }^{567}$ Ibid., p.47.
} 
no feto, e no caso em que uma pessoa sofra algum mal que diminua essa conectividade psicológica, fala-se em pré-pessoa e pós-pessoa, conforme estudo de Jeff MacMahan ${ }^{568}$.

Isto posto, uma noção de pessoalidade moral se extrai, em certa medida, de uma perspectiva subjetiva, de uma análise que se pauta pelos interesses das pessoas que são afetadas por nossas ações. Norman M. Ford destaca que sob esse ângulo, e de forma crítica, a pessoa humana não pode existir em abstrato, sem um nome, um gênero, idade, uma vida influenciada por relações e experiências. A identidade é, assim, inseparável das experiências, dos relacionamentos, compartilhamentos, comunicação, diálogo - mesmo que marcados por limitações e ambiguidades. Assim, viver isoladamente empobrece a pessoa, que não é completa no isolamento ${ }^{569}$.

Considerado o encaminhamento deste estudo, pessoa é aqui tomada num sentido nominalista, como o descrito por Simon J. Evnine, em contraposição às concepções realistas, que condicionam a pessoalidade ao pertencimento à espécie Homo sapiens ${ }^{570}$. Assim, abonamos o pensamento de Singer acima destacado, que tem inegável influência de Fletcher, e que complementa o pensamento desenvolvido neste item, em que a racionalidade, a autoconsciência e outros indicadores são de extrema relevância para indicação do que se compreende por um sujeito moral.

Enfim, não basta a consideração do substrato biológico para análise das controvérsias bioéticas. É necessário tomar como parâmetro a pessoa moral. Ou seja,

a animalidade da natureza humana não nos pode fazer esquecer o fato, não menos evidente, de que o homem é um ser essencialmente moral, ou seja, que todo o seu comportamento consciente e racional é sempre sujeito a um juízo sobre o bem e mal (...) Para definir a especificidade ontológica do homem, sobre a qual fundar a sua dignidade no mundo, a antropologia filosófica hodierna vai aos poucos estabelecendo um largo consenso sobre algumas características próprias do homem, a saber, a liberdade como fonte da vida ética, a autoconsciência, a sociabilidade a historicidade e a unicidade existencial do ser humano 571 .

\footnotetext{
${ }^{568}$ MACMAHAN, Jeff. A ética no ato de matar, Porto Alegre: Artmed, 2011, pp.57-59.

${ }^{569}$ FORD; Norman M. The prenatal person: ethics from conception to birth. Reino Unido: Blackell, 2002, pp.10-12.

${ }^{570}$ EVNINE, Simon J. Epistemic dimensions of personhood. Nova York: Oxford University Press, 2008, p. 4-5.

${ }^{571}$ COMPARATO, Fábio Konder. Fundamento dos direitos humanos. Revista do Instituto de Estudos Avançados da Universidade de São Paulo, p. 12. Disponível em: http://www.iea.usp.br/textos/comparatodireitoshumanos.pdfv
} 
Finalizamos nosso estudo com a análise do documentário que aborda situações verídicas em que a pessoa moral vem a lume no momento da tomada da decisão.

\subsection{Análise do documentário $O$ aborto dos outros}

O documentário O aborto dos outros, dirigido por Carla Gallo, aborda com muita acuidade casos reais de interrupção da gravidez, dentre os quais alguns realizados por médicos por consubstanciarem hipóteses de aborto legal. Entre os casos apresentados, há também aqueles que chegaram ao conhecimento médico ou de autoridades após complicações decorrentes da tentativa de abortamento clandestina.

O aborto como problema de saúde pública ${ }^{572}$ predomina como tônica na película de Carla Gallo, pois, na maioria dos casos de abortamento ilegal, podemos verificar os reflexos na seara médica. Além disso, a abordagem delineia questões de ordem social, econômica, psicológica. Não há um problema isolado, mas sim um dilema multifacetário o que corrobora a necessidade de uma abordagem interdisciplinar e dialógica.

Como sintetiza a diretora, $O$ aborto dos outros é um filme sobre maternidade, afetividade, intolerância e solidão. A narrativa percorre situações de abortos realizados em hospitais públicos - previstos em lei ou autorizados judicialmente - situações de abortos clandestinos. O filme mostra os efeitos perversos da criminalização para mulheres e aponta a necessidade de revisão da legislação brasileira ${ }^{573}$.

É importante estabelecer, desde já, que os assuntos abarcados em $O$ aborto dos outros podem ser expandidos, especialmente se contextualizados à questão dos direitos reprodutivos, sobre os quais tratamos no capítulo segundo. De fato, está em cena a outra face do direito à maternidade, ou seja, o direito de não ser mãe, de não iniciar uma relação simbiótica de mútuas trocas entre o feto e a gestante por escolha consciente que envolve uma superação da própria condição e o controle dos rumos da vida. Entre procriar e não procriar há um ser racional, que aceita ou não o papel social atinente à maternidade, que é comunicacional.

\footnotetext{
572 TOOLEY, Michael; WOLF-DEVINE, Célia; DEVINE, Philip E.; JAGGAR, Alison M. Abortion: three perspectives. New York: Oxford, 2009, p. 136. Para Alison M. Jaggar, o aborto deve ser reconhecido como um serviço essencial de cuidado à saúde, acessível, integrado a outros serviços de saúde, integrando educação reprodutiva, serviços de planejamento familiar, aconselhamento pré e pós-aborto.

${ }^{573}$ Disponível em: 〈http://www.oabortodosoutros.com.br/index_pt.html〉, Acesso em 08 de agosto de 2011. O endereço eletrônico disponibiliza inúmeros textos, escritos por vários autores, sobre a temática abordada no documentário, o que corrobora a perspectiva de integração da teoria à imagem como forma de expansão e aprofundamento do conhecimento humano, que integra perspectivas racionais e afetivas, de modo complementar.
} 
Nesse sentido, segundo destaca Bárbara Katz Rothman, um bebê não entra no mundo do nada. Ele já entra em uma relação, construída ao longo de nove meses, um relacionamento que é físico, social e emocional ${ }^{574}$.

Tudo isso aparece em contraste com a emergência do feto à condição de paciente, o que pode acentuar o teor e os ânimos dos debates: a visualização do feto, através do ultrassom, cria uma atmosfera de encantamento.

O documentário em questão permite que se apreenda não somente a abstração teórica destacada no capítulo segundo, mas a contextualização imagética de situações verídicas, pautadas por situações em que a emoção e a razão imiscuem-se numa totalidade humana indissociável.

Assim, ao contrário do documentário $O$ grito silencioso, não se discute, aqui, o status da vida fetal. A ótica é outra, e o enfoque é o das motivações que levaram a mulher a interromper a gestação.

O primeiro caso apresentado, de uma adolescente chamada Maria, que foi violentada sexualmente, inicia-se com um questionário realizado pela Dra. Daniela, psicóloga do hospital em que será realizado o procedimento abortivo. O interrogatório abrange desde a reconstrução do histórico da situação em que ocorreu o estupro até questionamentos atinentes às sensações e sentimentos da garota violentada.

As opções diante da gravidez, de acordo com a psicóloga que acompanha o caso, são três: a) levar a gestação adiante; b) “doar” a criança após o nascimento; c) aborto legal. Dentre as possibilidades, sopesadas as consequências de sua escolha, Maria decide interromper a gestação. Ao ser indagada sobre os motivos de sua escolha ${ }^{575}$, diz a garota, transparecendo a violência psicológica: (...) eu já sofri a agressão de ser estuprada. Cada vez que eu olhar para essa criança, como que não vai ser?

A mãe de Maria, que a acompanha em todos os procedimentos prévios e posteriores à interrupção da gestação, revela que regulava a menstruação da filha e não percebeu nada de diferente, talvez pelos outros problemas de saúde de sua mãe (avó de Maria) que a preocupavam. A descoberta deu-se através de uma ultrassonografia: ela achava, no início, que seria apenas um cisto.

\footnotetext{
${ }_{574}^{57}$ ROTHMAN, Barbara Katz. Recreating motherhood. New York: Rutgers, 2000, p.57.

575 ROSADO-NUNES, Maria José. Aborto, maternidade e dignidade da vida das mulheres. In: CAVALCANTE, Alcilene; XAVIER, Dulce (orgs.). Em defesa da vida: aborto e direitos humanos. São Paulo: Católicas pelo Direito de Decidir, 2006, p. 31.
} 
Todo drama apresentado pela mãe intensifica-se com os relatos que se seguem. Afirma que a filha aparenta estar com a mente bloqueada, e ela, como mãe, fica também abalada com tudo. A filha até pediu-lhe uma boneca no dia das crianças.

Maria, pelo que vemos, é só uma menina que mal chegou à adolescência, enfrentando a necessidade de uma decisão tão complexa - nesse caso, albergada pela lei. A mãe, como representante legal, é quem assina a autorização para a interrupção da gravidez (conforme preconiza o artigo 128, inciso II do Código Penal), respeitando, assim, a vontade de Maria.

Para não ocorrer a identificação física de algumas mulheres, como acontece com Maria e sua mãe, a diretora vale-se de planos que ou deixam de mostrar o rosto, enquadrando as outras partes do corpo, ou deixam de filmar frontalmente as pessoas participantes do documentário.

O nervosismo de Maria é patente. Ela, que nunca saía de casa (salvo para ir à padaria, fazer trabalhos na casa de colegas, ir à escola etc), e que nunca havia ficado internada desde que nascera, agora estava ali, ansiosa com a internação, temerosa e inclusive com dificuldade para engolir o medicamento necessário à realização do aborto.

Mas não é só a menina que sofre com a situação. A mãe, que a acompanha, sente os reflexos da gravidez não desejada, e chora. Há, além de tudo, um conflito interno. Diz a mãe: Eu sempre fui contra o aborto, assim, nos casos normais, em que a mulher engravida sabendo que está correndo risco de engravidar, sabe? Nunca imaginei na minha vida passar por uma situação dessas. Nunca. Ainda bem que eu 'tô' tendo apoio de todo mundo (...) porque senão acho que já teria enlouquecido. E continua: Mas acho que nesse caso, só quem sabe é quem 'tá' passando. Não sabe como 'tá' a cabeça, não sabe nada.

A falta ou precariedade de informações parece um grande complicador para quem deseja realizar um aborto legal. É o que se conclui pela informação que lhe foi dada pelo escrivão em uma delegacia de polícia acerca da demora na autorização do aborto que, de acordo com o agente público, somente seria concedido quando não mais fosse possível realizar o procedimento.

Não é o caso de generalizar essa espécie de atendimento. No entanto, a falta de informações mínimas pode tornar-se um real empecilho no exercício de direitos, até mesmo desencorajando a realização de um aborto legal - o que não significa a ausência de um abortamento, que poderá ser realizado de modo clandestino, talvez aumentando as cifras da mortalidade. 
A complexidade da situação cresce quando entram em cena ponderações e crenças religiosas, tornando tudo mais doloroso. Na fala da mãe de Maria, percebe-se que a escolha por um aborto não é fácil: Eu sei que Deus é contra isso, mas ele sabe o motivo de cada um, entendeu?

Posteriormente ao abortamento por estupro, o documentário trata do caso de interrupção da gravidez por anomalia fetal grave. Nesses casos, convém destacar, a presença da anomalia por si só não constitui pressuposto a fundamentar o aborto legal, que se restringe às hipóteses de gravidez resultante de estupro ou risco de vida da gestante (aborto necessário). Entretanto, vezes haverá em que o Poder Judiciário autorizará a interrupção da gravidez, após pedido casuístico submetido à análise do magistrado.

No caso em tela, trata-se de um feto com graves malformações fetais ${ }^{576}$ : doença multicística e acrania. Como explica o médico que acompanha a gestante, cada uma delas, isoladamente, já seria enfermidade congênita letal, não possibilitando a sobrevivência fora do útero. A expectativa de vida do bebê que nasce nessas condições é ínfima.

Os procedimentos para retirada do feto são preparados, e o close-up capta as lágrimas da mulher, que sabe que em pouco tempo os movimentos que sente no ventre irão cessar. Afirma o médico: Do ponto de vista ético, tenho a tranquilidade, tenho a segurança pra saber que eu estou fazendo o melhor para ela.

A mulher que se submete ao aborto pondera que, no início, quando soube que havia problemas na formação do feto, e que ele não resistiria por muito tempo, ainda assim decidiu que levaria a gravidez adiante, para que seguisse o curso natural: Eu queria deixar nascer, sabe, por religião e tudo mais (...).

Destaca-se nessa fala, ainda que de modo não racionalizado, um dos argumentos comumente utilizados por aqueles que defendem a sacralidade da vida humana, especialmente nos casos de enfermidade letal ao feto. De acordo com esse argumento, seria moralmente correto deixar que a vida humana seguisse seu curso, sem que houvesse uma interferência do ser humano no destino da vida fetal. Cuida-se de um dos mais tormentosos debates éticos relacionados ao aborto, que tenta traçar diferenças relevantes entre as consequências de uma ação e de uma omissão ${ }^{577}$.

No entanto, o marido convenceu-lhe de que seria melhor abortar, já que o sofrimento poderia ser bem maior por terem de deixar o bebê no hospital, após um longo

\footnotetext{
${ }^{576}$ Nesse sentido, é interessante o documentário dirigido por Débora Diniz e Eliane Brum, intitulado Uma vida Severina.

${ }^{577}$ BOONIN, David. A defense of abortion. Cambridge: Cambridge University Press, 2003, pp.188-211.
} 
período de espera. Ainda assim, o vazio permanece, transparecendo a sensação de ausência na mulher, que guarda as roupinhas que comprara ou ganhara de outras pessoas. Esse sentimento tem o condão de desencadear processos de projeção-identificação, robustecidos pelo fato de ser um documentário que pretende retratar o real.

Esses processos de projeção-identificação, bem explicados por Edgar Morin, conectam-se às emoções e à magia daquilo que vemos retratado pelo cinema, e que se desenvolvem também na vida cotidiana.

$\mathrm{Na}$ medida em que identificamos as imagens da tela com a vida real, pomos as nossas projeções-identificações referentes à vida real em movimento. Em certa medida vamos lá efetivamente encontrá-las, o que desfaz a originalidade da projeção-identificação cinematográfica, se bem que, na realidade, a revele ${ }^{578}$.

Mesmo no documentário, não deixa de haver uma participação afetiva daquele que assiste à película, principalmente em casos que retratam limites da própria dignidade humana, processos de escolha que bem poderiam estar presentes na vida de qualquer um.

Em outro caso, verificamos a situação de um aborto decorrente de gravidez não desejada, ocorrida em um casamento já todo desestruturado. A mulher, que já tinha um filho, não gostaria de manter uma relação que já estava em ruínas tão-somente em razão de uma gravidez. Conta a entrevistada desse caso: Infelizmente fiquei grávida. Fiquei grávida, aí fiquei desesperada porque para mim, na minha cabeça, não havia possibilidade nenhuma de ter aquele filho. É diferente do primeiro (...). Nota-se que a gravidez, ao contrário da primeira, não foi planejada.

Para acabar com a gestação não desejada, a mulher utilizou um medicamento abortivo. Em consequência da clandestinidade, teve que conviver 40 dias com sangramentos e secreções, além de sofrer as ameaças de denúncia do marido, que pretendia denunciá-la pelo crime.

Observa-se, como em outros casos analisados, o forte apelo religioso subjacente às decisões tomadas. Como destacado pela mulher: Culpa, culpa de ter feito o aborto eu nunca tive, porque eu penso assim comigo: se for pecado, né, Deus há de me perdoar porque a situação em que eu me encontrava não era para ter o filho.

\footnotetext{
${ }^{578}$ MORIN, Edgar. A alma do cinema. In: XAVIER, Ismail (org). A experiência do cinema. Rio de Janeiro: Edições Gerais Graal, Embrafilmes,1983, p. 151.
} 
Em outra situação de gravidez resultante de estupro, a equipe médica do hospital analisa se há algum indício de que o depoimento prestado pela moça que deseja interromper a gravidez seja mentiroso. Assim, toma criteriosamente as declarações prestadas, confrontando-as. Conclui que as afirmações são verdadeiras e realiza o procedimento. No depoimento, essa paciente revela que, no início, estava mais preocupada com a possibilidade de ter contraído alguma doença do que com a de ter engravidado.

O documentário também trata do problema do aborto usado como método de controle populacional. O caso é de uma mulher que realizou cinco abortos, seja pela falha na utilização da "tabelinha", seja pela não utilização de outras formas de evitar a concepção.

Revela que, em todos os casos, recorreu a uma "mãe de anjo", denominação dada a quem auxilia na realização de aborto clandestino. Demonstra pesar pelo fato de ter consumado todos esses abortos, além de acreditar que, pelas condutas praticadas, receberá punição divina.

Por fim, o último caso apresenta a história de uma mulher cujo aborto resultou na sua prisão, após notícia levada às autoridades policiais. Diz a mulher que o aborto mais foi por causa do desespero, já que não tinha como ficar com o bebê. Nesse caso, a interrupção deu-se com a utilização de um medicamento, mas as complicações foram graves, e ela teve de procurar um hospital, ficando algemada enquanto se restabelecia, o que dificultava todos os seus movimentos, inclusive idas ao banheiro - pois os policiais, muitas vezes, não estavam lá para propiciar a locomoção necessária.

A mulher mostra-se um tanto indignada pela incriminação de sua conduta e pelo fato de terem revelado o fato às autoridades: Se não acontece isso dessa denúncia não ia acontecer nada disso (...) uma pessoa que gostava tanto de mim, gostava tanto dos meus filhos poder fazer isso comigo. E olha que ela já fez o aborto. Eu acho que ela não podia ser contra mim.

Ademais, fica clara a ideia acima estruturada de que o aborto é um fato social de conhecimento amplo. Como relata, o próprio delegado disse que não só ela, mas várias mulheres realizam o procedimento.

Porém o depoimento da mulher termina com a conclusão de que, se fosse necessário, realizaria novamente o aborto. Ou seja, teria, de fato, a norma penal incriminadora poder dissuasório para evitar o cometimento desse delito? 
O documentário encerra-se com depoimentos de especialistas do Direito e profissionais da saúde, que opinam acerca do aborto, sobre aspectos médicos, sociais e jurídicos.

Interessa abordar, ainda que brevemente, o pensamento desses profissionais que lidam quase cotidianamente com a questão do abortamento, seja autorizando a consecução de procedimentos, seja realizando-os, ou mesmo aconselhando e esclarecendo gestantes sobre as consequências do aborto e sobre direitos muitas vezes negligenciados.

Dr. Jefferson Drezett, ginecologista, assevera que o número de mulheres que morrem por ano em decorrência de abortamentos inseguros aproxima-se dos 70.000, sendo que $95 \%$ desses abortos são realizados nos países em desenvolvimento ${ }^{579}$. Fala que, inegavelmente, trata-se de um problema de saúde pública mundial, mas ele tem sido muito mais grave, ele tem sido muito mais pesado sobre os ombros das mulheres dos países em desenvolvimento, que, por sua vez, em geral, mantêm leis restritivas e proibitivas com relação ao abortamento.

Em seguida, Dr. José Henrique Torres, juiz de Direito em Campinas, contribui com seu depoimento. Entende que a legalização do aborto não significaria o abandono das discussões sobre a questão, que passaria a merecer outros enfoques que não simplesmente o penal. Como esclarece, estaríamos tirando o Direito Penal do âmbito do enfrentamento deste problema. Ou seja, passaríamos este problema para uma outra área do Estado, para uma outra área de enfrentamento, e aí teríamos que combater o abortamento neste sentido, de ser um problema de saúde pública.

${ }^{579}$ PAPALEO, Celso Cezar. Aborto e contracepção: atualidade e complexidade da questão. Rio de Janeiro: Renovar, 2000, pp. 31-32. As razões talvez sejam históricas: "Pode admitir-se que a legalização do aborto, a despeito do impacto que representa em termos de moral e de costumes, é fato jurídico relevante da segunda metade deste século. Oportuno reconhecer que a franquia abortiva, de caráter progressivo, em difusão, ocorre apenas no século XX, de vez que, até mesmo os países não católicos a repeliam, assim como praticamente todas as nações do Ocidente. Via-se no aborto, além de ato ilegal contra a vida, agravo aos interesses maiores da sociedade e do próprio Estado.

$\mathrm{Na}$ América Latina, ainda hoje, é dado caracterizar a resistência do Estado às pressões favoráveis ao aborto: definido, de um modo geral, como crime. A ilegalidade é dado marcante. Reflete o fato, em boa parte, nossa formação histórica, que, por largo tempo, na Colônia e no feudalismo crioulo que a seguiu, alimentou, exaltou e insuflou exploratoriamente o machismo natalista. Era imperioso estimulá-lo, fazendo-o fulcro intocável do ideal masculino. Dessa forma, se proviam as forças econômicas de recursos imprescindíveis ao enriquecimento de quantos eram os poucos beneficiários de uma ordem social injusta, pois elitista, de exploração. - A escravatura ilustrou fartamente esse cuidado na produção de braços grátis ou quase a favor da aristocracia rural mais reacionária que jamais se terá conhecido. Destinada a mulher a parir e a cuidar dos filhos, em que - et pour cause - se exaltavam suas "irrenunciáveis virtudes e seu inviolável dever" - algum dia deveria buscar alforriar-se desse regime. Hoje a lei que lhe proíbe drasticamente o aborto não consegue evitar efeito contrário: impele-a à clandestinidade, que constitui mal social de alentadas proporções. Muitos vêem no fato reflexo da hipocrisia social. Não se pode esconder que os abortos de baixo custo, de que se socorrem pobres mães desassistidas, é um desastre.

O problema é alarmante". 
Nesses termos, é possível compreender a multiplicidade de abordagens possíveis em torno do tema, e os depoimentos continuam.

Dr. Jorge Andalaft Neto, especialista em saúde reprodutiva, destaca a importância da educação em direitos reprodutivos, citando experiências de outros países que criaram leis permissivas com resultados positivos.

Na sequência, Dra. Maria José Araújo, especialista em saúde da mulher, trata da segurança conferida ao procedimento quando o aborto é legalizado: quando você tem um país que o aborto é possível, que as mulheres podem fazer isso no serviço público ou no serviço privado, mas como um ato possível, adequado, com anestesia, em condições, sem ter aquela sensação de que a polícia pode entrar a qualquer momento, que você pode ser presa, que sua acompanhante pode ser presa, eu acho que muda bastante (...) diminui o risco, diminui a culpabilização ${ }^{580}$.

Há em destaque não só a possibilidade de acabar com o aborto clandestino, praticado de modo inseguro, como também os reflexos psicológicos, ao menos no que concerne à mitigação do medo que acompanha muitas vezes as práticas ilegais.

Por fim, temos as opiniões do Dr. Aníbal Faúndes, professor de Obstetrícia da Unicamp, que considera o aborto, em termos amplos, um verdadeiro malogro. De acordo com o professor, é um fracasso na sociedade, que não deu condições para que a mulher pudesse prevenir a gravidez, que não deu educação, que não deu anticoncepcional, que não deu um monte de coisas. É um fracasso individual da mulher que engravidou quando não deveria ter engravidado. E conclui: $O$ fundamental é que não adianta você condenar a mulher que faz o aborto. É injusto (...), é ineficaz e tem consequências graves para a mulher, para a sociedade.

Pelo exposto, $O$ aborto dos outros pode ser tomado como um documentário que retrata, de modo amplo, algumas motivações que ensejam o abortamento, seja legal, seja clandestino. Quanto à primeira modalidade, o aborto legal, é interessante o enfoque da diretora. Deveras, quando se discute o aborto, o aspecto antijurídico parece ganhar destaque. Mostrar abortos realizados sob o manto da legalidade, com segurança, por

\footnotetext{
${ }^{580}$ Ibid., pp. 55-74. Consultar, nesse sentido, os sistemas relacionados ao aborto trazidos pelo autor. Seria um empreendimento interessante listar a situação legal do aborto em cada país. Contudo, é tarefa mais pertinente para um estudo próprio. Para os fins desta pesquisa, é necessário salientar que em alguns países, como nos Estados Unidos, não há uma lei única, havendo grande autonomia para que cada estado legisle sobre o assunto. É o que se verifica no site: http://www.ncsl.org/default.aspx?tabid=14401, Acesso em: 9 de julho de 2011. Outros, como a Itália, admitem a realização do aborto, mas especificam a sua possibilidade durante o primeiro trimestre da gestação, condicionando-o, como ficou estabelecido a partir da Lei $n^{\circ}$ 194/1978. Consultar: http://www.columbia.edu/itc/history/degrazia/courseworks/legge_194.pdf, Acesso em 9 de julho de 2011.
} 
profissionais habilitados que perquirem as razões da interrupção da gravidez, com equipe multidisciplinar é algo que pouco se vê. A clandestinidade, por seu turno, é retratada de modo paralelo, o que propicia, por meio do contraste entre as duas realidades, uma profícua reflexão por comparação. 


\section{CONCLUSÃO}

Os debates bioéticos sempre se apresentam abertos a novas abordagens, o que revela a estrutura dialógica que compõe o cerne das questões que lhes são inerentes. Ao mesmo tempo, velhos temas ganham novas composições de acordo com as aspirações de determinada sociedade ou com os valores que se apresentam como dominantes em algum contexto.

Como pôde ser verificado na eleição presidencial de 2010, o tema do aborto voltou ao cume de destaque, mobilizando diferentes estratos sociais; a defesa da vida ganhou tônica nos argumentos antiaborto, como uma espécie de absolutismo moral. É o que se verifica no "Apelo a Todos os Brasileiros e Brasileiras", lançado no $2^{\circ}$ Encontro das Comissões Diocesanas em Defesa da Vida (CDDVs), organizado pela Comissão em Defesa da Vida da Regional Sul 1 da CNBB, que tanta polêmica causou, até mesmo dentro da própria Igreja.

A dignidade da vida sobrepõe-se, e qualquer outra escolha parece maculada com a pecha do aviltamento à existência humana. Por outro lado, quando se considera a pessoa como conceito filosófico, vimos, abre-se a possibilidade de uma decisão que não será condicionada de antemão a uma só escolha (defesa de uma vida incipiente), sem que sejam sopesadas as inúmeras facetas do aborto, as diversas questões que estão na órbita desse problema. Somente a pessoa pode ser considerada um sujeito moral, devendo o conceito de pessoa ser apartado, pois, da noção de organismo biológico. Também o feto, ainda que pese pertencer à espécie Homo sapiens, não pode ser considerado um sujeito moral nos termos definidos acima.

Ademais, pudemos afirmar com base nisso que essa ideia coaduna-se com o relativismo moral, já que respeita inúmeras necessidades e crenças. Para o Direito, deve centrar-se a preocupação com a pessoa humana. A Constituição Federal destaca em seu artigo $1^{\circ}$, inciso III não propriamente a dignidade da vida humana, mas da pessoa.

Assim, é necessária uma redefinição dos termos em que se verificam os debates sobre o aborto, erigindo a pessoa como núcleo das discussões e como critério a ser considerado também nos debates, com realce aos sujeitos morais em questão, sem o apego e adoração à vida humana. Dessa maneira, faz-se possível um discurso dialético, voltado ao diálogo, que mais importa num Estado verdadeiramente democrático e laico.

E a Arte - com destaque que damos ao Cinema - é forma de linguagem pródiga para aproximação entre afetividade e racionalidade, tão presentes nas decisões 
concernentes ao aborto. Pela sua perspectiva logopática, expande o universo do conhecimento, possibilitando a percepção de nuances antes ignoradas. Nessa empreitada interdisciplinar, sobreleva a dialogicidade do discurso, da conversa, das visões morais.

Numa sociedade plural, em que inúmeros valores convivem e se misturam, é estranho estabelecer como correto somente o posicionamento em que a proteção à vida humana vigora primordialmente, sem ao menos refletir sobre as inúmeras peculiaridades que cada caso envolve, os conflitos emocionais, os sentimentos presentes em cada um.

A vida, como dogma de fé, assenta-se numa moral que pretende estabelecer-se de modo absoluto, como a Moral. Porém, mesmo que reconheçamos numa sociedade valores dominantes em determinada época, isto não pode significar que sejam universais e totais dessa sociedade plural.

$\mathrm{O}$ apego à vida em sentido estritamente biológico ignora a morbidade alarmante atinente à clandestinidade abortiva, que quase sempre se relaciona à precariedade de condições, a um ocultamento de práticas que fazem parte da sociedade há muito tempo. $\mathrm{O}$ abortamento velado esconde mais do que a interrupção da gravidez; oculta problemas sociais sérios que estão na base das decisões e que não são levados em consideração, haja vista a cifra negra e a imprecisão dos dados relacionados ao assunto. Isso significa, sem qualquer dúvida, um desprezo pela vida que compõe os discursos fervorosos daqueles que ditam os dogmas.

O conceito de pessoa moral é passível de crítica, é bem verdade. No entanto, também o são o próprio sentido que se atribui às definições sobre o que seja a vida ou mesmo as tentativas de delimitar um momento para seu início. Tanto é que, além das definições tradicionais sobre o significado da vida, encontramos algumas elaborações que a tomam como sistema autopoiético ou como um fenômeno biossemiótico. Ou seja, a vida se escreve conforme a pena de quem a vê, conforme os fenômenos físicos ou existenciais são interpretados. Não há realidade sem interpretação por um sujeito.

Entendemos que, no universo do Direito, não é suficiente a individualidade genética: importa em primazia, como sujeito de relações, a pessoa. E um preceito fundamental desse conceito é a autoconsciência, que inexiste em fetos e embriões.

Como destaca Batista Mondin, “o homem não é uma ilha dispersa no oceano, nem uma mônada, fechada em si mesma, mas, um ser coexistente e comunicante, um ser excêntrico e dotado de uma abertura infinita, graças à qual se move constantemente" ${ }^{\text {"581. }}$.

\footnotetext{
${ }^{581}$ MONDIN, Battista. Definição filosófica de pessoa. Bauru: Edusc, 1998, p. 8.
} 
Não se trata de, com base no conceito de pessoa, estabelecer uma forma de manipulação que pode ser tão perniciosa e totalitária quanto a fundada numa visão sacramental da vida, mas, acima de tudo, possibilitar o diálogo entre todos os entendimentos sociais. Espera-se chegar a uma solução possível - entre várias -, num caso concreto, que leve em consideração todos os fatores envolvidos e não predetermine, com base em um apenas um sentido absoluto como correto.

A pessoa moral, como critério, deve somar-se ao debate plural, sem que seja em si um conceito que substitua a sacralidade da vida - o que seria o reverso da mesma moeda. 


\section{BIBLIOGRAFIA}

ALMEIDA, Silmara J. A. Chinelato e. Tutela civil do nascituro. São Paulo: Saraiva, 2000 .

ALVES, Alaôr Caffé. Lógica: pensamento formal e argumentação. São Paulo: Quartier Latin, 2005.

ANDORNO, Roberto. La distinction juridique entre les personnes et les choses à l'épreuve des procréations artificielles. Paris: L.G.D.J, t. 263, 1996.

AQUINO, Tomás de. Suma teológica. São Paulo: Loyola, volume I, 2001.

BADINTER, Elisabeth. Um amor conquistado: o mito do amor materno. Disponível em: http://www.fiocruz.br/redeblh/media/livrodigital\%20(pdf)\%20(rev).pdf (Acesso em 26 de agosto de 2011).

BACHA, Ângela Maria; GRASSIOTTO, Oswaldo da Rocha. Aspectos éticos das práticas abortivas. Bioética, v.2, nº 1, 1994.

BAKER, Lynne Rudder. When does a person begin? Disponível em: http://people.umass.edu/lrb/files/bak05wheaP.pdf, Acesso em: 18 de junho de 2011.

BALACS, Bela. Nós estamos no filme. In: XAVIER, Ismail (org). A experiência do cinema. Rio de Janeiro: Edições Gerais Graal, 1983.

BEAUCHAMP, Tom L.; CHILDRESS, James F. Principles of biomedical ethics. Oxford University Press: Oxford, 2001.

BENTHAM, Jeremy. Introdução aos princípios da moral e da legislação: sistema de logica dedutiva e indutiva e outros textos. São Paulo: Abril Cultural, 1984.

BERNADET, Jean-Claude. O que é cinema. São Paulo: Editora brasiliense, 2006. 
BESIO R. Mauricio. Inicio de la vida humana: la necesidad de una reflexión filosófica. Rev. Med. Chile, nº 125, 1997.

BITTAR, Eduardo C. B. O Direito na pós-modernidade. Rio de Janeiro: Forense Universitária, 2009.

BOBBIO, Norberto. A era dos direitos. Rio de Janeiro, Elsevier, 1992.

BONNICKSEN, Andrea L. The embryo as patient. In: HUMBER, James M.; ALMEDER, Robert F. (Ed.) Bioethics and the fetus: medical, moral, and legal issues. Totowa, N.J.: Humana Press, 1991.

BOONIN, David. A Defense of abortion. Cambridge: Cambridge University Press, 2003.

BRUNO, Zenilda Vieira. Abortamento na adolescência. In: CAVALCANTE, Alcilene; XAVIER, Dulce (org). Em defesa da vida: aborto e direitos humanos. São Paulo: Católicas pelo Direito de Decidir, 2006.

CABRERA, Júlio. O cinema pensa: uma introdução à Filosofia através dos filmes. Rio de Janeiro: Rocco, 2006.

CAMPOS, Arminda Eugênia Marques; BARTHOLO Jr, Roberto S. O que é um intelectual? In: BURSZTYN, Marcel (org.). Ciência, Ética e Sustentabilidade: desafios ao novo século. São Paulo: Cortez, 2001.

CANNETI, Elias. Massa e poder. São Paulo: Companhia das Letras, 1995.

CÁRCOVA, Carlo María. Derecho y Narración. In: TRINDADE, André Karam; GUBERT, Roberta Magalhães; COPETTI NETO, Alfredo (org). Direito \& Literatura: ensaios críticos. Porto Alegre: Livraria do Advogado, 2008.

CHORÃO, Mario Emílio Bigotte. Concepção realista da personalidade jurídica e estatuto do nascituro. Revista brasileira de Direito Comparado, n. 17, 1999. 
COHEN, Cláudio; SEGRE, Marco. Definição de valores, moral eticidade e ética. In: COHEN, Cláudio. Bioética, São Paulo: Edusp, 1999.

; FERRAZ, Flávio Carvalho. Direitos humanos ou ética das relações. In: COHEN,

Cláudio. Bioética, São Paulo: Edusp, 1999.

COMPARATO, Fábio Konder. A afirmação histórica dos direitos humanos. São Paulo: Saraiva, 2001.

Ética: Direito, Moral e Religião no mundo moderno. São Paulo:

Companhia das Letras, 2006.

. Fundamento dos direitos humanos. Revista do Instituto de Estudos

Avançados da Universidade de São Paulo, p. 12. Disponível em: http://www.iea.usp.br/textos/comparatodireitoshumanos.pdfv (Acesso em fevereiro de 2009)

COPI, Irving M. Introducción a la lógica. Buenos Aires: Editorial Universitária de Buenos Aires, 1962.

D’Agostino, Francesco. Bioética segundo o enfoque da Filosofia do Direito. São Leopoldo: Unisinos, 2006.

DARWIN, Charles. A origem das espécies. Folha de São Paulo, 2010.

DWORKIN, Ronald. Domínio da vida: aborto, eutanásia e liberdades individuais. São Paulo: Martins Fontes, 2003.

EL-HANI, Charbel Nino; EMMECHE, Claus. Definindo vida. In: EL-HANI, Charbel Nino; VIDEIRA, Antonio Augusto Passos (Orgs.). O que é vida?: para entender a Biologia do século XXI. Rio de Janeiro: Relume Dumará, 2000.

ENGELHARDT Jr., H. Tristam. Fundamentos da bioética. São Paulo: Loyola, 2004. 
EVNINE, Simon J. Epistemic dimensions of personhood. Nova York: Oxford University Press, 2008.

FAZENDA, Ivani C. Arantes. Interdisciplinaridade: história, teoria e pesquisa. Campinas: Papirus, 2010.

FERRAZ Jr., Tércio Sampaio. Teoria da norma jurídica. Rio de Janeiro: Forense, 1978. . O justo e o belo: notas sobre o direito e a arte, o senso de justiça e o gosto artístico. In: Estudos de Dilosofia do Direito: reflexões sobre o poder, a liberdade, a justiça e o Direito. São Paulo: Atlas, 2009.

Introdução ao estudo do Direito: técnica, decisão, dominação. São Paulo: Atlas, 1994.

A ciência do Direito. São Paulo: Atlas, 2006.

FLETCHER, Joseph. Humanhood: essays in biomedical ethics. New York: Prometheus Books, 1979.

FINNIS, John. Natural law and natural rights. New York: Oxford, 1996.

FORD, Norman M. When did I begin?: conception of the human individual in history, philosophy and science. Cambridge: Cambridge University, 1988.

_ The prenatal person: ethics from conception to birth. Reino Unido: Blackell, 2002.

HARMAN, Gilbert. THOMSON, Judith Jarvis. Moral relativism and moral objectivity. Oxford: Blackwell, 2003.

HART, Herbert L. A. O conceito de Direito. Lisboa: Fundação Lacouste Gulbenkian, 2007. 
JAEGER, Werner. Paideia: a formação do homem grego. São Paulo: Martins Fontes, 2010.

JAPIASSU, Hilton. Interdisciplinaridade e patologia do saber. Rio de Janeiro: Imago, 1976.

A crise da razão e do saber objetivo: as ondas do irracional. São Paulo: Letras \& Letras, 1996.

As paixões da ciência: estudos de história das ciências. São Paulo: Letras \& Letras, 1991.

Desistir do pensar? Nem pensar!:criando o sentido da vida num mundo funcional e instrumental. São Paulo: Letras\&Letras, 2001.

O sonho transdisciplinar e as razões da Filosofia. Rio de Janeiro: Imago, 2006.

KANT, Immanuel. Fundamentação da Metafísica dos costumes. São Paulo: Nacional, 1964.

KELSEN, Hans. Teoria Pura do Direito. São Paulo: Martins Fontes, 2009.

LARENZ, Karl. Metodologia da Ciência do Direito. Lisboa: Fundação Calouste Gulbenkian, 1997.

LEE, Patrick; GEORGE, Robert P. Body-Self dualism in contemporary ethics and politics. New York: Cambridge University Press, 2009.

LISPECTOR, Clarice. A hora da estrela. Rio de Janeiro: Rocco, 1998 A paixão segundo G.H. Rio de Janeiro: José Olympio, 1977. 
LOCKE, John. Ensayo sobre el entendimiento humano. Buenos Aires: Fondo de Cultura Económica, 1956.

LORAUX, Nicole. A tragédia grega e o humano. In: NOVAES, Adauto (org.). Ética: vários autores. São Paulo: Companhia das Letras, 2007.

MACEDO Jr., Ronaldo Porto. Kant e a crítica da razão: Moral e Direito. In: (coord).

Curso de Filosofia Política: do nascimento da Filosofia a Kant. São Paulo: Atlas, 2008.

MATURANA, Humberto R.; VARELA, Francisco R. A árvore do conhecimento: as bases biológicas da compreensão humana. São Paulo: Palas Athena, 2001.

MAUERHOFER, Hugo. A Psicologia da experiência cinematográfica. In: XAVIER, Ismail (org). A experiência do cinema. Rio de Janeiro: Edições Gerais Graal: Embrafilmes, 1983.

MCMAHAN, Jeff. A ética no ato de matar. Porto Alegre: Artmed, 2011.

MONDIN, Battista. Definição filosófica de pessoa. Bauru: Edusc, 1998.

MOORE, Keith; PERSAUD T. V. Embriologia clínica. Rio de Janeiro: Elsevier, 2008.

MORAES, Walter. Concepção tomista de pessoa: um contributo para a Teoria do Direito da personalidade. Revista de Direito Privado, nº 2, 2000.

MORIN, Edgar. A alma do cinema, In: XAVIER, Ismail (org). A experiência do cinema. Rio de Janeiro: Edições Gerais Graal: Embrafilmes, 1983.

. O método 5: a humanidade da humanidade. Porto Alegre: Sulina, 2007.

A cabeça bem-feita: repensar a reforma, reformar o pensamento. Rio de Janeiro: Bertrand Brasil, 2000. 
MUSTENBERG, Hugo. As emoções, In: XAVIER, Ismail (org). A experiência do cinema. Rio de Janeiro: Edições Gerais Graal: Embrafilmes, 1983.

NIETZSCHE, Friedrich. A genealogia da Moral. Petrópolis: Vozes, 2009.

NINO, Carlos Santiago. Ética y derechos humanos: un ensayo de fundamentación. Buenos Aires: Editorial Ástrea, 2007.

OLIVEIRA, Mara Regina de. Cinema e Filosofia do Direito: um estudo sobre a crise de legitimidade jurídica brasileira. Rio de Janeiro: Corifeu, 2006.

O Mercador de Veneza e o problema da justiça. Revista brasileira de Filosofia, $n^{\circ} 232,2009$.

O desafio à autoridade da lei: a relação existente entre poder, obediência e subversão. Rio de Janeiro: Corifeu, 2006.

ORTEGA Y GASSET, José. A rebelião das massas. São Paulo: Martins Fontes, 2007.

PAPALEO, Celso Cezar. Aborto e contracepção: atualidade e complexidade da questão. Rio de Janeiro: Renovar, 2000.

PEIRCE, Charles Sanders. Semiótica. São Paulo: Perspectiva, 1977.

PERELMAN, Chaïm. Ética e Direito. São Paulo: Martins Fontes, 2005.

PIOVESAN, Flávia. Direitos humanos e o Direito Constitucional Internacional. São Paulo: Saraiva, 2009.

PRADO, Lídia Reis de Almeida. O juiz e a emoção: aspectos da lógica da decisão judicial. Campinas: Millennium, 2008.

RAFFLER-ENGEL, Walburga von. The perception of the unborn across the cultures of the world. Hogrefe \&Huber, 1994. 
REALE, Miguel. Filosofia do Direito. São Paulo: Saraiva, 1982.

RICH, Ben A. Postmodern personhood: a matter of consciousness. Bioethics, v. 11, n. 3, 1997.

ROSADO-NUNES, Maria José. Aborto, maternidade e a dignidade da vida das mulheres. In: CAVAlCANTE, Alcilene; XAVIER, Dulce. (Org). Em defesa da vida: aborto e direitos humanos. São Paulo: Católicas pelo direito de decidir, 2006.

ROTHMAN, Bárbara Katz. Prenatal Diagnosis. In: HUMBER, James M.; ALMEDER, Robert F. (Ed.) Bioethics and the fetus: medical, moral, and legal issues. Totowa, N.J.: Humana Press, 1991.

. Recreating motherhood. New York: Rutgers, 2000.

SARMENTO, Daniel. Legalização do aborto e constituição. In CAVALCANTE, Alcilene; XAVIER; Dulce (org). Em defesa da vida: aborto e direito humanos. São Paulo: Católicas pelo Direito de Decidir, 2006.

SCHLOSSBERBER, Eugene. Moral responsibility and persons. Philadelphia: Temple University Press, 1992.

SEGRE, Marco. A propósito da utilização das células-tronco embrionárias. Estudos Avançados, v. 18, n. 51, 2004.

Limites éticos da intervenção sobre o ser humano. In: COHEN, Cláudio (Org.). Bioética. São Paulo: Edusp, 1999.

SHANNON, Thomas A. The moral significance of brain integration in the fetus. In: HUMBER, James M.; ALMEDER, Robert. F. Bioethics and the fetus. Totowa: The Humana Press, 1991.

SINGER, Peter. Libertação animal. São Paulo: Lugano, 2004. 
Ethics and disability. Disponível em <http://www.utilitarian.net/>. (Acesso em junho de 2009).

. Ética prática. São Paulo: Martins Fontes, 2002.

Rethinking life and death: the collapse of our traditional ethics. New York: St. Martin's Griftin, 1994.

Unsanctifying human life. Oxford: Blackwell publishers, 2002.

The sanctity of life. Foreign Policy, September/October 2005.

TELLES JUNIOR, Goffredo. Direito Quântico. São Paulo: Max Limonad, [19--].

. Estudos. São Paulo: Huarez de Oliveira, 2005.

TOOLEY, Michael; WOLF-DEVINE, Célia; DEVINE, Philip E.; JAGGAR, Alison M. Abortion: three perspectives. New York: Oxford University Press, 2009.

Aborto e infanticídio. In: GALVÃO, Pedro. A ética do aborto: perspectivas e argumentos. Lisboa: Dinalivro, 2005.

VERNANT, Jean Pierre. O universo, os deuses, os homens. São Paulo: Companhia das Letras, 2000.

YORK, Jon. The right to life and the value of life: orientations in law, politics and ethics. Great Britain: Ashgate, 2010.

ZEGERS H. Fernando. Reflexiones sobre los inicios del individuo humano. Rev. Med. Chile, $n^{\circ}$ 125, 1997.

ZOJA, Luigi. História da arrogância: Psicologia e limites do desenvolvimento humano. São Paulo: Axis Mundi, 2000. 


\section{Filmes e documentários}

O segredo de Vera Drake. Mike Leigh. Inglaterra, 2004. DVD.

4 meses, 3 semanas e 2 dias (4 luni, 3 saptamâni si 2 zile). Cristian Mungiu. Romênia, 2007. DVD.

O aborto dos outros. Carla Gallo. Brasil. DVD.

O grito silencioso (The Silent Scream).Bernard Nathanson.Estados Unidos. DVD.

Regras da vida (The Cider House Rules). Lasse Hallström. Estados Unidos. DVD.

\section{Endereços eletrônicos indicados ou acessados}

http://www.iea.usp.br/textos/comparatodireitoshumanos.pdfv

http://www.utilitarian.net/

http://www.ibdfam.org.br/?artigos\&artigo $=732$

www.pge.sp.gov.br/centrodeestudos/bibliotecavirtual/instrumentos/viena.htm

http://www.4months3weeksand2days.com/blog/notes-from-the-director/

www.internationalrigthtolife.com

www.spuc.org.uk

www.prolifeamerica.com

www.prochoicemajority.org.uk 
http://www.utilitarian.net/singer/by/200509--.htm

http://www.oabortodosoutros.com.br/index_pt.html

http://www.ncsl.org/default.aspx?tabid=14401

http://www.columbia.edu/itc/history/degrazia/courseworks/legge 194.pdf

http://www.fiocruz.br/redeblh/media/livrodigital\%20(pdf)\%20(rev).pdf 